Estudio de proteínas que unen ácidos grasos (FABPs) de Echinococcus spp.

Lic. Jorge Luis Pórfido

Directora: Dra. Betina Córsico

Codirectora: Dra. Adriana Esteves

Universidad Nacional de La Plata Facultad de Ciencias Exactas 


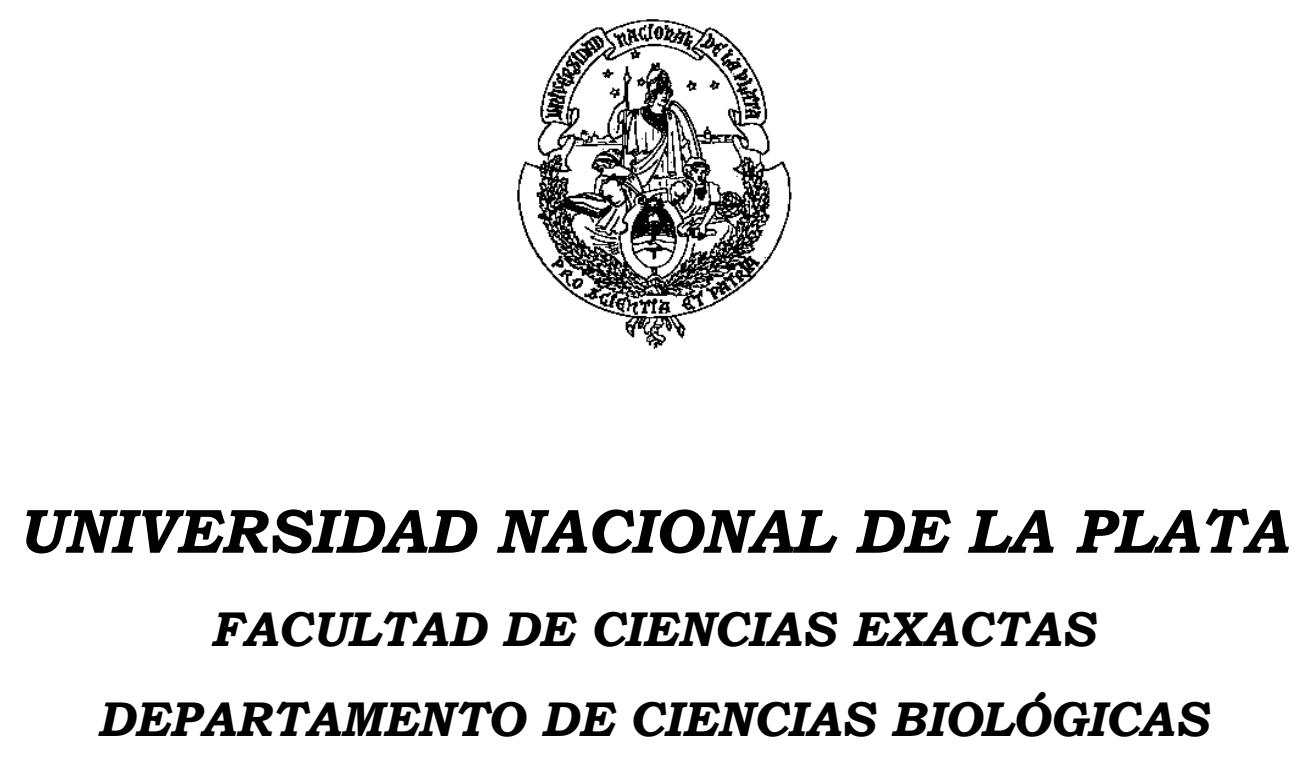

Trabajo de Tesis Doctoral

\title{
Estudio de proteínas que unen ácidos grasos (FABPs) de Echinococcus spp.
}

\author{
Jorge Luis Pórfido \\ Directora: Dra. Betina Córsico \\ Co-directora: Dra. Adriana Esteves
}


El presente trabajo de tesis, que lleva por título "Estudio de proteínas que unen ácidos grasos (FABPs) de Echinococcus spp.", se realizó para optar al grado académico de Doctor de la Facultad de Ciencias Exactas (Área Ciencias Biológicas) de la Universidad Nacional de La Plata (UNLP).

El mismo se llevó a cabo en el Instituto de Investigaciones Bioquímicas de La Plata (INIBIOLP), instituto que pertenece a la UNLP y al Consejo Nacional de Investigaciones Científicas y Técnicas (CONICET), ubicado en la Facultad de Ciencias Médicas (UNLP). También se realizó una estadía de tres meses en el Instituto de Higiene y Microbiología de la Universidad de Wurzburgo (Alemania).

Este trabajo contó con la dirección de la Dra. Betina Córsico (Investigadora Independiente, CONICET; Prof. Titular, Departamento Ciencias Biológicas, Facultad de Ciencias Exactas, UNLP, Argentina) y la co-dirección de la Dra. Adriana Esteves (Prof. Adjunta, Sección Bioquímica, Facultad de Ciencias, UdelaR, Uruguay).

Para su realización se recibió el apoyo financiero del CONICET mediante las Becas Internas de Posgrado Tipo I (2009-2012) y Tipo II (2012-2014), y del Departamento de Ciencias Biológicas de la Facultad de Ciencias Exactas de la UNLP a través del Programa de Retención de Recursos Humanos (2014-2015). Por otra parte, la estadía en la Universidad de Wurzburgo fue financiada mediante una beca EMBO Short Term Fellowship de la Organización Europea de Biología Molecular (EMBO). El trabajo experimental se llevó a cabo mediante financiación de la organización Wellcome Trust (WT Nº83625, Reino Unido), de la Agencia Nacional de Promoción Científica y Tecnológica (PICT N²010/2252, Argentina) y de la UNLP (Proyecto Acreditado M152). 


\section{AGRADECIMIENTOS}

A Betina, por todo lo aprendido junto a ella durante todo este tiempo. Por haberme sumado al equipo del Laboratorio 10, del que espero seguir siendo parte aun cuando mi camino tome otro rumbo. Por todos los buenos momentos compartidos. Por las dificultades que hemos podido superar juntos, que siempre nos han dejado alguna enseñanza. Por haber depositado en mí su confianza.

A Adriana, por compartir conmigo la posibilidad de estudiar el complejo e interesante mundo de las FABPs de Echinococcus.

A todos mis compañeros y amigos del $L a b 10$, con los que he compartido todos estos años. Por su compañerismo y disposición para trabajar en equipo. Por crear un buen ambiente de trabajo, aun cuando el espacio escaseara. Por aprender juntos a disfrutar los buenos momentos, y a tirar todos para un mismo lado cuando las situaciones así lo requirieran. A Gise, por su invaluable apoyo durante mi doctorado. Por haber sido una excelente guía en el trabajo y la vida diaria del laboratorio. Por su inmensa generosidad. Por su predisposición incondicional para ayudarme en lo que necesitara. $Y$ obviamente, por todas sus ocurrencias que me han hecho reír mucho. A Lisandro, que me acercó al Lab 10, por sus sugerencias y observaciones, por tener siempre presente todas las posibilidades de becas, cursos, congresos y oportunidades para cada uno de nosotros. A Edu, que me ayudó a dar mis primeros pasos en la biología molecular, y que ilustró nuestros días con sus dibujos y caricaturas, siempre cargadas de muy buen humor. A Xime, por sus enseñanzas al comienzo de mi doctorado. A Mari y Flor, por tantos momentos compartidos junto a ellas. Por haber ido descubriendo juntos el complejo mundo de la parasitología, y ayudándonos mutuamente a superar los obstáculos que se nos fueran presentando. A Lu, por todas las aventuras compartidas. Por sus ocurrencias y anécdotas diarias, por haber ido creciendo juntos en la facultad, en el laboratorio, en la docencia. A Nati B., por su excelente predisposición para colaborar en todo, por su frescura y buen humor, por sus miradas cómplices y gestos divertidos. A Nati S., por compartir su experiencia conmigo y haberme ayudado a no bajar los brazos durante la etapa de escritura de la tesis. A Juli, con quien compartí mis últimos tiempos de trabajo experimental, y que continuará con parte del trabajo relacionado con las FABPs de Echinococcus, por su buena onda y compañerismo. A las nuevas generaciones que se han incorporado al laboratorio y con los cuales he compartido las últimas etapas de mi tesis. 
A la gente del INIBIOLP, por su apoyo y compañerismo. En especial a Annie, Juan Pablo, Martín, Lucía, Margarita, Boris, Nela y Sandra, con quienes he compartido buenos momentos, dentro y fuera del laboratorio. A Martín le agradezco también su ayuda con el trabajo con lípidos y a Juan Pablo su colaboración con el tema de lípidos y de las imágenes de microscopía. A Mabel y Ana Laura, por su ayuda y buena predisposición. A Mario, por su voluntad para ayudar en todo lo que hiciera falta, y por las excelentes figuras que ha hecho tanto para la tesis como para los capítulos del libro.

A la Dra. Gabriela Alvite, con quien compartí el estudio de EgFABP1.

Al Dr. Klaus Brehm y la gente de su laboratorio, por haberme dado la posibilidad de ir a trabajar y aprender con ellos. Especialmente a Uriel, Ferenc y Monika, que me ayudaron mucho durante mi estadía allí.

A la Dra. Mara Rosenzvit y sus estudiantes, que me han guiado en muchos aspectos relacionados con Echinococcus spp. Muy especialmente a Marce, con quien compartí también parte de mi estadía en Alemania, a Fede, a Lucas y a Laura K.

A la Dra. Ana María Ferreira, por las valiosas charlas que hemos compartido. Por su calidez y generosidad. A la gente de su laboratorio. En especial a María y Maite, por su buena onda y humor. A Maite también le agradezco el haber compartido conmigo sus datos de proteómica de Echinococcus

A los Dres. Malcolm W. Kennedy y Alan Cooper, por su colaboración con el análisis de los experimentos de unión a ligandos y sus valiosas sugerencias.

Al Dr. José María Delfino, por permitirnos acceder al equipo de dicroísmo circular.

A Agus y Nacho, por su ayuda con las carátulas aún después de un largo día de estudio.

A mis compañeros de docencia. A los de la cátedra de Biología, con quienes di mis primeros pasos, y a los de Bioquímica 2 y 3 , con quienes he compartido los últimos años. A todos muchas gracias por todo lo aprendido y los buenos momentos compartidos

A mis amigos. Por su apoyo y generosidad. Por acompañarme en las buenas y en las malas. Por saber perdonar que a veces sea un poco colgado. Por seguir creciendo juntos. A los Viejitos: Boris, Cin, Clari, Mancho, Mari, Mauri, Ro y Sabri. Por todas las aventuras compartidas. Por nuestras apasionadas discusiones que siempre terminan en risas. A Andre, por todos estos años compartidos. Por su confianza. Por ayudarme a seguir adelante.

A mis padres. Porque todo ha sido posible gracias a ellos. Por enseñarme a soñar y a seguir mis convicciones. Por mostrarme, con su ejemplo, que con esfuerzo y dedicación todo es posible. Por darme libertad para elegir, y la responsabilidad de hacerme cargo de mis elecciones. Por acompañarme en todo momento. 
A mis hermanos, Santi y Nacho. Porque son las personas con las que más he compartido mi vida. Por los años compartidos en La Plata. Por haberme aguantado y acompañado durante todos los vaivenes por los que he pasado. Por sus palabras de aliento. Por los consejos que cada uno, según su visión, me han dado. Por sus locuras y payasadas, que siempre logran hacerme reír sin importar cuánto intente mantener la compostura.

A mis abuelos y mi abuela honoraria, Tali. Por creer en mí y acompañarme siempre, los que están y los que ya no. Porque todo es más fácil cuando se está "sobre hombros de gigantes".

A Val. Por ser mi gran compañera, mi guía y mi sostén. Por ayudarme a no aflojar. Por su generosidad. Por elegir seguir transitando juntos el camino. Juntos, a la par.

A todos, ¡muchísimas gracias! 


\section{PUBLICACIONES DURANTE EL DESARROLLO DEL PRESENTE DOCTORADO}

Relacionadas con esta tesis:

Jorge L. Pórfido*, Gabriela Alvite*, Valeria Silva, Malcolm W. Kennedy, Adriana Esteves, Betina Corsico. Direct interaction between EgFABP1, a fatty acid binding protein from Echinococcus granulosus, and phospholipid membranes. PLoS Negl Trop Dis. 2012; 6(11): e1893.

Gisela Raquel Franchini, Betina Córsico, Jorge L. Pórfido, Valeria Silva, Marina Ibañez Shimabukuro, Florencia Rey Burusco. Análisis Estructural y Funcional de Proteínas Solubles que Unen Lípidos de Parásitos Helmintos. Acta Bioquím Clín Latinoam 2013; 47 (2).

Gisela Raquel Franchini; Jorge L. Pórfido; Marina Ibañez Shimabukuro; Maria F. Rey Burusco; Julián A. Bélgamo; Brian O. Smith; Malcolm W. Kennedy; Betina Córsico. The unusual lipid binding proteins of parasitic helminths and their potential roles in parasitism and as therapeutic targets. Prostaglandins Leukot Essent Fatty Acids. 2015; 93:31-6.

No presentadas en esta tesis:

Valeria Silva-Álvarez, Gisela R. Franchini, Jorge L. Pórfido, Malcolm W. Kennedy, Ana M. Ferreira, Betina Córsico. Lipid-free Antigen B Subunits from Echinococcus granulosus: Oligomerization, ligand binding, and membrane interaction properties. PLoS Negl Trop Dis. 2015; 9(3):e0003552.

Capítulos de Libros:

Valeria Silva, Jorge L. Pórfido. Interacción de lípidos con el agua y formación de estructuras empaquetadas. (2013). Análisis estructural y funcional de Macromoléculas. ISBN 978-950-34-1057-8. Capítulo 8. Pág.199-226. Ed. EDULP. Colección Libros de Cátedra, UNLP.

Jorge L. Pórfido, Valeria Silva. Interacción lípido-proteína. (2013). Análisis estructural y funcional de Macromoléculas. ISBN 978-950-34-1057-8. Capítulo 9. Pág. 227-258. Ed. EDULP. Colección Libros de Cátedra, UNLP. 


\section{INDICE GENERAL}

ABREVIATURAS 1

RESUMEN

1. INTRODUCCIÓN 6

1.1. Parasitismo 6

1.1.1. Clases de parásitos $\quad 6$

1.1.2. Características del parasitismo $\quad 7$

1.2. Cestodos 9

1.3. Género Echinococcus 11

1.3.1. Ciclo de vida de Echinococcus spp. 12

1.3.2. Especies pertenecientes al género Echinococcus 13

$\begin{array}{ll}\text { 1.3.3. Morfología de Echinococcus spp. } & 15\end{array}$

1.3.3.1. Adulto 16

$\begin{array}{ll}\text { 1.3.3.2. Huevo } & 18\end{array}$

1.3.3.3. Metacestodo 19

1.3.3.4. Protoescólex 22

1.3.4. Distribución geográfica de la hidatidosis 23

1.3.5. Importancia de la hidatidosis quística en nuestra región 25

1.3.6. Diagnóstico y tratamiento de la hidatidosis 28

1.4. Metabolismo de Echinococcus spp. y otros cestodos 30

1.4.1. Metabolismo general y obtención de energía 30

1.4.2. Metabolismo de lípidos $\quad 32$

1.5. Proteínas que unen ligandos hidrofóbicos (HLBPs) 34

1.6. Proteínas que unen ácidos grasos (FABPs) 37

$\begin{array}{ll}\text { 1.6.1. FABPs en invertebrados } & 42\end{array}$

1.6.1.1. FABPs en Echinococcus spp. 44

$\begin{array}{ll}\text { 1.7. Hipótesis y objetivos } & 47\end{array}$

$\begin{array}{ll}\text { 1.7.1. Hipótesis general } & 47\end{array}$

$\begin{array}{ll}\text { 1.7.2. Objetivo general } & 47\end{array}$

$\begin{array}{ll}\text { 1.7.3. Objetivos específicos } & 48\end{array}$

1.7.3.1. Subclonado y purificación de EgFABP1 48

1.7.3.2. Análisis de la interacción de EgFABP1 con ligandos 48

1.7.3.3. Análisis de la interacción de EgFABP1 con membranas 48

1.7.3.4. Identificación y análisis de FABPs de E. multilocularis $\quad 49$

2. MATERIALES Y MÉTODOS 50

2.1. Subclonado y purificación de EgFABP1 50

2.1.1. Subclonado de EgFABP1 50

2.1.1.1. Extracción y purificación de ADN plasmídico (miniprep) 50

2.1.1.2. Diseño de los primers específicos para EgFABP1 50

2.1.1.3. Reacción en cadena de la polimerasa ( $P C R)$ para amplificar la secuencia codificante del gen egfabp1 51

2.1.1.4. Digestión de ADN con enzimas de restricción 51

2.1.1.5. Electroforesis de ADN en geles de agarosa 52 
2.1.1.6. Purificación de fragmentos de ADN a partir de geles de agarosa

2.1.1.7. Desfosforilación de los extremos 5'

2.1.1.8. Ligación

2.1.1.9. Preparación de bacterias competentes

2.1.1.10. Transformación de bacterias competentes por shock térmico

2.1.2. Purificación de EgFABP1

2.1.2.1. Screening de expresión de proteínas recombinantes

2.1.2.2. Electroforesis desnaturalizante en geles de poliacrilamida (SDS-PAGE)

2.1.2.3. Expresión y Purificación de EgFABP1

2.1.2.4. Cuantificación de EgFABP1 purificada

2.1.3. Control de la integridad estructural de EgFABP1

2.1.3.1. Análisis por cromatografía de exclusión molecular

58

2.1.3.2. Análisis por dicroísmo circular

2.2. Análisis de la interacción de EgFABP1 con ligandos

2.2.1. Análisis de lípidos de Escherichia coli unidos a EgFABP1 recombinante

2.2.1.1. Extracción de los lípidos con solventes orgánicos

2.2.1.2. Cromatografía en capa fina

2.2.1.3. Cromatografía gas-líquido

2.2.2. Análisis de la interacción con ligandos por proteólisis parcial de EgFABP1

2.2.2.1. Digestión parcial de EgFABP1 empleando la proteasa ArgC

2.2.2.2. Análisis por electroforesis Tricina-SDS-PAGE

2.2.3. Análisis por dicroísmo circular de la interacción de EgFABP1 con ácidos grasos

2.2.4. Análisis de la interacción de EgFABP1 con análogos fluorescentes de ácidos grasos

2.3. Análisis de la interacción de EgFABP1 con membranas

2.3.1. Preparación de vesículas unilamelares pequeñas

2.3.2. Determinación del coeficiente de partición $\left(K_{P}\right)$ de $12 A S$ entre EgFABP1 y SUVs

2.3.3. Determinación de la velocidad de transferencia de $12 \mathrm{AS}$ desde EgFABP1 a SUVs

2.3.4. Determinación de la unión de EgFABP1 a SUVs por competencia con citocromo c

\subsection{Identificación y análisis de FABPs de E. multilocularis}

2.4.1. Análisis bioinformático del genoma de E. multilocularis

2.4.3. Obtención, aislamiento y cultivo de células de E. multilocularis

2.4.4. Electroporación de células de E. multilocularis

2.4.5. Monitoreo de los niveles de expresión de las FABPs de E. multilocularis 
2.4.5.2. SDS-PAGE/Western Blot $\quad 70$

2.4.5.3. Extracción de ARN $\quad 70$

2.4.5.4. Síntesis de cDNA $\quad 71$

2.4.5.5. RT-PCR semicuantitativa $\quad 72$

2.4.6. Clonado y caracterización de FABPs de E. multilocularis 72

2.4.6.1. Clonado de las secuencias codificantes de las diferentes EmFABPs

72

2.4.6.2. Caracterización bioinformática de las secuencias proteicas de las FABPs de E. multilocularis

2.4.6.3. Caracterización bioinformática de los genes de las FABPs de E. multilocularis

2.4.6.4. Predicción de FABPs en E. granulosus y comparación con las FABPs de E. multilocularis

2.4.6.5. Análisis de la expresión de FABPs en E. multilocularis $\quad 75$

\section{RESULTADOS}

\subsection{Subclonado y purificación de EgFABP1}

3.1.1. Subclonado de EgFABP1

76

3.1.2. Purificación de EgFABP1

76

3.1.3. Control de la integridad estructural de EgFABP1 85

3.2. Análisis de la interacción de EgFABP1 con ligandos

3.2.1. Análisis de lípidos de Escherichia coli unidos a EgFABP1 recombinante

3.2.2. Análisis de la interacción con ligandos por proteólisis parcial de EgFABP1

3.2.3. Análisis por dicroísmo circular de la interacción de EgFABP1 con ácidos grasos

3.2.4. Análisis de la interacción de EgFABP1 con análogos fluorescentes de ácidos grasos

3.3. Análisis de la interacción de EgFABP1 con membranas

3.3.1. Determinación del coeficiente de partición $\left(K_{P}\right)$ de $12 A S$ entre EgFABP1 y SUVs

3.3.2. Transferencia de análogos fluorescentes de ácidos grasos desde EgFABP1 hacia vesículas unilamelares pequeñas.

3.3.3. Determinación de la unión de EgFABP1 a SUVs por competencia con Citocromo c

3.4.1. Ensayos de silenciamiento en células de E. multilocularis

3.4.2.1. Clonado de las secuencias codificantes de las diferentes EmFABPs

3.4.2.2. Caracterización bioinformática de las secuencias proteicas de las FABPs de E. multilocularis

3.4.2.3. Caracterización bioinformática de los genes de las FABPs de E. multilocularis

3.4.2.4. Predicción de FABPs en E. granulosus y comparación con las FABPs de E. multilocularis 
3.4.2.5. Análisis de la expresión a nivel transcripcional de FABPs en E. multilocularis

4. DISCUSIÓN GENERAL

5. CONCLUSIONES

6. PERSPECTIVAS FUTURAS 139

7. APÉNDICES 140

7.1. Listado de primers y siRNAs $\quad 140$

$\begin{array}{lr}\text { 7.1.1. Primers } & 140\end{array}$

$\begin{array}{ll}\text { 7.1.2. SiRNAs } & 141\end{array}$

7.2. Plásmidos empleados 142

$\begin{array}{ll}\text { 7.3. Verificación de secuencias clonadas } & 145\end{array}$

7.3.1. Inserto de EgFABP1 subclonado en pET-11b 145

$\begin{array}{ll}\text { 7.3.2. EmFABPs clonadas en PGEM-T } & 146\end{array}$

7.4. Obtención y caracterización de anticuerpos policlonales $\boldsymbol{\alpha}$-EgFABP1 149

$\begin{array}{ll}\text { 7.4.1. Materiales y métodos empleados } & 149\end{array}$

7.4.1.1. Inmunización y obtención de los sueros 149

7.4.1.2. Determinación del título del antisuero por ELISA 149

7.4.1.3. Caracterización del antisuero por Western-Blot 150

$\begin{array}{ll}\text { 7.4.2. Resultados obtenidos } & 151\end{array}$

7.4.2.1. Caracterización de anticuerpos policlonales $\alpha$-EgFABP1 151

7.5. Inmunolocalización de FABPs en Echinococcus spp. 153

$\begin{array}{ll}\text { 7.5.1. Materiales y métodos empleados } & 153\end{array}$

7.5.1.1. Inmunofluorescencia en protoescólices in toto de E. granulosus

7.5.1.2. Inmunohistoquímica en cortes de vesículas de E. multilocularis obtenidas in vitro 154

$\begin{array}{ll}\text { 7.5.2. Resultados obtenidos } & 155\end{array}$

7.5.2.1. Inmunofluorescencia en protoescólices in toto de E. granulosus

7.5.2.2. Inmunohistoquímica en cortes de vesículas de E. multilocularis obtenidas in vitro

8. BIBLIOGRAFÍA 


\section{INDICE DE TABLAS Y FIGURAS}

Tabla I-1. Taxonomía del género Echinococcus.

Tabla I-2. Nomenclatura y localización de las FABPs de humanos 39

Tabla R-1. Deslipidización de EgFABP1 82

Tabla R-2. Datos de las secuencias predichas para FABPs en E. multilocularis $\quad 108$

Tabla R-3. Análisis de identidad de secuencias entre las diversas FABPs de $E$. multilocularis

Tabla R-4. Comparación de secuencias de las FABPs de E. multilocularis con la base de datos de proteínas del NCBI

Tabla R-5. Comparación de secuencias de las FABPs de E. multilocularis con la base de datos de proteínas de mamíferos del NCBI

Tabla R-6. Posición y tamaño de los intrones en las diferentes EmFABPs

Tabla R-7. Datos de las secuencias predichas para FABPs en E. granulosus

Tabla R-8. Análisis de identidad de secuencias entre las diversas FABPs de $E$. granulosus

Tabla R-9. Análisis de identidad de secuencias entre las FABPs de E. granulosus y E. multilocularis

Figura I-1. Esquema del tegumento de un cestodo adulto

Figura I-2. Esquema de los ciclos de vida de E. granulosus s.l. y E. multilocularis

Figura I-3. Adulto de E. granulosus

Figura I-4. Huevo de E. granulosus

Figura I-5. Esquema de la estructura del metacestodo

Figura I-6. Esquema de un protoescólex de E. granulosus 22

Figura I-7. Distribución geográfica de la hidatidosis quística y alveolar 24

Figura I-8. Principales focos de hidatidosis quística en Argentina 26

Figura I-9. Metabolismo lipídico en cestodos $\quad 34$

Figura I-10. Estructura terciaria de las FABPs $\quad 40$

Figura I-11. Posición de intrones en genes de FABPs 43

Figura I-12. Estructura terciaria de EgFABP1 46

Figura R-1. Control del inserto egfabp1 y el plásmido pET-11b digeridos.

Figura R-2. Screening por PCR de bacterias transformadas con plásmidos recombinantes.

Figura R-3. Chequeo de los plásmidos recombinantes por digestión con enzimas de restricción.

Figura R-4. Screening de expresión de EgFABP1

Figura R-5. Pasos de la purificación de EgFABP1

Figura R-6. Cromatograma correspondiente a la cromatografía de exclusión molecular.

Figura R-7. SDS-PAGE de las muestras colectadas de la cromatografía de exclusión molecular.

Figura R-8. Cromatograma correspondiente a la cromatografía de interacción hidrofóbica.

Figura R-9. SDS-PAGE de la muestra obtenida luego de la cromatografía de interacción hidrofóbica. 
Figura R-10. Cromatograma correspondiente a la cromatografía de intercambio iónico.

Figura R-11. Espectros de absorción de diferentes muestras de EgFABP1.

Figura R-12. Análisis por cromatografía de exclusión molecular de EgFABP1 purificada.

Figura R-13. Espectros de dicroísmo circular de EgFABP1.

Figura R-14. Análisis de lípidos de E. coli unidos a EgFABP1 recombinante

Figura R-15. Proteólisis parcial de EgFABP1 en sus formas apo- y unida a diferentes ligandos

Figura R-16. Espectros de dicroísmo circular de EgFABP1 en sus formas apo-y unida a diferentes ligandos

Figura R-17. Titulación fluorimétrica de 12AS con EgFABP1 93

Figura R18. Titulación fluorimétrica de 16AP con EgFABP1 94

Figura R-19. Titulación del complejo EgFABP1-12AS con SUVs de EPC/NBD-PC

Figura R-20. Efecto de la concentración de vesículas aceptoras sobre la velocidad de transferencia de 12AS desde EgFABP1 a SUVs de EPC/NBD-PC

Figura R-21. Efecto de la carga superficial de las vesículas aceptoras sobre la velocidad de transferencia de 12AS desde EgFABP1 a SUVs

Figura R-22. Efecto de la concentración de vesículas aceptoras sobre la velocidad de transferencia de 12AS desde EgFABP1 a SUVs con carga neta negativa

Figura R-23. Efecto de la fuerza iónica del buffer sobre la velocidad de transferencia de 12AS desde EgFABP1 a SUVs con carga neta negativa

Figura R-24. Inhibición de la unión de CitC a vesículas fosfolipídicas aniónicas

Figura R-25. Agregados de células primarias de E. multilocularis luego de 12 días en cultivo

Figura R-26. Western Blots contra Elp y FABPs en células de E. multilocularis tratadas con siRNAs

Figura R-27. Niveles de expresión relativa de FABPs en células de E. multilocularis tratadas con siRNAs

Figura R-28. RT-PCR en células electroporadas sin siRNAs y con siRNA a-FABP1

Figura R-29. Digestiones con EcoRI de los plásmidos pGEM-T recombinantes

Figura R-30. Análisis de los dominios de las FABPs predichas en E. multilocularis

Figura R-31. Predicción de la estructura secundaria de EmFABP1

Figura R-32. Predicción de la estructura secundaria de EmFABP2

Figura R-33. Predicción de la estructura secundaria de EmFABP3

Figura R-34. Predicción de la estructura secundaria de EmFABP5

Figura R-35. Predicción de la estructura secundaria de EmFABP4

Figura R-36. Alineamiento de las secuencias de las FABPs de E. multilocularis

Figura R-37. Alineamiento de las secuencias de EmFABP1 y EmFABP2

Figura R-38. Alineamiento de las secuencias de EmFABP1 y EmFABP2 con cada una de las demás FABPs

Figura R-39. Esquema de la posición y tamaño de los intrones en las secuencias de aminoácidos de las EmFABPs 
Figura R-40. Esquema de la posición de los genes emfabp1-4 en el cromosoma 7 de E. multilocularis

Figura R-41. Esquema de la posición del gen emfabp5 en el cromosoma 4 de

E. multilocularis

Figura R-42A. Alineamiento de las dos copias de EmFABP1 en el genoma de E. multilocularis

Figura R-42B. Alineamiento de las dos copias de EmFABP1 en el genoma de E. multilocularis

Figura R-43. Alineamiento de las secuencias proteicas de EgFABP1 y EgFABP1.2

Figura R-44. Comparación entre las secuencias proteicas de las EmFABPs y las EgFABPs

Figura R-45. Esquema de la posición de los genes emfabp2, emfabp1 y emfabp1.2 en el scaffold_007 de la versión "Egranulosus_genome_v3" del genoma de E. granulosus

Figura R-46. Comparación de la secuencia de EmFABP3 con la secuencia equivalente propuesta por $Y$. Zheng et al. (2013)

Figura R-47. Análisis de los dominios de la proteína Emul_FABP1 predicha por Y. Zheng et al. (2013)

Figura R-48. Análisis de la expresión relativa de diferentes EmFABPs en diferentes tejidos de E. multilocularis.

Figura A-1. Mapa del vector pET-5a

Figura A-2. Mapa del vector $p E T-11 a$

Figura A-3. Mapa del vector pGEM-T Easy

Figura A-4. Verificación de la secuencia del inserto EgFABP1 subclonado en el plásmido $\mathrm{pET}-11 \mathrm{~b}$

Figura A-5. Verificación de la secuencia del inserto EmFABP1 subclonado en el plásmido pGEM-T Easy

Figura A-6. Verificación de la secuencia del inserto EmFABP2 subclonado en el plásmido pGEM-T Easy

Figura A-7. Verificación de la secuencia del inserto EmFABP3 subclonado en el plásmido pGEM-T Easy

Figura A-8. Verificación de la secuencia del inserto EmFABP4 subclonado en el plásmido pGEM-T Easy

Figura A-9. Verificación de la secuencia del inserto EmFABP5 subclonado en el plásmido pGEM-T Easy

Figura A-10. Caracterización de los anticuerpos policlonales anti-EgFABP1 por Western Blot

Figura A-11. Western Blot de muestras de proteínas de E. multilocularis. 152

Figura A-12. Inmunofluorescencias in toto en protoescólices de E. granulosus. 155

Figura A-13. Imnunohistoquímica en cortes de vesículas de E. multilocularis obtenidas in vitro. 


\section{ABREVIATURAS}

\begin{tabular}{|c|c|}
\hline${ }^{\circ} \mathbf{C}$ & grado Celsius \\
\hline $12 \mathrm{AO}$ & ácido 12-(9-antroiloxi)-oleico \\
\hline 12AS & ácido 12-(9-antroiloxi)-esteárico \\
\hline 16AP & ácido 16-(9-antroiloxi)-palmítico \\
\hline 2AP & ácido 2-(9-antroiloxi)-palmítico \\
\hline AC & anhidrasa carbónica \\
\hline Acetil-CoA & acetil-coenzima A \\
\hline ADN & ácido desoxirribonucleico \\
\hline AEC & 3-amino-9-etilcarbazol \\
\hline AG & ácidos grasos \\
\hline AOFA & antroiloxi-ácidos grasos \\
\hline ARN & ácido ribonucleico \\
\hline ASCT & acetato:succinato CoA-transferasa \\
\hline ATP & adenosina trifosfato \\
\hline BSA & seroalbúmina bovina \\
\hline cDMEM & medio de cultivo Dulbecco's Modified Eagle's condicionado \\
\hline cDNA & ADN complementario al ARN mensajero \\
\hline CDS & secuencias codificantes (del inglés coding DNA sequences) \\
\hline CG & capa germinativa \\
\hline CIAP & $\begin{array}{l}\text { fosfatasa alcalina de intestino de ternero (del inglés calf intestine alkaline } \\
\text { phosphatase) }\end{array}$ \\
\hline CitC & citocromo c \\
\hline LL & capa laminar (del inglés laminated layer) \\
\hline CL & cardiolipina \\
\hline CRABPs & $\begin{array}{l}\text { proteínas celulares que unen ácido retinoico (del inglés cellular retinoic } \\
\text { acid binding proteins) }\end{array}$ \\
\hline CRBPs & $\begin{array}{l}\text { proteínas celulares que unen retinol (del inglés cellular retinol binding } \\
\text { proteins) }\end{array}$ \\
\hline DAPI & 4',6-diamidino-2-fenilindol \\
\hline DMSO & dimetilsulfóxido \\
\hline dNTPs & desoxirribonucleótidos trifosfato (dATP, dGTP, dCTP y dTTP) \\
\hline DO & densidad óptica \\
\hline DPE & dansil-fosfatidiletanolamina \\
\hline dpm & desintegraciones por minuto \\
\hline DTT & ditiotreitol \\
\hline EDTA & ácido etilendiaminotetraacético \\
\hline EgAgB & Antígeno B de Echinococcus granulosus \\
\hline ELISA & enzimoinmunoensayo (del inglés enzyme linked immuno sorbent assay) \\
\hline EPC & fosfatidilcolina de huevo \\
\hline EPE & fosfatidiletanolamina de huevo \\
\hline FABPs & proteínas que unen ácidos grasos (del inglés fatty acid binding proteins) \\
\hline FAMEs & ésteres metílicos de ácidos grasos (del inglés fatty acid methyl ester) \\
\hline FITC & isotiocianato de fluoresceína \\
\hline
\end{tabular}


FRET transferencia de energía de resonancia de Förster (del inglés Förster resonance energy transfer)

Fw primer directo (del inglés forward)

g gramo

GFP proteína verde fluorescente (del inglés green fluorescent protein)

GLC cromatografía gas-líquido (del inglés gas-liquid chromatography)

GTP guanosina trifosfato

HDL lipoproteínas de alta densidad (del inglés high density lipoprotein)

HLBPs proteínas que unen ligandos hidrofóbicos (del inglés hydrophobic ligand binding protein)

IgG Inmunoglobulina G

IPTG isopropil $\alpha$-D-tiogalactósido

$\mathrm{K}_{\mathrm{D}} \quad$ constante de disociación

kDa kiloDalton

kg kilogramo

$K_{\mathbf{P}} \quad$ coeficiente de partición

I litro

LB medio Luria Bertani

LDL lipoproteínas de baja densidad (del inglés low density lipoprotein)

LUV vesículas unilamelares grandes (del inglés large unilamellar vesicles)

M molar

mg miligramo

miRNAs microRNAs

$\mathrm{ml} \quad$ mililitro

mM milimolar

mRNA ARN mensajero

NADH nicotinamida adenina dinucleótido reducido

NBD-PC N-(7-nitro-2,1,3-benzoxadiazol-4-yl)-fosfatidilcolina

nm nanómetro

ON durante la noche (del inglés overnight)

PAF paraformaldehído

PAGE electroforesis en gel de poliacrilamida (del inglés polyacrylamide gel electrophoresis)

PAIR punción, aspiración, inyección y reaspiración

pb pares de bases

PCR reacción en cadena de la polimerasa

PEP fosfoenolpiruvato

PEPCK fosfoenolpiruvato carboxiquinasa (del inglés phosphoenolpyruvate carboxykinase)

PM peso molecular

PPAR receptores activados por proliferador de peroxisoma (del inglés peroxisome proliferator-activated receptors)

PS fosfatidilserina

PVDF fluoruro de polivinilideno (del inglés polyvinylidene difluoride)

RNAi interferencia por ARN

RNA-seq secuenciación de ARN 


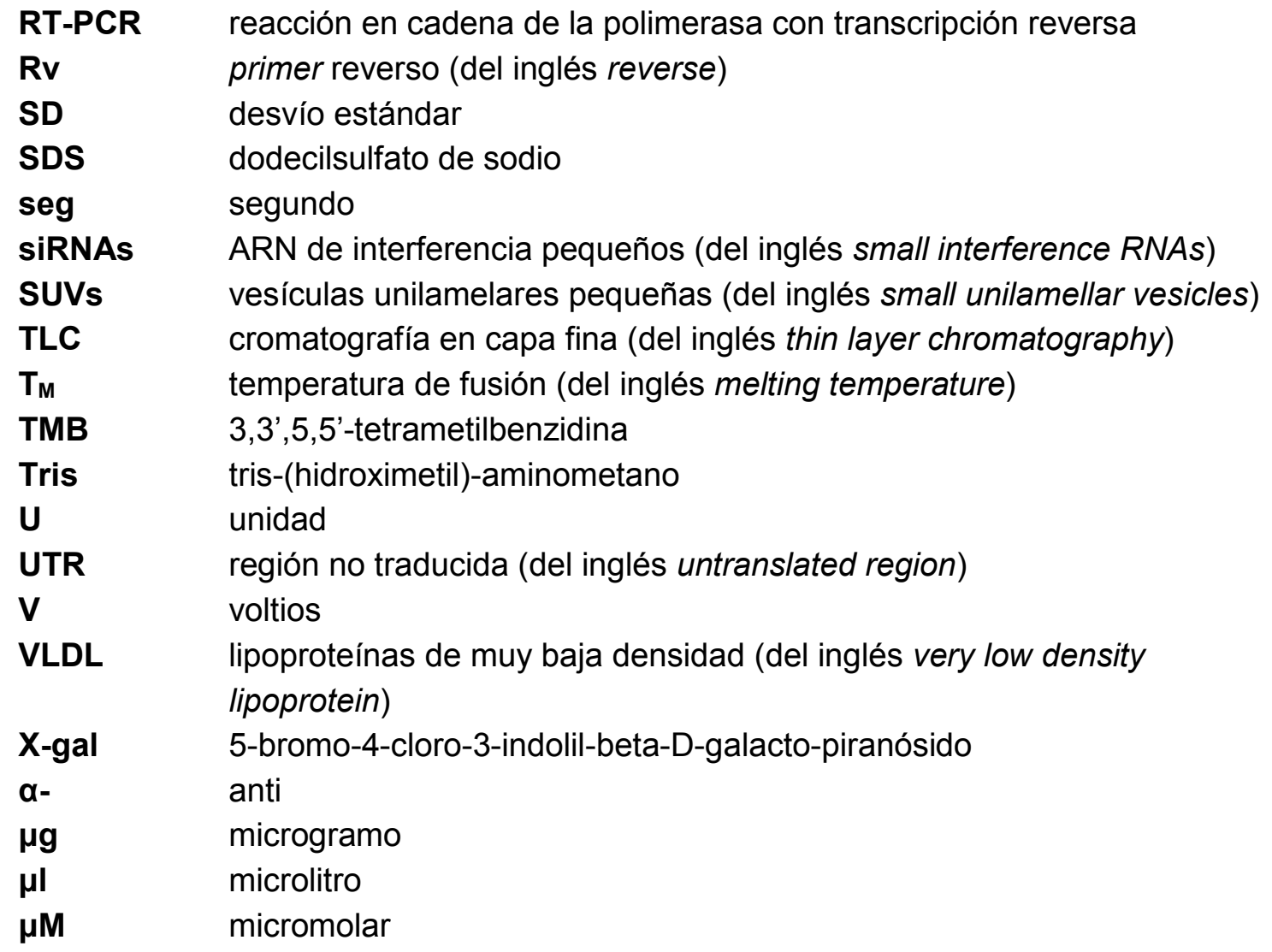

\section{Medios y Buffers}

LB

PBS

TAE

TBE

TBS

TBST

TE

TEK

TFB1

TFB2 10g/l Triptona; $10 \mathrm{~g} / \mathrm{l} \mathrm{NaCl} ; 5 \mathrm{~g} / \mathrm{l}$ Extracto de Levadura

$137 \mathrm{mM} \mathrm{NaCl} ; 10 \mathrm{mM} \mathrm{Na}_{2} \mathrm{HPO}_{4} ; 1,8 \mathrm{mM} \mathrm{KH}_{2} \mathrm{PO}_{4} ; 1 \mathrm{mM} \mathrm{NaN}_{3} ; \mathrm{pH} 7,4$

40mM Tris-Acetato, 1mM EDTA, pH 8

90mM Tris-Borato, 2mM EDTA, $\mathrm{pH} 8$

40mM Tris, $100 \mathrm{mM} \mathrm{NaCl}, \mathrm{pH} 7,4$

$20 \mathrm{mM}$ Tris, $150 \mathrm{mM} \mathrm{NaCl}, 0,1 \%$ Tween $20, \mathrm{pH} 8$

10mM Tris-Hcl, $1 \mathrm{mM}$ EDTA, $\mathrm{pH} 8$

10mM Tris-HCl; $1 \mathrm{mM}$ EDTA; $100 \mathrm{mM} \mathrm{KCl}$; $\mathrm{pH} 7,4$

$100 \mathrm{mM} \mathrm{RbCl} ; 50 \mathrm{mM} \mathrm{MnCl}_{2} ; 30 \mathrm{mM}$ Acetato de Potasio; $10 \mathrm{mM} \mathrm{CaCl}_{2} ; 15 \%$

Glicerol; $\mathrm{pH}$ 5,8

10mM MOPS; $10 \mathrm{mM} \mathrm{RbCl;} 75 \mathrm{mM} \mathrm{CaCl} ; 15 \%$ Glicerol; $\mathrm{pH} 8$ 
Los cestodos del género Echinococcus, en particular su estadio larval o metacestodo, son los agentes patógenos responsables de las enfermedades denominadas hidatidosis 0 echinococcosis, de importancia tanto en la salud humana como de animales domésticos. Las especies más representativas, por su amplia distribución geográfica y el impacto que representan en la economía y la salud pública, son E. granulosus y E. multilocularis. La Organización Mundial de la Salud ha incluido a estas enfermedades dentro de un grupo prioritario de enfermedades tropicales desatendidas.

Estos cestodos, al igual que muchos otros platelmintos parásitos, son incapaces de sintetizar la gran mayoría de sus lípidos de novo, por lo que deben adquirirlos a partir de sus hospedadores. En ese contexto, se cree que las proteínas que unen ácidos grasos (FABPs) podrían tener un rol importante en la adquisición de dichos nutrientes y la distribución de los mismos entre los diferentes tejidos, estadios y/o vías metabólicas de estos cestodos.

Hasta el momento, sólo una FABP de E. granulosus, denominada EgFABP1, ha sido parcialmente caracterizada. Sin embargo, para poder determinar si esta proteína participa en el transporte e intercambio de lípidos, es necesario avanzar en el análisis de los ligandos que EgFABP1 es capaz de unir y en su capacidad de intercambiar estos ligandos. Para ello, en la presente tesis se aplicaron diversas técnicas biofísicas y bioquímicas para la caracterización de la interacción de EgFABP1 con ligandos y membranas fosfolipídicas. Mediante análisis por cromatografía en capa fina y cromatografía gas-líquido de los lípidos que copurifican con EgFABP1 recombinante expresada en Escherichia coli, se logró determinar que en un ambiente celular complejo, como es el citoplasma de una bacteria, EgFABP1 sólo uniría ácidos grasos libres y no lípidos más complejos, como por ejemplo, fosfolípidos. Asimismo, mediante técnicas de proteólisis parcial y dicroísmo circular se estableció que la unión de EgFABP1 a ligandos es capaz de inducir diferentes cambios conformacionales en la proteína, dependiendo del tipo de ácido graso al que se una. Por otro lado, el estudio de los mecanismos de transferencia de ácidos grasos fluorescentes a membranas fosfolipídicas artificiales mostró que EgFABP1 emplearía un mecanismo de transferencia de tipo colisional, lo cual implica que la proteína debe interactuar con la membrana para entregar sus ligandos. Esto es similar a lo observado para FABPs de mamíferos, ampliamente estudiadas, que se asemejan a EgFABP1 tanto a nivel de secuencia como de estructura terciaria, lo que puede facilitar el enfoque de futuros estudios sobre esta proteína de E. granulosus.

Por otra parte, la exploración de los genomas de E. granulosus y E. multilocularis recientemente publicados, permitió establecer la existencia de un total de seis genes de FABPs en cada una de las dos especies, destacándose en el caso de $E$. multilocularis el hecho de que dos de esos genes codifican para una misma proteína. En el presente trabajo, se clonaron las cinco secuencias codificantes de E. multilocularis, por lo que se pudo establecer experimentalmente parte de la estructura génica de dichos genes. Asimismo, 
ensayos preliminares sugieren que estas FABPs se expresan diferencialmente en distintos tejidos del parásito. Por otro lado, se realizó una caracterización bioinformática de los genes y proteínas FABPs predichos en ambos cestodos, comparándolos con información existente sobre proteínas de esta familia en otros organismos.

En conjunto, los resultados obtenidos en esta tesis amplían el conocimiento relativo a las FABPs de Echinococcus spp., revelando la existencia de toda una familia de FABPs que podrían cumplir roles específicos en diferentes tejidos y/o estadios de estos parásitos. A diferencia de lo que se creía previamente, esto plantea un panorama bastante más complejo en el transporte y metabolismo de ácidos grasos, y posiblemente otros ligandos hidrofóbicos, en parásitos cestodos. Asimismo, la capacidad de EgFABP1 de interactuar con membranas y transferir ácidos grasos podría implicar su relación con el transporte y derivación de ligandos hacia diferentes compartimentos y/o vías metabólicas en las células de E. granulosus. Los cambios conformacionales inducidos por ciertos ligandos, podrían tener implicancias desde el punto de vista de la señalización y regulación génica, análogamente a lo descripto para otras FABPs. 


\section{INTRODUCCIÓN}

El presente trabajo aborda diferentes aspectos vinculados a las proteínas que unen ácidos grasos (FABPs) de parásitos cestodos del género Echinococcus; en particular, de las especies E. granulosus y E. multilocularis. En esta sección se pretende presentar información básica en relación a los helmintos parásitos, prestando particular atención a las especies antes mencionadas. Asimismo, se brindará información relativa a las FABPs, partiendo de los conocimientos acumulados en relación a las FABPs de mamíferos (las primeras en ser descubiertas y las más estudiadas), pasando por FABPs de invertebrados en general, hasta llegar a las de E. granulosus.

\subsection{Parasitismo}

Es sabido que en la naturaleza conviven e interactúan entre sí organismos de diferentes especies, con diferentes grados de dependencia. Dichas asociaciones se conocen como simbiosis. De acuerdo a la dependencia entre el simbionte y el hospedador, se admiten normalmente tres grados de simbiosis: mutualismo, comensalismo y parasitismo.

En el caso del mutualismo, se benefician tanto el hospedador como los simbiontes, y existe una dependencia fisiológica mutua. Un ejemplo de mutualismo lo constituyen las termitas y sus protozoos intestinales. Las termitas proporcionan el hábitat y la celulosa, proveniente de la madera, que ellas no son capaces de digerir. Los protozoos intestinales, por su parte, son capaces de hidrolizar la celulosa, la cual puede ser usada tanto para su propio beneficio como también para el de las termitas.

Por su parte, el comensalismo consiste en un fenómeno en el que el hospedador brinda el hábitat y el alimento a sus simbiontes, sin resultar él dañado ni beneficiado. Al hospedador le resulta indistinto interactuar o no con sus simbiontes. Los simbiontes, sin embargo, sí dependen fisiológicamente de su hospedador. Ejemplos de comensales resultan ser ciertos protozoos que viven en el intestino del hombre.

El parasitismo es la relación en la cual el simbionte, que es fisiológicamente dependiente de su hospedador, puede perjudicar a este último. Los trematodos, cestodos, acantocéfalos, y varios protozoos y nematodos resultan ser ejemplos de parásitos animales (Olsen, 1977a).

\subsubsection{Clases de parásitos}

Existen diferentes clasificaciones de parásitos dependiendo de la localización en el cuerpo y el período que pasa el parásito en contacto con su hospedador, así como del grado de 
dependencia con el mismo. Si los parásitos viven sobre la superficie externa del hospedador son considerados ectoparásitos, mientras que si el hábitat es el interior del hospedador, los mismos son denominados endoparásitos. Los ectoparásitos pueden vivir sobre la superficie propiamente dicha del cuerpo del hospedador, o bien sobre cavidades que comunican directamente con el exterior, como pueden ser las branquias de los peces. Los ejemplos más comunes de este tipo de parásitos resultan ser los piojos y garrapatas. Por su parte, los endoparásitos pueden hallarse en diferentes localizaciones del interior del organismo del hospedador como pueden ser el tubo digestivo, los pulmones, el hígado y muchos otros tejidos y células. Ejemplos de este tipo de parásitos son los cestodos, trematodos digeneos, nematodos y protozoos.

Teniendo en cuenta el período que los parásitos pasan sobre o dentro del hospedador, se los puede clasificar como parásitos temporales o parásitos estacionarios. Los parásitos temporales solo tienen contacto con el hospedador para alimentarse. Una vez satisfechas sus necesidades, lo abandonan. Ejemplos claros de este tipo de organismo resultan ser los artrópodos hematófagos y las sanguijuelas. Los parásitos estacionarios, por su parte, pasan un período definido de su ciclo de vida dentro o sobre su hospedador. Dependiendo de la duración de dicho período, se los puede subdividir a su vez en: parásitos periódicos, que son aquellos que pasan parte de su ciclo de desarrollo en contacto con el hospedador y luego lo abandonan para adoptar un tipo de vida no parasitario, y parásitos permanentes, que son los que permanecen durante toda su existencia en los hospedadores, salvo por los momentos en los que pasan de un hospedador a otro.

Por otra parte, se habla de parásitos accidentales cuando los mismos aparecen en hospedadores poco comunes, y parásitos erráticos cuando migran a órganos poco comunes de un hospedador normal.

Todas las clasificaciones mencionadas se aplican a parásitos obligados, es decir, organismos cuyo desarrollo se lleva a cabo, al menos en parte, en su hospedador. Sin embargo, existen animales que a pesar de ser, en condiciones normales, organismos de vida libre, pueden existir durante breves períodos en el cuerpo de otros animales a los que llegan accidentalmente. Este tipo de organismos son considerados parásitos facultativos e incluyen ciertos nematodos de vida libre, así como larvas de algunas moscas (Olsen, 1977a).

\subsubsection{Características del parasitismo}

La característica más destacable del parasitismo es la capacidad de adaptación. Si bien las necesidades básicas de un parásito son similares a las de los organismos de vida libre (hábitat, alimento, reproducción), su modo de vida dependiente de otro organismo ha llevado 
a que los parásitos desarrollen diversas adaptaciones para poder ingresar, permanecer y, eventualmente, salir de su hospedador.

Para poder vivir en un determinado hospedador, los parásitos han debido desarrollar estructuras para poder aferrarse a él. Esas adaptaciones consisten en ganchos, ventosas y otras estructuras de adherencia.

Asimismo, ciertos parásitos necesitan poder salir de su hospedador para poder infectar uno nuevo. Para ello, se utilizan diferentes vías dependiendo de cuál sea la localización del parásito en el cuerpo del hospedador. Los que se localizan en el aparato digestivo, pulmones, hígado o sistema reproductor, pueden utilizar las salidas naturales de dichos sistemas como vías para eliminar quistes o huevos. Los que viven en sistema circulatorio, como el protozoo causante de la malaria, generalmente requieren de animales hematófagos que les permitan salir de su hospedador. En muchos casos, se completa parte del desarrollo en el organismo que sirve como vector de dichos parásitos, el cual también servirá para inocular al parásito en nuevos hospedadores. Ciertos gusanos que se alojan en tejidos subcutáneos son capaces de dañar la epidermis y formar aberturas a través de las cuales sus larvas pueden salir para infectar nuevos hospedadores. Otros organismos, como los cestodos, abandonan a su hospedador intermediario por medio de predadores o carroñeros, los cuales son, a su vez, sus hospedadores definitivos.

Por otra parte, los parásitos han desarrollado también adaptaciones importantes para poder sobrevivir en los períodos de transferencia entre un hospedador y otro. Aquellos que tienen un ciclo vital directo, en el cuál existe un período de desarrollo en el suelo o el agua, se observa el desarrollo de quistes protectores, huevos con gruesas membranas, larvas con cutículas protectoras y otras adaptaciones tendientes a brindar protección frente a los riesgos de desecación, congelación y demás inclemencias climáticas. Los parásitos con ciclo vital indirecto, es decir, que tienen períodos de desarrollo en al menos un hospedador intermediario, pueden poseer alguna de las características antes mencionadas para períodos de transferencia entre distintos hospedadores. Sin embargo, dado que la mayor parte del tiempo su desarrollo se lleva a cabo dentro de algún hospedador, estos organismos deben adaptarse a los diferentes medios bióticos que constituyen los cuerpos de sus diferentes hospedadores. La supervivencia en los diferentes hospedadores depende de la capacidad que hayan desarrollado los parásitos para resistir las reacciones inmunológicas del hospedador, la acción de los jugos digestivos, o bien la habilidad para alcanzar hábitats donde existan los nutrientes necesarios para el crecimiento y reproducción en niveles adecuados. Cabe destacar que los parásitos más eficaces resultan ser los que han desarrollado una mayor capacidad reproductiva, con la finalidad de compensar las posibles pérdidas causadas a lo largo de sus complejos ciclos de vida. Dicho potencial puede alcanzarse mediante el aumento de la producción de huevos, la duplicación de órganos sexuales en segmentos (como ocurre 
en los cestodos), o mediante reproducción asexual extendida por largos períodos (Olsen, 1977a).

\subsection{Cestodos}

El phylum Platyhelminthes, incluye una gran variedad de especies de gusanos, tanto parásitos como de vida libre. Los miembros de las clases Trematoda, Monogenea y Cestoda constituyen la mayor parte de los platelmintos parásitos. Los platelmintos son gusanos, o helmintos, planos (dorsoventralmente aplanados). Se caracterizan por tener cuerpos bilateralmente simétricos, carentes de cutículas o capas protectivas, por tener un bajo grado de cefalización, y carecer de ano. Usualmente son hermafroditas (Brusca \& Brusca, 2003; Maule \& Marks, 2006).

Dentro del phylum Platyhelminthes, son de particular interés para el presente trabajo los organismos pertenecientes a la clase Cestoda. Los cestodos son, en su forma adulta, gusanos planos con forma de cinta, exclusivamente endoparásitos (Brusca \& Brusca, 2003; Olsen, 1977b; Smyth \& McManus, 2007). Los estadios adultos de los parásitos pertenecientes a la subclase Eucestoda se localizan casi exclusivamente en el tubo digestivo de hospedadores vertebrados. Algunas excepciones se localizan en órganos y tejidos relacionados de igual manera con procesos digestivos como pueden ser la vesícula biliar o los túbulos pancreáticos (Brusca \& Brusca, 2003; Smyth \& McManus, 2007).

Dado que los parásitos del género Echinococcus (sobre los cuales se centra el presente trabajo) pertenecen a la familia Taeniidae, dentro del Orden Cyclophillidea de los Eucestoda (Brusca \& Brusca, 2003; Olsen, 1977b); se describirá brevemente a continuación la anatomía de los cestodos tenioides. Dichos organismos, en su estadio adulto, presentan tres zonas bien definidas y características: el escólex, el cuello y el estróbilo.

El escólex es un órgano de fijación que en el caso de los cestodos del orden Cyclophillidea es de tipo acetabulado, con presencia de ventosas. Este tipo de escólex puede ser a su vez penetrativo o no penetrativo. Estos últimos, como su nombre lo indica, no penetran demasiado profundamente en la mucosa intestinal del hospedador, mientras que los escólex penetrativos permiten una fijación al hospedador más íntima, dado que invaden las criptas de Lieberkühn del intestino del hospedador. En los Taeniidae, este tipo de escólex usualmente posee, aparte de las ventosas, un rostelo, que es una extensión en forma de cúpula o dedo sobre el mismo. En muchas especies el rostelo posee ganchos que colaboran con la fijación del parásito a la mucosa de su hospedador. En varias especies se han descripto glándulas de secreción en el escólex, aunque sus funciones no han sido claramente definidas (Smyth \& McManus, 2007). 
El cuello es una pequeña región, inmediatamente posterior al escólex, que contiene una zona germinativa desde donde se originan las proglótides que forman el estróbilo (Brusca \& Brusca, 2003).

El estróbilo consiste en un tronco elongado, segmentado, formado por proglótides (Brusca \& Brusca, 2003). Cabe destacar que, aunque se observan constricciones en el estróbilo que delimitan las proglótides, el interior posee un parénquima ininterrumpido y existen músculos longitudinales que atraviesan la totalidad del cuerpo del organismo (Smyth \& McManus, 2007). El grado de maduración de las proglótides aumenta conforme las mismas se alejan del escólex. A medida que se van formando nuevas proglótides a partir del cuello, las más viejas se alejan del escólex, maduran, resultan inseminadas y se llenan de embriones (Brusca \& Brusca, 2003).

Dada la ausencia de aparato digestivo en los cestodos, la pared de su cuerpo ha debido adaptarse para llevar a cabo tareas de absorción de nutrientes y eliminación de desechos. Dicha pared, el tegumento, es un epitelio sincitial (Ver Figura l-1). El mismo está constituido por dos zonas: una superficial, anucleada, denominada citoplasma distal; y una nucleada, denominada citoplasma proximal, que se encuentra en el mesénquima. El citoplasma distal contiene abundantes mitocondrias, gránulos y vesículas. Dichos gránulos y vesículas derivarían del aparato de Golgi ubicado en el citoplasma proximal, y estarían involucrados en el mantenimiento del glicocálix. El citoplasma proximal y el distal se encuentran conectados mediante túbulos citoplasmáticos que atraviesan la lámina basal (Smyth \& McManus, 2007). Una característica del tegumento de los cestodos es que en su superficie externa cuenta con plegamientos llamados microtricos, que suelen compararse con las microvellosidades intestinales. Se ha propuesto que los microtricos no sólo aumentarían la superficie de absorción del tegumento, sino que también servirían como estructuras adhesivas (para evitar que el parásito sea expulsado del tubo digestivo). Asimismo, sus extremos puntiagudos servirían para erosionar las células del hospedador, permitiendo una mayor disponibilidad de nutrientes para el parásito (Olsen, 1977b). Como se mencionó más arriba, por fuera de la membrana apical del tegumento existe una capa de glicocálix, el cual está formado por mucopolisacáridos y glicoproteínas. En cestodos, la alta proporción de grupos acídicos que forman el glicocálix otorga una carga neta negativa a dicha superficie. Entre otras propiedades, el glicocálix tiene la capacidad de concentrar iones, tanto orgánicos como inorgánicos, que podrían servir para activar enzimas unidas a la membrana plasmática de los cestodos. Asimismo, tendría capacidad de unir sustancias con alto peso molecular, como enzimas del hospedador (Smyth \& McManus, 2007). 


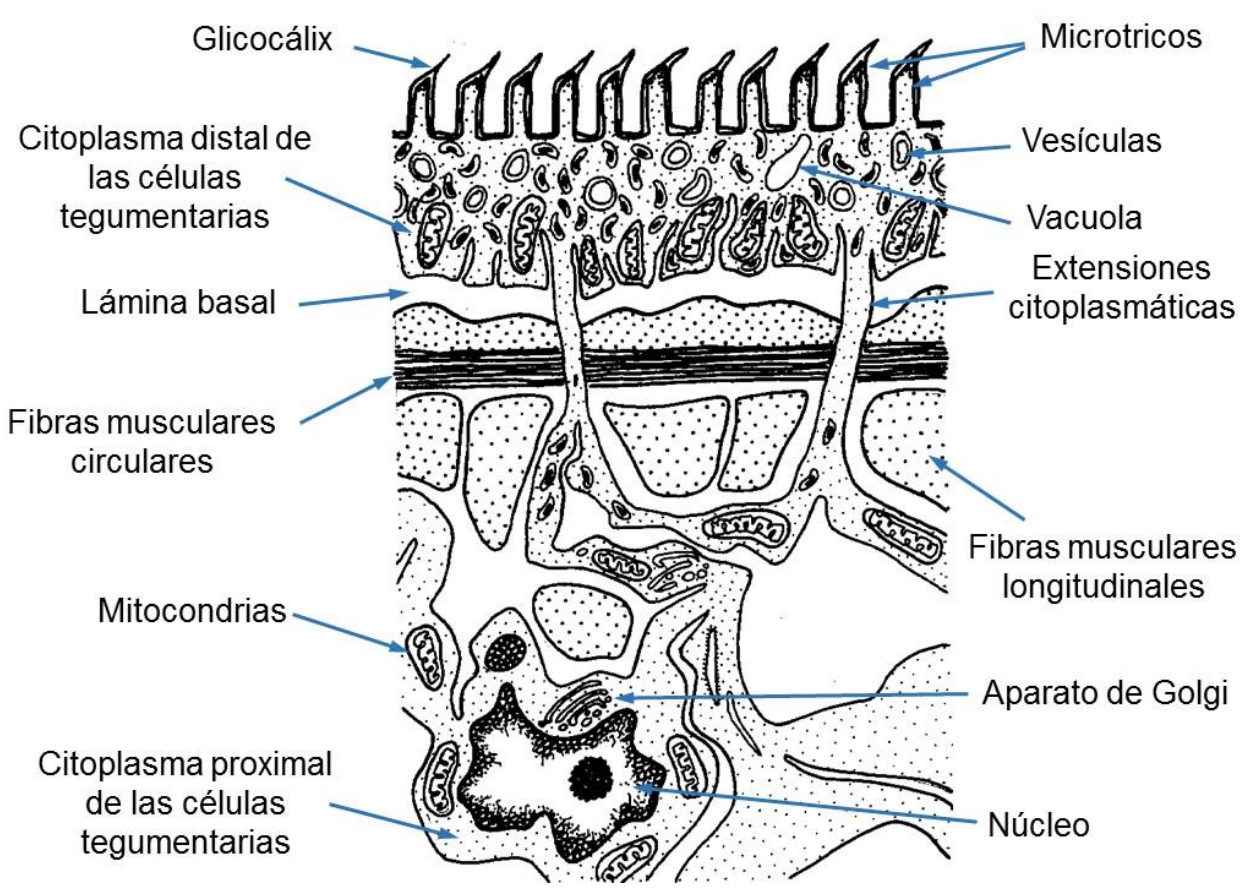

Figura I-1. Esquema del tegumento de un cestodo adulto. El tegumento se compone de una zona más superficial, anucleada, que se conecta por extensiones citoplasmáticas al cuerpo de la célula tegumentaria, en donde se localiza el núcleo y otras organelas. En la superficie del tegumento hay estructuras llamadas microtricos, las cuales a su vez se recubren de glicocálix. En el citoplasma distal existen también numerosos gránulos y vesículas, posiblemente de secreción. La figura ha sido adaptada del Banco de Recursos Educativos Multimedia de la Universidad de Ottawa, BIODIDAC (http://biodidac.bio.uottawa.ca/).

\subsection{Género Echinococcus}

Los cestodos del género Echinococcus, en particular su estadio larval (o metacestodo), son los agentes responsables de las enfermedades conocidas como hidatidosis o echinococcosis. La hidatidosis quística y la hidatidosis alveolar son las dos formas más frecuentes en humanos, y son provocadas por E. granulosus y E. multilocularis, respectivamente.

Estas zoonosis forman parte de un grupo de 17 enfermedades tropicales desatendidas, prioritarias para la Organización Mundial de la Salud. En su conjunto, esas 17 enfermedades afectan a más de 1000 millones de personas alrededor del mundo, generando mayores impactos en los países con economías más vulnerables (WHO, 2015). 


\subsubsection{Ciclo de vida de Echinococcus spp.}

El ciclo de vida de Echinococcus spp. (Ver Figura l-2) se caracteriza por ser un ciclo indirecto, en el que están involucrados dos hospedadores mamíferos. De modo muy general, se puede decir que el ciclo involucra a animales carnívoros como hospedadores definitivos (alojan el estadio adulto), y sus respectivas presas como hospedadores intermediarios (alojan al estadio larval) (Ver Tabla l-1).
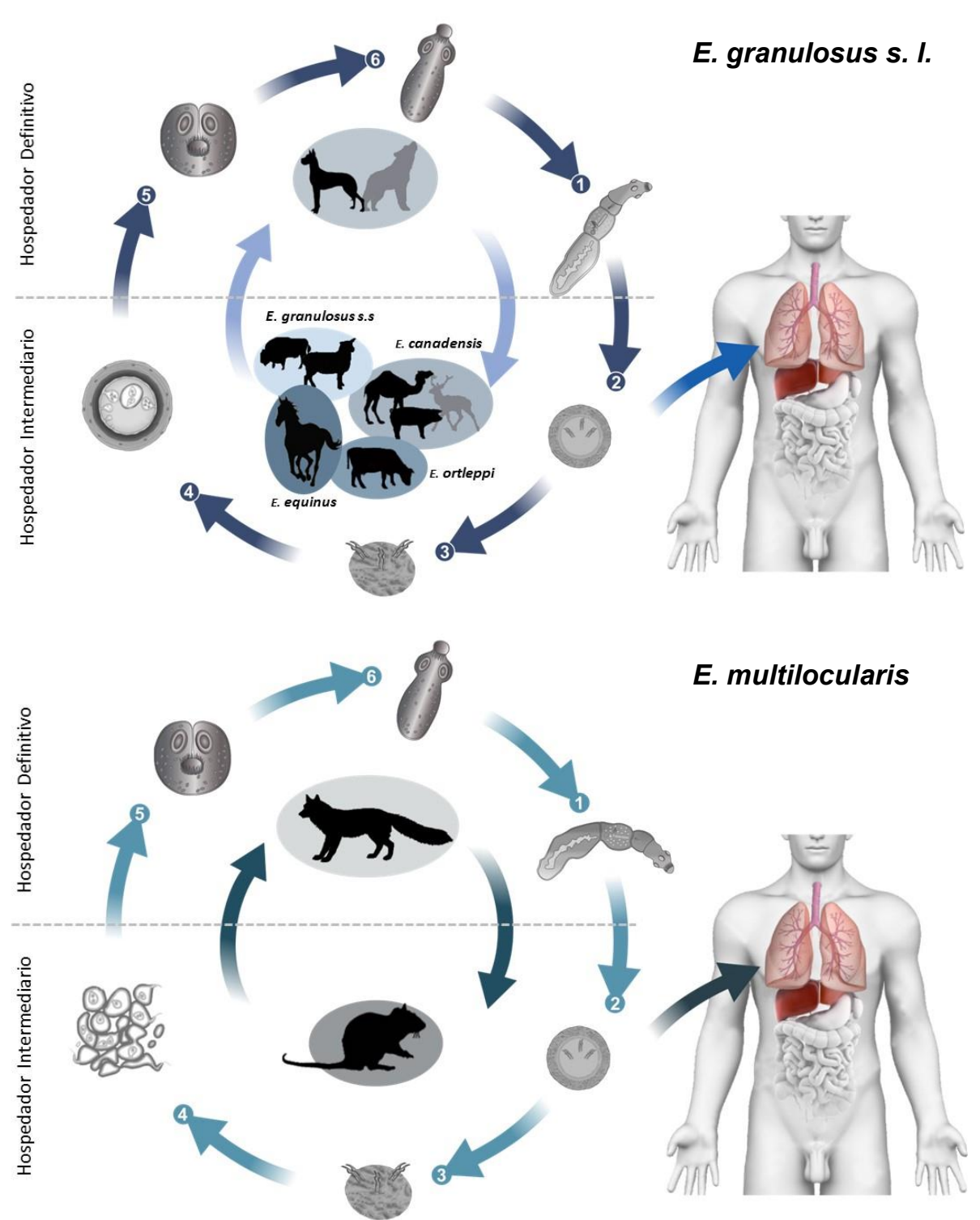

Figura I-2. Esquema de los ciclos de vida de E. granulosus s.I. y E. multilocularis. En la figura se pueden ver esquematizados los diferentes estadios de los parásitos, así como los hospedadores en los que ingresan o se desarrollan cada uno de ellos. Los estadios son: (1) Adulto, (2) Huevo, (3) Oncosfera, (4) Metacestodo, (5) Protoescólex invaginado, (6) Protoescólex evaginado. En el ciclo de E. granulosus s. I. se esquematizan diversos hospedadores intermediarios. Son aquellos que dieron nombre a las diversas cepas, que luego pasaron a considerarse especies y son las que se indican en el gráfico. Los humanos actúan en ambos casos como hospedadores accidentales. 
Dado que el parásito adulto se aloja en el intestino de su hospedador definitivo, los huevos infectivos son eliminados con las heces del hospedador y son capaces de contaminar el agua y las pasturas que frecuentan los animales que actúan como hospedadores intermediarios.

Cuando los huevos de Echinococcus spp. son ingeridos por los hospedadores intermediarios, los mismos eclosionan al alcanzar el intestino delgado del hospedador y liberan la oncosfera (o hexacanto).

La oncosfera atraviesa la pared del intestino y alcanza las vénulas de la porta hepática. A través del torrente sanguíneo, la oncosfera alcanza el hígado, los pulmones u otros órganos del hospedador intermediario en donde es capaz de establecerse y dar origen a un metacestodo (estadio larval), cuyas características pueden variar dependiendo de cuál sea la especie del género Echinococcus involucrada (Ver más adelante), aunque en todas ellas se trata de estructuras quísticas dentro de las cuáles se generan, por reproducción asexual, gran cantidad de protoescólices.

El ciclo de vida del parásito se cierra cuando el hospedador definitivo ingiere metacestodos alojados en las vísceras de su presa. Al pasar por el sistema digestivo del hospedador definitivo, se liberan los protoescólices que desarrollarán gusanos adultos en el intestino de dicho animal. Cabe destacar que los humanos pueden actuar como un hospedador accidental, siendo capaces de alojar metacestodos de Echinococcus spp. en sus órganos internos.

\subsubsection{Especies pertenecientes al género Echinococcus}

El número de especies pertenecientes al género Echinococcus ha sido tema de debate entre los especialistas durante muchos años. Tal es así, que no fue sino hasta la década del 50 del siglo XX que se determinó que la especie responsable de la echinococcosis alveolar era E. multilocularis, y no E. granulosus como se creía hasta ese momento (Nakao et al., 2013). Por otra parte, las variaciones fenotípicas observadas en aislamientos de Echinococcus obtenidos a partir de diferentes hospedadores intermediarios generaban aún más confusión al momento de determinar las especies pertenecientes a dicho género. Se observaban diferencias en el desarrollo de parásitos provenientes de diferentes especies de hospedadores intermediarios, diferencias en la infectividad de los mismos, ya sea hacia humanos o hacia otros potenciales hospedadores, etc. Dichas variaciones, hicieron necesario adoptar un sistema informal de designación de esas variantes o "cepas" de E. granulosus (Thompson \& McManus, 2002). Las cepas se definieron como variantes "que difieran estadísticamente de otros grupos de la misma especie en frecuencias de genes, y en uno o más caracteres que sean o pudieran ser relevantes para la epidemiología o control de la echinococcosis" (Thompson \& Lymbery, 1988). De esta manera, se definieron las cepas oveja, búfalo, caballo, vaca, camello, cerdo, cérvido y león, basándose principalmente en la 
especificidad por el hospedador intermediario; salvo por la cepa león, que se definió en base a la especificidad por el hospedador definitivo. Mientras tanto, se incluían solamente cuatro especies dentro del género Echinococcus: E. granulosus, E. multilocularis, E. vogeli y E. oligarthra (previamente designado E. oligarthrus) (Nakao et al., 2013). Posteriormente, con el avance en las técnicas de secuenciado de $A D N$, se comenzaron a analizar genes mitocondriales y nucleares de los diversos integrantes del género Echinococcus. Dichos estudios confirmaron que E. multilocularis, E. vogeli y E. oligarthra eran diferentes entre sí y que E. granulosus podía subdividirse en diferentes genotipos (indicados con la letra G seguida de un número), los cuales se correspondían a su vez con las cepas previamente determinadas en base a observaciones fenotípicas. La relación entre los genotipos y las cepas resultó ser la siguiente: G1 (cepa oveja), G2 (cepa oveja de Tasmania), G3 (cepa búfalo), G4 (cepa caballo), G5 (cepa vaca), G6 (cepa camello), G7 (cepa cerdo), G8 (cepa cérvido) y G10 (cepa cérvidos de Escandinavia). El genotipo G9 es aún motivo de discusión y se considera, hasta que se demuestre lo contrario, una variación del genotipo G7 (Alvarez Rojas et al., 2014; Nakao et al., 2013). Posteriormente, y a medida que progresaban los estudios filogenéticos basados en secuencias de ADN, incluyendo secuencias completas de ADN mitocondrial, se observó que los genotipos de E. granulosus eran aún más divergentes de lo que se creía. Tal es así, que se reconsideró la taxonomía del género Echinococcus, de modo tal que, hoy por hoy, se considera a $E$. granulosus como un complejo de especies que incluye a $E$. granulosus sensu stricto (genotipos G1 a G3), E. equinus (G4), E. ortleppi (G5) y, en principio, E. canadensis que incluiría a los genotipos G6-G10 (Nakao et al., 2013; H. Zheng et al., 2013). En su conjunto, estas especies pueden denominarse E. granulosus sensu lato (E. granulosus s. I.). Asimismo, lo que se consideraba "cepa león" de E. granulosus, pasó luego a ser considerada una nueva especie, E. felidis; y se descubrió también otra especie en China, más relacionada a E. multilocularis, denominada E. shiquicus (McManus, 2013; Nakao et al., 2013). Recientemente, se ha sugerido que sería posible una división de E. canadensis (G6 a G10) en otras tres especies (Lymbery et al., 2015). Si bien dichos autores sostienen que aún resta trabajo por hacer en cuanto al análisis genético de dichas variantes, se apoyan en el hecho de que existen diferencias en la distribución geográfica, rango de hospedadores y morfología de las mismas, suficientes como para proponer que se designen nuevas especies a partir de los genotipos mencionados dentro de E. canadensis. Lo que se propone es retomar nomenclaturas propuestas en los estudios morfológicos que describieron originalmente la diferencia entre dichos organismos. De este modo, lo que se postula es que $E$. canadensis (G6/G7) pase a ser E. intermedius, E. canadensis (G8) sea E. borealis, y E. canadensis (G10) permanezca como tal (Lymbery et al., 2015). Claramente, este es un campo de estudio muy amplio en el que todavía pueden surgir novedades. Para los fines de este trabajo, al hablar de E. granulosus se hará referencia a $E$. granulosus s. I., salvo que se especifique lo contrario. 
En la Tabla l-1 se muestra una compilación de la información discutida en los párrafos previos a modo de resumen del estado actual en materia de taxonomía del género Echinococcus (McManus, 2013; Moro \& Schantz, 2009; Nakao et al., 2013; Thompson \& McManus, 2002).

\begin{tabular}{|c|c|c|c|c|c|c|}
\hline Especie & Genotipos & Cepas & Distribución & $\begin{array}{l}\text { Hospedador } \\
\text { Definitivo }^{\text {(a) }}\end{array}$ & $\begin{array}{l}\text { Hospedador } \\
\text { Intermediario }^{(a)}\end{array}$ & $\begin{array}{l}\text { Tipo de } \\
\text { metacestodo }\end{array}$ \\
\hline $\begin{array}{l}\text { E. granulosus } \\
\text { sensu stricto }\end{array}$ & $\mathrm{G} 1 / \mathrm{G} 2 / \mathrm{G} 3$ & $\begin{array}{l}\text { Oveja/Oveja de } \\
\text { Tasmania/Búfalo }\end{array}$ & Mundial & $\begin{array}{l}\text { Perro, zorro, dingo, } \\
\text { chacal, hiena }\end{array}$ & $\begin{array}{l}\text { Oveja, vaca, } \\
\text { cabra, cerdo, } \\
\text { camello, canguro }\end{array}$ & Unilocular \\
\hline E. equinus & G4 & Caballo & $\begin{array}{l}\text { Mundial } \\
\text { (Esporádico) }\end{array}$ & Perro & $\begin{array}{l}\text { Caballo, otros } \\
\text { equinos }\end{array}$ & Unilocular \\
\hline E. ortleppi & G5 & Vaca & Mundial & Perro & $\begin{array}{l}\text { Vaca, oveja, } \\
\text { búfalo, cabra }\end{array}$ & Unilocular \\
\hline $\begin{array}{l}\text { E. canadensis } \\
\text { (E. intermedius) }^{\text {(b) }}\end{array}$ & G6/G7 & Camello/Cerdo & Mundial & Perro & $\begin{array}{l}\text { Camello, cerdo, } \\
\text { vaca, oveja, } \\
\text { cabra }\end{array}$ & Unilocular \\
\hline 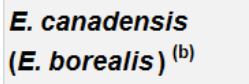 & G8 & Cérvidos & $\begin{array}{l}\text { Ártica norte y } \\
\text { boreal }\end{array}$ & Lobo & $\begin{array}{l}\text { Alce, ciervo } \\
\text { canadiense }\end{array}$ & Unilocular \\
\hline $\begin{array}{l}\text { E. canadensis } \\
\text { (E. canadensis) }^{\text {(b) }}\end{array}$ & G10 & $\begin{array}{l}\text { Cérvidos de } \\
\text { Escandinavia }\end{array}$ & $\begin{array}{l}\text { Ártica norte y } \\
\text { boreal }\end{array}$ & Lobo, perro & $\begin{array}{l}\text { Alce, reno, ciervo } \\
\text { canadiense }\end{array}$ & Unilocular \\
\hline E. multilocularis & $\begin{array}{l}\text { Europeo, } \\
\text { Asiático, } \\
\text { Norteamericano }\end{array}$ & & Holártica & $\begin{array}{l}\text { Zorro rojo, zorro } \\
\text { ártico, lobo, coyote, } \\
\text { perro, gato }\end{array}$ & $\begin{array}{l}\text { Roedores } \\
\text { arvicolinos, mono }\end{array}$ & Alveolar \\
\hline E. vogeli & & & Neotropical & $\begin{array}{l}\text { Perro venadero ( } S . \\
\text { venaticus), perro }\end{array}$ & $\begin{array}{l}\text { Paca, agutí } \\
\text { (Dasyprocta } \\
\text { spp.) }\end{array}$ & Poliquístico \\
\hline E. oligarthra & & & Neotropical & $\begin{array}{l}\text { Felinos salvajes } \\
\text { (puma, jaguar, } \\
\text { yaguarundí, ocelote) }\end{array}$ & Paca, agutí & Poliquístico \\
\hline E. shiquicus & & & $\begin{array}{l}\text { Meseta } \\
\text { tibetana }\end{array}$ & Zorro tibetano & Pica & Unilocular \\
\hline E. felidis & & León & África & León, ¿hiena? & $\begin{array}{l}\text { ¿Facóquero } \\
\text { común? }\end{array}$ & ¿Unilocular? \\
\hline
\end{tabular}

Tabla I-1. Taxonomía del género Echinococcus. La tabla muestra un resumen del estado actual de la taxonomía del género Echinococcus, incluyendo algunos datos generales de distribución geográfica de las distintas especies, posibles hospedadores y tipo de metacestodo que generan en sus hospedadores intermediarios. Con fondo gris se destacan las especies que conforman el complejo conocido como $E$. granulosus sensu lato.

(a) Se enumeran sólo algunos hospedadores susceptibles.

(b) El reconocimiento de las especies entre paréntesis ha sido recientemente propuesto por Lymbery et al. (2015)

\subsubsection{Morfología de Echinococcus spp.}

A continuación se presentarán brevemente las características morfológicas de los diferentes estadios de los cestodos pertenecientes al género Echinococcus. De no especificarse, se estará considerando a E. granulosus s. I. 


\subsubsection{Adulto}

El adulto es el estadio de Echinococcus spp. que se aloja en el intestino de su hospedador definitivo. Se puede decir de modo general que el estadio adulto de Echinococcus spp. es un gusano muy pequeño, de entre $2 \mathrm{~mm}$ a $1 \mathrm{~cm}$ de longitud (dependiendo de la especie) que consiste en un escólex, un cuello y entre 3 y 5 proglótides, de las cuales las primeras son inmaduras, las intermedias son sexualmente maduras, y las últimas, grávidas (contienen huevos ya desarrollados) (Nakao et al., 2013).

El escólex de Echinococcus spp. se caracteriza por ser acetabulado (con cuatro ventosas), y por poseer un rostelo armado con dos filas de ganchos, unos mayores y otros menores. El tamaño de los ganchos varía de una especie a otra y se ha utilizado, junto a otros caracteres, para diferenciarlas.

A continuación del escólex se extiende un pequeño segmento alargado, el cuello, que da origen a las proglótides, las cuales constituyen las unidades reproductoras del estadio adulto, hermafrodita, de Echinococcus spp. (Ver Figura I-3).

El sistema reproductor masculino consiste en un gran número de testículos distribuidos por el parénquima, los cuales se conectan, a través de los vasos deferentes, a la vesícula seminal que se encuentra en la bolsa del cirro. El sistema reproductor femenino, por su parte, consiste en un ovario desde donde surge el oviducto, el cual desemboca a su vez en el ootipo, que es una especie de cámara donde se ensamblan varios componentes de los huevos. El ootipo se encuentra a su vez rodeado por la glándula de Mehlis, mientras que el útero se extiende a lo largo de la proglótide y se conecta con el ootipo. El receptáculo seminal, donde ocurre la fertilización, se conecta con la vagina, la cual desemboca junto a la bolsa del cirro en un atrio genital común (Brownlee et al., 1994). La ubicación del atrio genital en las proglótides, así como variaciones morfológicas de los órganos reproductores varían ligeramente entre las distintas especies del género Echinococcus (Lymbery et al., 2015).

Se ha reportado que varias especies del género Echinococcus son capaces de autoinseminarse. Esto es, el cirro (órgano sexual masculino) se introduce en la vagina de la misma proglótide para llevar a cabo la inseminación (Smyth \& McManus, 2007). Aunque la inseminación cruzada (entre proglótides de diferentes individuos) sería teóricamente posible, no ha podido demostrarse que verdaderamente ocurra. Por otra parte, la auto-inseminación entre dos proglótides diferentes de un mismo individuo es considerada poco probable tanto por la corta distancia que las separa, que impediría que el cestodo pueda doblarse para que entren en contacto ambos poros genitales, como por el hecho de que en Echinococcus spp. no suele haber dos proglótides con el mismo grado de madurez al mismo tiempo (Mohammadzadeh et al., 2014; Smyth \& McManus, 2007). Luego de la fertilización, una vez que los huevos se desarrollan por completo, el útero queda extendido, ocupando 
prácticamente la totalidad del último segmento, esto es, la proglótide grávida. Es justamente ese segmento el que al desprenderse del estróbilo posibilita la dispersión de los huevos en el ambiente a través de las heces del hospedador.

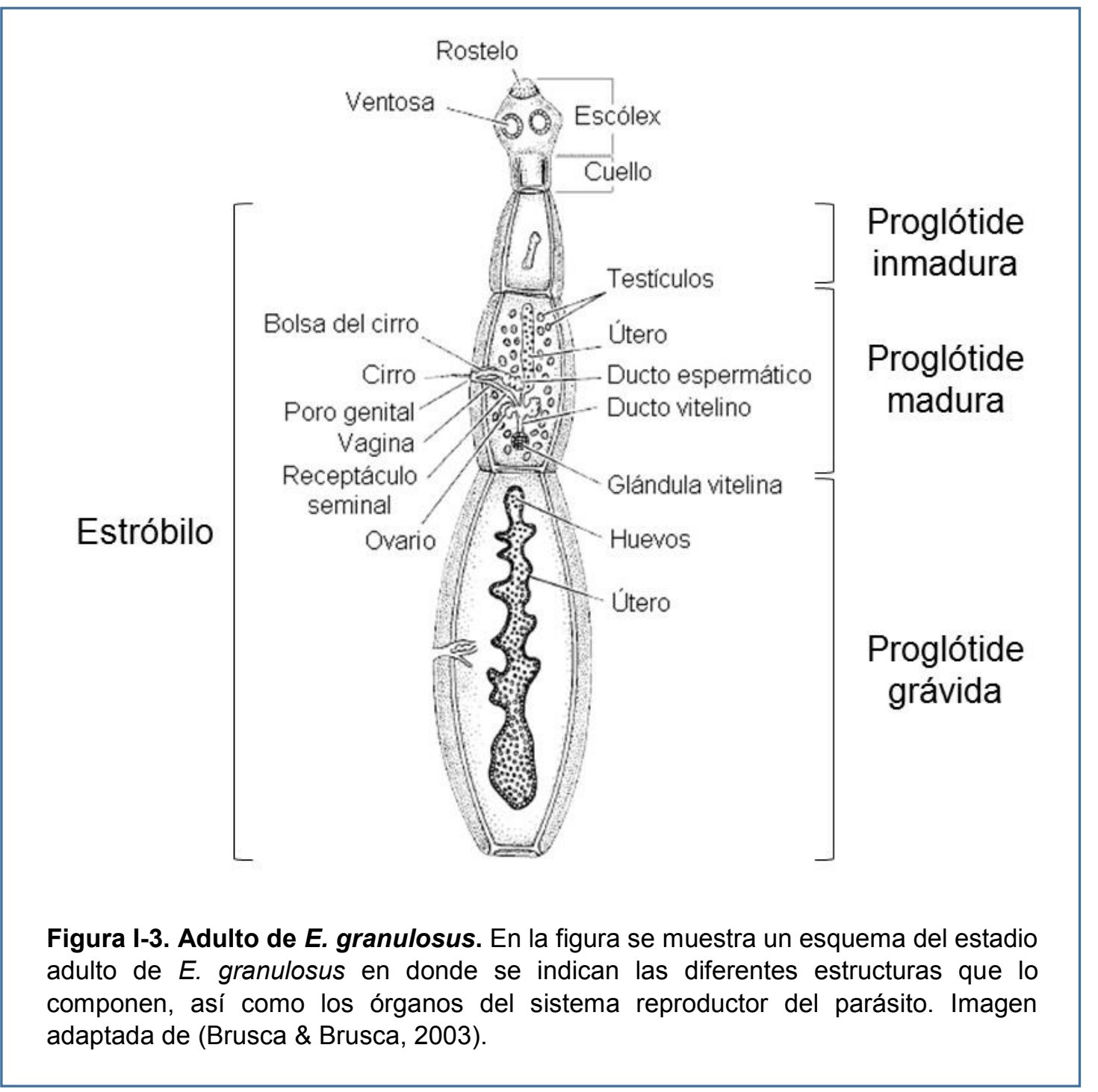

Otro aspecto que vale comentar en relación a la anatomía y fisiología del estadio adulto de E. granulosus, es la presencia de un sistema nervioso bien desarrollado, compuesto tanto por componentes centrales como periféricos. El sistema nervioso central consiste en un par de ganglios laterales ubicados dentro del escólex que se conectan mediante un anillo nervioso central y una comisura cerebral transversal. De la parte anterior de los ganglios laterales se extiende un par de nervios que se conectan con los ganglios rostelares, de los cuales parten a su vez nervios que inervan el rostelo armado. Los ganglios posterolaterales, a diferencia de los antes mencionados, se conectan sólo a través de nervios, que a su vez los vinculan también con los cordones nerviosos medianos. Las ventosas son inervadas por nervios provenientes de los ganglios laterales y posterolaterales, y de los cordones medianos. A partir 
de los ganglios laterales parte un conjunto de 10 cordones nerviosos, los dos cordones nerviosos laterales mayores, los cordones ventrolaterales, los dorsolaterales y dos pares de cordones nerviosos medianos. Los cordones laterales pasan por los ganglios posterolaterales antes de extenderse por el resto del cuerpo del parásito. A lo largo del recorrido de los nervios, los mismos se conectan a través de comisuras transversales. El sistema nervioso periférico se compone de plexos nerviosos que, sumados a los que inervan a las ventosas y el rostelo, se asocian a la musculatura subtegumentaria y elementos del sistema reproductor, entre otras estructuras (Brownlee et al., 1994).

En cuanto al sistema excretor, el mismo está compuesto por túbulos colectores que convergen en canales excretores que se extienden a lo largo del cuerpo del cestodo. Este sistema es de tipo protonefridial (Smyth \& McManus, 2007).

Existen también en el cuerpo del cestodo adulto capas musculares longitudinales y circulares que se encuentran por debajo del tegumento.

\subsubsection{Huevo}

Los huevos de Echinococcus spp. tienen forma ovoide y un tamaño que ronda los 30-40 $\mu$ m. Se caracterizan por tener una cápsula embrionaria muy fina que suele perderse al depositarse los huevos con las heces del animal hospedador. La ausencia de dicha protección se compensa mediante un engrosamiento del embrióforo, el cual está formado por bloques de queratina unidos por una sustancia cementante (Ver Figura I-4). Estas estructuras son las que le dan al huevo un aspecto estriado al observarlo al microscopio (Eckert et al., 2001; Smyth \& McManus, 2007). Cabe destacar que los huevos de Echinococcus spp. son altamente resistentes a diversos factores, pudiendo ser infectivos por largo tiempo si se encuentran en condiciones adecuadas de temperatura y humedad. Por ejemplo, huevos de E. multilocularis se han mantenido viables por 16 meses en agua a $4^{\circ} \mathrm{C}$. Por otra parte, el calor seco o el agua hirviendo son capaces de matar a los huevos de E. granulosus, y probablemente también a las otras especies del género; mientras que tanto los huevos de $E$. granulosus como los de $E$. multilocularis son altamente resistentes a temperaturas de congelación de alrededor de $-20^{\circ} \mathrm{C}$ (aunque a $-80^{\circ} \mathrm{C}$ sobreviven sólo unas $48 \mathrm{hs}$ ). Los huevos de estos cestodos son sensibles a la desecación, perdiendo viabilidad entre los 2 y 4 días con humedades relativas de alrededor de $25 \%$. Finalmente, con respecto a la resistencia frente a compuestos químicos desinfectantes, se ha observado que los huevos de $E$. granulosus conservan viabilidad luego de permanecer entre 5 y $60 \mathrm{~min}$ en etanol al $50 \%, 70 \%$ o $95 \%$, aunque casi no sobreviven al glutaraldehído al 5\% o 10\% (Eckert et al., 2001). 


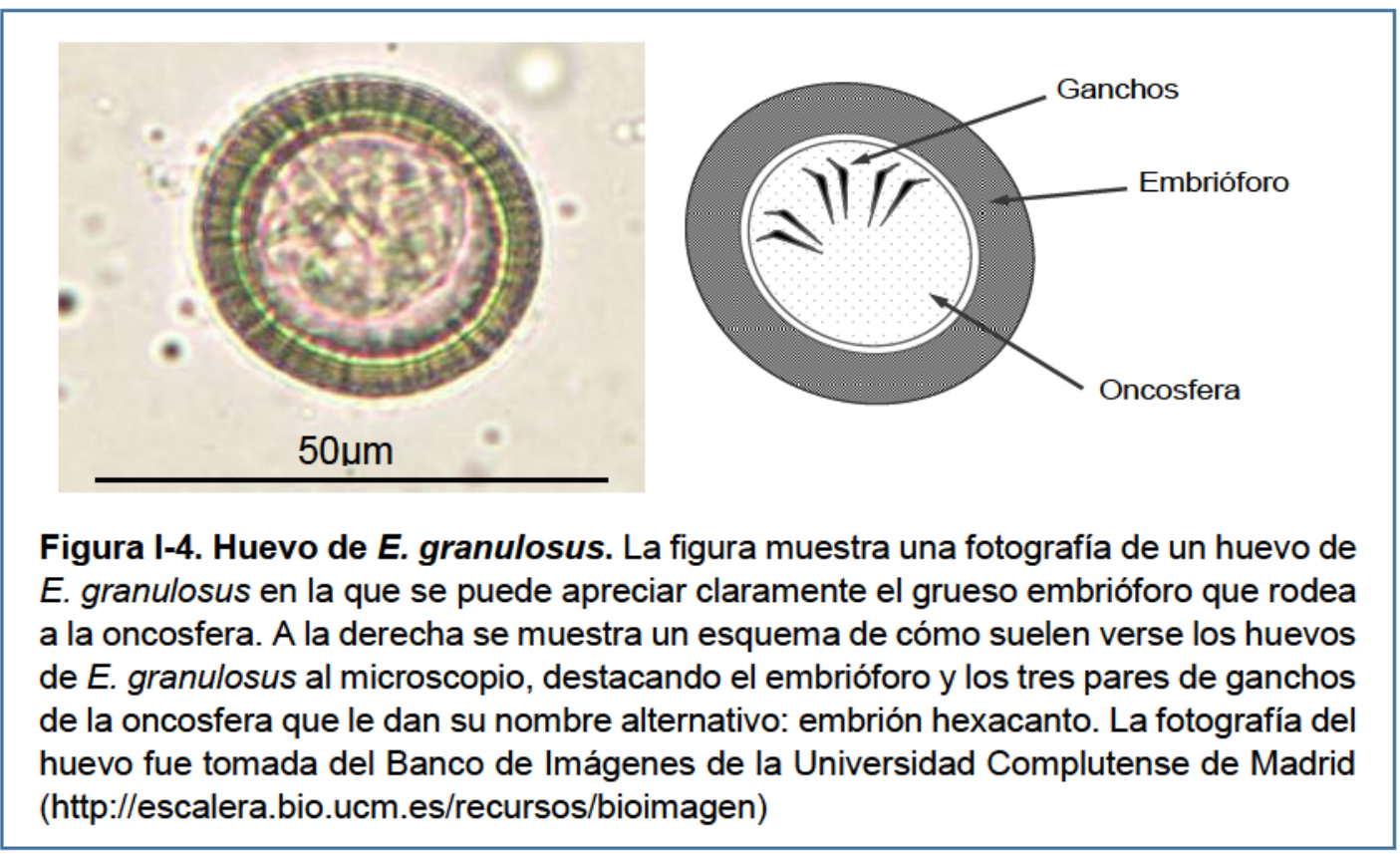

En el interior del huevo se localiza el embrión denominado oncosfera (o hexacanto). La estructura básica de la oncosfera consiste en un pequeño núcleo de células germinativas que darán origen al metacestodo, un par de glándulas de penetración, tres pares de ganchos accionados por un complejo sistema de músculos, un sistema nervioso primitivo y un fino epitelio que recubre lo antes mencionado, el cual posee también extensiones citoplasmáticas (Smyth \& McManus, 2007). Se han propuesto diversas funciones para las glándulas de penetración. Entre otras, se ha propuesto que sus secreciones podrían producir lisis de los tejidos del hospedador, que protegerían a la oncosfera del ataque del sistema inmune del animal al que está invadiendo o que podrían asistir en la adhesión previa a la penetración del tejido. Sin embargo, aún no es claro el rol de estas glándulas en el proceso de penetración del intestino del hospedador intermediario (Holcman \& Heath, 1997; Smyth \& McManus, 2007). En cuanto a los ganchos de este estadio de Echinococcus spp., se ha propuesto que los mismos podrían ayudar a romper los tejidos del hospedador, movilizados por la acción de los músculos presentes en la oncosfera (Holcman \& Heath, 1997).

Una vez atravesado el intestino del hospedador, la oncosfera alcanza la vena porta hepática y se traslada a través de la sangre hasta alcanzar el órgano blanco en el cual dará origen al metacestodo. Normalmente el sitio de establecimiento del metacestodo es el hígado o el pulmón, aunque muchas otras localizaciones son posibles.

\subsubsection{Metacestodo}

El metacestodo es el estadio larval de Echinococcus spp. que se desarrolla en los órganos internos de los animales que actúan como hospedadores intermediarios de dichos parásitos. 
Cabe recordar que es este estadio el responsable de las zoonosis que afectan al ser humano conocidas como hidatidosis (o echinococcosis) quística, causada por E. granulosus s.l.; hidatidosis (o echinococcosis) alveolar, causada por E. multilocularis; y las echinococcosis neotropicales causadas por E. oligarthra y E. vogeli. E. granulosus s.l. es también el agente causal de la hidatidosis en animales de producción ganadera, tales como ovejas, vacas y cerdos, por lo que afecta no sólo a la producción agropecuaria sino que incrementa las posibilidades de infección del ser humano, por mantener el ciclo doméstico entre el perro y el ganado.

A continuación se hará una descripción de las principales características del metacestodo de $E$. granulosus y se mencionaran luego las diferencias con los metacestodos de las otras especies del género.

El metacestodo de $E$. granulosus consiste en una estructura vesicular (o quística) turgente, con líquido en su interior (líquido hidático), que crece gradualmente aumentando su diámetro. Dicha vesícula se encuentra delimitada por una pared compuesta por una fina capa celular interna (capa germinativa); y una capa acelular externa (capa laminar), que puede llegar a medir unos 3 milímetros de espesor. El metacestodo suele estar rodeado por una tercera capa más externa, la capa adventicia. Ésta es generada por el hospedador como resultado de la resolución de la respuesta inflamatoria temprana inducida por la presencia del parásito en los tejidos del hospedador. El conjunto formado por el metacestodo y la capa adventicia se denomina quiste hidático (Ver Figura I-5).

Por brotación interna, la capa germinativa (CG) da origen a las vesículas prolígeras, las cuales a su vez generan protoescólices en su interior. La CG posee también un tegumento sincitial, con microtricos truncados, cuya cara apical se orienta hacia afuera del quiste; y otros tipos celulares como células musculares, de almacenamiento de glucógeno e indiferenciadas. Hacia el interior del quiste, las células de la CG no forman sincitio ni poseen complejos de unión, por lo que el líquido intercelular de la CG sería continuo respecto al líquido hidático (Díaz et al., 2011).

Tal como se mencionó previamente, entre la CG y el tejido del hospedador, se encuentra la capa laminar (LL). Esta estructura es una matriz extracelular especializada, que se encuentra únicamente en organismos del género Echinococcus. Su función está relacionada con mantener la integridad física del metacestodo, así como con proteger a las células de la CG del ataque del sistema inmune del hospedador. El gran espesor de la LL de E. granulosus ayudaría a mantener turgentes a los quistes hidáticos vivos, contrarrestando la presión ejercida desde el exterior del mismo. 
El entramado de fibrillas que conforman la LL está compuesto por mucinas (glicoproteínas altamente glicosiladas) y los carbohidratos que componen la LL son O-glicanos del tipo mucina. Por otra parte, en el caso de E. granulosus (pero no en E. multilocularis ni E. vogeli) existen depósitos de inositol-hexakisfosfato de calcio en la LL, aunque su función se desconoce (Díaz et al., 2011).

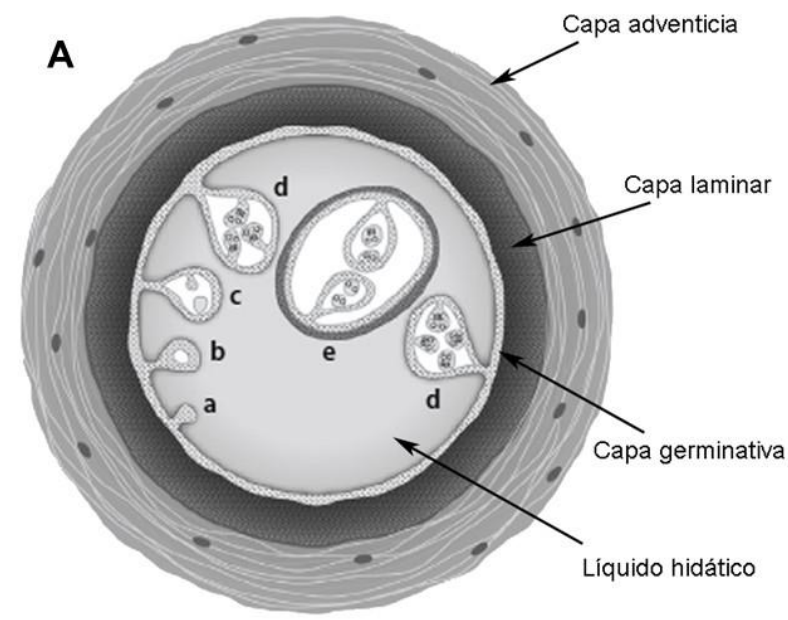

B

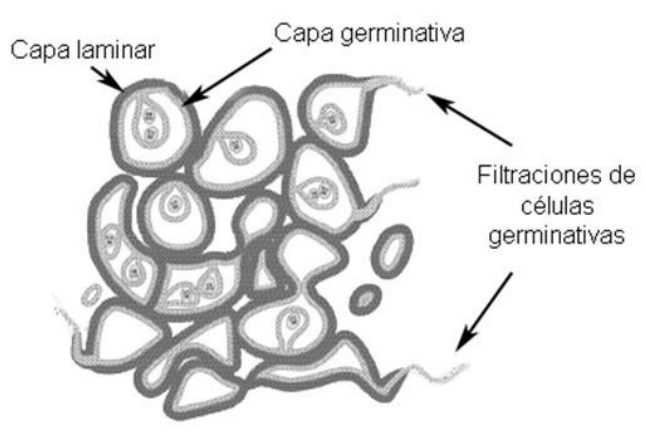

Figura I-5. Esquema de la estructura del metacestodo. En el panel (A) se observa un esquema del metacestodo de $E$. granulosus. Con las letras (a-d) se indican las etapas del proceso de generación de vesículas prolígeras y protoescólices. La letra (e) muestra un quiste hijo, con su propia LL. En el panel (B), por su parte, se esquematiza el desarrollo del metacestodo de E. multilocularis. Se pueden observar los elementos básicos del metacestodo como son la LL, la CG, las vesículas prolígeras y los protoescólices. Se destacan las filtraciones de células germinativas que permiten la metástasis del parásito. Este esquema ha sido adaptado a partir de (Thompson \& Jenkins, 2014).

Los metacestodos de las otras especies del género Echinococcus tienen una estructura similar al metacestodo de E. granulosus, pero presentan ciertas variaciones. E. vogeli y $E$. oligarthra se diferencian en que sus metacestodos tienden a formar quistes con múltiples cámaras, de allí que se llame hidatidosis poliquística a la enfermedad causada por estos cestodos en sus hospedadores intermediarios. En cuanto a E. multilocularis, su metacestodo se desarrolla (principalmente en el hígado) como una especie de laberinto de vesículas. A medida que crece, el metacestodo se infiltra en los tejidos del hospedador pudiendo incluso generar metástasis y originar focos de crecimiento del parásito en otros órganos, lo que hace que la hidatidosis alveolar sea una enfermedad mucho más agresiva y letal que la hidatidosis quística (Ver Figura I-5). Recientemente, se han descripto elementos musculares y nerviosos en la CG de E. multilocularis. Si bien el quiste es una estructura inmóvil y se desconoce qué función cumplirían las fibras musculares, se cree que estarían vinculadas con la invaginación de la CG en la formación de las vesículas prolígeras. En cuanto a las fibras nerviosas, se ha 
propuesto que podrían ser parte de un sistema neuroendócrino que regule el desarrollo de la larva de E. multilocularis (Koziol et al., 2013).

A diferencia de lo que ocurre en $E$. granulosus, la LL generada en los metacestodos de $E$. vogeli y E. multilocularis ronda los $400 \mu \mathrm{m}$ y los $10-12 \mu \mathrm{m}$ de espesor, respectivamente (Díaz et al., 2011).

\subsubsection{Protoescólex}

Los protoescólices se generan por brotación a partir de la CG, en un proceso clonal y asincrónico. Durante el desarrollo de los protoescólices, los mismos se encuentran unidos a la membrana germinativa mediante un tallo, o pedúnculo, del cual pueden liberarse una vez alcanzado su desarrollo completo. Morfológicamente, el protoescólex consiste en un escólex con un rostelo armado y cuatro ventosas, muy similar a lo que es el escólex del cestodo adulto, sólo que normalmente se encuentra invaginado en la parte posterior del cuerpo (Ver Figura I6). El sistema nervioso de los protoescólices se asemeja mucho al del cestodo adulto (Koziol et al., 2013). Por otra parte, en los protoescólices completamente desarrollados es evidente la presencia de corpúsculos calcáreos, que desaparecen al desarrollarse el adulto (Martínez et al., 2005).
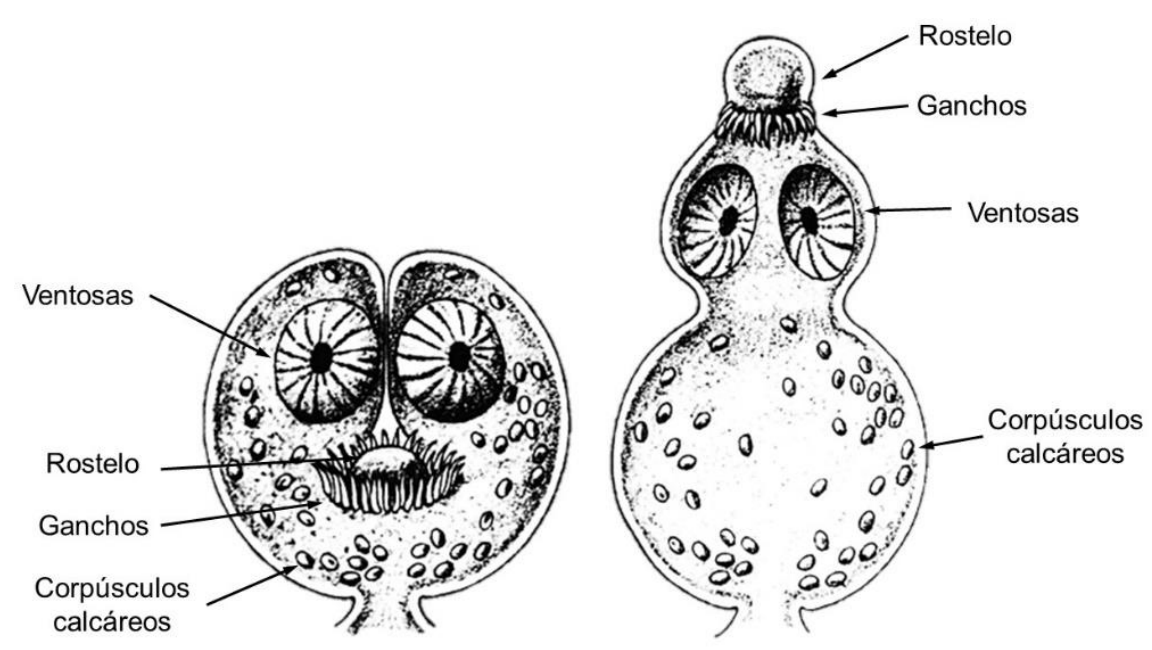

Figura I-6. Esquema de un protoescólex de E. granulosus. La figura muestra de forma esquemática la morfología de un protoescólex en su forma invaginada (izquierda) y evaginada (derecha). Como se puede observar, en la forma invaginada, tanto el rostelo como las ventosas se encuentran retrotraídas hacia la parte posterior del cuerpo del protoescólex. Las imágenes han sido obtenidas y adaptadas del centro de Recursos de Imágenes de Medicina Tropical.

(http://tmcr.usuhs.edu/tmcr/chapter3/epidemiology6.htm)

Como se mencionó al hablar del ciclo de vida de Echinococcus spp., los protoescólices son el estadio infectivo para los hospedadores definitivos. Al ser el metacestodo ingerido por un 
hospedador adecuado, se liberan los protoescólices, los cuales se evaginan, activados por enzimas digestivas, cambios de $\mathrm{pH}$, sales biliares, etc.; para finalmente desarrollarse al estadio adulto. No obstante, es muy importante destacar la gran plasticidad fenotípica que poseen los protoescólices. No sólo son capaces de desarrollarse hacia el estadio adulto al ser ingeridos por el hospedador definitivo, sino que, si se liberan del metacestodo (por ruptura del quiste) son capaces de desarrollar nuevos metacestodos en los órganos del hospedador intermediario.

\subsubsection{Distribución geográfica de la hidatidosis}

Si bien la hidatidosis quística tiene una distribución prácticamente global, existen ciertas regiones altamente endémicas para dicha parasitosis (Ver Figura I-7). Entre ellas se puede mencionar el cono sur de Sudamérica, el norte de África, el sur y este de Europa, la zona este del mar Mediterráneo, Siberia, Asia central y el oeste de China (Crompton, 2013). Es importante recordar que actualmente se ha determinado la existencia de varias especies causantes de hidatidosis quística, las cuales previamente eran consideradas cepas o genotipos de E. granulosus. Teniendo en cuenta ese escenario, es posible delinear la distribución geográfica de las diferentes especies, a saber: E. granulosus s.s. (Genotipo G1) está presente en Australia, Europa, Estados Unidos, Nueva Zelanda, África, Sudamérica y Rusia; E. granulosus s.s. (G2) en Tasmania y Argentina; E. granulosus s.s. (G3) en Asia; E. equinus (G4) en Europa, Oriente Medio y Sudáfrica; E. ortleppi (G5) en Europa, Sudáfrica, India, Rusia y Sudamérica; E. canadensis (G6/G7) en Europa, África y Sudamérica; E. canadensis (G8/G10) en América del Norte y el norte de Europa y Asia (Alvarez Rojas et al., 2014; Thompson \& McManus, 2002).

La hidatidosis alveolar, por su parte, se encuentra exclusivamente distribuida en el hemisferio norte, existiendo focos endémicos muy importantes en China, en donde se han registrado zonas con hasta un $5 \%$ de la población humana infectada. Asimismo, se ha detectado un aumento del número de casos reportados de hidatidosis alveolar en Suiza, que parecen estar relacionados con el aumento en la población de zorros (Torgerson et al., 2010).

En cuanto a la hidatidosis poliquística, producida por E. vogeli y E. oligarthra, se puede decir que su impacto en la salud humana es significativamente menor que el de las dos especies antes mencionadas. Dicha situación parece estar relacionada con el hecho de que los ciclos selváticos de los cestodos causantes de las echinococcosis neotropicales se encuentran prácticamente aislados de la población humana. No obstante, existe la posibilidad de que el riesgo aumente si los animales domésticos, principalmente perros y gatos, entran en contacto con los hospedadores intermediarios de $E$. vogeli y $E$. oligarthra (respectivamente). Dicha situación podría aumentar las probabilidades de infección de los 
pobladores de las regiones endémicas para estos cestodos, que abarcan zonas de América central y del sur donde habitan sus respectivos hospedadores (D'Alessandro \& Rausch, 2008).
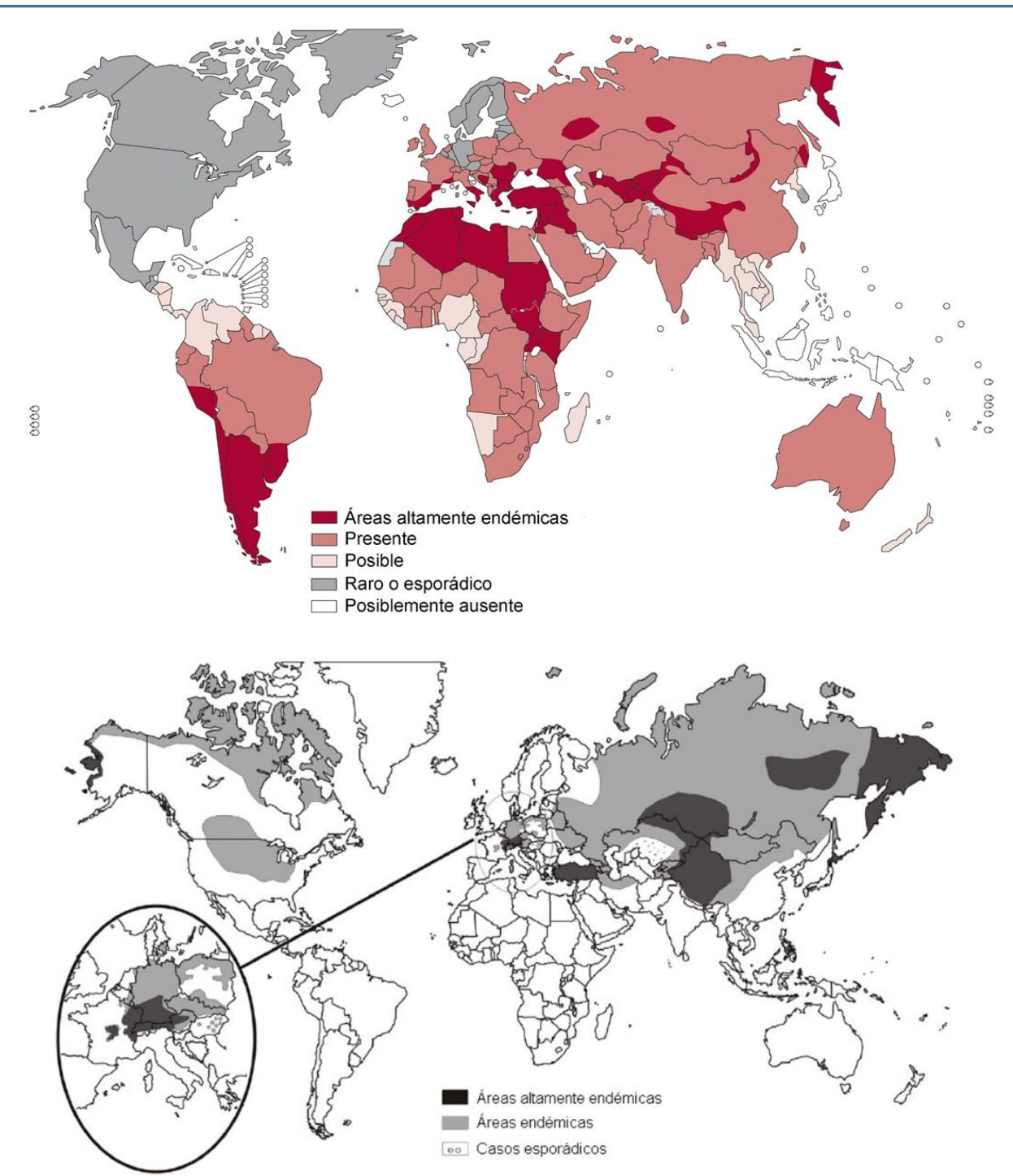

Figura 1-7. Distribución geográfica de la hidatidosis quística y alveolar. En el mapa superior se muestran las zonas geográficas donde se puede encontrar la hidatidosis quística, causada por $E$. granulosus s.l. Se destacan regiones altamente endémicas en Sudamérica, África, parte de Europa y Asia. La imagen fue adaptada del sitio web de la Organización Mundial de la Salud, y corresponde a la distribución de la hidatidosis del año 2011 (http://www.who.int/echinococcosis/en/). En el mapa inferior se muestra la distribución geográfica de la hidatidosis alveolar. Se destacan regiones altamente endémicas en Europa central, Rusia, Turquía y China. La imagen fue adaptada a partir de (Torgerson et al., 2010) 


\subsubsection{Importancia de la hidatidosis quística en nuestra región}

Teniendo en cuenta los posibles hospedadores intermediarios de E. granulosus s.l. y la importancia de las actividades ganaderas en los países de la región, no sorprende que tanto Argentina, como Uruguay, Brasil y Chile representen una zona altamente endémica para la hidatidosis.

En el caso de Argentina, la hidatidosis está distribuida prácticamente en todo el territorio nacional, con mayor prevalencia en zonas rurales y, en particular, en regiones de cría de ganado ovino y caprino, aunque también afecta regiones de cría de ganado bovino y porcino. Se calcula que el ciclo zoonótico de E. granulosus se localiza en un $30 \%$ del territorio argentino, lo que representa un área endémica de cerca de $1.211 .912 \mathrm{~km}^{2}$. No obstante, la distribución no es uniforme en todo el territorio, sino que existen provincias afectadas en toda su extensión y otras sólo parcialmente (Ver Figura 1-8). Los mayores focos endémicos de hidatidosis en Argentina se localizan en las Áreas: Patagónica (Tierra del Fuego, Santa Cruz, Chubut, Río Negro y Neuquén), de la Pampa Húmeda (Provincia de Buenos Aires, sur de Santa Fe y Córdoba), Mesopotámica (territorio de Corrientes, al sur del río Corrientes, y norte de Entre Ríos hasta el eje La Paz, Federal y Concordia), Cuyana (Provincia de Mendoza y oeste de San Juan), Mediterránea (parte de las provincias de Córdoba, Santiago del Estero, San Luis, La Rioja, Catamarca y San Juan), y de Alta Montaña del Noroeste (Tucumán, Salta, Jujuy y noroeste de Catamarca) (Moral, 2012).

Los análisis de los genotipos (algunos de ellos considerados hoy especies diferentes) de E. granulosus presentes en el territorio argentino han podido identificar la presencia de G1 y G2 (E. granulosus s.s.), G5 (E. ortleppi), G6 y G7 (E. canadensis). Dado que los análisis de genotipificación no se han realizado con fines epidemiológicos, sino que se efectuaron a muestras recolectadas en hospitales de alta complejidad y/o mataderos rurales, por solicitud de estos, no se han podido calcular prevalencias e infectividades por especies (Guarnera, 2009). De hecho, de esos estudios parecía desprenderse que el genotipo $G 7$ no era infectivo para el humano, y recientemente se ha establecido que hay infecciones humanas causadas por E. canadensis (G7) en diversos países (Alvarez Rojas et al., 2014).

Desde el punto de vista de la salud pública, la hidatidosis es un problema grave en las zonas endémicas, especialmente en aquellas vinculadas a actividades agroganaderas, y más aún en zonas de bajos recursos. La hidatidosis es una enfermedad crónica, que no sólo puede ser mortal, sino que puede generar diversos grados de discapacidad que varían tanto en gravedad como en duración. La gravedad de la enfermedad varía mucho de acuerdo a la localización del quiste hidático. Por ejemplo, los quistes hepáticos suelen ser asintomáticos durante mucho tiempo, aun cuando desarrollen un tamaño importante, mientras que los quistes cerebrales $\mathrm{u}$ oculares pueden traer grandísimas complicaciones incluso siendo 
pequeños; esto explica por qué los quistes intracerebrales suelen detectarse en niños, mientras que los hepáticos se registran a edades más avanzadas (Moro \& Schantz, 2009).

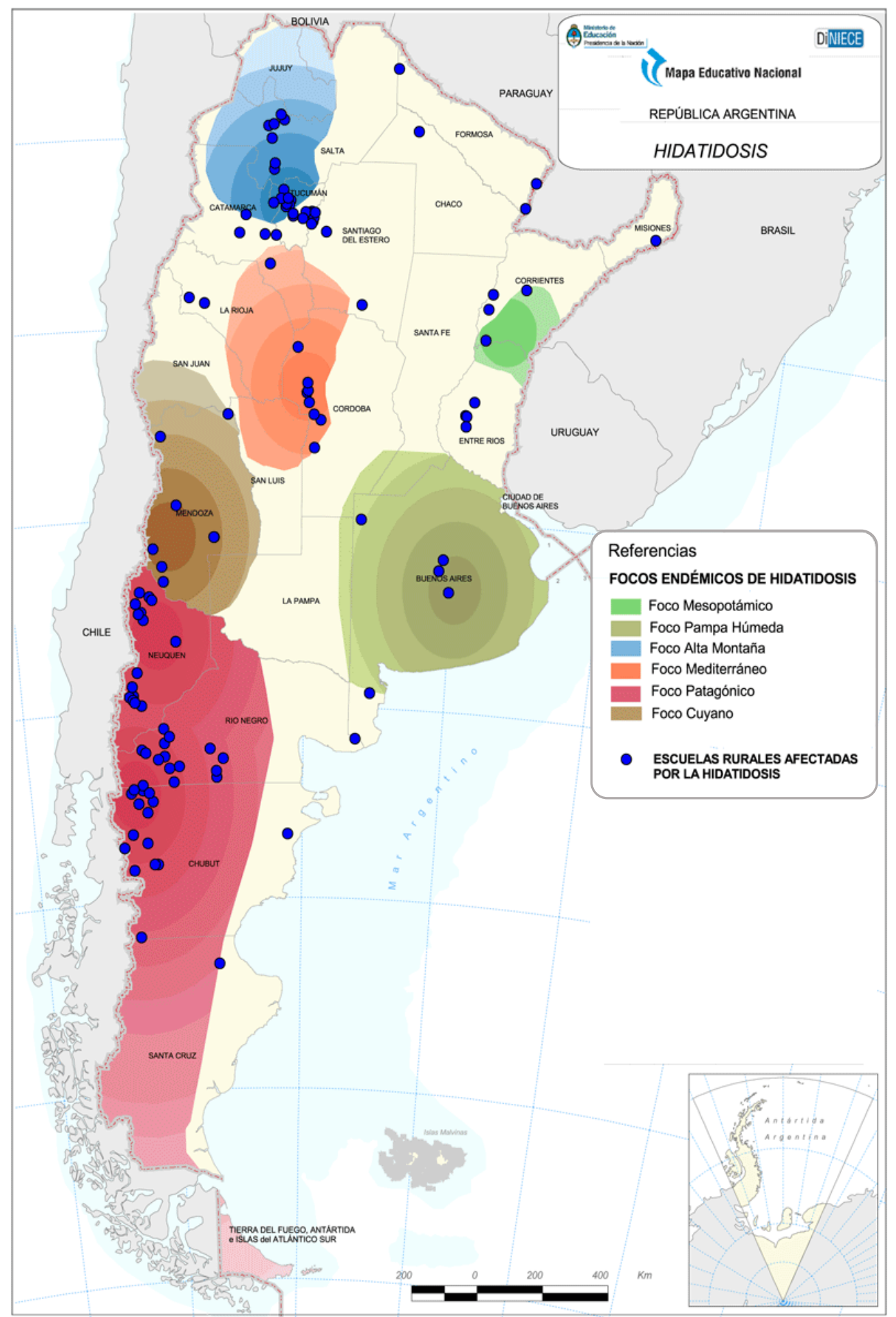

Figura I-8. Principales focos de hidatidosis quística en Argentina. La figura muestra la distribución de la hidatidosis en la República Argentina, destacando los principales focos de la enfermedad. Los puntos azules indican la ubicación de las escuelas rurales que señalaron que la hidatidosis es una problemática presente en su comunidad (relevamiento 2006-2009). El mapa fue adaptado de la página web del Programa Nacional Mapa Educativo del Ministerio de Educación de la Nación (http://www.mapaeducativo.edu.ar/Atlas/Hidatidosis) 
En cuanto al impacto económico de la hidatidosis quística en la región, se ha estimado que las perdidas monetarias debidas a la infección del ganado oscilarían aproximadamente entre los 44 y 66 millones de dólares anuales. Haciendo correcciones por la estimación de casos no reportados, las perdidas rondarían entre los 77 y 115 millones de dólares. Estas pérdidas se deben al decomisado de hígados infectados, la disminución en la producción de carne, leche, lana y de la fecundidad de los animales enfermos, entre otros factores. Por su parte, las estimaciones de pérdidas económicas anuales por hidatidosis quística en humanos oscilan entre los 15 y 30 millones de dólares, dependiendo de los métodos aplicados para realizar el cálculo. Para estimar las pérdidas monetarias por la enfermedad en humanos se consideran tanto los gastos de tratamientos como la pérdida de salarios relacionada a la incapacidad que genera en algunos casos la enfermedad (Irabedra \& Roig, 2007).

En varios de los países de la región existen, o existieron, programas de control y vigilancia de la hidatidosis, tendientes a reducir la prevalencia de la enfermedad. Muchos de ellos se han basado en la administración de drogas antihelmínticas (Praziquantel) a los perros de regiones altamente endémicas ocho veces al año, con la finalidad de evitar que el parásito llegara a su estado grávido y pudiera esparcir sus huevos en el ambiente. Estos programas enfrentan, sin embargo, graves complicaciones para poder llegar a ser completamente exitosos. Los mismos tienen amplios requerimientos de vehículos y recursos humanos para lograr desparasitar ya sea a grandes poblaciones de perros, o poblaciones pequeñas pero muy dispersas. Sumado a eso, los accesos a las zonas de mayor prevalencia de hidatidosis muchas veces son bastante precarios, dificultando aún más las tareas de control. No obstante las complicaciones técnicas, han habido algunos avances en el control de la hidatidosis en ciertas regiones, como Uruguay y las provincias argentinas de Tierra del Fuego, Neuquén y Río Negro. En algunos casos, aunque la enfermedad siga afectando al ganado y los perros permanezcan parasitados, se ha logrado disminuir la prevalencia de la hidatidosis en humanos mediante programas de educación sanitaria, detección y tratamiento temprano de los infectados. Cabe destacar que el más grande desafío que deben vencer los programas de control, aparte de las complicaciones técnicas y logísticas, es la continuidad en el tiempo, ya sea por decisiones económicas y/o políticas. En regiones de Chile, por ejemplo, se han suspendido programas de control de la hidatidosis que estaban progresando con éxito (Larrieu \& Zanini, 2012).

Recientemente, en la Provincia de Río Negro, se ha realizado una prueba de campo, en ovejas, de la vacuna EG95. Esta vacuna se basa en una proteína recombinante de la oncosfera de E. granulosus (Jabbar et al., 2011). Los resultados han sido prometedores, y han mostrado protección frente a la infección por E. granulosus en animales de hasta tres años. No obstante, aún se requieren más estudios que confirmen que los animales se mantienen protegidos durante toda su vida productiva (Larrieu et al., 2013). Cabe destacar 
que si bien la aplicación de la vacuna EG95 no está exenta de complicaciones técnicas, de infraestructura y económicas, la misma representa una herramienta más en la lucha contra la hidatidosis.

\subsubsection{Diagnóstico y tratamiento de la hidatidosis}

El diagnóstico de hidatidosis se lleva a cabo mediante examen clínico, diagnóstico por imágenes y serología. En las etapas iniciales del desarrollo de la hidatidosis normalmente no se presentan síntomas, razón por la cual la hidatidosis suele diagnosticarse en adultos en los que el/los quiste/s han crecido durante varios años. La aparición de los síntomas puede variar mucho dependiendo de cuál sea el órgano afectado y de la posición y tamaño del quiste en dicho órgano. Asimismo, pueden surgir complicaciones debidas a rupturas del quiste que pueden generar infecciones secundarias en otros tejidos del hospedador (debido a la plasticidad fenotípica antes mencionada de los protoescólices). La ruptura del quiste puede provocar también reacciones anafilácticas y otras complicaciones sumamente peligrosas para la salud.

Una de las herramientas más útiles para el diagnóstico de la hidatidosis es la ecografía, la cual permite el diagnóstico, clasificación (existe un sistema estandarizado de clasificación por ecografía de los quistes hidáticos, establecido por la Organización Mundial de la Salud) y seguimiento de los quistes, aunque la sensibilidad es baja para quistes de pequeño tamaño. Otras técnicas de imágenes, como la resonancia magnética y la tomografía, son usadas también para el diagnóstico.

Las pruebas serológicas constituyen también una herramienta útil para el diagnóstico y seguimiento de la hidatidosis. No obstante, a pesar de su uso muy difundido, aún existen dudas sobre su eficacia, ya que la misma parece variar con la localización, tamaño y estado del quiste. Asimismo, se ha reportado reacción cruzada con antígenos propios de otras helmintiasis, cirrosis hepáticas y ciertos tipos de cáncer, lo cual pone en duda su especificidad.

Respecto al tratamiento de la hidatidosis quística, existen cuatro posibilidades, dependiendo del estado de los quistes: cirugía, esterilización percutánea, tratamientos con drogas u observación.

La cirugía es el tratamiento más habitual y, si bien suele ser efectivo, no garantiza que no se produzca recurrencia. Se aplica a quistes grandes, a quistes infectados, propensos a ruptura o localizados en órganos importantes. Por otra parte, es más difícil de aplicar en pacientes con múltiples quistes en diversos órganos.

Las técnicas de esterilización percutánea incluyen a PAIR (Punción, aspiración, inyección y reaspiración), que destruye la capa germinativa del quiste; y cateterismos modificados, que remueven la totalidad del quiste. La técnica de PAIR involucra una punción percutánea del 
quiste (asistida por ultrasonido), la aspiración del contenido, inyección de algún protoescolicida adecuado, y reaspiración luego de 15 a 20 minutos. Un choque anafiláctico es un posible riesgo de aplicar esta técnica. Este tratamiento se acompaña de administración de drogas antihelmínticas para prevenir quistes secundarios.

Los fármacos antiparasitarios que se utilizan para el tratamiento de la hidatidosis se conocen como benzimidazoles, en particular se utilizan el mebendazol y el albendazol, siendo este último el más usado actualmente. Estas drogas son más efectivas para el tratamiento de quistes pequeños, no siendo útiles para tratar quistes de más de $10 \mathrm{~cm}$ de diámetro. Los benzimidazoles poseen también efectos secundarios no deseados asociados a su uso prolongado.

Finalmente, en algunos casos de quistes no complicados, se opta por la estrategia de observación, ya que muchas veces los quistes terminan calcificándose y volviéndose totalmente inactivos, sin generar inconvenientes mayores.

En el caso de E. multilocularis, las posibilidades de tratamiento se reducen a la cirugía (con administración posterior de drogas para prevenir recurrencias), o bien a la administración por largos períodos de benzimidazoles, para los casos que no pueden ser operados. Estas drogas inhiben la proliferación de la larva, pero no la matan. En casos terminales de hidatidosis alveolar se han llevado a cabo trasplantes hepáticos, pero el uso de inmunosupresores asociado a este tipo de intervenciones puede estimular el crecimiento del parásito en caso de no haberse removido por completo (McManus et al., 2012).

De lo antes mencionado se desprende claramente que, a pesar de los avances obtenidos en la lucha contra la hidatidosis, aún resta mucho por hacer en lo que respecta al diagnóstico y tratamiento de la enfermedad. Sobre todo teniendo en cuenta que algunas de las alternativas existentes, aunque eficaces, requieren de una gran infraestructura para ser llevadas a cabo o poseen costos muy elevados, siendo que las personas más vulnerables a esta enfermedad suelen ser las de menores recursos. Por ejemplo, la técnica PAIR debe ser llevada a cabo por equipos altamente capacitados, capaces de lidiar con un choque anafiláctico. Asimismo, el costo de los benzimidazoles y las preocupaciones respecto a su eficacia hacen que se necesiten nuevas drogas para tratar esta enfermedad (McManus et al., 2012).

Debe tenerse en cuenta que para poder llevar a cabo el desarrollo de drogas específicas contra la hidatidosis que reduzcan el uso de terapias invasivas, es de suma necesidad ampliar nuestro conocimiento en lo que respecta a la biología del parásito, los factores que favorecen su establecimiento, su relación con el hospedador y otras variables que permitan interrumpir su desarrollo, y por consiguiente, el de la enfermedad. 


\subsection{Metabolismo de Echinococcus spp. y otros cestodos}

El profundizar en el conocimiento del metabolismo de los cestodos no sólo es importante, e interesante, desde el punto de vista básico, sino que de él pueden llegar a desprenderse estrategias que permitan intervenir en el establecimiento y desarrollo de estos parásitos en sus hospedadores, y por ende contribuir al control de la hidatidosis y el impacto que ella genera sobre la salud de la población. A continuación se hará una descripción de algunos aspectos del metabolismo general de los cestodos que ayudarán a comprender el motivo por el cual resulta de interés el estudio de las FABPs de estos organismos. Cabe destacar que la información disponible acerca del metabolismo de los cestodos ha surgido del estudio de diversas especies, principalmente de Hymenolepis diminuta. No obstante, se ha visto que algunas vías estudiadas también en otros cestodos (incluyendo Echinococcus spp.) se asemejan notablemente a las de $H$. diminuta e inclusive a las de parásitos trematodos como Fasciola hepatica y Schistosoma mansoni. Esto quizás se deba al hecho de que, esencialmente, todos los platelmintos mencionados están perfectamente adaptados a su estilo de vida parasitario, por lo que muchas de sus adaptaciones resultan ser comunes a las diferentes especies.

\subsubsection{Metabolismo general y obtención de energía}

Hasta el momento es ampliamente aceptado el concepto de que la fuente de energía por excelencia de los platelmintos parásitos son los hidratos de carbono, siendo el glucógeno la forma de almacenamiento de los mismos. Estas reservas le permiten a los parásitos subsistir durante las etapas de sus ciclos de vida en las que se encuentran fuera del hospedador (huevos, en el caso de Echinococcus), así como durante los períodos de ayuno del hospedador, en los que la concentración de glucosa en el intestino son bajas, como se ha determinado para H. diminuta (Maule \& Marks, 2006).

Respecto a los mecanismos utilizados para la obtención de energía, se considera que los estadios de vida libre de los parásitos utilizan vías aeróbicas para catabolizar las reservas endógenas de las cuales se suplieron mientras se encontraban en su hospedador. El camino seguido para la degradación de las reservas de glucógeno consiste en la vía clásica de glucólisis de Embden-Meyerhof, la oxidación de piruvato a acetil-coenzima A (acetil-CoA) dentro de las mitocondrias por acción del complejo de la piruvato deshidrogenasa, y la posterior oxidación del acetil-CoA a $\mathrm{CO}_{2}$ mediante las reacciones del ciclo de Krebs. EI ATP es formado, en su mayor parte, por fosforilación oxidativa acoplada a la cadena de transporte 
de electrones mitocondrial, aunque obviamente existen también reacciones donde se produce ATP por fosforilación a nivel de sustrato (Maule \& Marks, 2006; Smyth \& McManus, 2007).

En el caso de los parásitos adultos, los mismos no degradan los hidratos de carbono hasta $\mathrm{CO}_{2}$, sino que generan una cierta variedad de compuestos (dependiendo de qué especie se trate) como resultado de procesos fermentativos. Existen dos vías fermentativas principales: la glucólisis anaeróbica y la dismutación del malato.

La glucólisis anaeróbica, la cual genera lactato como producto final y rinde 2 ATP por molécula de glucosa, se lleva a cabo por la vía clásica de Embden-Meyerhof. E. granulosus se encuentra dentro del grupo de parásitos que libera una cantidad considerable de lactato. Si bien todos los platelmintos parásitos utilizan en cierta medida la glucólisis anaeróbica, en la mayoría de los casos es la otra vía (dismutación del malato) la que resulta de mayor relevancia.

En la vía de dismutación del malato, se degrada la glucosa, vía glucólisis, hasta fosfoenolpiruvato (PEP). Luego, el PEP es carboxilado por acción de la enzima PEP carboxiquinasa (PEPCK, por sus siglas en inglés) a oxalacetato, el cual es luego reducido a malato. El malato es transportado a la mitocondria, en donde una porción del malato se oxida a acetato y otra se reduce a succinato, pudiendo formarse luego, en algunas especies, propionato. En la rama oxidativa de esta vía, el malato pasa a piruvato por acción de la enzima málica, y luego el piruvato se oxida a acetil-CoA por acción del complejo de la piruvato deshidrogenasa, que estaría adaptado, en los helmintos parásitos, a actuar en condiciones anaeróbicas. En algunos parásitos se ha determinado que el acetil-CoA pasa luego a acetato mediante la acción de una enzima llamada acetato:succinato CoA-transferasa (ASCT). EI succinil-CoA generado por la ASCT pasa luego a succinato, y genera energía en forma de ATP (o GTP) por acción de la enzima succinil-CoA sintetasa (la misma que normalmente forma parte del ciclo de Krebs). Teniendo en cuenta que la dismutación del malato es una vía fermentativa, el balance neto de poder reductor debe ser nulo, por lo que el NADH generado en la oxidación del malato a acetato debe reoxidarse. Para ello, parte del malato es reducido a succinato por una serie de reacciones que revierten, en parte, algunas de las reacciones del ciclo de Krebs. La proporción de succinato:acetato debe ser de 2:1 para mantener el balance redox. La reducción de fumarato a succinato, catalizada por la fumarato reductasa (que forma parte de una cadena de transporte de electrones), está asociada a la síntesis de ATP. Para poder reducir fumarato a succinato, estos organismos cuentan además con una quinona (diferente a la ubiquinona de la cadena de transporte de electrones "convencional") denominada rodoquinona. Algunos platelmintos parásitos metabolizan el succinato obtenido por esta vía hasta propionato, siguiendo el camino inverso al que se produce en otros organismos para formar succinil-CoA a partir de propionil-CoA, por ejemplo en la degradación de ácidos grasos con número impar de carbonos. Este no parece ser el caso para 
Echinococcus, el cual se ha reportado que excreta succinato y acetato, aparte de lactato, tanto en condiciones aeróbicas como anaeróbicas (Maule \& Marks, 2006; Smyth \& McManus, 2007). La degradación anaeróbica de la glucosa hasta propionato y acetato, mediante la vía de dismutación del malato que se da en algunos platelmintos parásitos, genera unas 5 moléculas de ATP por molécula de glucosa. Este rendimiento energético es mayor que el alcanzado mediante la glucólisis anaeróbica hasta lactato, que genera 2 ATP por molécula de glucosa. Algunos estudios han demostrado que el estadio larval de E. granulosus posee la vía de las pentosas y que alrededor de un $20 \%$ de la glucosa utilizada in vitro por este organismo sería a través de esta vía (Smyth \& McManus, 2007).

Como se ha dicho antes, los platelmintos parásitos dependerían exclusivamente de los hidratos de carbono como sustratos para obtención de energía. Si bien los estadios de vida libre, en teoría, tendrían capacidad aeróbica y la posibilidad de oxidar ácidos grasos, esto no ha podido ser demostrado. Por otra parte, los aminoácidos no parecen hacer una contribución importante a la obtención de energía por parte de estos organismos, aunque sí son necesarios para la síntesis de sus proteínas (Maule \& Marks, 2006).

Respecto a los nucleótidos, se ha observado que algunos cestodos son capaces de sintetizar pirimidinas de novo, aunque los nucleótidos purínicos deberían ser incorporados a partir del hospedador. Las purinas libres pueden incorporarse por vías de salvataje (Smyth \& McManus, 2007).

En cuanto a los lípidos, la mayoría de estos compuestos no pueden ser sintetizados de novo por los cestodos, por lo que dependen de los hospedadores para adquirir estos nutrientes fundamentales.

Recientemente, con la publicación de los genomas de E. granulosus y E. multilocularis, se ha obtenido mayor información que respalda lo observado previamente. Entre otras, las vías de síntesis y degradación de muchos lípidos estarían ausentes en estos organismos, así como muchas de las vías de síntesis de aminoácidos y nucleótidos (Tsai et al., 2013; H. Zheng et al., 2013).

A continuación se presenta una descripción un poco más detallada del conocimiento actual sobre el metabolismo lipídico de los cestodos.

\subsubsection{Metabolismo de lípidos}

Desde el punto de vista energético, como se ha dicho, los lípidos no serían un sustrato importante en los platelmintos parásitos. No obstante, dadas las múltiples funciones que poseen los lípidos en las células, se hará una breve descripción de la información disponible respecto al metabolismo de estos compuestos. 
Tal vez la función más evidente de los lípidos sea la de formar las membranas biológicas que delimitan a las células y sus compartimentos intracelulares, siendo el colesterol y los fosfolípidos los principales componentes lipídicos de las mismas. Estos compuestos no son sintetizados de novo por los platelmintos parásitos, sino que son obtenidos directamente a partir del hospedador (colesterol) o formados a partir de precursores más simples obtenidos también del hospedador (ácidos grasos y grupos polares para la síntesis de fosfolípidos).

Estudios en E. granulosus han revelado que, si bien este parásito posee algunas enzimas de la vía del mevalonato, el mismo es incapaz de sintetizar colesterol. Se supone que los platelmintos parásitos utilizarían dicha vía para la síntesis de quinonas (como la rodoquinona) e isoprenoides para prenilación de proteínas, o bien con funciones hormonales (Digenis et al., 1970; Frayha, 1974; Maule \& Marks, 2006; Smyth \& McManus, 2007). Se ha observado también actividad esterasa en protoescólices de E. granulosus (Digenis et al., 1970), y se ha demostrado que el mismo es capaz de captar colesterol radiactivo a partir del hospedador en infecciones secundarias (Frayha, 1968). Se cree, por lo tanto, que dicho nutriente podría incorporarse en forma de ésteres de colesterol y luego ser liberado dentro de los tejidos parasitarios (Digenis et al., 1970).

En algunos cestodos se han observado gotas lipídicas en las células del tegumento. Se cree que las mismas contendrían depósitos de lípidos para síntesis de membrana, ya que, como se dijo previamente, los lípidos no serían un sustrato para obtención de energía en estos organismos (Smyth \& McManus, 2007).

En lo que respecta a los ácidos grasos, los cestodos son incapaces de sintetizarlos de novo a partir de acetil-CoA. Sólo pueden elongar ácidos grasos obtenidos a partir del hospedador. Si bien la elongación de los ácidos grasos ocurriría por adición secuencial de moléculas de acetil-CoA, se desconoce el mecanismo por el cual esto ocurre. En algunas especies de cestodos se ha detectado síntesis de prostaglandinas. Estos lípidos inmunomoduladores derivan de ácidos grasos insaturados de cadena larga, y podrían estar involucrados en la defensa de estos parásitos frente al ataque del sistema inmune del hospedador (Smyth \& McManus, 2007).

Los fosfolípidos, como se mencionó previamente, parecen ser sintetizados en cestodos a partir de ácidos grasos y grupos polares obtenidos a partir del hospedador. Por lo demás, la síntesis de fosfolípidos en cestodos no parece tener particularidades que los diferencien en gran medida de otros organismos (Maule \& Marks, 2006; Smyth \& McManus, 2007). En E. granulosus, los fosfolípidos principales son fosfatidilcolina, fosfatidiletanolamina y fosfatidilinositol (Frayha et al., 1980). En la Figura l-9 se muestra un esquema de las vías descriptas.

Frente a este panorama, y teniendo en cuenta su estilo de vida parasitario, resulta natural pensar en que los cestodos, y Echinococcus spp. en particular, deben haber desarrollado 
mecanismos para la obtención de los compuestos hidrofóbicos que toman de sus hospedadores. Asimismo, dada la insolubilidad en agua de los lípidos, Echinococcus spp., al igual que otros organismos, debe depender de proteínas de unión a lípidos que le permitan transportarlos y distribuirlos entre sus tejidos o dentro de sus células. En relación a este aspecto, en cestodos se han descripto dos familias de proteínas de unión a lípidos: las FABPs, y las proteínas que unen ligandos hidrofóbicos (HLBPs, por sus siglas en inglés). De estas

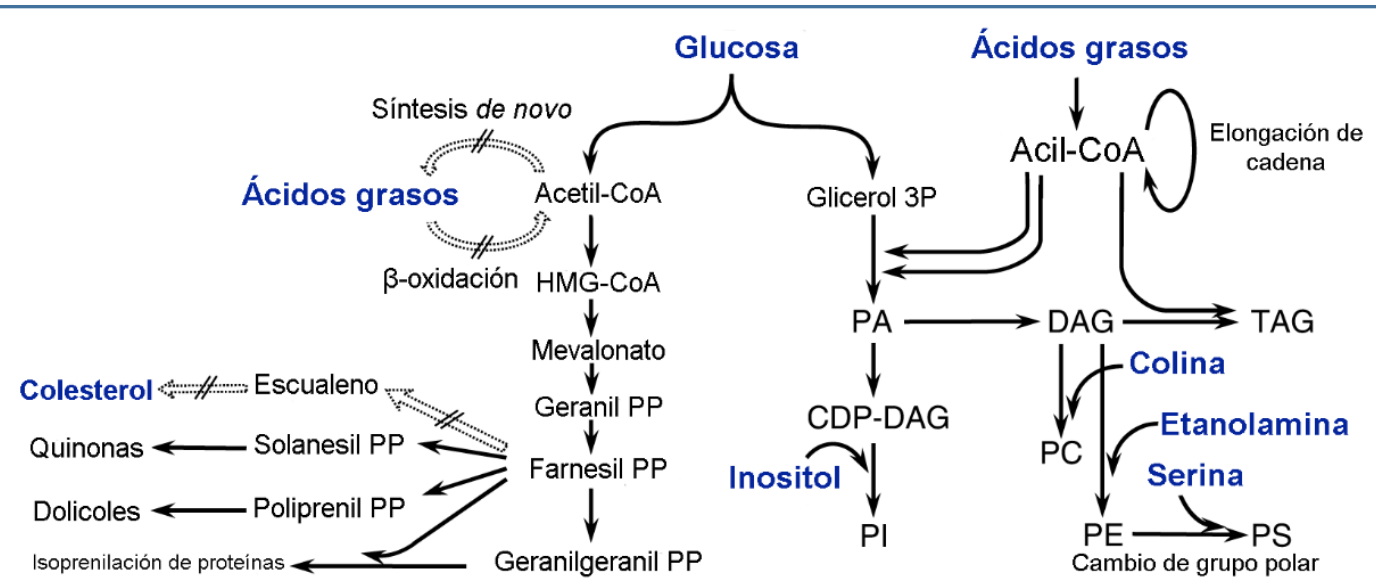

Figura 1-9. Metabolismo lipídico en cestodos. El esquema muestra un resumen del metabolismo lipídico en cestodos. Las flechas blancas interrumpidas indican vías ausentes en estos organismos, mientras que las negras simbolizan las vías presentes. Dada la capacidad biosintética limitada de los cestodos, algunos lípidos complejos sólo pueden ser sintetizados a partir de compuestos más simples obtenidos a partir del hospedador (marcados en azul). HMGCoA: hidroximetilglutaril-coenzima A; PP: pirofosfato; PA: ácido fosfatídico; CDP-DAG: citidinadifosfato-diacilglicéridos; PI: fosfatidilinositol; DAG: diacilglicéridos; TAG: triacilglicéridos; PC: fosfatidilcolina; PE: fosfatidiletanolamina; PS: fosfatidilserina.

Figura adaptada de (Maule \& Marks, 2006).

dos familias de proteínas, la de las HLBPs es exclusiva de cestodos, mientras que la de las FABPs se encuentra ampliamente representada en el reino animal. A continuación se hará una descripción de las características principales de las mismas.

\subsection{Proteínas que unen ligandos hidrofóbicos (HLBPs)}

La familia de las HLBPs está compuesta por un conjunto de proteínas específicas de cestodos dentro de las cuales se pueden considerar dos clases, las HLBPs intracelulares y las HLBPs secretadas al medio extracelular. Dentro del primer grupo se pueden mencionar MeHLBP descripta en Moniezia expansa y H-HLBP, de Hymenolepis diminuta; mientras que 
TsHLBP de Taenia solium y el Antígeno B (EgAgB) de E. granulosus pertenecen a las HLBPs que poseen secuencias señales de secreción (Alvite \& Esteves, 2012).

Las HLBPs son lipoproteínas de alto peso molecular cuya fracción proteica está compuesta por subunidades monoméricas ricas en a-hélices de entre 7 y $11 \mathrm{kDa}$ aproximadamente. Estas lipoproteínas son muy abundantes en cestodos y son altamente inmunogénicas, razón por la cual han sido ampliamente estudiadas como posibles elementos de diagnóstico de infecciones causadas por dichos organismos. No obstante, su rol como lipoproteínas participantes del metabolismo lipídico de los cestodos o su posible función en la relación parásito-hospedador ha sido menos explorado.

En el caso particular de EgAgB, esta lipoproteína fue encontrada en el líquido hidático de E. granulosus (siendo uno de los componentes mayoritarios de dicho líquido), aunque está presente también en protoescólices y capa germinativa. EgAgB es uno de los antígenos que se usan hoy en día para el diagnóstico serológico de la hidatidosis. El hecho de que genere respuesta inmune en el hospedador hace pensar que esta lipoproteína podría salir del quiste y estar en contacto con tejidos del hospedador. No obstante, aún no hay evidencia clara de que esto sea así (Silva-Álvarez et al., 2015a).

Tal como se mencionó, EgAgB es una lipoproteína, y como tal, está compuesta por varias subunidades proteicas y por una amplia variedad de lípidos. El componente proteico del EgAgB consiste en varias subunidades codificadas por una familia de genes altamente polimórficos. Esta familia incluye al menos cinco grupos de genes denominados EgAgB1EgAgB5. El número de genes codificantes para las subunidades del EgAgB ha sido motivo de debate, pero en base a los datos obtenidos a partir del análisis genómico de E. granulosus se ha propuesto la existencia de 7 genes, 3 de los cuales serían copias, con pequeñas diferencias entre sí, de EgAgB3. Datos similares se han obtenido a partir del genoma de E. multilocularis (Tsai et al., 2013). Todos los genes poseen estructuras similares con dos exones, el primero de los cuales codifica para un péptido señal de secreción, mientras que el segundo codifica la subunidad madura de 8kDa, tradicionalmente denominadas EgAgB8/1-EgAgB8/5. Cuando se comparan las secuencias aminoacídicas de las subunidades de $\mathrm{EgAgB}$, se encuentra que los miembros de EgAgB1, EgAgB3 y EgAgB5 se parecen más entre sí que a los miembros de EgAgB2 y EgAgB4, y viceversa (Silva-Álvarez et al., 2015a, 2015b). Tal como se ha mencionado, la estructura secundaria de las subunidades de EgAgB es predominantemente a-helicoidal. Mediante modelado molecular se ha encontrado que la distribución de residuos hidrofóbicos e hidrofílicos generaría sitios de unión a ligandos hidrofóbicos. Asimismo, la distribución de cargas sería compatible con la agregación de las subunidades (Silva-Álvarez et al., 2015a).

El componente lipídico de EgAgB ha sido bastante menos estudiado que la parte proteica de dicha lipoproteína. Inicialmente, los estudios se habían enfocado en tratar de determinar, 
principalmente mediante el empleo de sondas fluorescentes, qué clase de lípidos eran capaces de unir las subunidades de EgAgB. De esta manera, se encontró que los ácidos grasos eran candidatos a ser unidos por las apolipoproteínas que componían el EgAgB. No obstante, estudios posteriores en donde se analizaron los lípidos extraídos de las partículas de EgAgB purificado a partir de líquido hidático demostraron que la mezcla de ligandos de la lipoproteína era mucho más compleja. Esos análisis permitieron determinar que dentro de la fracción lipídica del EgAgB podían encontrarse tanto lípidos muy poco polares, como triglicéridos y ésteres de colesterol, como una amplia variedad de fosfolípidos, siendo la fosfatidilcolina el más abundante. Asimismo, el análisis de los ácidos grasos que forman parte de los lípidos complejos demostró que los ácidos palmítico, esteárico y oleico son los más abundantes dentro del EgAgB. En conjunto, los resultados obtenidos hacen pensar en que la disposición de los lípidos y proteínas que componen el EgAgB podría ser similar a la que se encuentra en las lipoproteínas plasmáticas de los vertebrados o de la hemolinfa de invertebrados, es decir, un núcleo hidrofóbico compuesto de triglicéridos y ésteres de colesterol, rodeado de fosfolípidos, colesterol no esterificado y proteínas (Silva-Álvarez et al., 2015a).

Dada la limitadísima capacidad biosintética de Echinococcus y su necesidad de adquirir los lípidos a partir de su hospedador, es sumamente lógico pensar que de allí provienen los componentes lipídicos del EgAgB. Esto apoya las hipótesis que plantean que el EgAgB estaría relacionado con la adquisición de nutrientes. Lo que se desconoce es cuáles serían los mecanismos mediantes los cuales el EgAgB adquiere dichos lípidos, no obstante, algunas posibilidades han sido planteadas. Una posibilidad es que el EgAgB pueda interactuar con las lipoproteínas plasmáticas del hospedador y así cargarse de lípidos, de manera análoga a lo que ocurre entre diferentes lipoproteínas plasmáticas de vertebrados. Esto podría ocurrir alrededor de los tejidos del hospedador, o bien dentro del líquido hidático, ya que se ha encontrado apolipoproteína A-I formando parte de dicho líquido, señalando que las HDL (lipoproteínas de alta densidad) del hospedador podrían estar ingresando al quiste por algún mecanismo que aún se desconoce. Otra posibilidad es que el EgAgB adquiera lípidos a partir de las células del hospedador. En este sentido, se ha demostrado que EgAgB es capaz de unirse in vitro a monocitos, macrófagos, células dendríticas y neutrófilos, aunque todavía no se conoce que receptores estarían involucrados ni que destinos tendría el EgAgB en esos casos. Por otra parte, en cualquier caso, el EgAgB tendría que interactuar con receptores en células del parásito para poder entregar los lípidos adquiridos a los tejidos del cestodo. En ese sentido, se ha visto en los genomas de E. granulosus y $E$. multilocularis que flanqueando a los genes de EgAgB se encuentran genes que codificarían para proteínas con dominios homólogos a los receptores de LDL (lipoproteínas de baja densidad). Dado este panorama, la primera opción parecería más viable, es decir, la interacción entre lipoproteínas del 
hospedador y el parásito dentro del quiste y la posterior distribución de los lípidos por parte del EgAgB hacia diversos tejidos del parásito por interacción con receptores del mismo (SilvaÁlvarez et al., 2015a). No obstante, cabe mencionar que ensayos in vitro realizados con TsHLBP de Taenia solium han demostrado que esa lipoproteína tendría capacidad de unir ácidos grasos y transportarlos a través de la pared de la larva (Lee et al., 2007).

Sumado a su posible rol en la adquisición y distribución de lípidos, existen evidencias que atribuyen al EgAgB un rol de modulador en la respuesta inmune del hospedador. Por ejemplo, se ha visto que el EgAgB purificado a partir de líquido hidático inhibiría, in vitro, la quimiotaxis de monocitos (Silva-Álvarez et al., 2015a). Otros estudios han atribuido al EgAgB la capacidad de interferir en la diferenciación y activación de células dendríticas, las cuales son claves tanto para el desarrollo de reacciones inflamatorias locales en respuesta a una señal de peligro como para la activación de linfocitos T específicos (Rigano et al., 2007).

\subsection{Proteínas que unen ácidos grasos (FABPs)}

En primer lugar, se describirán brevemente las características de las FABPs de mamíferos, que han sido las primeras en ser descubiertas y por ende las más estudiadas. Posteriormente, se analizarán los datos disponibles sobre las FABPs de invertebrados, en particular de platelmintos parásitos.

Las FABPs son un conjunto de proteínas citosólicas de alrededor de 15kDa expresadas en la mayoría de las células de los mamíferos, en muchas de ellas a niveles muy altos, sobre todo en aquellas que poseen un metabolismo de ácidos grasos muy importante, como los hepatocitos, enterocitos, adipocitos y miocitos. La familia de las FABPs de mamíferos incluye a 9 FABPs y a las proteínas celulares que unen retinoides, aunque recientemente se ha descubierto una décima FABP (Smathers \& Petersen, 2011; Storch \& Córsico, 2008).

Históricamente, las FABPs han sido designadas de acuerdo al tejido en el que fueron descubiertas, aunque luego se encontró que podían expresarse en diferentes tejidos, y que una misma célula podía expresar más de una FABP. No obstante esto, y a pesar de que se ha buscado instalar una nomenclatura empleando números para designar a los genes de las FABP, los nombres más tradicionales siguen siendo los más usados. En la Tabla I-2 se detalla la nomenclatura y distribución tisular de dichas proteínas.

Todos los genes de las FABPs humanas poseen una organización similar que consiste en cuatro exones y tres intrones, cuyas posiciones también se conservan. El largo de los intrones, sin embargo, es muy variable. El intrón 1 por ejemplo, posee 3,4; 2,3 y 1,2kb en los genes fabp3, fabp8 y fabp2, respectivamente. Los exones, por su parte, normalmente codifican secuencias de aminoácidos relativamente cortas: 23-24 aminoácidos en el exón 1, 57-58 en el 2, 34-36 en el 3, y 16-17 en el 4. La estructura general de los genes se conserva también 
en otros miembros de la familia de las FABPs, como las proteínas celulares que unen ácido retinoico (CRABPs) y las proteínas celulares que unen retinol (CRBPs), aunque en esos casos la longitud promedio de los intrones resulta ser significativamente mayor (Smathers \& Petersen, 2011; Storch \& Córsico, 2008). Asimismo, se han identificado en los genes de las FABPs secuencias consenso de inicio de la transcripción (caja TATA) así como elementos potenciadores (o enhancers) que dirigen la expresión de las FABPs en los diversos tejidos. Se ha determinado también que la expresión de algunas FABPs se encuentra regulada por sus propios ligandos. Por otra parte, cabe destacar que algunos genes de la familia se encuentran agrupados en determinadas regiones del genoma. Este es el caso para los genes fabp4, fabp5, fabp8 y fabp9, los cuales se ubican en el locus 8q21. El gen fabp12, del cual no se posee tanta información, pero ya ha sido clonado, corresponde también a esta región. Se han identificado también algunos pseudogenes para fabp3 y fabp5 (Smathers \& Petersen, 2011).

Desde el punto de vista proteico, tal como se dijo antes, las FABPs son proteínas relativamente pequeñas, con alrededor de 130 aminoácidos, cuyas estructuras primarias presentan un nivel de similitud moderado (entre 20 y $70 \%$ ). Por otra parte, la estructura terciaria de las proteínas de esta familia sí se encuentra altamente conservada. Se caracteriza por la presencia de 10 hebras $\beta$ antiparalelas que, agrupadas en dos hojas $\beta$ de 5 hebras cada una y dispuestas de forma prácticamente ortogonal, forman un barril $\beta$. Este barril se encuentra coronado, en uno de sus lados, por dos pequeñas hélices a que forman parte de lo que se denomina región portal (Ver Figura 1-10). Dichas hélices se ubican entre las dos primeras hebras $\beta$ del barril y están separadas entre sí por un giro. El motivo hélice-giro-hélice posee interacciones de largo alcance con el giro entre las hebras $\beta C$ y $\beta D\left(3^{\circ}\right.$ y $4^{\circ}$, respectivamente) y sería lo que determina el ingreso y egreso del ligando, de allí la denominación de región portal que se mencionó previamente (Furuhashi \& Hotamisligil, 2008; Smathers \& Petersen, 2011; Storch \& Córsico, 2008; Storch \& McDermott, 2009). Por otra parte, las FABPs comparten también ciertas secuencias de tipo "huella digital", o fingerprints, compuesta por tres elementos, o motivos, denominados FATTYACIDBP1-3 (patrón PRINTS FATTYACIDBP; PR00178) (Furuhashi \& Hotamisligil, 2008; Smathers \& Petersen, 2011). EI motivo 1 incluye un triplete G-x-W (donde $x$ puede ser cualquier aminoácido) que forma parte de la primera hoja $\beta(\beta A)$ de la estructura del barril. Este primer motivo es muy similar al que se encuentra en la familia de las lipocalinas, las cuales son parte, junto a las FABPs y las avidinas, de la superfamilia de las calicinas (Flower, 1996). El motivo 2 abarca el extremo C terminal de la cuarta hebra $(\beta D)$ e incluye la quinta hebra $(\beta E)$. Finalmente, el motivo 3 codifica las hebras 9 y 10, es decir, $\beta$ I y $\beta J$ (Furuhashi \& Hotamisligil, 2008; Smathers \& Petersen, 2011). 
La cavidad del barril $\beta$ es unas dos a tres veces mayor al volumen de los ácidos grasos que se unen a las proteínas y posee en su interior moléculas de agua ordenadas, unidas por puente hidrógeno a residuos polares (Storch \& Córsico, 2008). Dichas moléculas de agua, junto con residuos no polares del interior del barril, dirigen la posición de las colas hidrocarbonadas de los ácidos grasos. Los extremos carboxilato, por su parte, suelen interactuar con residuos de arginina u otros aminoácidos polares (Furuhashi \& Hotamisligil, 2008; Storch \& McDermott, 2009).

\begin{tabular}{|c|c|c|}
\hline Gen & Nombre común & Localización en humanos \\
\hline fabp1 & L-FABP, FABP hepática & Hígado, intestino delgado, páncreas, pulmón, riñon, estómago \\
\hline fabp2 & I-FABP, FABP intestinal & Intestino delgado, hígado \\
\hline fabp3 & $\begin{array}{l}\text { H-FABP, FABP cardiaca, FABP } \\
\text { muscular }\end{array}$ & $\begin{array}{l}\text { Músculo cardiaco y esquelético, cerebro, riñon, pulmón, estómago, testículo, } \\
\text { glándulas adrenales, glándulas mamarias, placenta, ovario, tejido adiposo } \\
\text { marrón }\end{array}$ \\
\hline fabp4 & A-FABP, FABP de adipocito, aP2 & Adipocitos, macrófagos, células dendríticas, músculo esquelético \\
\hline fabp5 & $\begin{array}{l}\text { E-FABP, K-FABP, FABP epidermal, } \\
\text { FABP de keratinocito }\end{array}$ & $\begin{array}{l}\text { Piel, lengua, adipocitos, macrófagos, células dendríticas, glándulas mamarias, } \\
\text { cerebro, estómago, intestino, riñon, hígado, pulmón, corazón, músculo } \\
\text { esquelético, testículos, retina, bazo, placenta, cristalino }\end{array}$ \\
\hline fabp6 & $\begin{array}{l}\text { II-FABP, FABP ileal, I-BABP } \\
\text { (Proteina intestinal que une ácidos } \\
\text { biliares) }\end{array}$ & İleon, ovarios, glándulas adrenales, estómago \\
\hline fabp7 & B-FABP, FABP cerebral & $\begin{array}{l}\text { Cerebro, sistema nervioso central, células de la glia, retina, glándulas } \\
\text { mamarias }\end{array}$ \\
\hline fabp8 & M-FABP, FABP de mielina, mP2 & Sistema nervioso periférico, células de Schwann \\
\hline fabp9 & T-FABP, FABP de testículo & Testículos, glándulas salivales, glándulas mamarias \\
\hline fabp12 & - & Células de retinoblastoma \\
\hline
\end{tabular}

Tabla I-2. Nomenclatura y localización de las FABPs de humanos. La tabla muestra la denominación de los genes que codifican para las diferentes FABPs de humanos, así como los nombres más comunes con los que se conoce a estas proteínas. Se detallan también los tejidos/células en los que se ha encontrado expresión de estas proteínas. La información de esta tabla ha sido adaptada a partir de (Furuhashi \& Hotamisligil, 2008; Smathers \& Petersen, 2011; Storch \& Córsico, 2008)

Un aspecto interesante vinculado a la región portal de las FABPs se deriva de los experimentos in vitro de transferencias de ácidos grasos fluorescentes a membranas fosfolipídicas artificiales. A partir de dichos experimentos, se ha dividido a las FABPs en dos grupos de acuerdo a los mecanismos empleados por las mismas para transferir los ácidos grasos a membranas fosfolipídicas. Por un lado se encuentran las FABPs que emplean un mecanismo de tipo "colisional" en el que el paso limitante de la velocidad está dado por la 
interacción directa de la proteína con las membranas, y por otra parte se encuentran las que emplean un mecanismo de tipo "difusional" en donde el paso limitante implica la disociación del ácido graso de la proteína. La mayoría de las FABPs, incluyendo I-FABP, A-FABP, HFABP, M-FABP y E-FABP, pertenecen al primer grupo, mientras que sólo L-FABP y la proteína

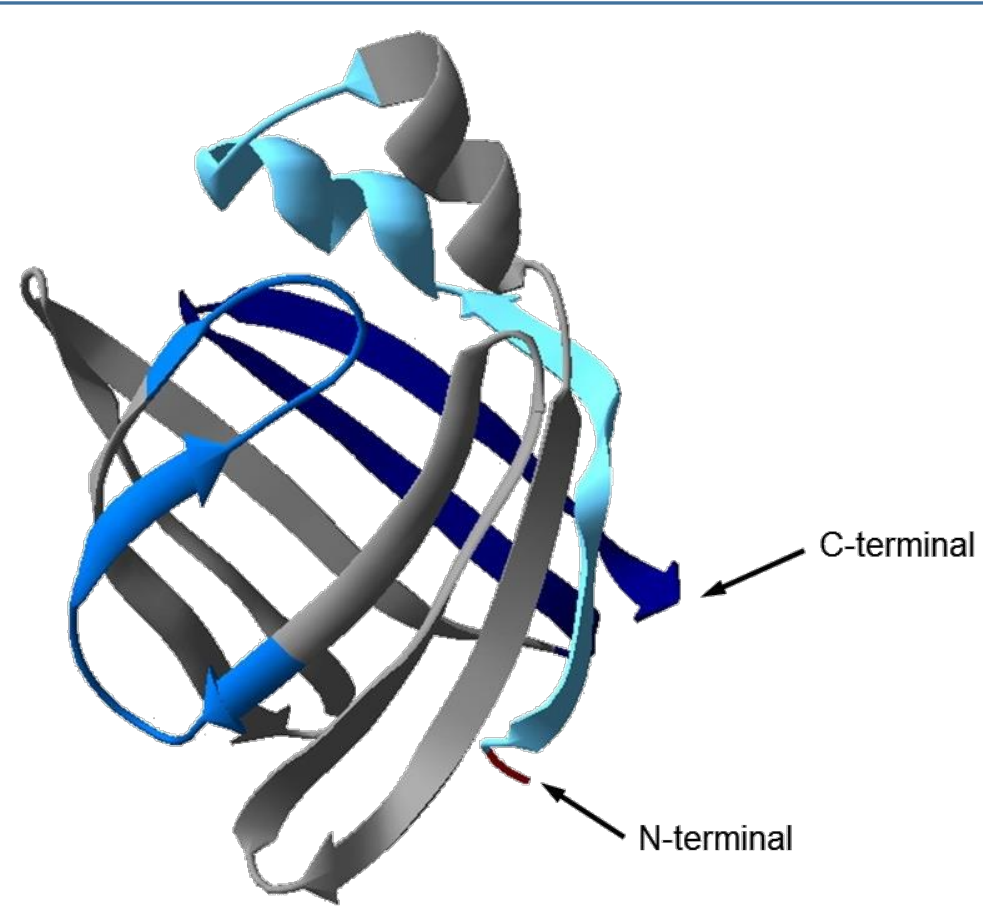

Figura I-10. Estructura terciaria de las FABPs. En la figura se muestra, como esquema de cintas, la estructura terciaria de la FABP intestinal (I-FABP) humana (PDB: $1 \mathrm{KZW}$ ). Se observa claramente la estructura de barril $\beta$ coronado por dos $\alpha$-hélices que caracteriza a las FABPs. Las hojas $\beta$ se denominan $\beta A-\beta J$, comenzando desde el extremo $\mathrm{N}$-terminal, mientras que las hélices se denominan al y all, en el mismo sentido. En distintas tonalidades de azul, de más claro a más oscuro, se destacan los tres motivos que constituyen la huella digital de la familia de las FABPs. Para el caso de I-FABP, los mismos abarcan los aminoácidos 2-24 (motivo 1), 61-77 (motivo 2) y 110-130 (motivo 3), según lo determinado mediante el software de análisis de secuencias proteicas InterPro (http://www.ebi.ac.uk/interpro/).

celular de unión a retinol II pertenecen al grupo de las FABPs "difusionales". El análisis de los factores estructurales que definen estos comportamientos determinó que la región portal y en particular el motivo hélice-giro-hélice eran en gran parte responsables de las diferencias encontradas entre los dos grupos de FABPs. La interacción proteína-membrana necesaria para la transferencia de ligandos en las FABPs "colisionales" estaría conducida principalmente por el potencial electrostático positivo de la región portal de estas proteínas y por el carácter anfipático de la hélice al (Storch \& Córsico, 2008; Storch \& McDermott, 2009).

Estudios estructurales, por otra parte, han revelado que las formas libres de ligandos de las FABPs (formas apo-FABP) y aquellas que poseen ligandos (holo-FABP) difieren en ciertos 
aspectos de su conformación. Se ha visto que en las formas apo, tanto el giro entre las hebras $\beta C$ y $\beta D$ como ciertas regiones de la hélice all poseen mayor movilidad que en las formas holo, lo que hace pensar en que pueden existir cambios conformacionales en la región portal vinculados al ingreso o egreso de ligandos, los cuales pueden ser inducidos por la interacción de las FABPs con membranas u otras proteínas. De este modo, la interacción de las FABPs colisionales con membranas desplazaría los equilibrios hacia conformaciones en donde se facilite la liberación o captación del ligando, mientras que en el citoplasma se favorecerían más las estructuras conteniendo el ligando, de modo que las FABPs puedan actuar como transportadores citoplasmáticos de ligandos hidrofóbicos (Hodsdon \& Cistola, 1997; Storch \& Córsico, 2008; Storch \& McDermott, 2009). Por otra parte, en A-FABP, se ha visto que por unión a determinados ligandos se estabilizan ciertas conformaciones que favorecen la exposición, en las regiones correspondientes a las hélices $\alpha$, de aminoácidos básicos que constituyen una señal de localización nuclear no evidente en la secuencia de aminoácidos de la proteína. Se ha postulado que la activación de dicha señal por acción de algunos ligandos específicos estaría relacionada con la capacidad de A-FABP de transportar al núcleo ligandos de los receptores activados por proliferador de peroxisoma, o PPAR según sus siglas en inglés (Gillilan et al., 2007).

En cuanto a la capacidad de unión a ligandos, la mayoría de las FABPs son capaces de unir un único ácido graso en su interior, orientando el extremo carboxilo hacia el interior del barril. No obstante, L-FABP se destaca por tener la capacidad de unir dos ácidos grasos al mismo tiempo, uno de los cuales ubica su carboxilato hacia adentro del barril, mientras que el carboxilato del otro ácido graso queda cerca de la superficie de la proteína, expuesto al solvente. Asimismo, L-FABP tiene la capacidad de unir una variedad más o menos amplia de ligandos como lisofosfolípidos, grupo hemo y derivados de ácidos grasos unidos a coenzima A (acil-CoA). II-FABP, por su parte, une principalmente ácidos biliares, aunque posee capacidad de unir ácidos grasos con menor afinidad (Smathers \& Petersen, 2011; Storch \& Córsico, 2008).

Cabe destacar que a pesar de la vasta información disponible en relación a la estructura, la capacidad de unión a ligandos, la caracterización de los mecanismos de transferencia de los mismos y la localización tisular de las FABPs, la función específica de estas proteínas y los mecanismos por los cuales ejercen dichas funciones aún no se encuentran del todo aclarados. No obstante, se han podido asignar algunos roles a algunas de las FABPs a partir de experimentos con células y animales knocked out para sus genes. De ese modo, se ha propuesto, por ejemplo, que L-FABP estaría involucrada en el transporte intracelular de ácidos grasos y otros ligandos hidrofóbicos, como puede ser el transporte de ligandos de PPAR al núcleo. Se ha propuesto también que tendría algún rol en la proliferación celular y el direccionamiento de los ácidos grasos a diferentes vías metabólicas. Por otra parte, L-FABP 
intervendría en la producción hepática de lipoproteínas de muy baja densidad (VLDL), mientras que en intestino sería esencial para la formación de los quilomicrones. Asimismo, se ha sugerido que A-FABP tendría un papel importante en el almacenamiento y liberación de triglicéridos en adipocitos, en la regulación de la producción de citoquinas en macrófagos, y en la regulación de la acción de factores de transcripción, mediante su ingreso al núcleo y transporte de ligandos a dicho compartimiento celular. Para H-FABP se han propuesto roles en la regulación de la incorporación y oxidación de ácidos grasos en corazón y músculo esquelético, así como funciones relacionadas al control de la proliferación celular (Storch \& Córsico, 2008).

Como se puede apreciar por lo anteriormente descripto, es mucho lo que aún resta comprender sobre la función de las proteínas de la familia de las FABPs, tanto a nivel general, como para cada una de ellas.

\subsubsection{FABPs en invertebrados}

El estudio de las FABPs de invertebrados comenzó en 1990 (unos 20 años después de haberse descripto la primera FABP), cuando se describió una FABP en Schistocerca gregaria, o langosta del desierto (Haunerland and Chisholm, 1990). A partir de allí, se han descripto varias FABPs de organismos tales como nematodos (parásitos y de vida libre), moluscos, insectos y platelmintos.

Dentro de las FABPs de platelmintos, la primera en ser descripta fue la proteína Sm14 del parásito Schistosoma mansoni (Moser et al., 1991). Luego se aislaron análogos de $S$. japonicum (SjFABPc), Fasciola hepatica (Fh15) y F. gigantica (FgFABP) (Becker et al., 1994; Estuningsih et al., 1997; Rodríguez-Pérez et al., 1992). En todos esos casos, lo más llamativo de estas proteínas era que resultaban ser inmunogénicas, y que extractos en los que ellas estaban presentes generaban protección frente a infecciones experimentales. Asimismo, el hecho de que los platelmintos no puedan sintetizar la mayoría de sus lípidos de novo, contribuyó a que el estudio de las FABPs en estos organismos fuera creciendo con el tiempo. Fue en esos años también cuando se detectó la primera FABP de E. granulosus, EgFABP1 (Esteves et al., 1993). Los detalles sobre las FABPs de E. granulosus se darán más adelante, en esta sección.

Tal como ocurre con las FABPs de mamíferos, las FABPs de invertebrados guardan un porcentaje de identidad de secuencia muy variable. Al compararlas con las FABPs de vertebrados se encontró que la mayor similitud se daba con las de corazón o H-FABP, aunque los porcentajes de similitud con las FABPs de vertebrados en general son bajos. No obstante la baja homología de secuencia, la estructura terciaria se conserva, tal como ocurre con las demás FABPs. Cabe destacar que se observa mayor conservación de algunos aminoácidos 
en los giros entre hebras $\beta$ del barril, en la hélice al y en el final de la all, así como de los involucrados en la unión del carboxilato de los ácidos grasos que actúan como ligandos (Esteves \& Ehrlich, 2006).

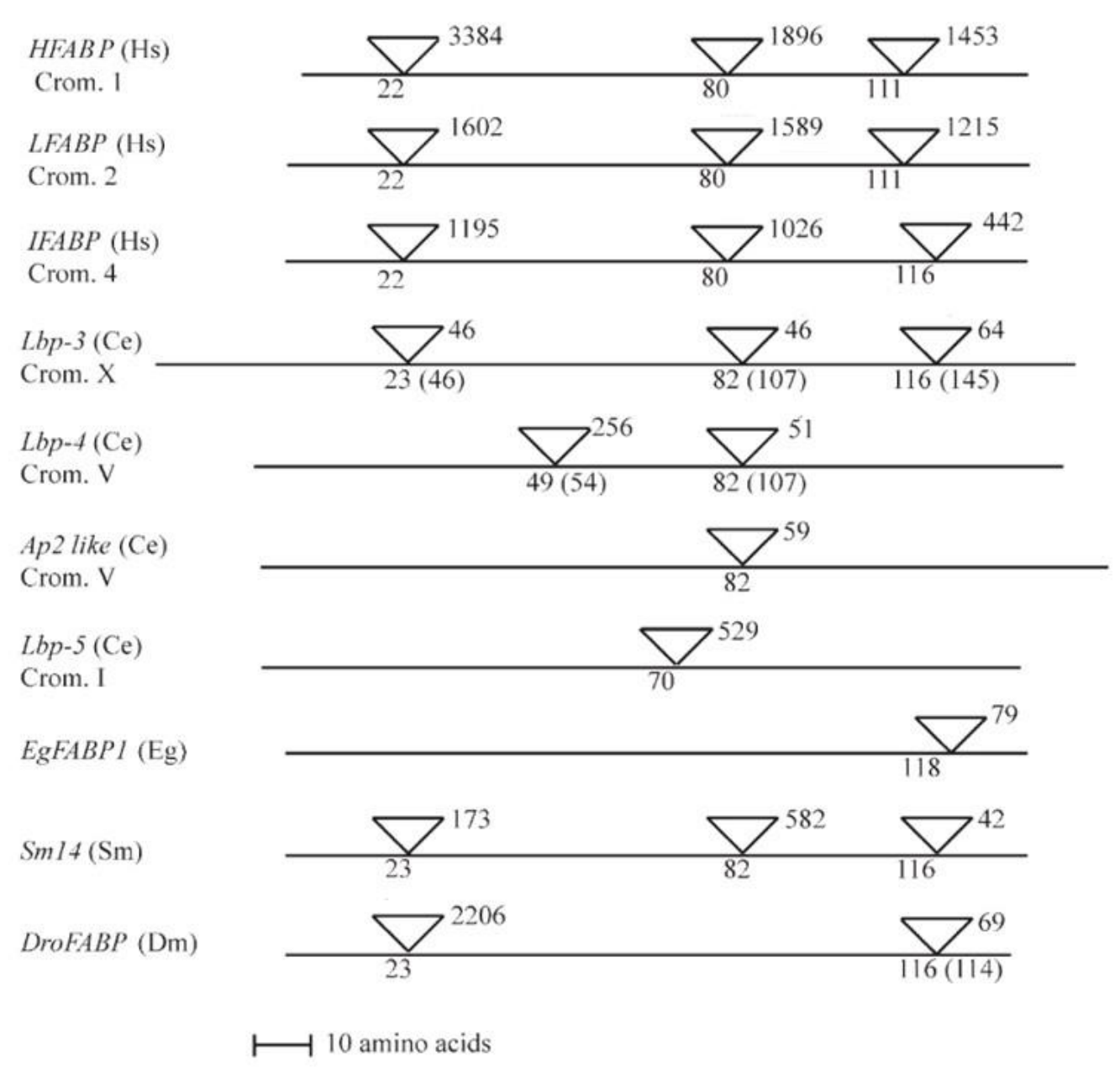

Figura l-11. Posición de intrones en genes de FABPs. Las líneas simbolizan las secuencias proteicas de diferentes FABPs. Los triángulos $(\nabla)$ indican la posición de los intrones. Los números debajo de $\nabla$ indican la posición del codón donde se ubica el intrón, de acuerdo a la numeración de las FABPs de vertebrados. Entre paréntesis se indica la posición verdadera del codón, si la misma difiere respecto a las FABPs de vertebrados. Los números por encima de $\nabla$ indican la longitud del intrón (en pares de bases, pb). Las FABPs simbolizadas en la figura son: $\mathrm{H}$-, L- e I-FABP de humano (Homo sapiens, Hs), LBP-3, LBP-4, LBP-5 y aP2-like de Caenorhabditis elegans (Ce), EgFABP1 de E. granulosus (Eg), Sm14 de Schistosoma mansoni (Sm) y DroFABP de Drosophila melanogaster (Dm). Esta figura ha sido adaptada de (Esteves \& Ehrlich, 2006)

Desde el punto de vista de la estructura génica de las FABPs, cabe destacar que en invertebrados parecen conservarse las posiciones de los intrones descriptos en las FABPs de vertebrados, aunque el número y el tamaño de los mismos son variables (Ver Figura l-11). En FABPs de $C$. elegans se han encontrado intrones en posiciones no conservadas, y se ha visto 
que el número, posición y tamaño de los mismos varía entre las diferentes FABPs de dicho organismo (Esteves \& Ehrlich, 2006; Plenefisch et al., 2000). Es importante tener en cuenta, no obstante, que algunas de las FABPs de $C$. elegans corresponden a un grupo de FABPs específicas de nematodos, denominadas nemFABPs, que se caracterizan por poseer secuencias señales de secreción y ciertas variaciones estructurales, principalmente en ciertos giros del barril (Esteves \& Ehrlich, 2006; Franchini et al., 2015; Plenefisch et al., 2000).

\subsubsection{FABPs en Echinococcus spp.}

La primera FABP descubierta en E. granulosus fue EgFABP1. Esta proteína se identificó a partir de una biblioteca de expresión de cDNAs (ADN complementario al ARN mensajero) obtenidos a partir de protoescólices de E. granulosus. La biblioteca fue analizada utilizando sueros generados contra extractos de protoescólices y capa germinativa ( $\alpha-P E$ y $\alpha-C G$, respectivamente). Se aislaron clones que reaccionaran específicamente con el suero $\alpha-P E$ y no con $\alpha-C G$, con el objetivo de identificar genes que se expresaran diferencialmente en distintos estadios del parásito (Esteves et al., 1993).

Al secuenciar el clon obtenido, se encontró un marco de lectura abierto correspondiente a 133 aminoácidos, con homología de secuencia a las proteínas de la familia de las FABPs. Inicialmente se denominó a dicha proteína EgDf1 (E. granulosus differential factor 1, es decir, factor diferencial 1 de E. granulosus) por la manera en la que fue identificada, pero luego fue renombrada EgFABP1, reflejando así su naturaleza de FABP. Por análisis de Western Blot, se identificó a la proteína solo en extractos de protoescólices, y no en capa germinativa. Ensayos de inmunolocalización determinaron que la expresión de EgFABP1 se encontraba más localizada en el tegumento de los protoescólices (Esteves et al., 1993).

Posteriormente, se llevó a cabo la expresión recombinante y purificación de EgFABP1 en Escherichia coli, y se analizó su capacidad de unión a ligandos. Dicho análisis se llevó a cabo empleando los ácidos grasos fluorescentes ácido cis-parinárico y ácido trans-parinárico. En primer lugar se estudió la capacidad de EgFABP1 de unir sendos ácidos grasos, y luego se probó la capacidad de otros ligandos de desplazarlos del sitio de unión de la proteína. Los ensayos de desplazamiento, que emplearon numerosos ligandos para el análisis, indicaron la preferencia de EgFABP1 por ácidos grasos de cadena larga, principalmente insaturados. Los ácidos grasos que mayor desplazamiento produjeron fueron los ácidos araquidónico, oleico, linoleico, linolénico, palmítico (saturado), palmitoleico y esteárico (saturado). Estos ensayos sugirieron también la existencia de más de un sitio de unión para los ácidos grasos en esta FABP (Alvite et al., 2001).

La estructura cristalográfica de EgFABP1 ha sido resuelta (Ver Figura l-12), y confirmó la estructura de barril $\beta$ formado por 10 hebras antiparalelas, coronado por dos hélices $\alpha$, típica 
de las FABPs (Jakobsson et al., 2003). De este modo, se confirmó lo que había sido propuesto por modelado molecular, aunque con algunas variaciones (Paulino et al., 1998). La comparación de la estructura de EgFABP1 con las estructuras de otras FABPs de las que se disponía en ese momento confirmó que la misma se parecía más al grupo de H-FABP, que incluye, entre otros a mP2, A-FABP, B-FABP y E-FABP (Jakobsson et al., 2003).

Los estudios estructurales revelaron la existencia de una molécula de ácido graso unido a la proteína, a pesar de que la misma había sido sometida a un proceso de deslipidización mediante tratamiento, en batch, con una resina hidrofóbica. La densidad electrónica encontrada se interpretó como perteneciente al ácido palmítico. La disposición del ligando en el sitio de unión de EgFABP1 reveló que el ácido graso se encuentra plegado, en forma de $\mathrm{U}$, disponiéndose prácticamente en un único plano. El extremo carboxilato del ácido graso interactúa con la proteína a través de una tríada Arg...Arg-X-Tyr, que forman el motivo $P 2$, presente también en mP2, A-FABP y otras FABPs del mismo grupo. La primera Arg de dicho motivo se encuentra sobre el final de la hebra $\beta \mathrm{H}$, mientras que el fragmento Arg- $x-T y r$ se localiza en la hebra $\beta J$. En EgFABP1, un oxígeno del ácido graso interactúa con el grupo -OH de la $\operatorname{Tyr}^{129}$ y el $\mathrm{N} \varepsilon$ de la $\mathrm{Arg}^{127}$, mientras que el otro interactúa con el $\mathrm{Nn}^{2}$ de la $\operatorname{Arg}^{107}$ y con dos moléculas de agua. Por otra parte, tanto para H-FABP como para A-FABP se ha propuesto que otros aminoácidos serían cruciales para la interacción de estas proteínas con la cola hidrocarbonada del ácido graso. En EgFABP1 esos aminoácidos serían $\mathrm{Phe}^{16}$, $\mathrm{Pro}^{76}$ y $A s p^{77}$. Si bien solo Phe y Asp están conservados respecto a lo propuesto para $\mathrm{H}-$ y A-FABP, el $C \beta$ de $\mathrm{Pro}^{76}$ se encuentra aproximadamente en la misma posición que el $C \beta$ de $\mathrm{Ala}^{76}$ de las otras proteínas, por lo que podría ser igualmente importante para la unión del ligando. El análisis de la estructura de EgFABP1 desestimó la posibilidad de un segundo sitio de unión a ligandos en el interior del barril. Por otra parte, los autores revelaron la presencia de S-hidroxicisteína en la posición Cys ${ }^{63}$. Se desconoce si esto ocurre naturalmente en EgFABP1 o si es un artefacto de la expresión recombinante en E. coli (Jakobsson et al., 2003).

Una segunda FABP, EgFABP2, fue encontrada en $E$. granulosus tras analizar una biblioteca genómica de dicho organismo usando una sonda construida a partir de la secuencia de cDNA de EgFABP1 (Esteves et al., 2003). Tras el clonado del gen y el análisis de su secuencia, se reveló que EgFABP2 tiene un único intrón de $80 \mathrm{pb}$ en la posición correspondiente al tercer intrón descripto en otras FABPs, del mismo modo que EgFABP1, cuyo único intrón es de 79pb (Esteves et al., 2003). En el mismo trabajo se estableció que existen mensajeros para ambas FABPs en los protoescólices de $E$. granulosus. Por otra parte, se pudo determinar que el inicio de la transcripción del gen de EgFABP2 ocurre en una A que se encuentra a 13 bases, río arriba, del codón de inicio de la traducción (ATG). El análisis de la región promotora del gen egfabp2 reveló la existencia de posibles regiones consenso encontradas en otros genes eucariotas tales como la caja TATA y la caja CAAT. Asimismo, 
existirían sitios de respuesta a proliferadores de peroxisomas y otros elementos regulatorios similares encontrados en otros genes de FABPs (Esteves et al., 2003). Tal como ocurre con otras FABPs, las funciones específicas de EgFABP1 y EgFABP2 siguen sin ser elucidadas a pesar de la información que se ha ido obteniendo con el pasar de los años.

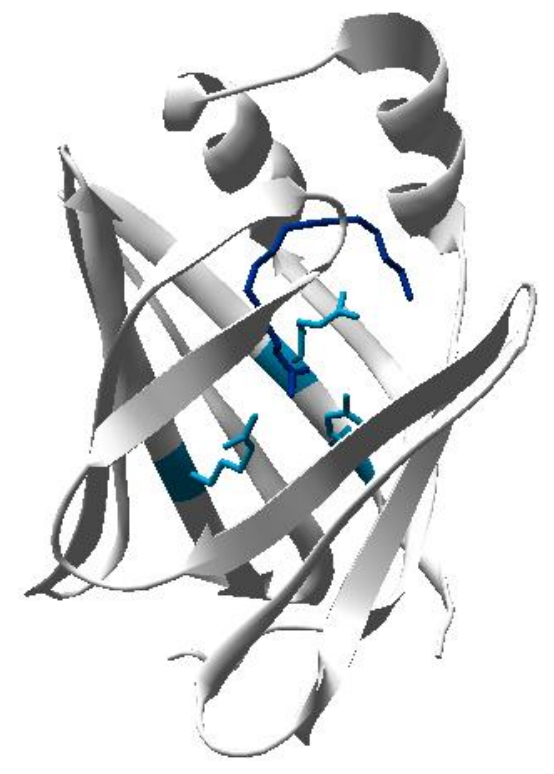

Figura I-12. Estructura terciaria de EgFABP1. En la figura se muestra, como esquema de cintas, la estructura terciaria de EgFABP1 (PDB: 108V). Se observa claramente la estructura de barril $\beta$ coronado por dos $\alpha$-hélices que caracteriza a las FABPs. Con color celeste, se muestran los residuos Arg ${ }^{107}$, $\operatorname{Arg}^{127}$ y Tyr ${ }^{129}$, que forman el motivo P2 de unión al ligando. Con color azul se muestra la molécula de ácido palmítico que se encontró unida a EgFABP1 al determinar su estructura. Se puede observar claramente la disposición en forma de $U$ que adopta dicho ligando.

Recientemente, a partir de la publicación de los genomas de $E$. multilocularis y $E$. granulosus (Tsai et al., 2013; H. Zheng et al., 2013) han surgido publicaciones en donde se propone la existencia de otras FABPs además de EgFABP1 y EgFABP2 en E. granulosus, así como la presencia de sus ortólogos en E. multilocularis (Alvite \& Esteves, 2012; Zheng et al., 2013). Esta información será discutida con mayor detalle a lo largo del presente trabajo. 


\subsection{Hipótesis y objetivos}

\subsubsection{Hipótesis general}

Tal como se comentó previamente, las FABPs son una familia de proteínas ampliamente distribuidas en el Reino Animalia, capaces de unir ácidos grasos y algunos otros ligandos hidrofóbicos, cuyas funciones específicas están lejos de ser comprendidas en su totalidad. Tradicionalmente se ha atribuido a estas proteínas funciones de transporte de ácidos grasos en el citoplasma celular. Se ha sugerido que al unir ácidos grasos de cadena larga, las FABPs no sólo aumentarían la disponibilidad de ácidos grasos solubles para diferentes usos dentro de la célula, sino que la protegerían de los efectos tensioactivos que dichos compuestos tienen, en especial cuando se encuentran en concentraciones algo elevadas. Con el pasar de los años y la acumulación de datos relativos a las FABPs, las mismas pasaron a considerarse partícipes más activos en lo relativo al metabolismo lipídico celular, asignándoseles roles en la regulación de la expresión de genes relacionados a dicho metabolismo, en la regulación de la captación y utilización por parte de las células de ácidos grasos y otros nutrientes, y hasta en procesos de señalización a niveles sistémicos, actuando como adipoquinas (Kralisch \& Fasshauer, 2012; Kralisch et al., 2014).

En el caso de organismos parásitos como Echinococcus spp. que, según la información disponible, tienen una capacidad biosintética limitada y no utilizan los lípidos como fuente de energía, el estudio de las FABPs se torna quizás más importante desde el punto de vista de la comprensión de la biología de estos organismos.

En Echinococcus spp., las FABPs podrían dirigir los ácidos grasos a las vías de síntesis de fosfolípidos de membrana, necesarios para mantener el crecimiento continuo del parásito en su estadio de metacestodo; podrían dirigir ácidos grasos a vías de síntesis de moléculas de señalización como eicosanoides y prostaglandinas, que permitan modular la respuesta inmune del hospedador; e incluso podrían transportar ligandos que tengan un papel importante en la regulación de la increíble plasticidad fenotípica que tienen estos organismos. En este sentido, cabe destacar que existe evidencia de localización nuclear de EgFABP1 (Dra. Adriana Esteves, comunicación personal).

\subsubsection{Objetivo general}

La hipótesis general planteada es claramente un problema muy complejo de resolver, máxime teniendo en cuenta que la bioquímica de Echinococcus spp., y en particular el metabolismo lipídico, es un campo aún muy poco explorado. Es por esto, que en el presente 
trabajo nos hemos propuesto profundizar en los conocimientos relacionados a EgFABP1, en particular en lo referido a su interacción con ligandos y con membranas fosfolipídicas. Si bien esta información no es suficiente para evaluar una hipótesis tan compleja como la propuesta, se espera que sirva para encausar futuras investigaciones al respecto, de modo similar a lo que ha ocurrido con otras FABPs. Asimismo, nos hemos propuesto ampliar el panorama en lo que respecta a la familia de las FABPs en Echinococcus spp., a partir del análisis de los recientemente obtenidos genomas de E. granulosus y E. multilocularis.

\subsubsection{Objetivos específicos}

\subsubsection{Subclonado y purificación de EgFABP1}

El primer objetivo planteado para el presente trabajo fue el subclonado del cDNA de EgFABP1 a un plásmido con un mejor control de la expresión de la proteína recombinante. Asimismo, debieron ajustarse algunos parámetros del proceso de deslipidización de la proteína para que la misma estuviera en condiciones de ser usada para posteriores ensayos biofísicos. La proteína recombinante obtenida fue analizada por dicroísmo circular para chequear que su plegamiento fuera el adecuado.

\subsubsection{Análisis de la interacción de EgFABP1 con ligandos}

Con el objetivo de analizar la interacción de EgFABP1 con ligandos se llevaron a cabo varios ensayos. Por un lado, se extrajeron los lípidos unidos a la proteína recombinante purificada a partir de $E$. coli y se caracterizaron por cromatografía en capa fina y cromatografía gas-líquido. Otro enfoque, consistió en evaluar la interacción de EgFABP1 con ácidos grasos empleando un ensayo de proteólisis parcial que permite distinguir si la proteína se encuentra en un estado más o menos flexible. De esta manera se puede evaluar si la unión a diferentes ligandos estabiliza una misma conformación de la proteína o no. Un análisis similar se realizó empleando la técnica de dicroísmo circular. Finalmente, se evaluó también la interacción de EgFABP1 con derivados fluorescentes de ácidos grasos, de utilidad para los ensayos sucesivos.

\subsubsection{Análisis de la interacción de EgFABP1 con membranas}

El análisis de la interacción de EgFABP1 se llevó a cabo empleando un ensayo de transferencia de ligandos fluorescentes a membranas fosfolipídicas artificiales basado en el 
principio de transferencia de energía de resonancia de Förster (FRET). Estos ensayos han sido aplicados a otras FABPs y han sido el puntapié inicial para el avance en la comprensión de los roles de muchas de ellas. Se empleó también un ensayo de interacción con membranas por competición con citocromo c.

\subsubsection{Identificación y análisis de FABPs de E. multilocularis}

Para llevar a cabo este objetivo, se realizó una estadía de trabajo en el laboratorio del Dr. Klaus Brehm, en la Universidad de Wurzburgo (Alemania). Allí se hicieron búsquedas bioinformáticas en versiones preliminares del genoma de E. multilocularis, disponibles en dicho laboratorio, tendientes a identificar genes ortólogos a EgFABP1 y EgFABP2. Empleando las técnicas de cultivo de células primarias de E. multilocularis puestas a punto en dicho laboratorio, se buscó disminuir la expresión de dichas FABPs empleando ácidos ribonucleicos de interferencia pequeños (siRNAs, small interference Ribonucleic Acids). A partir de cDNA de células primarias se clonaron las secuencias codificantes de las FABPs de E. multilocularis. 
MATERIALES Y MÉTODOS 


\section{MATERIALES Y MÉTODOS}

\subsection{Subclonado y purificación de EgFABP1}

\subsubsection{Subclonado de EgFABP1}

\subsubsection{Extracción y purificación de ADN plasmídico (miniprep)}

Durante el desarrollo de este trabajo, la extracción del ADN se realizó empleando los kits comerciales QIAprep® Spin Miniprep Kit (Qiagen) o GeneJET Plasmid Miniprep Kit (Fermentas), según las indicaciones de los fabricantes. Brevemente, la técnica consiste en hacer un cultivo overnight (aproximadamente $16 \mathrm{hs}$ ) a $37^{\circ} \mathrm{C}$ y con agitación (250rpm) de las bacterias de interés en un medio apropiado (normalmente, LB o Luria-Bertani: 10g/l Triptona; $10 \mathrm{~g} / \mathrm{l} \mathrm{NaCl} ; 5 \mathrm{~g} / \mathrm{l}$ Extracto de Levadura). Al día siguiente, se cosechan $5 \mathrm{ml}$ de cultivo por centrifugaciones sucesivas de $2 \mathrm{~min}$ a $6800 \mathrm{x}$ g en un tubo tipo eppendorf de $1,5 \mathrm{ml}$. Una vez colectadas las bacterias, debe resuspenderse el pellet obtenido en $250 \mu \mathrm{l}$ del buffer de resuspensión provisto por el kit. A continuación debe aplicarse igual volumen de la solución de lisis, y mezclar el contenido del tubo por inversión unas 4 a 6 veces, hasta que se torne más claro y con aspecto viscoso. Posteriormente, dentro de los $5 \mathrm{~min}$ posteriores al agregado del buffer de lisis, se deben incorporar $350 \mu$ de la solución de neutralización y mezclar nuevamente por inversión unas 6 veces. Luego, se centrifuga a velocidad máxima durante 5 min para precipitar el ADN cromosomal y los restos de bacterias; y se transfiere el sobrenadante a una columna de purificación provista en el kit. Luego de centrifugar $1 \mathrm{~min}$ a velocidad máxima, se descarta el filtrado y se lava la columna agregándole $500 \mu l$ de solución de lavado, seguido de una centrifugación de 30-60seg a velocidad máxima. Se hacen dos lavados y luego de la segunda centrifugación se realiza una centrifugación extra para eliminar cualquier resto de solución de lavado que pudiera quedar retenida en la columna. Para finalizar, se hacen dos eluciones con $30 \mu \mathrm{l}$ de buffer de elución $(10 \mathrm{mM}$ Tris- $\mathrm{HCl}, \mathrm{pH} 8.5$; provisto con el kit) cada una, que se colectan en un tubo nuevo por centrifugación a velocidad máxima. El ADN purificado se conserva a $-20^{\circ} \mathrm{C}$.

\subsubsection{Diseño de los primers específicos para EgFABP1}

Los primers específicos para la secuencia codificante del gen de EgFABP1 resultaron de una modificación de los que se emplearon oportunamente en el laboratorio de la Dra. Esteves (Alvite et al., 2001). A dichos primers se les adicionó un sitio de corte para la enzima de 
restricción $\mathrm{BamHI}$, así como algunos nucleótidos extra con la finalidad de mejorar la eficiencia de las digestiones con enzimas de restricción. El diseño de los primers se llevó a cabo empleando las herramientas bioinformáticas brindadas por el sitio web del SDSC Biology Workbench (http://workbench.sdsc.edu). Las secuencias correspondientes a los primers se muestran en el Apéndice 7.1.1.

\subsubsection{Reacción en cadena de la polimerasa (PCR) para amplificar la secuencia codificante del gen egfabp1}

Para la PCR se utilizó la polimerasa de alta fidelidad Platinum ${ }^{\circledR}$ Pfx DNA polymerase (Invitrogen) según las recomendaciones del fabricante. Brevemente, se utilizaron $5 \mu l$ del buffer de amplificación e igual volumen de la solución potenciadora, provistos con la enzima. Se agregó $\mathrm{MgSO}_{4}$ a una concentración final de 1,5mM y los desoxirribonucleótidos (dATP, dGTP, dCTP y dTTP) a una concentración final de 0,3mM cada uno. Asimismo, se usaron $0,32 \mu \mathrm{M}$ de cada uno de los primers (EgFABP1-Fw y EgFABP1-Rv), 1,25 unidades de la polimerasa y aproximadamente 0,5-1nM del ADN molde (pET-5a-egfabp1, generado en el laboratorio de la Dra. Esteves, Universidad de la República, Uruguay). Todo se llevó a 50 $\mu$ l finales con agua bidestilada estéril. Las condiciones utilizadas para la amplificación del inserto de interés fueron las siguientes: $2 \mathrm{~min}$ de incubación a $94^{\circ} \mathrm{C}$ para activar la polimerasa y desnaturalizar por completo el ADN molde; 35 ciclos de $30 \mathrm{seg}$ a $94^{\circ} \mathrm{C}$ (desnaturalización), 30 seg a $58^{\circ} \mathrm{C}$ (hibridización) y $1 \mathrm{~min}$ a $68^{\circ} \mathrm{C}$ (elongación); y finalmente, $5 \mathrm{~min}$ adicionales a $68^{\circ} \mathrm{C}$.

\subsubsection{Digestión de ADN con enzimas de restricción}

Tanto el producto de PCR como el plásmido pET-11b (Novagen), en el cual se subclonó dicho gen, se digirieron con las enzimas Ndel y BamHI (Promega). El buffer empleado para la reacción fue el Buffer $D$ (provisto con las enzimas). Dado que el porcentaje de actividad de la enzima BamHI en el Buffer $D$ es de entre 50 y $75 \%$, se usó el doble de esta enzima que de Ndel. Las mezclas de reacción se hicieron de la siguiente manera: $2 \mu \mathrm{l}$ de Buffer $D$ 10x; $4 \mu \mathrm{g}$ de seroalbúmina bovina (BSA) acetilada (provista con las enzimas); 6 unidades de Ndel; 12 unidades de BamHI; 100-500ng de ADN; y agua bidestilada estéril hasta completar los $20 \mu$ l. Las muestras se incubaron 3 horas a $37^{\circ} \mathrm{C}$ y luego se conservaron a $-20^{\circ} \mathrm{C}$. 


\subsubsection{Electroforesis de ADN en geles de agarosa}

El análisis de los fragmentos de ADN se realizó empleando geles de $0,75-1,5 \%$ de agarosa (Invitrogen) preparados en buffer TBE (90mM Tris-Borato, 2mM EDTA, pH 8) y conteniendo $S Y B R \circledast$ Safe DNA gel stain (Invitrogen) para visualizar el ADN. Las muestras para la electroforesis se prepararon mezclando las soluciones de ADN con buffer de siembra $6 x$ (40\% Sacarosa, 0,25\% Azul de Bromofenol). La electroforesis se llevó a cabo en buffer TBE, a 100V durante aproximadamente $50 \mathrm{~min}$, dependiendo del avance del frente de corrida. Como marcador de peso molecular se utilizó el 100bp DNA Ladder (Invitrogen) para fragmentos pequeños y productos de PCR; el 1 kb Plus DNA Ladder (Invitrogen) para fragmentos grandes; y los marcadores Low DNA Mass Ladder y High DNA Mass Ladder (Invitrogen) para las cuantificaciones de ADN. Las imágenes fueron colectadas empleando un equipo ImageQuant 350 (GE Healthcare Life Sciences) con iluminación ultravioleta, y analizadas con el software provisto con dicho equipo.

\subsubsection{Purificación de fragmentos de ADN a partir de geles de agarosa}

La purificación de ADN a partir de geles de agarosa se realizó empleando filtros UltrafreeßDA (Millipore). Para ello, se cortaron del gel las bandas de interés bajo iluminación con luz UV (reduciendo al mínimo el tiempo de exposición para evitar la inducción de mutaciones en los fragmentos de $A D N$ ) y luego se picó dicha fracción sobre una superficie lisa y limpia, empleando un bisturí. Se colocó el gel triturado en un filtro de los mencionados previamente, y se centrifugó durante 15 min a velocidad máxima. Luego se agregaron $100 \mu l$ de buffer TE (10mM Tris-Hcl, 1mM EDTA, pH 8), se dejó reposar $10 \mathrm{~min}$, y se centrifugó nuevamente a máxima velocidad durante $10 \mathrm{~min}$. A continuación, se llevó a cabo una precipitación del ADN con etanol. Para ello, luego de estimar el volumen del filtrado, se agregó un $10 \%$ de dicho volumen de una solución $3 \mathrm{M}$ Acetato de Sodio, seguido de dos volúmenes de Etanol frío, y se lo incubó overnight a $-20^{\circ} \mathrm{C}$. Posteriormente, se centrifugó la muestra durante 20 min a máxima velocidad y se descartó el sobrenadante. Se procedió a realizar un lavado empleando $500 \mu l$ de Etanol al 70\%, seguido de una centrifugación de 10 min a velocidad máxima. Se descartó el sobrenadante y se dejó secar la muestra cerca del mechero durante aproximadamente 10 min (hasta eliminar los restos de alcohol). Finalmente, se resuspendió el pellet en $25 \mu \mathrm{l}$ de buffer $10 \mathrm{mM}$ Tris- $\mathrm{HCl}, \mathrm{pH}$; y se conservó la muestra a $-20^{\circ} \mathrm{C}$. 


\subsubsection{Desfosforilación de los extremos 5’}

Con la finalidad de evitar la recircularización del vector digerido, se procedió a desfosforilar sus extremos 5'. Para ello, se empleó la enzima Calf Intestine Alkaline Phosphatase (Promega), o CIAP por sus iniciales en inglés. El procedimiento consistió en incubar el vector digerido con la CIAP a una concentración de 0,01 unidades de enzima/pmol de extremos libres de ADN en el buffer de reacción (provisto con la enzima) durante $15 \mathrm{~min}$ a $37^{\circ} \mathrm{C}$ seguido de 15 min a $56^{\circ} \mathrm{C}$. Posteriormente, se repitió el agregado de enzima y las incubaciones, según recomendación del fabricante. Para frenar la reacción se agregaron 200 $\mu \mathrm{l}$ de CIAP Stop Buffer (10mM Tris-HCl; $1 \mathrm{mM}$ EDTA; $200 \mathrm{mM} \mathrm{NaCl} ; 0,5 \%$ SDS; pH 7,5). A continuación se agregó un volumen de Fenol/Cloroformo, se emulsionó la mezcla, y se centrifugó 5 min a máxima velocidad. Se tomó la fase acuosa y se procedió a realizarle una precipitación con etanol, tal como se describió en el ítem 2.1.1.6.

\subsubsection{Ligación}

La ligación del inserto egfabp1 con el vector pET-11b desfosforilado se llevó a cabo empleando la enzima T4 DNA ligase (Invitrogen) según las recomendaciones del fabricante. La reacción se llevó a cabo en presencia de exceso de inserto. La mezcla de enzima, vector e inserto se incubó overnight a $4^{\circ} \mathrm{C}$ en el buffer provisto por el fabricante. La muestra se congelo a $-20^{\circ} \mathrm{C}$ hasta el momento de su uso.

\subsubsection{Preparación de bacterias competentes}

Para la preparación de bacterias competentes se cultivaron las bacterias $O N$ (del inglés overnight, es decir, durante la noche) a $37^{\circ} \mathrm{C}$ con agitación fuerte, en medio LB. Para las cepas E. coli JM109 y E. coli BL21(DE3) (Novagen) no se utilizó ningún antibiótico durante el cultivo, mientras que para la cepa E. coli XL-1 Blue (gentilmente donadas por la Dra. Casalongué, Universidad Nacional de Mar del Plata) se utilizó Tetraciclina (Sigma Aldrich) a una concentración final de $12,5 \mu \mathrm{g} / \mathrm{ml}$. Al otro día se inocularon $100 \mathrm{ml}$ de medio LB fresco con $5 \mathrm{ml}$ del cultivo bacteriano, y se incubaron a $37^{\circ} \mathrm{C}$ con agitación, hasta que la densidad óptica (DO) a $600 \mathrm{~nm}$ alcance las 0,5 unidades. Una vez alcanzadas las condiciones mencionadas, se incubó el cultivo a $4^{\circ} \mathrm{C}$ durante $10-15 \mathrm{~min}$. Seguidamente, se centrifugó el cultivo a 2000rpm durante $15 \mathrm{~min}$ a $4^{\circ} \mathrm{C}$ y se descartó el sobrenadante. El pellet proveniente de $100 \mathrm{ml}$ de cultivo se resuspendió en un total de $30 \mathrm{ml}$ de Buffer TFB1 (100mM RbCl; $50 \mathrm{mM} \mathrm{MnCl}$; $30 \mathrm{mM}$ Acetato de Potasio; $10 \mathrm{mM} \mathrm{CaCl}_{2} ; 15 \%$ Glicerol; pH 5,8; esterilizado por filtración) y se incubó 
durante 90min en hielo. Pasado dicho tiempo, se centrifugó, en frío, la suspensión de bacterias durante $15 \mathrm{~min}$ a $2000 \mathrm{rpm}$. El sobrenadante fue descartado, y se resuspendió el pellet en $4 \mathrm{ml}$ de Buffer TFB2 (10mM MOPS; $10 \mathrm{mM} \mathrm{RbCl;} 75 \mathrm{mM} \mathrm{CaCl}_{2}$; $15 \%$ Glicerol; pH 8; esterilizado en autoclave). Las bacterias competentes se alicuotaron y se congelaron de inmediato a $-80^{\circ} \mathrm{C}$.

\subsubsection{Transformación de bacterias competentes por shock térmico}

Para las transformaciones se utilizaron $100-200 \mu$ l de bacterias competentes y se les adicionó aproximadamente 50ng de ADN plasmídico en un volumen inferior a 10 $\mu$ l. Se mezcló suavemente con el tip y se incubó la mezcla durante 30min en hielo. Pasado dicho tiempo, se incubaron las células durante $50 \mathrm{seg}$ a $42^{\circ} \mathrm{C}$, para luego regresarlas de inmediato al hielo.

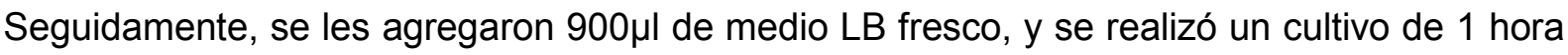
a $37^{\circ} \mathrm{C}$ con agitación. Para llevar a cabo la selección de las bacterias transformadas con el plásmido pET-11b-egfabp1, se realizaron cultivos en placas de LB/Agar/Ampicilina (medio LB conteniendo $15 \mathrm{~g} / \mathrm{l}$ de agar-agar y $100 \mu \mathrm{g} / \mathrm{ml}$ de Ampicilina). Para ello, se sembraron placas con $100 \mu l$ del cultivo y otras con el pellet de bacterias obtenido por centrifugación. Las placas se incubaron unos minutos a temperatura ambiente para que el líquido se absorbiera y, finalmente, invertidas a $37^{\circ} \mathrm{C}$ hasta el día siguiente. Una vez seleccionadas algunas colonias bien aisladas, se cultivaron las mismas en medio LB a $37^{\circ} \mathrm{C}$. Para analizar la presencia del inserto egfabp1 se procedió a realizar PCR con los primers específicos (tal como se describió

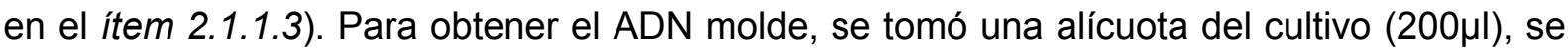
centrifugó $5 \mathrm{~min}$ a velocidad máxima y se resuspendió el pellet en $100 \mu \mathrm{l}$ de agua bidestilada estéril. Las muestras se hirvieron durante $3 \mathrm{~min}$ para producir la lisis de las bacterias, y se utilizaron $5 \mu \mathrm{l}$ de dicha mezcla como molde para la reacción de PCR. De las colonias positivas se extrajo el ADN plasmídico (empleando el método descripto en 2.1.1.1) y se verificó la presencia del inserto por digestión con enzimas de restricción (según lo descripto en 2.1.1.4). Asimismo, las colonias positivas se corroboraron por secuenciación del inserto usando los primers específicos EgFABP1-Fw y EgFABP1-Rv, a través del servicio de Macrogen Inc (Corea del Sur). Para conservar los cultivos bacterianos de interés, se realizaron stocks de glicerol mezclando partes iguales del cultivo y de medio LB conteniendo $20 \%$ de glicerol. Dichos stocks se conservaron a $-80^{\circ} \mathrm{C}$. Para la conservación y amplificación del plásmido se emplearon bacterias de las cepas E. coli XL-1 Blue y E. coli JM109; y para la expresión de la proteína EgFABP1 recombinante se utilizó la cepa E. coli BL21(DE3). 


\subsubsection{Purificación de EgFABP1}

\subsubsection{Screening de expresión de proteínas recombinantes}

Para evaluar los niveles de expresión de EgFABP1 en bacterias E. coli BL21(DE3) se utilizó un protocolo de screening de expresión. Para ello, se realizó un cultivo $\mathrm{ON}$ a $37^{\circ} \mathrm{C}$ de las colonias de interés (previamente chequeadas según lo descripto en el ítem 2.1.1.10) en medio LB con Ampicilina (100 $\mathrm{g} / \mathrm{ml})$. Luego se inocularon $5 \mathrm{ml}$ de medio LB con ampicilina (LB/Amp) fresco con $0,5 \mathrm{ml}$ del cultivo, y se cultivaron las bacterias hasta alcanzar la fase exponencial de crecimiento $\left(\mathrm{DO}_{600}=0,5\right)$. La expresión de la proteína recombinante se indujo empleando una concentración final de $400 \mu \mathrm{M}$ de isopropil- $\beta$-D-tiogalactopiranósido (IPTG, Promega) e incubando el cultivo durante dos horas más en las condiciones ya descriptas. Se incluyó también, como control, un cultivo sin inducir. Los cultivos se cosecharon por centrifugación a 7000rpm durante $5 \mathrm{~min}$ en centrífuga refrigerada Sorvall Legend Mach 1.6R, empleando el rotor TTH-400 Swinging Bucket Rotor (Thermo) con los adaptadores adecuados para tubos tipo Falcon. Los pellets se resuspendieron en $200 \mu$ l de Buffer TEK $(10 \mathrm{mM}$ Tris-HCl; $1 \mathrm{mM}$ EDTA; $100 \mathrm{mM} \mathrm{KCl} ; \mathrm{pH} 7,4)$, y se analizaron por electroforesis desnaturalizante en geles de poliacrilamida, tal como se describirá a continuación.

\subsubsection{Electroforesis desnaturalizante en geles de poliacrilamida (SDS-PAGE)}

La electroforesis de muestras proteicas se llevó a cabo empleando geles de poliacrilamida conteniendo dodecilsulfato de sodio (SDS) en condiciones reductoras, según lo descripto por Laemmli (Laemmli, 1970). Para ello, se prepararon geles separadores de 15\% acrilamida, con zona concentradora de gel de $4 \%$ acrilamida; empleando el equipo MiniProtean Tetracell (BioRad). Los geles empleados fueron de $1 \mathrm{~mm}$ de espesor. Las muestras se prepararon para la electroforesis hirviéndolas durante $5 \mathrm{~min}$ en un buffer de siembra cuya composición fue la siguiente: $70 \mathrm{mM}$ Tris-HCl; $2 \%$ SDS; $10 \%$ Glicerol; 2,5\% $\beta$-mercaptoetanol; $20 \mu \mathrm{g} / \mathrm{ml}$ azul de bromofenol; $\mathrm{pH} 6,8$. La electroforesis se llevó a cabo en dos etapas: inicialmente a $100 \mathrm{~V}$ durante $20 \mathrm{~min}$ y luego a $200 \mathrm{~V}$ durante aproximadamente $50 \mathrm{~min}$ (dependiendo del avance del frente de corrida). El buffer de electroforesis empleado consistió en una solución con 25mM Tris-HCl; 192mM Glicina; 0,1\% SDS; pH 8.3. Como marcador de peso molecular se utilizó el Low Molecular Weight Calibration Kit for SDS (GE Healthcare Life Sciences). La tinción de los geles se llevó a cabo empleando una solución 0,1\% de Coomassie Brilliant Blue R-250 (Bio$\mathrm{Rad}$ ) en $\mathrm{H}_{2} \mathrm{O}$ :Metanol:Ácido acético (5:5:2); y la decoloración, con una solución acuosa con 
$10 \%$ ácido acético y $30 \%$ etanol. Las imágenes se colectaron empleando un transiluminador de luz blanca del equipo ImageQuant 350 (GE Healthcare Life Sciences).

\subsubsection{Expresión y Purificación de EgFABP1}

Para la expresión de la proteína EgFABP1 recombinante se realizó un cultivo $O N$ de bacterias $E$. coli BL21(DE3) portadoras del plásmido pET-11b-egfabp1 en medio LB/Amp. Al día siguiente, se inocularon las bacterias en medio LB/Amp fresco, realizando una dilución 1/50. Las bacterias se cultivaron nuevamente a $37^{\circ} \mathrm{C}$ con agitación, hasta alcanzar la fase de crecimiento exponencial $\left(0,5 \leq \mathrm{DO}_{600} \leq 1\right)$. La expresión de la proteína se indujo con IPTG a una concentración final de $400 \mu \mathrm{M}$ durante 3 horas. Las bacterias se cosecharon por centrifugación a 7000rpm durante $10 \mathrm{~min}$ a $4^{\circ} \mathrm{C}$ en botellas de $250 \mathrm{ml}$, empleando la centrífuga Avanti JE (Beckman Coulter) con el rotor JLA-16.250. El pellet proveniente de 1 litro de cultivo se resuspendió en $10 \mathrm{ml}$ de buffer TEK + 1mM ditiotreitol (DTT). A continuación, las bacterias se lisaron por aplicación de ultrasonido empleando un sonicador de punta S-450 (Branson) con punta chata. Se utilizaron ciclos de trabajo de $50 \%$, con potencia de entre 4 y 6 , por períodos de 30 segundos, seguidos de 30 segundos de incubación de la muestra en hielo. La cantidad de intervalos de sonicación dependió de la clarificación observada en el cultivo. El material lisado se centrifugó a $30000 \mathrm{rpm}$ durante $25 \mathrm{~min}$ a $4^{\circ} \mathrm{C}$ en una ultracentrífuga Optima LE-80K (Beckman Coulter), empleando el rotor 70.1 Ti. El sobrenadante de dicha centrifugación fue sometido a un proceso de salting out por incubación del mismo con medio volumen de $\left(\mathrm{NH}_{4}\right)_{2} \mathrm{SO}_{4}$ saturado durante 2 horas con agitación a $4^{\circ} \mathrm{C}$. A continuación, se centrifugaron las muestras a $4^{\circ} \mathrm{C}$ durante $30 \mathrm{~min}$ a $10000 \mathrm{rpm}$ empleando la centrífuga Avanti JE con el rotor de ángulo fijo JA-25.50. Previo a su paso por la columna de exclusión molecular, se concentró el sobrenadante del salting out empleando un concentrador de presión positiva (Amicon), y se le agregaron aproximadamente $120000 \mathrm{cpm}$ de $\left[1-{ }^{14} \mathrm{C}\right]$-Palmitato. Luego de una incubación de 15min, se sembró la muestra en una columna de exclusión molecular con resina Sephadex G-50 (Pharmacia Biotech Inc.) a un flujo de alrededor de 1,5ml/min utilizando una bomba peristáltica P-1 (Pharmacia Biotech Inc.). Para la cromatografía se utilizó un buffer de fosfatos de $\mathrm{pH} 7,4\left(6 \mathrm{mM} \mathrm{K}_{2} \mathrm{HPO}_{4} ; 4 \mathrm{mM} \mathrm{KH}_{2} \mathrm{PO}_{4} ; 150 \mathrm{mM} \mathrm{KCl}\right)$. El seguimiento de la cromatografía se realizó por medición espectrofotométrica a $280 \mathrm{~nm}$, SDS-PAGE, y medición de la radiactividad empleando un contador de centelleo Wallac 1214 Rackbeta. Los pasos siguientes de la purificación consisten en la realización de una cromatografía de intercambio iónico (para eliminar los ácidos nucleicos contaminantes) y una cromatografía de interacción hidrofóbica (para remover los ligandos lipídicos que puedan estar unidos a la proteína). Para proceder a la deslipidización de la proteína, se colectaron las fracciones que contenían EgFABP1, se concentraron en el concentrador Amicon de presión positiva y luego empleando un 
concentrador Vivaspin (Sartorius). Durante este último procedimiento, se cambió también el buffer de la solución por uno de fosfatos adicionado con $\mathrm{KCl}$, a una concentración final de $1 \mathrm{M}$. Por otro lado, se equilibró la columna de cromatografía de interacción hidrofóbica, termostatizada a $37^{\circ} \mathrm{C}$, en el mismo buffer. La columna empleada fue una $X K$ 16/40 (GE Healthcare Life Sciences) con resina Lipidex 1000 (Sigma Aldrich), y equipada con una camisa termostática Thermostatic JC 26/40 Jacket (GE Healthcare Life Sciences) adosada a un equipo Äkta Purifier (GE Healthcare Life Sciences). La cromatografía se llevó a cabo a un flujo de $0,5 \mathrm{ml} / \mathrm{min}$. Se midió la radiactividad de las fracciones que contenían a la proteína, antes y después de la cromatografía de interacción hidrofóbica. En caso de que la remoción de marca radiactiva no se considerara suficiente, se repitió la operación. Posteriormente, una vez colectadas todas las fracciones que contenían proteína, se les cambió el buffer (empleando un filtro Vivaspin) nuevamente hacia el buffer de fosfatos original. La muestra se sometió a una cromatografía de intercambio iónico empleando una columna MonoQ (Pharmacia Biotech Inc.) adosada a un equipo Äkta Purifier (GE Healthcare Life Sciences). La columna de intercambio iónico se estabilizó en el mismo buffer de fosfatos. La cromatografía se llevó a cabo a un flujo de $1 \mathrm{ml} / \mathrm{min}$, y luego se lavó la columna con el buffer de fosfatos suplementado con $\mathrm{KCl}$ a una concentración final de $1 \mathrm{M}$ para liberar los ácidos nucleicos unidos a la columna. Al finalizar la purificación, la proteína EgFABP1 purificada se concentró, se le midió un espectro para confirmar que estuviera libre de ácidos nucleicos y se verificó su pureza por SDS-PAGE. Las alícuotas de EgFABP1 purificada se conservaron a $-80^{\circ} \mathrm{C}$ para su posterior uso.

\subsubsection{Cuantificación de EgFABP1 purificada}

La medida de la concentración de EgFABP1 purificada se llevó a cabo midiendo la absorbancia a $280 \mathrm{~nm}$ de la muestra y empleando el coeficiente de absorción molar calculado mediante las herramientas bioinformáticas provistas por el SDSC Biology Workbench $\left(\varepsilon_{\mathrm{EgFABP} 1}=9530 \mathrm{M}^{-1} \mathrm{~cm}^{-1}\right)$. Para la determinación se tomó el espectro de absorción de la muestra entre $240 \mathrm{~nm}$ y $340 \mathrm{~nm}$ con el objetivo de advertir posibles contaminaciones con ADN (absorbancia a 260nm) y/o la presencia de agregados proteicos (dispersión de luz a 340nm). La absorbancia se midió empleando un espectrofotómetro T70+ UVNis (PG Instruments) y cubetas de cuarzo de $1 \mathrm{~cm}$ de paso óptico (Hellma). 


\subsubsection{Control de la integridad estructural de EgFABP1}

\subsubsection{Análisis por cromatografía de exclusión molecular}

Con la finalidad de determinar el estado de agregación de EgFABP1 se realizó una cromatografía empleando una columna de exclusión molecular Superdex 75 (Pharmacia Biotech Inc) adosada al equipo Äkta Purifier. Como proteínas patrón se utilizaron Albúmina Sérica Bovina (BSA, por sus siglas en inglés), Anhidrasa Carbónica (ambas de Sigma Aldrich), y una FABP recombinante purificada en nuestro laboratorio ya caracterizada (FABP intestinal, o I-FABP). Se sembraron en la columna aproximadamente $30 \mu \mathrm{g}$ de cada proteína en buffer $30 \mathrm{mM}$ Tris- $\mathrm{HCl} \mathrm{pH} \mathrm{7,4.} \mathrm{La} \mathrm{cromatografía} \mathrm{se} \mathrm{desarrolló} \mathrm{a} \mathrm{un} \mathrm{flujo} \mathrm{de} 0,5 \mathrm{ml} / \mathrm{min}$ y se siguieron los perfiles de elución mediante absorbancia a $280 \mathrm{~nm}$. El cálculo del peso molecular aparente de EgFABP1 se llevó a cabo según lo descripto por Uversky (1993).

\subsubsection{Análisis por dicroísmo circular}

Se obtuvieron espectros de dicroísmo circular de EgFABP1 purificada empleando un espectropolarímetro Jasco J-810 (Jasco Corporation) del Instituto de Química y Fisicoquímica Biológica (Universidad de Buenos Aires). Las medidas fueron llevadas a cabo con la asistencia de la Dra. Gisela R. Franchini (INIBIOLP, UNLP-CONICET). Los espectros en el UV cercano (250-320nm) o en el UV lejano (190-250nm) fueron medidos empleando cubetas rectangulares de cuarzo (Starna) de $1 \mathrm{~cm}$ y $1 \mathrm{~mm}$ de paso óptico, respectivamente. En el UV cercano se colectaron tres espectros, que fueron promediados, empleando una concentración de EgFABP1 de $43 \mu \mathrm{M}$. Para el UV lejano se procedió de la misma manera, pero con la mitad de la concentración de proteína. Los espectros fueron colectados a una velocidad de $20 \mathrm{~nm} / \mathrm{min}$, con un tiempo de respuesta de $1 \mathrm{seg}$. Para los espectros en el UV cercano se utilizó sensibilidad alta, mientras que para el UV lejano se empleó sensibilidad estándar. Como control, se registró el espectro en el UV lejano de I-FABP empleando una concentración de proteína de $19 \mu \mathrm{M}$. En todos los casos, las proteínas se encontraban en buffer $20 \mathrm{mM}$ Tris- $\mathrm{HCl}$ de $\mathrm{pH} 7,4$. La elipticidad molar de las muestras se calculó según lo descripto por Schmid (Schmid, 1997). 


\subsection{Análisis de la interacción de EgFABP1 con ligandos}

\subsubsection{Análisis de lípidos de Escherichia coli unidos a EgFABP1 recombinante}

\subsubsection{Extracción de los lípidos con solventes orgánicos}

Para realizar la extracción de lípidos a partir de EgFABP1 recombinante, se purificó la proteína tal como se describió previamente (ítem 2.1.2.3) pero exceptuando el paso de deslipidización. La extracción se llevó a cabo aplicando el método descripto por Folch (Folch et al., 1957) con modificaciones. Brevemente, se tomaron $4 \mathrm{ml}$ de EgFABP1 purificada (conteniendo aproximadamente $2 \mathrm{mg}$ de proteína) y se separaron en 4 tubos de vidrio con tapa esmerilada. A cada fracción (de $1 \mathrm{ml}$ ) se le agregaron $5 \mathrm{ml}$ de mezcla de Folch (cloroformo:metanol en proporción 2:1). Se agitó la mezcla en vortex durante 15min. Las muestras se filtraron, y cada filtrado se colectó en un tubo nuevo conteniendo $250 \mu \mathrm{l}$ de solución $0,5 \mathrm{M}$ de $\mathrm{NaCl}$. Los tubos se centrifugaron durante 15min a 2000rpm en una centrifuga UV (International Equipment Centrifuge), empleando el rotor 279. Se descartó la fase superior por aspiración, y se transfirió la inferior a un balón de vidrio. Se evaporó el solvente en corriente de $\mathrm{N}_{2}$, y se resuspendieron los lípidos en $4 \mathrm{ml}$ de cloroformo. Las muestras se conservaron en viales color caramelo bajo atmósfera de $\mathrm{N}_{2}$ a $-20^{\circ} \mathrm{C}$ hasta su posterior análisis.

\subsubsection{Cromatografía en capa fina}

Para la cromatografía en capa fina (TLC, por sus siglas en inglés) se concentraron los lípidos extraídos según lo descripto en el ítem 2.2.1.1, secando los mismos en corriente de $\mathrm{N}_{2}$ y resuspendiéndolos en $500 \mu \mathrm{l}$ de cloroformo. Las placas utilizadas fueron placas de $20 \mathrm{~cm} \mathrm{x}$ $20 \mathrm{~cm}$ de Silicagel 60 (Merck). La siembra de la muestra se llevó a cabo empleando una microjeringa de $10 \mu \mathrm{l}$ (Hamilton). Se sembraron $10 \mu \mathrm{l}$ de muestra a $1 \mathrm{~cm}$ del borde inferior de la placa, y se desarrolló la TLC en una cuba cromatográfica saturada con los vapores de la fase móvil. La fase móvil empleada, para separación de lípidos neutros, consistió en la mezcla Hexano:Dietiléter:Ácido Acético en una proporción 80:20:1 (v:v:v). Se utilizó como estándar, una extracción de lípidos de hígado de rata. La placa se reveló mediante pulverización con una solución al $8 \% \mathrm{CuSO}_{4}$ en $10 \% \mathrm{H}_{3} \mathrm{PO}_{4}$, seguida de incubación a $140^{\circ} \mathrm{C}$ hasta la aparición de color, según lo descripto en Obal et al., 2012. La imagen de la placa se digitalizó empleando un escáner convencional. 


\subsubsection{Cromatografía gas-líquido}

Para llevar a cabo la cromatografía gas-líquido (GLC, por sus siglas en inglés), se derivatizaron los ácidos grasos empleando $\mathrm{BF}_{3}$-metanol según lo descripto en Morrison \& Smith (1964), con modificaciones. El protocolo consistió en evaporar el solvente de las muestras de ácidos grasos extraídos de EgFABP1 empleando $\mathrm{N}_{2}$. Seguidamente, se agregaron $2 \mathrm{ml}$ de solución $10 \% \mathrm{BF}_{3}$ en metanol, se gasearon los tubos con $\mathrm{N}_{2}$ y se colocó en un bloque termostático a $64^{\circ} \mathrm{C}$ durante 3 horas. Una vez fríos los tubos, se les agregaron $3 \mathrm{ml}$ de cloroformo y se agitó bien. Luego se agregaron $2 \mathrm{ml}$ de agua bidestilada y se agitó nuevamente. Se centrifugaron los tubos a baja velocidad para separar las fases (como se explicó en el ítem 2.2.1.1). Se descartó la fase superior y se lavó la fase clorofórmica dos veces con $2 \mathrm{ml}$ de agua bidestilada cada vez. Finalmente, se secó el extracto clorofórmico bajo corriente de $\mathrm{N}_{2}$ y se resuspendieron los ésteres metílicos de ácidos grasos (FAMEs, por sus siglas en inglés) en $n$-hexano. Los FAMEs se analizaron por GLC empleando un equipo $H P$ 6890 (Hewlett-Packard) según lo descripto en Maté et al. (2004).

\subsubsection{Análisis de la interacción con ligandos por proteólisis parcial de EgFABP1}

\subsubsection{Digestión parcial de EgFABP1 empleando la proteasa ArgC}

La proteasa ArgC (Sigma Aldrich) fue preincubada en buffer de fosfatos (descripto en el ítem 2.1.2.3) con $1 \mathrm{mM}$ DTT durante 2 horas a $30^{\circ} \mathrm{C}$. Por otra parte, se preincubó EgFABP1 durante $30 \mathrm{~min}$ a $37^{\circ} \mathrm{C}$ con diferentes ácidos grasos: ácido mirístico (14:0); ácido palmítico (16:0); ácido esteárico (18:0) y ácido oleico (18:1 n-9), en una relación molar ligando:proteína de 4:1. Los diferentes ácidos grasos se disolvieron en etanol, por lo que se incluyó como control un tubo con EgFABP1 preincubada con etanol a la misma concentración final que en los tubos que contenían los ligandos. Una vez pasado el tiempo de incubación con los ácidos grasos, y previo al agregado de la proteasa, se incubaron los diferentes tubos conteniendo EgFABP1 con $1 \mathrm{mM}$ DTT durante $15 \mathrm{~min}$ más a $30^{\circ} \mathrm{C}$. Se agregó la solución de proteasa a los tubos, en una relación EgFABP1:ArgC de 20:1 (en masa). Se incubaron las muestras a $30^{\circ} \mathrm{C}$ y se retiraron alícuotas a los $5 \mathrm{~min}$ de iniciada la digestión, y luego de una incubación ON. Paralelamente, se trató una muestra de EgFABP1 de la misma manera, pero sin agregarle proteasa. Las alícuotas obtenidas se congelaron a $-20^{\circ} \mathrm{C}$ hasta su posterior análisis. 


\subsubsection{Análisis por electroforesis Tricina-SDS-PAGE}

El análisis de las muestras digeridas con $\operatorname{ArgC}$ se realizó mediante electroforesis desnaturalizante empleando buffers de Tris-Tricina. Se emplearon geles discontinuos que consistieron en gel separador de $16,5 \% \mathrm{~T} 6 \% \mathrm{C}$, gel espaciador de $10 \% \mathrm{~T} 3 \% \mathrm{C}$ y gel concentrador de $4 \% \mathrm{~T} 3 \% \mathrm{C}$, donde $\% \mathrm{~T}$ representa la concentración total de monómero (acrilamida + bisacrilamida) y \%C representa la concentración de crosslinker (bisacrilamida) respecto de la concentración total de monómero. El buffer utilizado para la preparación de los geles contiene $3 \mathrm{M}$ Tris, 0,3\%SDS, pH 8,45. Los geles, de $1 \mathrm{~mm}$ de espesor, se prepararon empleando el equipo MiniProtean Tetracell (BioRad). Las muestras fueron preparadas hirviéndolas durante $5 \mathrm{~min}$ en buffer de siembra. La composición de dicho buffer fue: $50 \mathrm{mM}$ Tris, 4\% SDS, 12\% (P/V) Glicerol, 2\% (V/V) $\beta$-mercaptoetanol, 0,01\% Coomassie Brilliant Blue G-250, pH 6,8. La electroforesis se llevó a cabo a 50V durante $30 \mathrm{~min}$, seguido de $100 \mathrm{~V}$ hasta que el frente de corrida hubiera avanzado lo suficiente (aproximadamente 2,5 horas). Como buffer catódico se empleó un buffer compuesto por 0,1M Tris, 0,1M Tricina y 0,1\% SDS, y como buffer anódico uno compuesto por Tris $0,2 \mathrm{M} \mathrm{pH} 8,9$. La tinción de los geles y la colección de imágenes se llevaron a cabo tal como se describió en el ítem 2.1.2.2.

\subsubsection{Análisis por dicroísmo circular de la interacción de EgFABP1 con ácidos grasos}

De modo similar a lo descripto en el ítem 2.1.3.2, se obtuvieron espectros de dicroísmo circular de EgFABP1 purificada, en sus formas apo-EgFABP1 (libre de ligandos) y holoEgFABP1 con ácido palmítico o ácido oleico. El equipo empleado fue el mismo espectropolarímetro Jasco J-810 (Jasco Corporation) del Instituto de Química y Fisicoquímica Biológica (UBA) mencionado previamente. Estas medidas también se realizaron bajo la supervisión de la Dra. Gisela R. Franchini (INIBIOLP, UNLP-CONICET). Las cubetas utilizadas fueron las mismas cubetas ya descriptas de cuarzo de $1 \mathrm{~cm}$ y $0,1 \mathrm{~cm}$ de paso óptico, para los espectros medidos en el UV cercano y lejano, respectivamente. Las mediciones consistieron en la colección de tres espectros, los cuáles fueron promediados. Se empleó una concentración de EgFABP1 de 31,6 MM. Los espectros fueron colectados a una velocidad de $20 \mathrm{~nm} / \mathrm{min}$, con un tiempo de respuesta de $1 \mathrm{seg}$. Para los espectros en el UV cercano (250$320 \mathrm{~nm}$ ) se utilizó sensibilidad alta, mientras que para el UV lejano (200-250) se empleó sensibilidad estándar. Para obtener las formas holo-EgFABP1, se incubó a la proteína con los respectivos ácidos grasos $(A G)$ en una relación molar EgFABP1:AG de 1:4 durante 40 minutos a $37^{\circ} \mathrm{C}$. Los $A G$, se agregaron a partir de soluciones $10 \mathrm{mM}$ en Etanol. En todos los casos, las 
proteínas se encontraban en buffer PBS (137mM NaCl; $10 \mathrm{mM} \mathrm{Na}_{2} \mathrm{HPO}_{4} ; 1,8 \mathrm{mM} \mathrm{KH}_{2} \mathrm{PO}_{4}$; $\left.1 \mathrm{mM} \mathrm{NaN}_{3} ; \mathrm{pH} 7,4\right)$. La elipticidad molar de las muestras se calculó según lo descripto por Schmid (Schmid, 1997).

\subsubsection{Análisis de la interacción de EgFABP1 con análogos fluorescentes de ácidos grasos}

La unión de análogos fluorescentes de ácidos grasos a EgFABP1 se llevó a cabo empleando un ensayo de titulación fluorimétrica, tal como se describió en Córsico et al. (2004). Brevemente, el ensayo consistió en incubar $0,5 \mu \mathrm{M}$ de un antroiloxi-ácido graso a $25^{\circ} \mathrm{C}$ durante 3 min con concentraciones crecientes de EgFABP1. El buffer utilizado para la titulación fue el buffer TBS, cuya composición consiste en 40mM Tris (Trizma, Sigma Aldrich), 100mM NaCl, pH 7,4. Los antroiloxi-ácidos grasos (AOFA) empleados para los ensayos fueron el ácido 12(9-antroiloxi)-esteárico y el ácido 16-(9-antroiloxi)-palmítico, 12AS y 16AP respectivamente. Los espectros de emisión fueron registrados entre $400 \mathrm{~nm}$ y $500 \mathrm{~nm}$ empleando un espectrofluorómetro Fluorolog-3 (Horiba-Jobin Yvon). La longitud de onda de la luz empleada para la excitación, $\lambda_{\text {exc }}$, fue de $383 \mathrm{~nm}$. Para estos ensayos se emplearon cubetas de cuarzo para fluorescencia de $1 \mathrm{~cm}$ de paso óptico (Hellma).

La constante de disociación se define como:

$$
K_{D}=\frac{[E g F A B P 1][A O F A]}{[A O F A-E g F A B P 1]}
$$

A partir del equilibrio:

$$
E g F A B P 1+A O F A \leftrightarrow A O F A-E g F A B P 1
$$

En donde [EgFABP1] y [AOFA] representan las concentraciones en el equilibrio de proteína y ligando libres, y [AOFA-EgFABP1] la del complejo ligando-proteína.

Los datos fueron analizados empleando el software Microcal ORIGIN. Para el ajuste se empleó un modelo de equilibrio exacto de n-sitios de unión, tal como ha sido descripto previamente (McDermott et al., 2001). La ecuación utilizada para el ajuste es la siguiente:

$$
F=F_{1}+\left(F_{2}-F_{1}\right)\left(\frac{\left(C_{L}+n C_{P}+K_{D}\right)-\sqrt{\left(C_{L}+n C_{P}+K_{D}\right)^{2}-4 n C_{P} C_{L}}}{2 C_{L}}\right)
$$

En donde $C_{P}$ representa la concentración de proteína, $C_{\llcorner}$representa la concentración total de ligando, $n$ es el número de sitios de unión, $\mathrm{K}_{\mathrm{D}}$ es la constante de disociación, $\mathrm{F}_{1}$ es la 
fluorescencia del ligando en ausencia de proteína, y $F_{2}$ la fluorescencia al alcanzar la saturación.

\subsection{Análisis de la interacción de EgFABP1 con membranas}

\subsubsection{Preparación de vesículas unilamelares pequeñas}

La preparación de vesículas unilamelares pequeñas (SUVs) se llevó a cabo aplicando el protocolo descripto por Kleinfeld \& Storch (1993). Brevemente, se mezclaron los fosfolípidos adecuados, de acuerdo a la composición de las vesículas de interés, en un balón de vidrio; se secaron bajo corriente de $\mathrm{N}_{2}$, y se liofilizaron $\mathrm{ON}$ protegidos de la luz. Se resuspendieron los lípidos en buffer TBS, o TBS + 1mM EDTA en caso de SUVs que contienen cardiolipina (CL); se incubaron durante $15 \mathrm{~min}$ a $37^{\circ} \mathrm{C}$, con agitación, y luego se sometió la mezcla a ultrasonido. Para ello, se utilizó un sonicador de punta S-450 (Branson) con punta chata. Se empleó un ciclo de trabajo de $70 \%$ a una potencia de entre 3 y 4 durante $45 \mathrm{~min}$. Durante dicho proceso, los lípidos (ubicados en un recipiente adecuado, con camisa termostatizada) se mantuvieron refrigerados por una corriente de agua/hielo, y bajo corriente de $\mathrm{N}_{2}$ para evitar su oxidación. Posteriormente, se centrifugó la muestra, a $4^{\circ} \mathrm{C}$, durante $45 \mathrm{~min}$ a $45000 \mathrm{rpm}$, empleando un rotor 70.1Ti en una ultracentrífuga Optima LE-80K (Beckman Coulter). El sobrenadante obtenido, conteniendo las SUVs, se conservó en tubos de vidrio color caramelo a $4^{\circ} \mathrm{C}$ bajo atmósfera de $\mathrm{N}_{2}$ para su posterior uso. La cuantificación de las vesículas (como concentración final de fosfolípidos) se llevó a cabo empleando la técnica descripta por Gomori (1942) para determinación de fósforo inorgánico. Para llevar a cabo dicha técnica, se mezclaron las muestras de trabajo, y muestras con distintas cantidades de una solución patrón $1 \mathrm{mM}$ $\mathrm{NaH}_{2} \mathrm{PO}_{4}$ que se utilizaron para armar una curva de calibración, con $30 \mu \mathrm{l}$ de una solución al $10 \%$ de $\mathrm{Mg}\left(\mathrm{NO}_{3}\right)_{2}$, y se incubaron a $140^{\circ} \mathrm{C} \mathrm{ON}$. Posteriormente, se agregaron $400 \mu \mathrm{l}$ de $0,5 \mathrm{M}$ $\mathrm{HCl}$ a las muestras carbonizadas, se agitaron en vortex y se incubaron durante 30 min en un baño de agua hirviendo. Luego se agregaron 930 $\mu$ de una mezcla 6:1 (v/v) de solución de ácido molíbdico $\left(0,42 \%\right.$ molibdato de amonio tetrahidrato en $\left.1 \mathrm{~N} \mathrm{H}_{2} \mathrm{SO}_{4}\right)$ y $10 \%$ ácido ascórbico; y se incubaron las muestras a $37^{\circ} \mathrm{C}$ durante 1 hora. La absorbancia a $820 \mathrm{~nm}$ de cada muestra se midió en un espectrofotómetro T70+ UV/Vis (PG Instruments) empleando cubetas de vidrio de $1 \mathrm{~cm}$ de paso óptico (Hellma). El cálculo de la concentración de fosfolípidos en la muestra se realizó mediante la curva de calibración preparada con cantidades conocidas de $\mathrm{NaH}_{2} \mathrm{PO}_{4}$. En el caso de las vesículas con CL en su composición, la concentración de fosfolípidos debe corregirse debido a la presencia de dos grupos fosfatos por cada molécula de CL. Se prepararon SUVs de diversas composiciones de acuerdo al experimento en que fueran a ser utilizadas. Las SUVs estándar para los ensayos de 
transferencia de 12AS a membranas se prepararon mezclando $90 \mathrm{~mol} \%$ de fosfatidilcolina de huevo (EPC, por sus siglas en inglés) y $10 \mathrm{~mol} \%$ del fosfolípido fluorescente $\mathrm{N}-(7-$-nitro-2,1,3benzoxadiazol-4-yl)-fosfatidilcolina (NBD-PC), que actúa como quencher de la fluorescencia del grupo antroiloxi del 12AS. Para aumentar la densidad de carga negativa de las vesículas aceptoras, se reemplazó un $25 \mathrm{~mol} \%$ de EPC por una cantidad equimolar de fosfatidilserina (PS, por sus siglas en inglés) o CL. Para el ensayo de interacción con membranas por competencia con citocromo c (CitC) se prepararon SUVs conteniendo $64 \mathrm{~mol} \%$ EPC, $10 \mathrm{~mol}$ $\%$ fosfatidiletanolamina de huevo (EPE), $25 \mathrm{~mol} \% \mathrm{CL}$ y $1 \mathrm{~mol} \%$ dansil-fosfatidiletanolamina (DPE). DPE es un fosfolípido con un grupo dansilo fluorescente cuya fluorescencia es apagada por interacción con el grupo hemo del CitC.

\subsubsection{Determinación del coeficiente de partición (KP) de 12AS entre EgFABP1 y SUVs}

El coeficiente de partición del 12AS entre EgFABP1 y SUVs conteniendo NBD se determinó midiendo la fluorescencia del complejo 12AS-EgFABP1 para diferentes concentraciones de SUVs (preparadas según lo descripto en el ítem 2.3.1). Brevemente, se incubaron $10 \mu \mathrm{M}$ EgFABP1 y $1 \mu \mathrm{M} 12 \mathrm{AS}$ en buffer TBS a $25^{\circ} \mathrm{C}$, se registró la emisión de fluorescencia del 12AS $\left(\lambda_{\mathrm{em}}=440 \mathrm{~nm} ; \lambda_{\mathrm{exc}}=383 \mathrm{~nm}\right)$ y luego se agregaron concentraciones crecientes de SUVs, incubando la mezcla durante $3 \mathrm{~min}$ antes de colectar los espectros de emisión (Massey et al., 1997). El coeficiente de partición relativo $\left(K_{P}\right)$ se define como:

$$
K_{P}=\frac{[12 A S-E g F A B P 1]}{[E g F A B P 1]} \times \frac{[S U V]}{[12 A S-S U V]}
$$

Donde [12AS-EgFABP1] y [12AS-SUV] son las concentraciones de $12 \mathrm{AS}$ unido a la proteína o las vesículas, respectivamente; y [EgFABP1] y [SUV] son las concentraciones de proteína y vesículas. Tal como se mencionó en el ítem 2.3.1, la molécula de NBD presente en el fosfolípido NBD-PC de las vesículas es un quencher de la fluorescencia del 12AS, por lo que la emisión de fluorescencia de este último disminuye al ser transferido a las vesículas. La disminución de la fluorescencia del 12AS en función del aumento de la [SUV] se relaciona con el KP según:

$$
F_{\text {rel }}=\frac{a \times K_{P}}{K_{P}+\frac{[S U V]}{[E g F A B P 1]}}-b \times \frac{[S U V]}{[E g F A B P 1]}
$$


Donde $\mathrm{F}_{\text {rel, }}$ [SUV], [EgFABP1], $\mathrm{K}_{\mathrm{P}}$, a y $b$ son la fluorescencia relativa, la concentración molar de SUV, la concentración molar de EgFABP1, el coeficiente de partición, y parámetros de ajuste, respectivamente (De Gerónimo et al., 2010). El coeficiente de partición se utilizó para establecer las condiciones para los ensayos de transferencia de 12AS de modo de asegurar una transferencia unidireccional.

\subsubsection{Determinación de la velocidad de transferencia de 12AS desde EgFABP1 a SUVs}

La determinación de la velocidad de transferencia de 12AS desde EgFABP1 a SUVs se realizó empleando un ensayo de transferencia de energía de resonancia de Förster, o FRET (del inglés, Förster Resonance Energy Transfer), como fue descripto para otras FABPs (Storch \& Bass, 1990; Hsu \& Storch, 1996; Córsico et al., 1998). Para este ensayo se utilizó un módulo de mezclado rápido stopped-flow RX2000 (Applied Photophysics Ltd.) adosado al espectrofluorómetro Fluorolog 3. Este equipo permite mezclar casi instantáneamente dos soluciones, y simultáneamente activa el registro de la fluorescencia por parte del espectrofluorómetro al que está acoplado. De este modo, se mezcló el complejo EgFABP112AS (en relación molar 15:1, de modo que no quede más de un $1 \%$ de ligando libre) con SUVs conteniendo NBD-PC, a $25^{\circ} \mathrm{C}$, empleando distintas relaciones molares SUV:EgFABP1 de modo de garantizar una transferencia unidireccional del ligando, teniendo en cuenta el valor de $K_{P}$ obtenido como se describió en el ítem 2.3.2. Al mezclar, la transferencia del 12AS desde EgFABP1 a las SUVs se monitorea como una caída en función del tiempo de la fluorescencia del 12AS (debido a que su fluorescencia es inactivada por el NBD de las vesículas). Las diferentes proporciones SUV:EgFABP1 utilizadas fueron (en relación molar) 10:1, 20:1 y 40:1. En estos experimentos, se emplearon SUVs con diferentes composiciones (como se describió en el ítem 2.3.1), así como variantes del buffer TBS con concentraciones crecientes de $\mathrm{NaCl}$. Se realizaron controles de fotoblanqueo (o photobleaching) previos a cada experimento, tal como se describió en Córsico et al. (1998). Los datos se analizaron empleando SigmaPlot. Para cada condición experimental dentro de un experimento, se realizaron al menos cinco réplicas. 


\subsubsection{Determinación de la unión de EgFABP1 a SUVs por competencia con citocromo c}

Para analizar la posible asociación de EgFABP1 con membranas fosfolipídicas artificiales se empleó un ensayo basado en la capacidad del citocromo c (CitC) de unirse a membranas acídicas (Mustonen et al., 1987). La unión de CitC a membranas acídicas conteniendo DPE (Ver ítem 2.3.1) se monitoreó siguiendo la fluorescencia del grupo dansilo de dicha sonda. Una caída en su fluorescencia se corresponde con la unión del CitC a la membrana, ya que su grupo hemo es un quencher de la fluorescencia del grupo dansilo. La capacidad de EgFABP1 de interactuar con las membranas se evidenció como una disminución de la supresión de la fluorescencia del DPE inducido por el CitC. Inicialmente, se analizó la disminución de la fluorescencia del grupo dansilo en función de agregados crecientes de CitC con la finalidad de determinar la concentración mínima de CitC necesaria para causar la máxima disminución de la fluorescencia del DPE. Para ello, se incubaron $15 \mu \mathrm{M}$ de DPE-SUVs con concentraciones crecientes de CitC (Sigma Aldrich) y se registró, para cada condición, la fluorescencia del grupo dansilo ( $\left.\lambda_{\mathrm{exc}}=335 \mathrm{~nm} ; 450 \mathrm{~nm} \leq \lambda_{\mathrm{em}} \leq 600 \mathrm{~nm}\right)$. Una vez determinada la concentración de CitC a utilizar, se procedió a evaluar la interacción de EgFABP1 con las

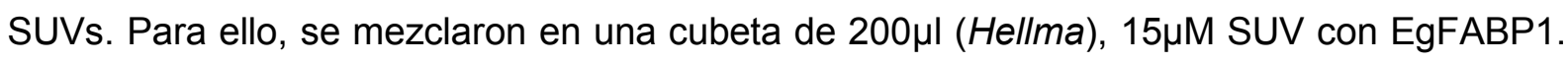
Luego de 2 min de incubación, se registró la fluorescencia a 520nm del DPE. Seguidamente, se incorporó a la mezcla $1 \mu \mathrm{M}$ de CitC, se incubó por 2 min más, y se midió nuevamente la fluorescencia a 520nm. El procedimiento se repitió para cada una de las concentraciones de EgFABP1 utilizadas. El buffer utilizado fue 20mM Tris-HCl, 0,1mM EDTA, pH 7,4.

\subsection{Identificación y análisis de FABPs de E. multilocularis}

\subsubsection{Análisis bioinformático del genoma de $E$. multilocularis}

Para el análisis bioinformático del genoma de E. multilocularis se contó con la asistencia del Dr. Ferenc Kiss (Universidad de Wurzburgo, Alemania). La búsqueda de las FABPs de $E$. multilocularis se llevó a cabo empleando el programa informático BioEdit (http://www.mbio.ncsu.edu/BioEdit/bioedit.html), y los programas incluídos en el mismo. Como punto de partida para el análisis se tomaron las secuencias de EgFABP1 y EgFABP2 publicadas por el grupo de la Dra. Esteves (Esteves et al. 1993, Esteves et al. 2003), disponibles en las bases de datos del GenBank (http://www.ncbi.nlm.nih.gov/genbank/) bajo los números de acceso AF321119.1 y AF321117.1, respectivamente. Se emplearon las herramientas BLASTN, TBLASTN, BLASTX y BLASTP para comparar las secuencias de 
EgFABP1 y EgFABP2, tanto con el borrador del genoma de E. multilocularis disponible en el laboratorio del Dr. Brehm (antes de la publicación de dicho genoma por Tsai et al., 2013), como con datos de transcriptómica, tanto de dicho organismo como de cestodos relacionados, y con bases de datos de proteínas predichas in silico. La versión del genoma empleada para realizar las búsquedas fue la versión "emu.contigs_171109" generada por Wellcome Trust Sanger Institute. Actualmente, dicha versión, así como otras posteriores, se encuentran disponibles en ftp://ftp.sanger.ac.uk/pub/project/pathogens/Echinococcus/multilocularis/ genome/ARCHIVE/.

\subsubsection{Diseño de siRNAs contra EmFABP1 y EmFABP2}

El diseño de los siRNAs se llevó a cabo empleando el programa BLOCK-iT RNAi (https://rnaidesigner.invitrogen.com/rnaiexpress/). Se seleccionó un siRNA dirigido contra emfabp1 y uno contra emfabp2 (genes ortólogos a egfabp1 y egfabp2, respectivamente), a los cuáles se les eliminaron dos bases de sus extremos 3', según lo descripto por Spiliotis et al. (2010). Se chequeó mediante BLAST que cada siRNA seleccionado tuviera como blanco exclusivamente al gen contra el cual se había diseñado. Como control, se utilizó el mismo siRNA empleado por Spiliotis et al. (2010), dirigido contra el ARN mensajero de la proteína verde fluorescente (GFP) de Aequorea victoria, que no cuenta con genes ortólogos en $E$. multilocularis. Los siRNA se compraron a Sigma Aldrich. Las secuencias de los siRNAs correspondientes se detallan en el Apéndice 7.1.2.

\subsubsection{Obtención, aislamiento y cultivo de células de E. multilocularis}

La obtención de células primarias de E. multilocularis para los ensayos de silenciamiento se realizó a partir de vesículas (metacestodos) obtenidas en co-cultivo con células Reuber $\mathrm{RH}$ - de hepatoma de rata (ATCC no. CRL-1600), gentilmente cedidas por el Dr. Uriel Koziol (Universidad de Wurzburgo, Alemania). Las mismas tenían al menos tres meses de cultivo en las condiciones mencionadas y provenían de material parasitario extraído a partir de gerbos (organismo utilizado como hospedador de laboratorio de E. multilocularis). Se utilizó material correspondiente al aislamiento GH09 en un caso, y JAVA en otro. Para el aislamiento de las células primarias de E. multilocularis se empleó el protocolo descripto por Spiliotis et al., (2010). Brevemente, el mismo consistió en realizar inicialmente un cultivo ON de vesículas de metocestodo en atmósfera de $\mathrm{N}_{2}$ y con condiciones reductoras para propiciar la eliminación de las células de hepatoma de rata que pudieran haber quedado en el cultivo luego de los reiterados lavados con PBS efectuados a las vesículas. Para dicho cultivo se empleó el medio 
condicionado "cDMEM" (Dulbecco's MEM (Biochrom AG) $+10 \%$ suero fetal bovino inactivado (Biochrom AG) + 200 unidades/ml PenStrep (Gibco), condicionado por una semana en presencia de células Reuber $\mathrm{RH}-$ ) adicionado, luego de esterilizar, con $10 \mu \mathrm{M}$ batocuproina disulfonato, $1 \mu \mathrm{l} / \mathrm{ml} \beta$-mercaptoetanol y $100 \mu \mathrm{M}$ L-cisteína. Las botellas de cultivo se gasearon con $\mathrm{N}_{2}$. La incubación se realizó en una estufa gaseada a $37^{\circ} \mathrm{C}$ con $5 \% \mathrm{CO}_{2}$. Al día siguiente, se lavaron las vesículas exhaustivamente con PBS y se las escurrió con ayuda de un aro de metal con gasa, tal como se describe en Spiliotis \& Brehm (2009), con la finalidad de retirar la mayor cantidad de PBS posible. Seguidamente, se rompieron las vesículas por pipeteo empleando una pipeta de $10 \mathrm{ml}$. Se estimó el volumen de vesículas rotas empleando la graduación del tubo cónico en el cual fueron colectadas. Se llevó a cabo una centrifugación de 6 minutos a $600 \times \mathrm{g}$ en rotor de ángulo fijo. El sobrenadante resultante se retiró con pipeta. Se lavaron los pellets exhaustivamente con PBS, hasta que el sobrenadante se observara traslúcido. Se centrifugó nuevamente a $600 \times \mathrm{g}$ durante 6 minutos, y se descartó el sobrenadante, retirándolo con pipeta. Los pellets se resuspendieron en 4 volúmenes de tripsina/EDTA, se agitaron suavemente los tubos, y se incubaron a $37^{\circ} \mathrm{C}$ durante 25 minutos aproximadamente. A continuación, se realizó un filtrado empleando gasa de $30 \mu \mathrm{m}$ de poro adosada a un vaso de precipitados. Luego de pasar toda la suspensión por la gasa, se enjuagó la misma con PBS y se colectaron los restos retenidos en ella en un tubo cónico. A eso se le agregaron $5 \mathrm{ml}$ de tripsina/EDTA, se agitó más fuertemente que la vez anterior, y se incubó a $37^{\circ} \mathrm{C}$ durante 5 minutos. Dicha operación se repitió 3 veces. El líquido filtrado, colectado en el vaso de precipitados, se volvió a filtrar a través de gasa nueva. El filtrado resultante se centrifugó durante 1 minuto a $100 \times \mathrm{g}$ en rotor oscilante, para eliminar los corpúsculos calcáreos. Los sobrenadantes colectados se centrifugaron a 400 x g durante 10 minutos en rotor oscilante. Se descartaron los sobrenadantes y se resuspendieron los pellets en PBS en un volumen tal que fuera la mitad del volumen estimado de vesículas rotas obtenidas. A continuación, se tomaron $12,5 \mu \mathrm{l}$ de muestra y se diluyeron con $1 \mathrm{ml}$ de PBS, para luego medirles la $\mathrm{DO}$ a $600 \mathrm{~nm}$. Una $\mathrm{DO}_{600}=0,02$ se define como 1 unidad (U). De este modo, teniendo en cuenta la medida realizada, se sembraron $500 \mathrm{U}$ por pocillo en placas de 6 pocillos, cada uno conteniendo $4 \mathrm{ml}$ de medio cMEM suplementado con $\beta$-mercaptoetanol y Lcisteína como se describió previamente, pero sin batocuproína disulfato. Las células se resuspendieron suavemente con pipeta $\mathrm{P} 1000$, y se colocó la placa dentro de una bolsa tipo Ziploc. Se gaseó la bolsa 2 veces con $\mathrm{N}_{2}$ y se cerró. Se realizó una incubación $O N$ a $37^{\circ} \mathrm{C}$, con $5 \% \mathrm{CO}_{2}$. 


\subsubsection{Electroporación de células de E. multilocularis}

El día posterior al aislamiento de las células primarias de E. multilocularis, y como paso previo a la electroporación de las mismas, se juntaron las células de dos pocillos de la placa en uno solo, y se incubaron durante 3 horas a $37^{\circ} \mathrm{C}$ en las mismas condiciones que antes. Pasado dicho tiempo, se colectaron las células y se centrifugaron durante 5 minutos a $100 \mathrm{x}$ g. El sobrenadante se retiró con pipeta y se descartó. Se resuspendió cada pellet en $2 \mathrm{ml}$ de buffer de electroporación (120mM Trehalosa, 20mM HEPES, $1 \mathrm{mM}$ Mioinositol, $1 \mathrm{mM} \mathrm{KCl}, 1 \mathrm{mM}$ $\mathrm{MgCl}_{2}, 1 \mathrm{mM} \mathrm{K}_{2} \mathrm{HPO}_{4}, 0,4 \mathrm{mM} \mathrm{KH} \mathrm{PO}_{4}, 1 \mathrm{mM}$ Glutatión; $\mathrm{pH} 6,9$; conductividad <1,3mS), de modo de obtener una suspensión de $0,5 \mathrm{U} / \mu \mathrm{l}$ (Ver ítem 2.4.3). Por cada $50 \mathrm{U}$ se aplicó $1 \mu \mathrm{g}$ de siRNA. La electroporación se llevó a cabo en cubetas de $2 \mathrm{~mm}$, aplicando $400 \mathrm{~V}$ y $1 \mu \mathrm{F}$ mediante un electroporador GenePulser (BioRad). Luego de la electroporación, se incubaron las células durante 10 minutos a $37^{\circ} \mathrm{C}$, se centrifugaron a $100 \mathrm{xg}$ durante 5 minutos y se descartó el sobrenadante. Las células se resuspendieron en $200 \mu \mathrm{l}$ de medio cDMEM con Lcisteína y $\beta$-mercaptoetanol, y se sembraron en placa de 96 pocillos. La placa se incubó a $37^{\circ} \mathrm{C}$ en atmósfera de $\mathrm{N}_{2}$, tal como se describió en el ítem 2.4.3. El medio de cultivo fue cambiado cada dos días aproximadamente.

\subsubsection{Monitoreo de los niveles de expresión de las FABPs de E. multilocularis}

Para analizar los niveles de expresión de las FABPs de E. multilocularis se llevaron a cabo experimentos de Western Blot y RT-PCR (reacción en cadena de la polimerasa con transcripción reversa) semicuantitativa.

\subsubsection{Extracción de proteínas}

Para la extracción de proteínas, se colectaron las muestras a partir de los pocillos de la placa en la que se realizaron los cultivos, se colocaron en tubos tipo eppendorf de $1,5 \mathrm{ml}$ y se centrifugaron durante 5 minutos a $100 \times$ g. Se descartaron los sobrenadantes, y se resuspendieron los pellets en $100 \mu \mathrm{l}$ cada uno de buffer de siembra sin $\beta$-mercaptoetanol. Se hirvieron las muestras durante 10 minutos a $100^{\circ} \mathrm{C}$ y luego se centrifugaron durante 10 minutos a $10000 \mathrm{x}$ g. Los sobrenadantes se conservaron a $-20^{\circ} \mathrm{C}$ para su posterior análisis. 


\subsubsection{SDS-PAGE/Western Blot}

Para llevar a cabo el análisis por Western Blot de los niveles de expresión de las FABPs de E. multilocularis se realizó primeramente una electroforesis SDS-PAGE de las muestras de proteínas obtenidas según lo descripto en el ítem 2.4.5.1. Dichas muestras se cuantificaron empleando el kit BCA Protein Assay Kit (Pierce) según las indicaciones del fabricante, de modo de sembrar en el gel aproximadamente $2 \mu \mathrm{g}$ totales de proteína por muestra. El protocolo de SDS-PAGE empleado fue similar al descripto en el ítem 2.1.2.2. Las muestras se corrieron durante una hora a 150V. Seguidamente, se realizó la transferencia de las muestras a membranas de nitrocelulosa empleando un equipo de transferencia húmeda Mini Trans-Blot (BioRad). La transferencia se llevó a cabo a 350mA durante una hora. Luego de la transferencia se bloquearon las membranas durante una hora a temperatura ambiente con una solución al $5 \%$ de leche en polvo descremada preparada en buffer TBST (20mM Tris, $150 \mathrm{mM} \mathrm{NaCl}, 0,1 \%$ Tween 20, $\mathrm{pH}$ 8). Posteriormente, se incubaron las membranas $\mathrm{ON} \mathrm{a} 4^{\circ} \mathrm{C}$, con agitación, con el anticuerpo monoclonal de ratón a-Elp diluido 1:1000 en buffer TBST + $5 \%$ leche. Seguidamente, se realizaron 3 lavados de 10 minutos cada uno con buffer TBST, y se incubaron las membranas durante 1 hora a temperatura ambiente con anticuerpos $\alpha$ inmunoglobulinas de ratón conjugado a peroxidasa, diluidos en buffer TBST + 5\% leche según indicaciones del fabricante. Luego de hacer 3 lavados de 10 minutos cada uno con buffer TBST, se revelaron los Western Blots empleando el reactivo SuperSignal West Pico Chemiluminescent Substrate (Pierce) y placas radiográficas. Una vez obtenidos los resultados, se lavaron las membranas durante 5 minutos en buffer TBST y se incubaron durante 3 horas a $50^{\circ} \mathrm{C}$ en buffer de stripping (20mM Tris, $2 \%$ SDS, 0,7\% $\beta$-mercaptoetanol, $\mathrm{pH} 6$,8) para remover los anticuerpos. A continuación, se realizaron 3 lavados de 10 minutos cada uno con buffer TBST, se bloquearon las membranas durante 1 hora a temperatura ambiente con $5 \%$ de leche en buffer TBST, y se repitió el protocolo descripto utilizando el anticuerpo a-EgFABP1 (Ver Apéndice 7.4) diluido 1:20000 en buffer TBST + 5\% leche, como anticuerpo primario, y un anticuerpo a-inmunoglobulinas de conejo conjugado a peroxidasa, diluido 1:5000 en el mismo buffer. Las imágenes obtenidas fueron escaneadas y analizadas utilizando el programa informático ImageJ (http://imagej.nih.gov/ij/).

\subsubsection{Extracción de ARN}

Para la extracción de ARN, se cosecharon los agregados celulares de las placas de 96 pocillos y se transfirieron a microtubos de $1,5 \mathrm{ml}$. Se centrifugaron las muestras durante 5 minutos a $100 \mathrm{xg}$, y se descartaron los sobrenadantes. Los pellets se resuspendieron en $100 \mu \mathrm{l}$ del reactivo Isol-RNA Lysis Reagent (5Prime) y se conservaron a $-80^{\circ} \mathrm{C}$ hasta su 
posterior uso. Al momento de realizar la extracción de ARN, se descongelaron las muestras y se pipetearon para disgregar las células y homogeneizar la mezcla. Posteriormente, se centrifugaron las muestras a $4^{\circ} \mathrm{C}$ durante 10 minutos a $12000 \times$ g. Los sobrenadantes se incubaron durante 5 minutos a temperatura ambiente, y luego se les agregó cloroformo respetando la proporción recomendada por el fabricante de $200 \mu \mathrm{l}$ de cloroformo por cada $1 \mathrm{ml}$ de reactivo Isol-RNA Lysis Reagent utilizado para la lisis. Los tubos se mezclaron por agitación intensa durante 15 segundos y luego se dejaron reposar unos minutos (2-3 minutos) a temperatura ambiente. Luego de centrifugar durante 15 minutos a $12000 \times \mathrm{g}\left(\mathrm{a} 4^{\circ} \mathrm{C}\right.$ ), se separaron las fases acuosas y se transfirieron a nuevos tubos. A ello se añadió isopropanol $(0,5 \mathrm{ml}$ de isopropanol por cada $\mathrm{ml}$ de Isol-RNA Lysis Reagent empleado) y se mezcló exhaustivamente con vortex. Luego de incubar las muestras durante 10 minutos a temperatura ambiente, las mismas se centrifugaron a $12000 \times \mathrm{g}$ durante 10 minutos, a $4^{\circ} \mathrm{C}$. Una vez descartados los sobrenadantes, se agregó etanol $75 \%$ a las muestras (al menos $1 \mathrm{ml}$ por cada $\mathrm{ml}$ del reactivo de lisis empleado). Se centrifugaron las muestras nuevamente, a $7500 \times \mathrm{g}$ durante $5 \mathrm{~min}$, a $4^{\circ} \mathrm{C}$. Una vez eliminados los sobrenadantes, se secaron los pellets de ARN incubándolos 5 minutos a $37^{\circ} \mathrm{C}$, y se los resuspendió en $20 \mu \mathrm{l}$ de agua libre de ribonucleasas (una breve incubación a $65^{\circ} \mathrm{C}$ durante 10 minutos favoreció la disolución).

\subsubsection{Síntesis de cDNA}

Como paso previo a la síntesis de cDNA, se realizó un paso de digestión del ADN. Para ello, se utilizaron $2 \mathrm{U}$ de DNAsa libre de RNAsas (RQ1 RNase-Free DNase, Promega) por $\mu \mathrm{g}$ de ARN. Las mezclas de reacción se incubaron durante 1 hora a $37^{\circ} \mathrm{C}$. Pasado dicho tiempo, la reacción se detuvo mediante el agregado de solución de stop (provista por el fabricante) e incubación a $65^{\circ} \mathrm{C}$ por 10 minutos. Para la síntesis de cDNA se preparó inicialmente una mezcla conteniendo 50pmol de primer oligo-dT, mezcla de dNTPs a concentración final de $1 \mathrm{mM}$ y el ARN molde (no más de $5 \mu \mathrm{g}$ ), todo en un volumen de $10 \mu \mathrm{l}$. Dicha mezcla se calentó a $65^{\circ} \mathrm{C}$ por 5 minutos, y se enfrió inmediatamente en hielo. Seguidamente, se preparó la mezcla de reacción combinando, en un volumen de $20 \mu$ l, la premezcla de molde y primer, 100 unidades de la enzima PrimeScript Reverse Transcriptase (TaKaRa), el buffer y el inhibidor de RNAsas provistos por el fabricante, y agua libre de RNAsas. La reacción se llevó a cabo incubando la mezcla durante 1 hora a $42^{\circ} \mathrm{C}$, seguido de una incubación de 15 minutos a $70^{\circ} \mathrm{C}$ y su inmediato pasaje a hielo. 


\subsubsection{RT-PCR semicuantitativa}

Para los ensayos de RT-PCR semicuantitativa, se realizaron diluciones 1/10, 1/100 y 1/1000 del cDNA molde; y los ciclos de la PCR se limitaron a 30. Para las mezclas de reacción se emplearon dNTPs a una concentración final de $200 \mu \mathrm{M}$ de cada uno de ellos, 1 unidad de Taq polimerasa (New England Biolabs), buffer provisto por el fabricante, y $0,8 \mu \mathrm{M}$ de primers directo e inverso (variando para cada reacción el par de primers de acuerdo a la secuencia que se deseara amplificar) en un volumen final de $25 \mu \mathrm{l}$. Se empleó el gen constitutivo elp (Brehm et al., 2003) a los fines de normalizar los resultados. Los ciclos de temperatura empleados consistieron en una incubación de 2 minutos a $95^{\circ} \mathrm{C}$, seguido de 30 ciclos de incubaciones de 30 segundos a $95^{\circ} \mathrm{C}, 30$ segundos a $50^{\circ} \mathrm{C}\left(045^{\circ} \mathrm{C}\right.$, dependiendo de los primers) y $1 \mathrm{~min}$ a $72^{\circ} \mathrm{C}$, para finalizar con una incubación de 10 minutos a $72^{\circ} \mathrm{C}$. Las secuencias de los primers empleados para la amplificación de los genes de las EmFABPs se encuentran en el Apéndice 7.1.1. Los resultados de las PCR fueron analizados por electroforesis en geles de agarosa al $1 \%$ tal como se describió en el ítem 2.1.1.5, aunque utilizando buffer TAE (40mM Tris-Acetato, $1 \mathrm{mM}$ EDTA, pH 8) en lugar de TBE. Las electroforesis se llevaron a cabo a $100 \mathrm{~V}$ durante 30 minutos, y los geles fueron teñidos con bromuro de etidio para visualizar los fragmentos de ADN.

\subsubsection{Clonado y caracterización in silico de FABPs de E. multilocularis}

\subsubsection{Clonado de las secuencias codificantes de las diferentes EmFABPs}

Para el clonado de las secuencias codificantes de las EmFABPs se partió de cDNA obtenido a partir de agregados de células primarias de E. multilocularis cultivados por dos días en condiciones axénicas en el laboratorio del Dr. Brehm. Dichas células correspondían al aislamiento JAVA. Para la amplificación por PCR de las secuencias buscadas se empleó la polimerasa de alta fidelidad Platinum ${ }^{\circledR}$ Pfx DNA polymerase (Invitrogen), empleando el protocolo descripto en el ítem 2.1.1.3. En los ciclos de amplificación se utilizó la misma configuración descripta en dicho ítem, salvo la temperatura de hibridación que varió de acuerdo a los primers usados en cada caso. La temperatura de hibridación (o annealing) utilizada fue de $45^{\circ} \mathrm{C}$ para las PCR de emfabp4 y de $50^{\circ} \mathrm{C}$ para las demás secuencias. Los productos de PCR se chequearon por electroforesis en geles de agarosa (Ver ítem 2.1.1.5). Para la purificación de los fragmentos amplificados, se sembró la totalidad de las PCR obtenidas en geles de agarosa de $1,2 \%$ y se procedió según lo descripto en el ítem 2.1.1.6. Una vez purificados los fragmentos de PCR, se debió aplicar un protocolo para agregar una 
adenina en el extremo 3' de los mismos (protocolo de A-tailing) para poder clonarlos en el plásmido $p G E M-T$ Easy (Promega), ya que la polimerasa empleada para la amplificación deja los extremos romos. Para ello, se emplearon 5 unidades de Taq DNA Polymerase (Invitrogen), 0,2mM dATP, $1,5 \mathrm{mM} \mathrm{MgCl} 2,5-8 \mu l$ de producto de PCR purificado, el buffer provisto por el fabricante de la enzima, y agua bidestilada estéril, en un volumen final de 10 $\mu$ l. Las mezclas de reacción se incubaron durante 30 minutos a $70^{\circ} \mathrm{C}$. Seguidamente, se realizaron las reacciones de ligación en el vector pGEM-T Easy, el cual se encuentra predigerido y cuenta con nucleótidos de timidina protruyentes capaces de aparearse con las adeninas agregadas a los insertos. Las mezclas de reacción realizadas constaron de $1 \mu \mathrm{l}$ de vector $p G E M-T$ Easy, $5 \mu \mathrm{l}$ de producto de PCR, $1 \mu \mathrm{l}$ de T4 DNA Ligase y el buffer adecuado, provistos por el fabricante del vector. Los tubos con las mezclas de reacción se incubaron a $4^{\circ} \mathrm{C}$ durante toda la noche. Seguidamente, se transformaron bacterias de la cepa E. coli XL-1 Blue siguiendo el protocolo descripto en el ítem 2.1.1.10. La selección de las bacterias transformadas se llevó a cabo empleando placas de medio LB/Agar/Ampicilina (tal como se describió en el ítem 2.1.1.10) a las cuales se les agregó $10 \mu \mathrm{l}$ de IPTG $(400 \mathrm{mM})$ y $10 \mu \mathrm{l}$ de una solución $50 \mathrm{mg} / \mathrm{ml}$ de 5 -bromo4-cloro-3-indolil-beta-D-galacto-piranósido, o X-gal (Promega), para el monitoreo blanco/azul de los clones que contenían inserto ligado al vector. Dicho screening explora la habilidad de las colonias de hidrolizar el compuesto X-gal. Brevemente, en el plásmido pGEM-T Easy el sitio múltiple de clonado se encuentra en medio de una secuencia que codifica un fragmento de la enzima $\beta$-galactosidasa, capaz de complementar al fragmento que es codificado en el genoma de bacterias mutantes, como es el caso de E. coli XL-1 Blue. Si se inserta un fragmento de ADN en el vector, tal que interrumpa dicha secuencia, no puede llevarse a cabo la complementación. De este modo, fenotípicamente, la bacteria carecerá de actividad $\beta$ galactosidasa. Al cultivar las bacterias en placas conteniendo el compuesto X-gal (hidrolizable por la acción de la $\beta$-galactosidasa), se revelan como colonias azules las que tienen actividad $\beta$-galactosidasa (sin inserto en el vector) y como blancas aquellas que tienen un vector recombinante (Sambrook \& Russell, 2001). Se seleccionaron, por lo tanto, colonias blancas, las cuales fueron cultivadas en medio LB líquido para realizar extracciones de ADN plasmídico (Ver ítem 2.1.1.1). Los plásmidos obtenidos se digirieron con la enzima de restricción EcoRI (Ver ítem 2.1.1.4) para luego analizar por electroforesis en geles de agarosa (Ver ítem 2.1.1.5) la presencia de insertos de tamaños correspondientes a lo esperado. Los plásmidos recombinantes se enviaron a secuenciar al servicio de secuenciación de la Unidad de Genómica del Instituto de Biotecnología perteneciente al Instituto Nacional de Tecnología Agropecuaria (INTA). Se empleó el primer universal del promotor SP6. Las secuencias experimentales obtenidas se alinearon con las secuencias predichas empleando la herramienta CLUSTALW del programa bioinformático BioEdit (Ver ítem 7.3.2). 


\subsubsection{Caracterización bioinformática de las secuencias proteicas de las FABPs de E. multilocularis}

Para la caracterización de las secuencias de las FABPs de E. multilocularis se emplearon diversas herramientas bioinformáticas. La búsqueda de dominios característicos de FABPs se llevó a cabo empleando la herramienta bioinformática InterPro (http://www.ebi.ac.uk/interpro/). Los gráficos que representan los resultados obtenidos se realizaron mediante el programa UGENE, disponible en http://ugene.unipro.ru/. La predicción de estructuras secundarias se realizó mediante el programa PSIPRED (http://bioinf.cs.ucl.ac.uk/psipred/). Los alineamientos de secuencia se realizaron empleando la herramienta CLUSTALW, mientras que los porcentajes de similitud de secuencia se calcularon comparando de a pares las secuencias utilizando una herramienta desarrollada para tal fin, ambas del programa BioEdit. La comparación de las EmFABPs con proteínas de otros organismos se realizó empleando la herramienta BLASTP del sitio del NCBI, National Center for Biotechnology Information (http://blast.ncbi.nlm.nih.gov/Blast.cgi).

\subsubsection{Caracterización bioinformática de los genes de las FABPs de $E$. multilocularis}

El análisis de la posición de los intrones en los genes de las EmFABPs se llevó a cabo por comparación de las secuencias codificantes, o CDS (coding DNA sequences), de los distintos genes, con las secuencias genómicas correspondientes empleando la herramienta Splign (http://www.ncbi.nlm.nih.gov/sutils/splign). Las coordenadas de los genes en el genoma de $E$. multilocularis se obtuvieron mediante la herramienta BLASTN del programa BioEdit. La visualización de los genes en el genoma se realizó empleando el programa informático UGENE. Para ello, se contó con la colaboración del Lic. Lucas Maldonado (IMPAM, UBACONICET).

\subsubsection{Predicción de FABPs en E. granulosus y comparación con las FABPs de E. multilocularis}

La búsqueda de los genes ortólogos a las EmFABPs en el genoma de $E$. granulosus se llevó a cabo empleando las herramientas BLAST, tanto de la base de datos GeneDB del Wellcome Trust Sanger Institute (http://www.genedb.org/Homepage) como las del programa BioEdit, comparando con la versión "Egranulosus_genome_v3" del genoma de E. granulosus disponible en ftp://ftp.sanger.ac.uk/pub/project/pathogens/Echinococcus/granulosus/genome. 
Los alineamientos se realizaron también con la herramienta CLUSTALW del programa BioEdit.

\subsubsection{Análisis de la expresión de FABPs en E. multilocularis}

Para realizar estos experimentos se utilizó el protocolo de RT-PCR semicuantitativa descripto en el ítem 2.4.5.5 de la presente sección. Los cDNA utilizados como molde fueron gentilmente cedidos por el Dr. Uriel Koziol (Universidad de Wurzburgo, Alemania). 


\section{RESULTADOS}




\section{RESULTADOS}

\subsection{Subclonado y purificación de EgFABP1}

\subsubsection{Subclonado de EgFABP1}

Durante ensayos de purificación de EgFABP1 recombinante previos a este trabajo, se detectó la presencia de una proteína de aproximadamente $30 \mathrm{kDa}$ que resultaba difícil de separar de EgFABP1. Asimismo, se notó que el nivel de expresión de dicha proteína era bastante alto y que respondía a la inducción con IPTG, por lo que se concluyó que podía ser la $\beta$-lactamasa codificada por el vector $\mathrm{pET}-5 a$ en el que se encontraba clonada la región codificante del gen de EgFABP1 (Ver Apéndice 7.2).

Con la finalidad de intentar subsanar dichos inconvenientes, se decidió subclonar la región codificante para EgFABP1 en el vector de expresión pET-11b. Dicho vector cuenta con un terminador de la transcripción proveniente del fago T7 (río abajo del sitio de clonado) que evita que la RNA polimerasa genere transcriptos que incluyan, junto al mensajero de interés, la secuencia codificante de la $\beta$-lactamasa. Por otro lado, el vector pET-11b también codifica para el represor Lacl, y cuenta con un operador lac entre el promotor del fago T7 y el sitio de clonado (Ver Apéndice 7.2). De este modo, se puede obtener una expresión más regulada de la proteína recombinante clonada en dicho vector, ya que en ausencia de IPTG el represor Lacl se encuentra unido al operador lac y evita la transcripción del gen de interés. Esto es importante para reducir las posibilidades de que la expresión basal de la proteína recombinante pueda dificultar el crecimiento del cultivo bacteriano.

Para llevar a cabo el subclonado de la región codificante del gen egfabp1, se realizó una PCR con primers específicos para dicha secuencia (Ver ítem 2.1.1.3 de la sección Materiales y Métodos) utilizando como molde el plásmido pET-5a-egfabp1 generado en el laboratorio de la Dra. Esteves (UdelaR, Montevideo, Uruguay). Por otra parte, se transformaron bacterias de la cepa E. coli XL1-Blue con el plásmido pET-11b (Ver ítem 2.1.1.10 de Materiales y Métodos) para amplificarlo y luego extraerlo siguiendo los protocolos descriptos en el ítem 2.1.1.1 de la sección Materiales y Métodos. Ambas moléculas de ADN (fragmento amplificado por PCR y vector) fueron digeridas con las enzimas de restricción $\mathrm{Ndel}$ y $\mathrm{BamHI}$, tal como se describió previamente. Las muestras digeridas con las enzimas de restricción se sometieron a electroforesis en geles de agarosa (Figura $R$-1) y se purificaron los fragmentos de interés siguiendo los protocolos descriptos en la sección de Materiales y Métodos. 


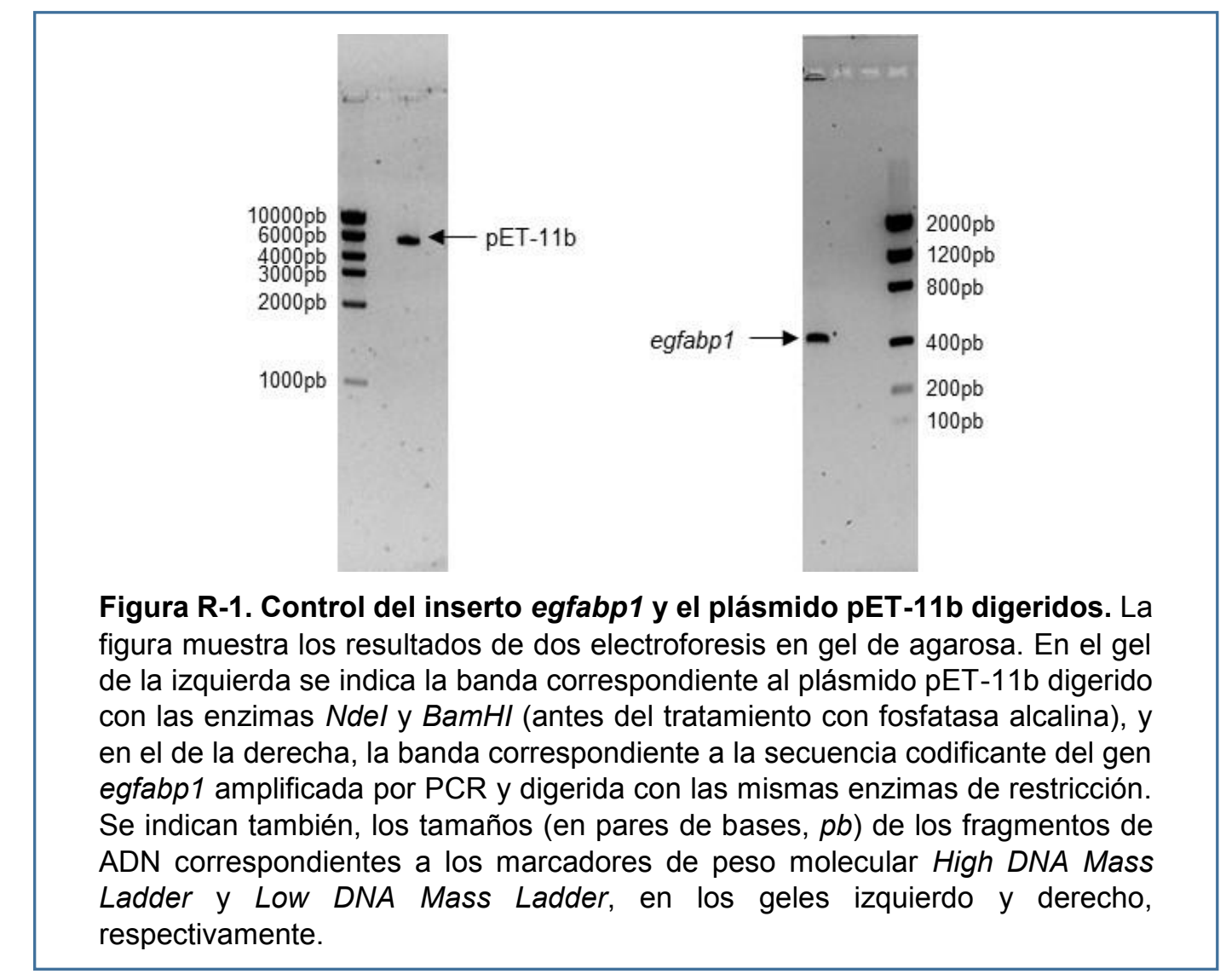

El vector $\mathrm{pET}-11 \mathrm{~b}$ digerido fue desfosforilado, mediante tratamiento con fosfatasa alcalina, para evitar la religación del mismo. Las ligaciones se realizaron en presencia de un exceso de inserto. Posteriormente, se transformaron bacterias competentes de la cepa E. coli XL1-Blue con la mezcla de ligación y se cultivaron en placas de LB/Agar/Ampicilina. Para determinar las colonias transformadas con el vector conteniendo el inserto se aplicó la técnica de PCR según lo descripto en el ítem 2.1.1.10 de la sección Materiales y Métodos. Se encontraron dos colonias que dieron resultados positivos por PCR (Figura R-2), las cuales se cultivaron en mayor escala para aislar el plásmido y para generar stocks de glicerol que fueron almacenados a $-80^{\circ} \mathrm{C}$. Una muestra de cada uno de los plásmidos obtenidos a partir de las colonias positivas se digirió con $\mathrm{Ndel}$ y $\mathrm{BamHl}$, y se sometió a electroforesis en gel de agarosa para rechequear que el tamaño del inserto clonado fuera el adecuado, es decir, 402pb (Figura $R$-3). Finalmente, los plásmidos obtenidos se secuenciaron mediante el servicio de secuenciado de la empresa Macrogen Inc., empleando para ello los primers específicos EgFABP1-Fw y EgFABP1-Rv (Ver Apéndice 7.1.1). Los resultados del secuenciado se encuentran en el Apéndice 7.3.1. 


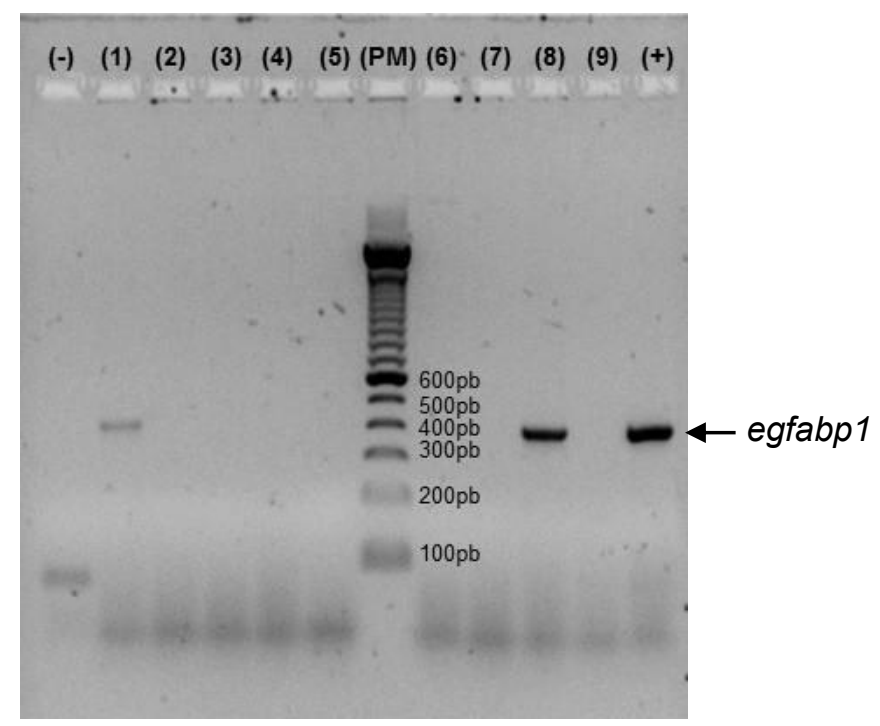

Figura R-2. Screening por PCR de bacterias transformadas con plásmidos recombinantes. La figura corresponde a un gel de agarosa con el resultado de las reacciones de PCR utilizadas para analizar la presencia de la secuencia codificante de egfabp1 en los plásmidos presentes en las bacterias E. coli XL1-Blue transformadas con la ligación. La calle (-) corresponde a un control negativo (sin ADN molde), la calle (+) es un control positivo (utilizando el plásmido pET-5aegfabp1 como molde), las calles (1) a (9) corresponden a las distintas colonias evaluadas, mientras que la calle (PM) contiene el marcador de peso molecular 100bp DNA Ladder.

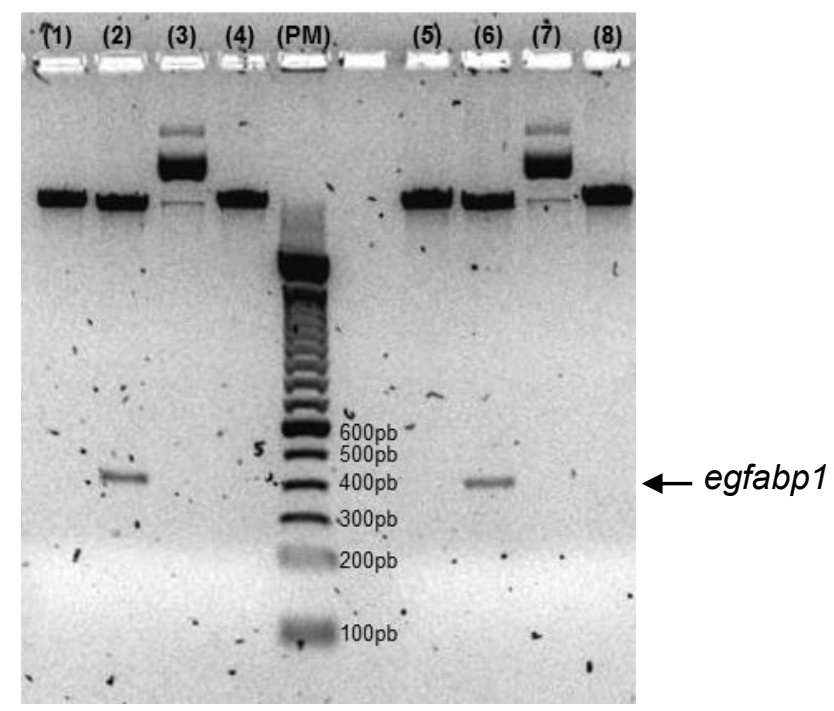

Figura R-3. Chequeo de los plásmidos recombinantes por digestión con enzimas de restricción. La figura muestra el resultado de la digestión con enzimas de restricción de los plásmidos extraídos de las colonias 1 y 8 que dieron positivas para el gen egfabp1 en la prueba por PCR. Las calles a la izquierda del marcador de peso molecular (PM) corresponden a muestras de la colonia 1, mientras que las que se encuentran a la derecha corresponden a la 8. Las calles (1) y (5) contienen muestras digeridas solo con $\mathrm{BamHl}$; las calles (2) y (6), muestras digeridas con $\mathrm{BamHI}$ y Ndel; en las calles (3) y (7) hay muestras de plásmidos sin digerir; y en la (4) y (8), las muestras digeridas sólo con Ndel. Se indica el tamaño (en pb) de las bandas del marcador de peso molecular y la posición del inserto egfabp1. 


\subsubsection{Purificación de EgFABP1}

Una vez confirmada la secuencia del inserto egfabp1 en el plásmido pET-11b, se procedió a transformar bacterias de la cepa E. coli BL21(DE3) con la construcción obtenida, empleando los protocolos descriptos previamente. Una vez seleccionadas las bacterias transformadas, se procedió a realizar un ensayo de screening de expresión de proteínas siguiendo el protocolo descripto en el ítem 2.1.2.1 de la sección Materiales y Métodos. En dicho experimento se analizaron tanto cultivos bacterianos conteniendo el plásmido pET-11begfabp1, como cultivos de E. coli BL21(DE3) conteniendo el plásmido original pET-5aegfabp1. En ambos casos, se comparó la expresión de proteínas antes y después de la inducción con 400 $\mu \mathrm{M}$ IPTG mediante electroforesis desnaturalizante en geles de poliacrilamida, o SDS-PAGE (Ver figura $R-4$ ).

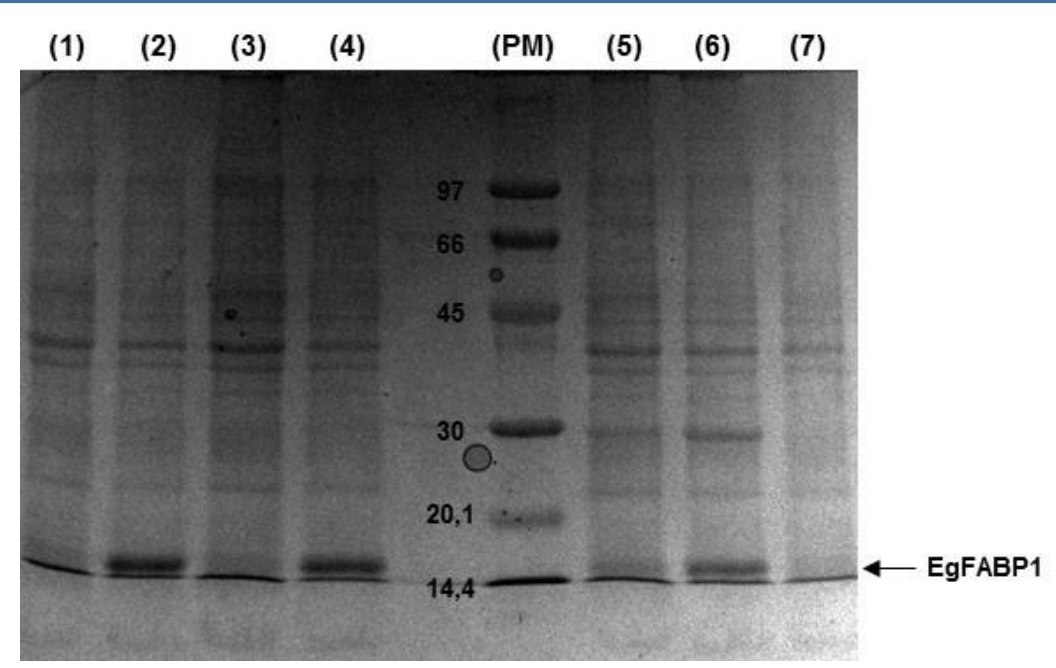

Figura R-4. Screening de expresión de EgFABP1. Las calles (1) a (4) corresponden a extractos proteicos de bacterias E. coli BL21(DE3) transformadas con el plásmido pET-11b-egfabp1. Las proteínas sembradas en las calles (5) y (6) provienen de cultivos bacterianos de E. coli BL21(DE3) conteniendo el plásmido pET-5a-egfabp1. La calle (7), por su parte, corresponde a un cultivo de la misma cepa bacteriana, pero portadora del plásmido pET-11b sin inserto. Las calles (2),

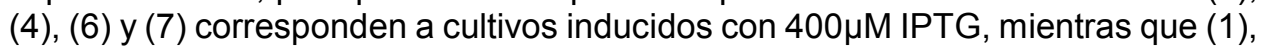
(3) y (5), a cultivos sin inducir. A la izquierda de las bandas del marcador de peso molecular se indica el peso molecular de las mismas en kDa.

Tal como se puede apreciar en la Figura $R-4$, las bacterias E. coli BL21(DE3) transformadas con el plásmido $\mathrm{pET}$-11b-egfabp1 fueron capaces de expresar EgFABP1 luego de la inducción con IPTG. Al analizar los patrones de expresión proteica producidos por las bacterias empleadas en el ensayo, se puede observar que en aquellas que portan el plásmido $\mathrm{pET}-11 \mathrm{~b}$ egfabp1 existen niveles menores de expresión de una proteína de alrededor de 30kDa, si se lo compara con los extractos provenientes de bacterias que llevan el plásmido pET-5a- 
egfabp1. Dicha proteína, tal como se mencionó previamente, resultaba ser un contaminante difícil de remover en los ensayos previos de purificación de EgFABP1.

Una vez determinada la capacidad de las bacterias de producir la proteína EgFABP1 recombinante, se procedió con su expresión a mayor escala y con su purificación. A continuación se presentan, a modo de ejemplo, los pasos de una purificación de EgFABP1.

Luego del cultivo, inducción y lisado de las bacterias, se ultracentrifugaron las muestras y se conservó el sobrenadante. A dicha muestra se le realizó un proceso de precipitación con $\left(\mathrm{NH}_{4}\right)_{2} \mathrm{SO}_{4}$, o Salting Out, que permitió remover parte de las proteínas contaminantes (Ver Figura $R-5)$.

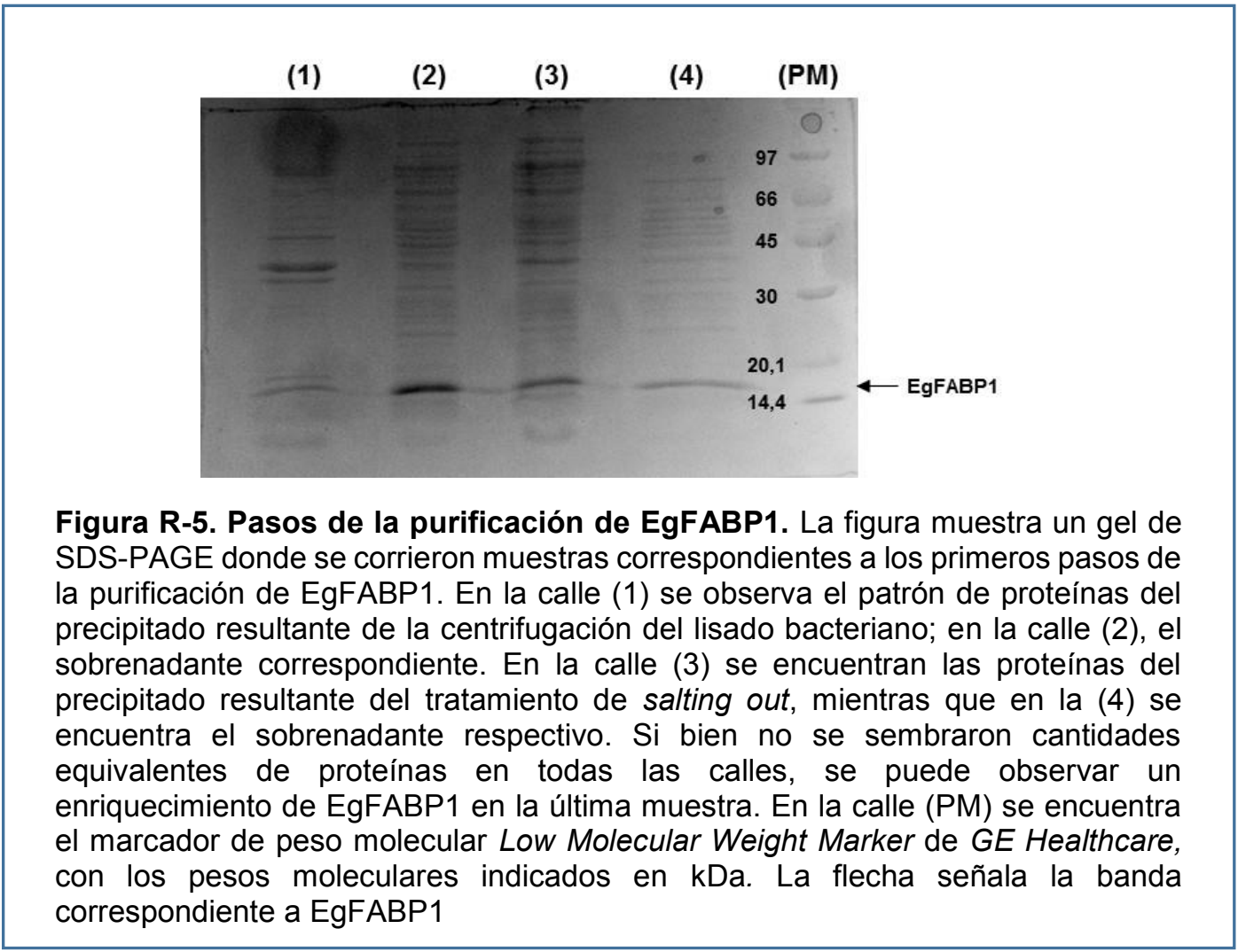

Seguidamente, se concentró la muestra, se incubó la mezcla de proteínas con ácido palmítico marcado con ${ }^{14} \mathrm{C}$, y se realizó una cromatografía de exclusión molecular. Las muestras eluídas de la columna de exclusión molecular se analizaron por medida de absorbancia a $280 \mathrm{~nm}$, medida de la radiactividad y por SDS-PAGE (Ver Figuras $R-6$ y R-7). Una vez identificados los tubos que contenían EgFABP1, se reunieron todas las muestras, se concentraron y se cambiaron de buffer para proceder a la deslipidización de la proteína (ver detalles en la sección Materiales y Métodos). La modificación del buffer empleado para la deslipidización, respecto al empleado en los protocolos tradicionales de purificación de las FABPs (Hsu \& Storch, 1996) fue necesaria debido a que los mismos no resultaban satisfactorios para la remoción exhaustiva de los ácidos grasos que copurificaban unidos a 
EgFABP1. Las nuevas condiciones de deslipidización se establecieron en base a datos bibliográficos que proponían la utilización de buffers de alta fuerza iónica durante los pasos de deslipidización de proteínas capaces de unir ligandos hidrofóbicos, con el objetivo de aumentar la interacción de los lípidos con las resinas hidrofóbicas empleadas para dichos fines (Velkov et al., 2008).

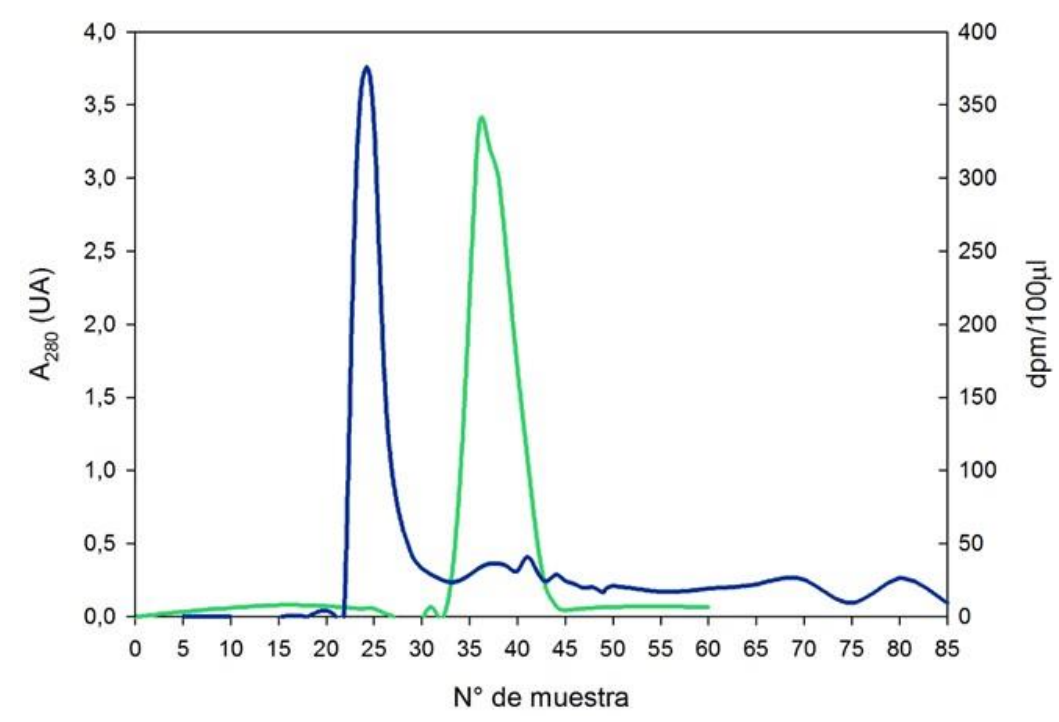

Figura R-6. Cromatograma correspondiente a la cromatografía de exclusión molecular. La línea azul corresponde a la absorbancia medida a $280 \mathrm{~nm}$, mientras que la verde representa las $\mathrm{dpm} / 100 \mu \mathrm{l}$ presentes en las muestras. La radiactividad correspondiente al $\left[1-{ }^{14} \mathrm{C}\right]$-Palmitato se concentra en las muestras en las que eluye EgFABP1.

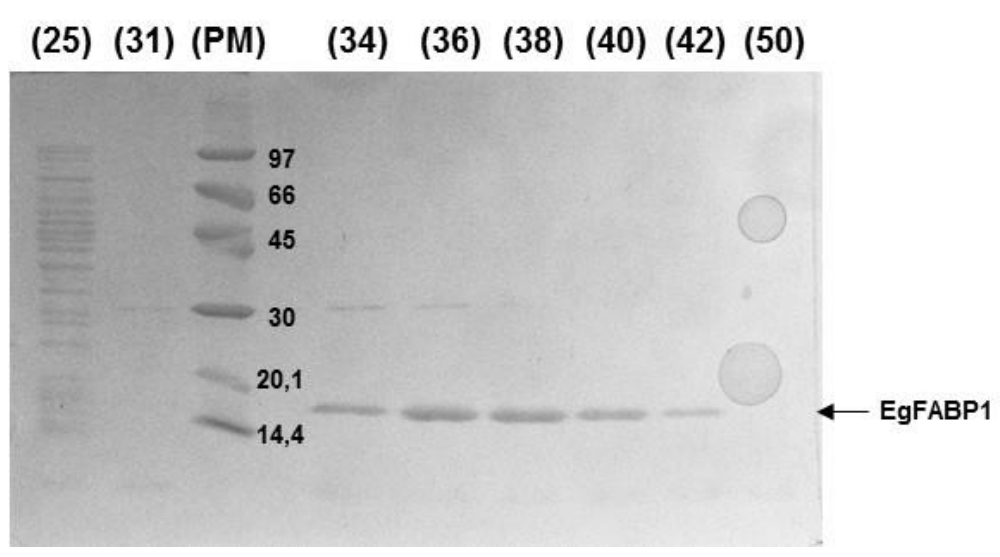

Figura R-7. SDS-PAGE de las muestras colectadas de la cromatografía de exclusión molecular. La figura muestra un gel de SDS-PAGE teñido con Coomassie en donde se observan los perfiles de proteínas de las fracciones eluídas de la cromatografía de exclusión molecular. Los números que se encuentran por encima de las calles indican el número de tubo correspondiente a cada muestra. La flecha señala la banda correspondiente a EgFABP1. 
Luego del cambio de buffer, se inyectó la muestra en una columna con resina Lipidex 1000 termostatizada a $37^{\circ} \mathrm{C}$ y equilibrada en el mismo buffer con alta concentración de sales. La proteína eluyó como un único pico (Figura $R-8$ ) sin haber sido retenida en la columna.

Tal como se mencionó previamente, se tomaron muestras antes y después del tratamiento con Lipidex 1000 para medirles la radiactividad.

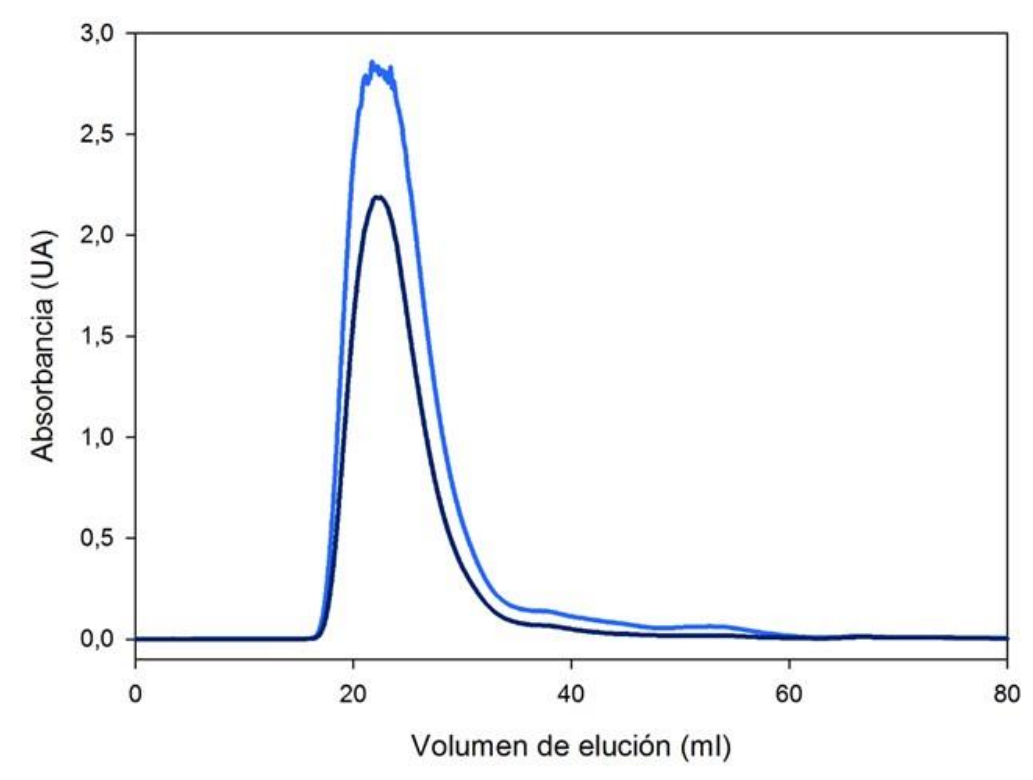

Figura R-8. Cromatograma correspondiente a la cromatografía de interacción hidrofóbica. La línea azul corresponde a la absorbancia medida a $280 \mathrm{~nm}$, mientras que la celeste representa la absorbancia a $260 \mathrm{~nm}$.

Dado que la contaminación con ácidos nucleicos imposibilitó la medición precisa de la concentración de EgFABP1 por absorbancia a $280 \mathrm{~nm}$, se asumió que toda la proteína que ingresó a la columna de interacción hidrofóbica fue la misma que se colectó luego de su pasaje por dicha resina. De este modo, luego de realizada la medida de radiactividad, se corrigieron las mismas por el valor obtenido para el blanco y se observó que la remoción de marca radiactiva había resultado eficiente (Ver Tabla $R-1)$.

\begin{tabular}{|c|c|}
\hline Muestra & Radiactividad total (dpm) \\
\hline $\begin{array}{c}\text { Antes del tratamiento con } \\
\text { Lipidex 1000 }\end{array}$ & 241,11 \\
\hline $\begin{array}{c}\text { Después del tratamiento } \\
\text { con Lipidex 1000 }\end{array}$ & 0,44 \\
\hline
\end{tabular}

Tabla R-1. Deslipidización de EgFABP1. La tabla muestra los valores obtenidos para la medida de radiactividad de las muestras antes y después del tratamiento con Lipidex 1000 
Asimismo, una muestra de la proteína eluída de la columna de interacción hidrofóbica fue chequeada por SDS-PAGE. En la Figura R-9 se puede observar el gel teñido con azul de Coomassie en donde la banda correspondiente a EgFABP1 es claramente la mayoritaria.

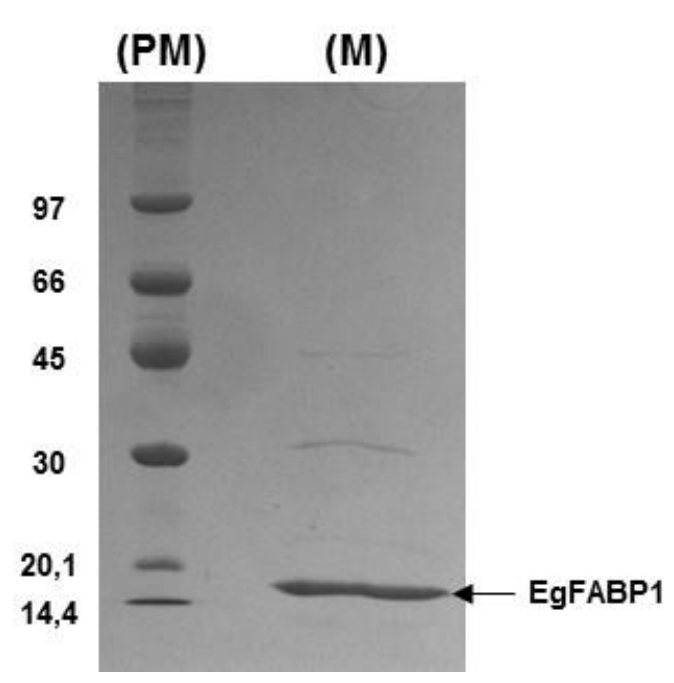

Figura R-9. SDS-PAGE de la muestra obtenida luego de la cromatografía de interacción hidrofóbica. En la figura se observa un gel de SDS-PAGE conteniendo una muestra (M) de EgFABP1 luego del tratamiento con Lipidex 1000. A la izquierda se encuentra el marcador de peso molecular (PM) con el peso correspondiente a cada banda indicado en $\mathrm{kDa}$. La flecha indica la banda correspondiente a EgFABP1.

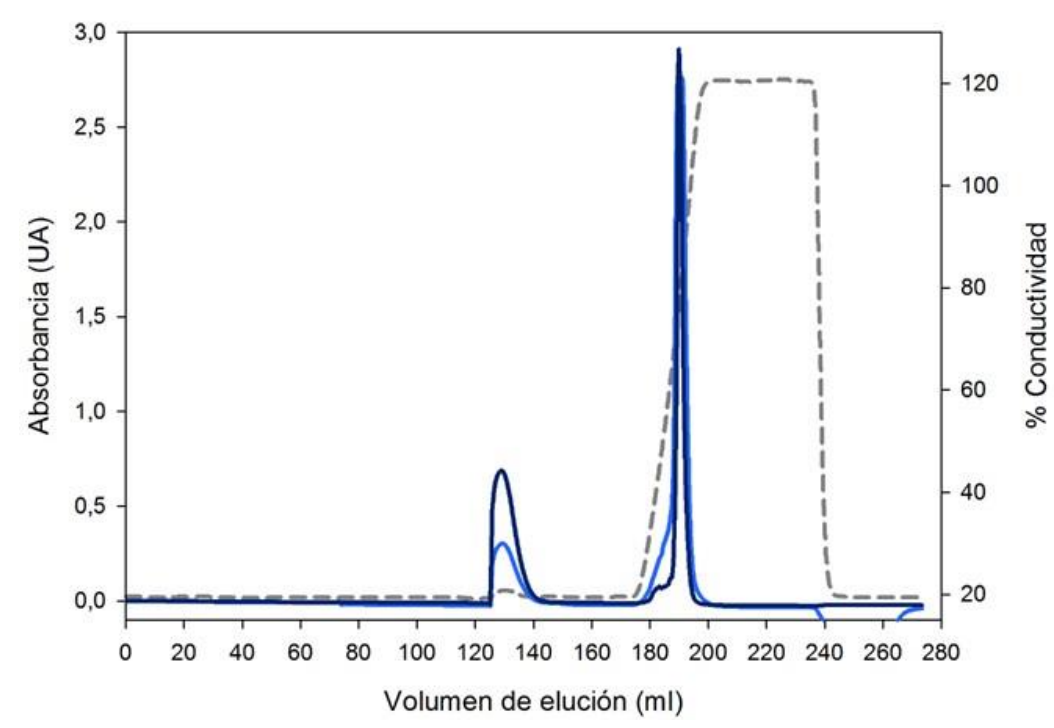

Figura R-10. Cromatograma correspondiente a la cromatografía de intercambio iónico. La línea azul oscura corresponde a la absorbancia medida a $280 \mathrm{~nm}$, mientras que la celeste representa la absorbancia a $260 \mathrm{~nm}$. La línea punteada gris simboliza el gradiente de elución $150 \mathrm{mM}-1 \mathrm{M} \mathrm{KCl}$. 
Debido a la presencia de ácidos nucleicos en la muestra de proteína, luego del proceso de deslipidización se concentró la proteína y se le cambió el buffer, para volverla al buffer original de menor fuerza iónica. Posteriormente, la proteína fue inyectada en una columna de intercambio aniónico (MonoQ) equilibrada en el mismo buffer. La resina había sido previamente lavada con el buffer de alta fuerza iónica. Dado que al pH de esa solución la proteína EgFABP1 tiene una carga ligeramente positiva, la misma no fue retenida por la resina. Sin embargo, los ácidos nucleicos contaminantes quedaron atrapados en la resina y fueron eluídos posteriormente aumentando la fuerza iónica del buffer de elución (Ver Figura $R-10)$.

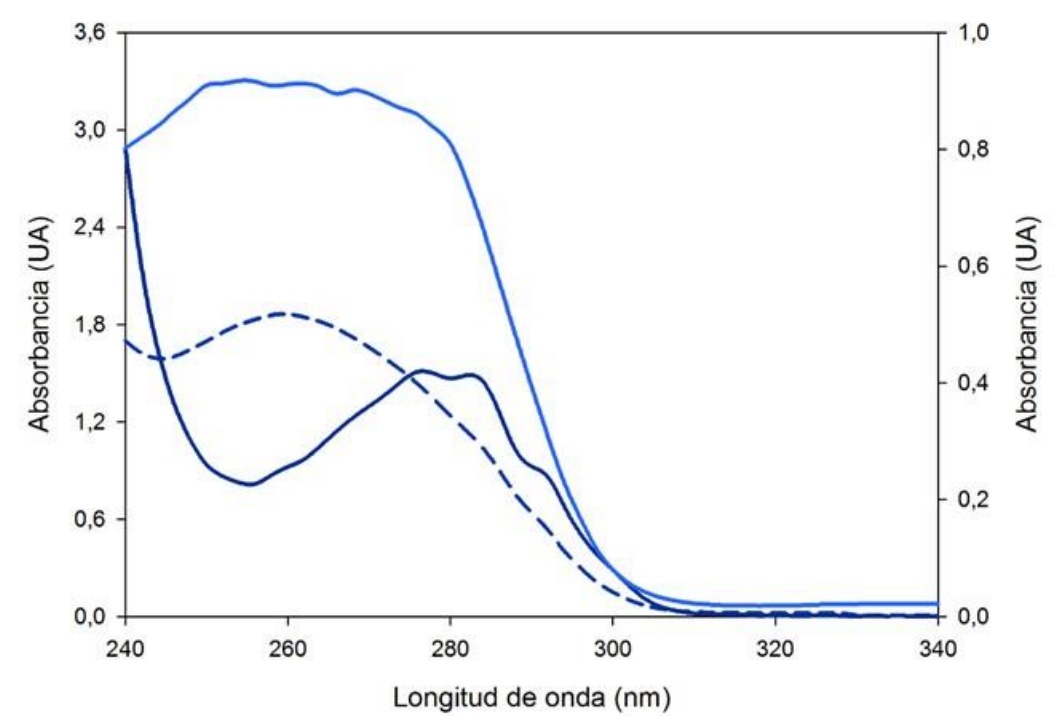

Figura R-11. Espectros de absorción de diferentes muestras de EgFABP1. En línea punteada se muestra el espectro de absorción de la muestra que se inyectó en la columna de intercambio iónico (conteniendo tanto EgFABP1 como ácidos nucleicos). La línea de color azul oscuro muestra el espectro de absorción de EgFABP1 luego de la remoción de los ácidos nucleicos, mientras que la línea celeste corresponde al espectro de los ácidos nucleicos eluídos de la columna de intercambio iónico. Los valores de absorbancia del eje de la derecha corresponden al espectro de EgFABP1.

Las muestras conteniendo EgFABP1 obtenidas luego del pasaje por la columna de intercambio iónico fueron colectadas y concentradas empleando dispositivos tipo Vivaspin. Se tomaron espectros de absorción de la muestra que se tenía antes de la cromatografía de intercambio iónico, y de las fracciones de EgFABP1 y de ácidos nucleicos obtenidas luego. En la Figura $R-11$ se puede observar claramente cómo cambia el espectro de absorción de la muestra luego del tratamiento. El espectro de absorción de la muestra de EgFABP1 libre de ácidos nucleicos presenta un espectro característico de una proteína, presentando un máximo a $280 \mathrm{~nm}$, con una caída de la absorbancia hacia los $260 \mathrm{~nm}$. Cabe mencionar que si bien las concentraciones de las diferentes muestras no son comparables, lo más destacable es la 
variación a nivel cualitativo de los espectros. La proteína obtenida de este modo, fue alicuotada en microtubos y se conservó a $-80^{\circ} \mathrm{C}$ para su posterior uso.

\subsubsection{Control de la integridad estructural de EgFABP1}

Una vez establecido el protocolo de purificación de EgFABP1, se realizaron una serie de pruebas con la finalidad de determinar el estado de agregación y el plegamiento de la proteína.

En primer lugar, se llevó a cabo un análisis por cromatografía de exclusión molecular, para lo cual se utilizaron tres proteínas de peso molecular conocido como estándares: BSA, cuyo peso molecular es de 66kDa; anhidrasa carbónica (AC), de 29kDa; e I-FABP, de 15,1kDa. Se realizaron dos inyecciones de EgFABP1. En ambos casos EgFABP1 eluyó como un único pico en el mismo volumen de elución, el cual prácticamente coincidió con el de IFABP. El peso molecular aparente calculado para EgFABP1 fue de 15,6kDa, lo cual es concordante con su peso molecular teórico de $15 \mathrm{kDa}$; indicando, por lo tanto, que la proteína se encontraba en forma monomérica (Ver Figura R-12).

Por otra parte, se realizaron también medidas de dicroísmo circular para analizar el plegamiento de la proteína purificada. Esta técnica es capaz de brindar información sobre el contenido global de estructura secundaria de las proteínas, cuando se analizan sus espectros en el UV lejano; así como sobre la estructura terciaria de las mismas, cuando se analizan los espectros en el UV cercano (Córsico et al., 2013). Para EgFABP1 se realizaron medidas tanto en el UV lejano como en el UV cercano (Ver detalles en la sección Materiales y métodos, ítem 2.1.3.2), empleando la proteína I-FABP (purificada en nuestro laboratorio) como control para el caso de los espectros en el UV lejano. I-FABP es, al igual que EgFABP1, una proteína formada por un barril $\beta$ coronado por dos hélices $\alpha$. Tal como se puede observar en el Panel $A$ de la Figura $R-13$, el espectro de dicroísmo circular de EgFABP1 en el UV lejano presentó una importante similitud con el espectro de I-FABP, destacándose un único mínimo alrededor de los $215 \mathrm{~nm}$, lo cual es característico de proteínas con un alto contenido de hoja $\beta$ (Córsico et al., 2013).

Por su parte, el espectro de dicroísmo circular de EgFABP1 en el UV cercano (Figura R13, Panel B) presentó picos bien definidos, lo cual es indicativo de que la proteína poseía una estructura terciaria definida. 

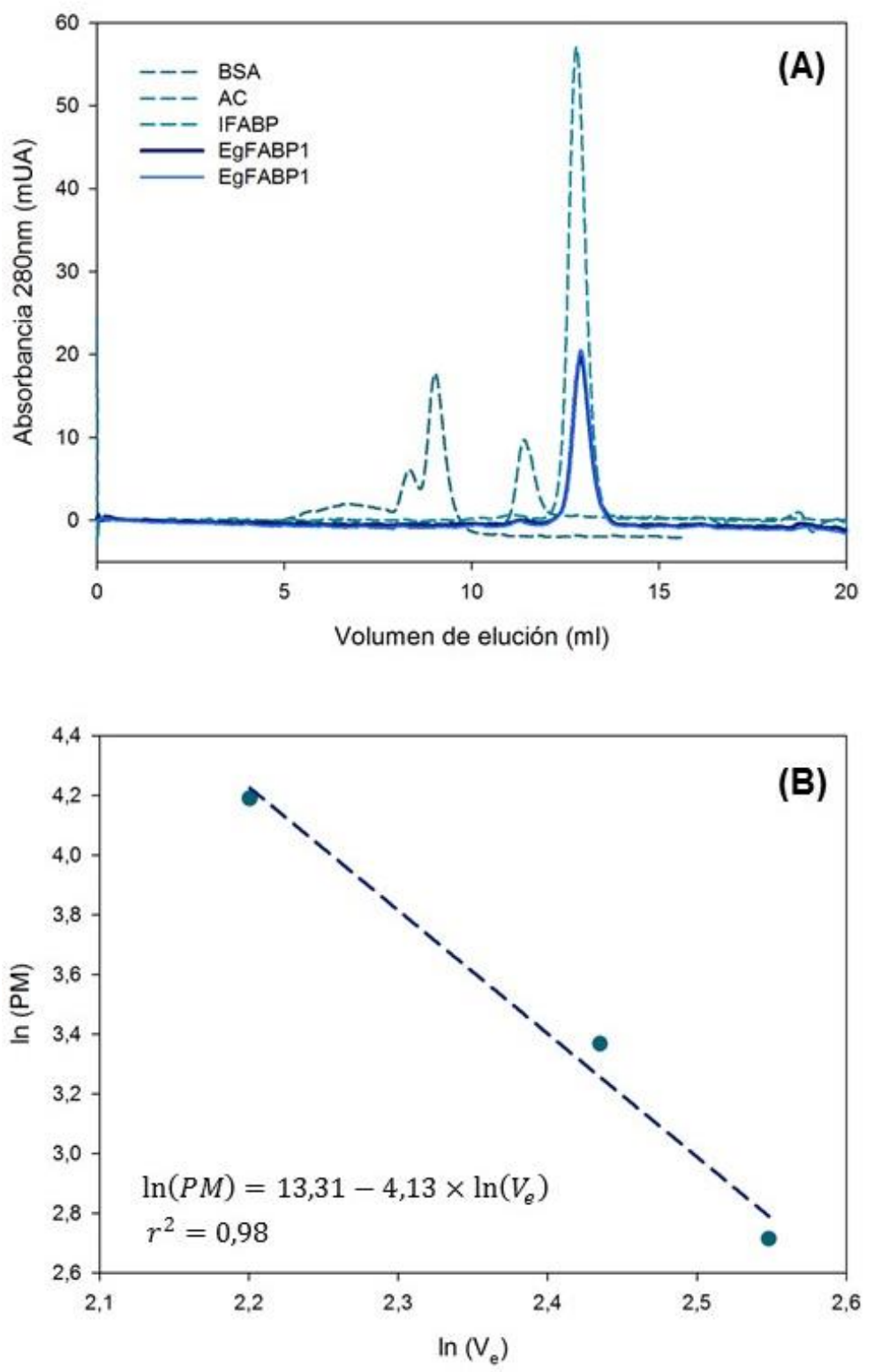

Figura R-12. Análisis por cromatografía de exclusión molecular de EgFABP1 purificada. En el panel (A) se observan los cromatogramas correspondientes a la elución de las diferentes proteínas patrón (líneas punteadas) y de EgFABP1 (líneas completas). En el panel (B) se muestra la curva de calibración correspondiente, así como la ecuación correspondiente al ajuste lineal. 

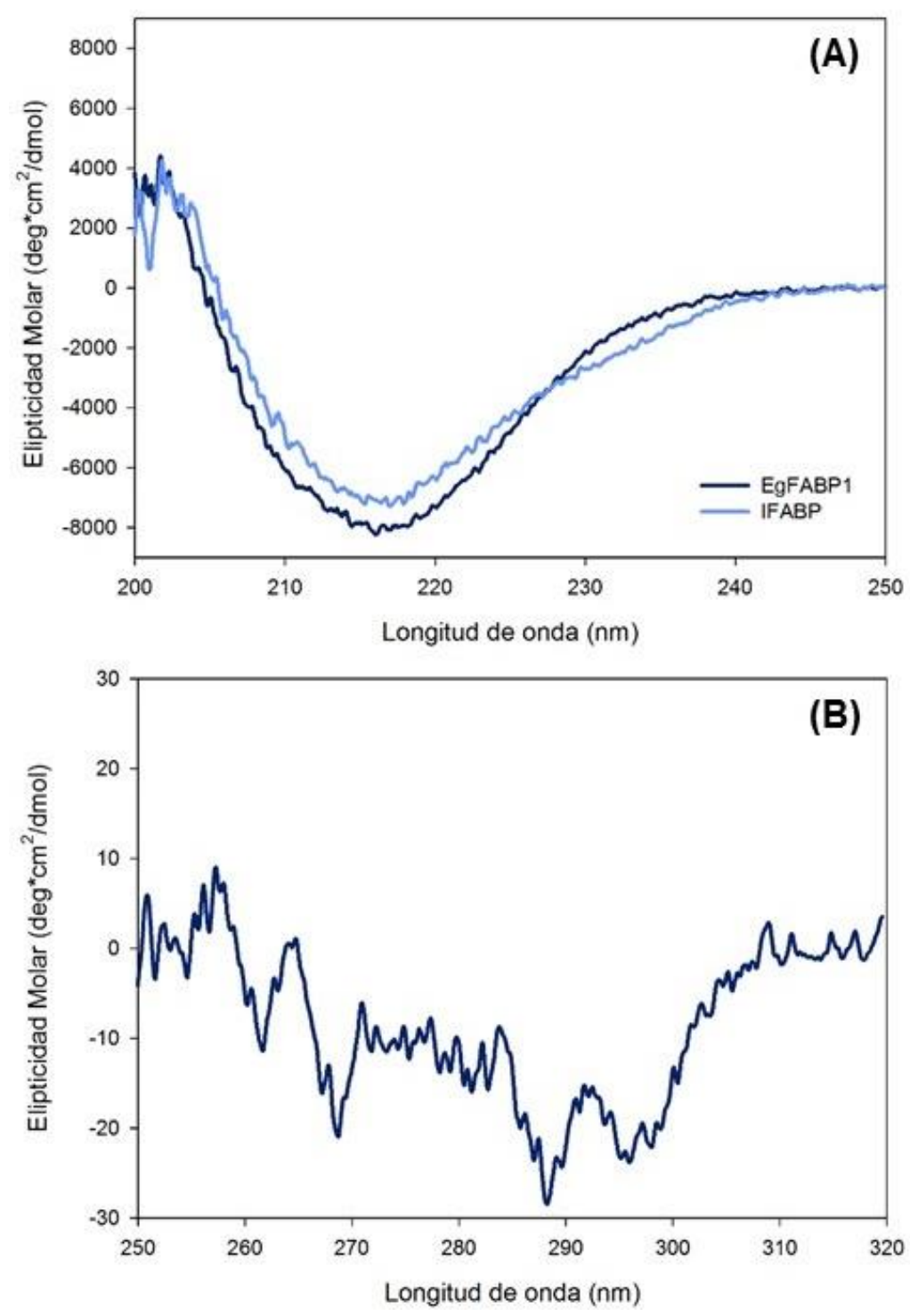

Figura R-13. Espectros de dicroísmo circular de EgFABP1. En el panel (A) se observan los espectros de dicroísmo circular en el UV lejano de EgFABP1 (línea azul) y de IFABP (línea celeste). El panel (B) muestra el espectro en el UV cercano correspondiente a EgFABP1.

\subsection{Análisis de la interacción de EgFABP1 con ligandos}

\subsubsection{Análisis de lípidos de Escherichia coli unidos a EgFABP1 recombinante}

Uno de los enfoques encarados en el estudio de la interacción de EgFABP1 con ligandos consistió en analizar cuáles eran los lípidos que copurificaban unidos a EgFABP1 cuando dicha proteína era purificada a partir de $E$. coli. Si bien el citoplasma de E. coli no es el entorno natural de la proteína, este enfoque podría contribuir a determinar qué tipo de compuestos 
une preferentemente EgFABP1 dentro de una gama compleja de compuestos hidrofóbicos presentes en el citoplasma bacteriano. Para ello, se sobre-expresó EgFABP1 en E. coli y se purificó la proteína tal como se describió previamente, pero sin el paso de deslipidización. Posteriormente, se extrajeron los lípidos con solventes orgánicos y se analizó una muestra de lo extraído por TLC (Ver ítem 2.2.1 de la sección Materiales y métodos). Se observó que la muestra contenía únicamente ácidos grasos libres (Ver Figura R-14). Seguidamente, se identificaron dichos ácidos grasos mediante cromatografía gaseosa (Ver Materiales y Métodos).
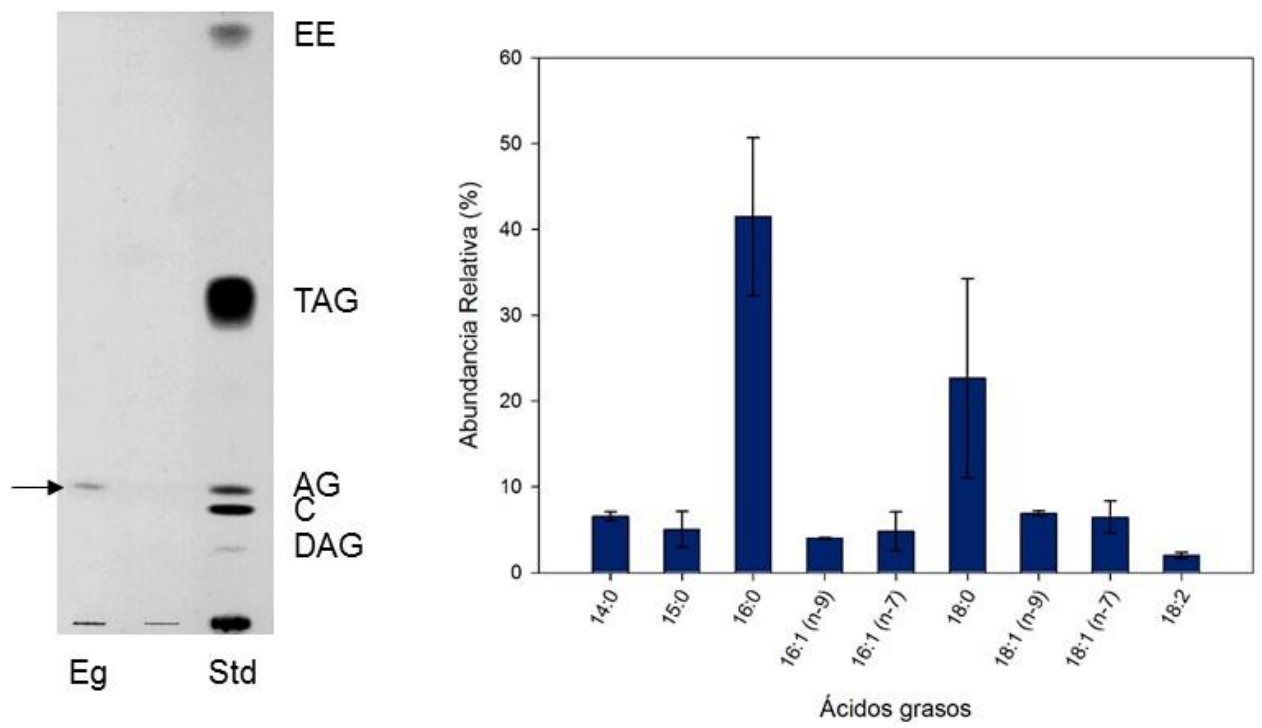

Figura R-14. Análisis de lípidos de E. coli unidos a EgFABP1 recombinante. En la figura, a la izquierda, se muestra una foto de la placa de TLC de lípidos neutros donde se sembraron los lípidos extraídos de EgFABP1 $(\mathrm{Eg})$ y un estándar correspondiente a lípidos de hígado de rata (Std). A la derecha del estándar se indica a qué corresponden las bandas que se observan: diacilgliceroles (DAG), colesterol (C), ácidos grasos libres (AG), triacilgliceroles (TAG) y ésteres de esteroles (EE). La flecha indica la banda correspondiente a $A G$ en la muestra extraída de EgFABP1. El gráfico de la derecha muestra los $A G$ detectados por $\mathrm{GC}$ en la muestra de lípidos extraídos de EgFABP1 recombinante: ácido mirístico (14:0), pentadecanoico (15:0), palmítico (16:0), 7hexadecenoico (16:1 n-9), palmitoleico (16:1 n-7), esteárico (18:0), oleico (18:1 n-9), vaccénico (18:1 n-7) y linoleico (18:2). Se muestran los promedios de dos experimentos, con sus desvíos estándar.

Tal como se observa en la Figura R-14 (panel de la derecha), EgFABP1 es capaz de unir una variedad más o menos amplia de ácidos grasos presentes en el citoplasma de $E$. coli, siendo los mayoritarios el ácido palmítico (16:0) y el ácido esteárico (18:0), aunque también se detectan otros ácidos grasos de diferente longitud de cadena y grado de insaturación. Cabe aclarar que el ácido linoleico (18:2) detectado debe provenir del medio de cultivo, ya que $E$. coli es incapaz de sintetizar ácidos grasos poliinsaturados (Cronan \& Rock, 1994; Lowe et al., 1987). No es sorprendente que el ácido palmítico sea el principal ácido graso unido a EgFABP1 recombinante, ya que ha sido reportado como el posible ligando determinado en la 
estructura cristalográfica de esta proteína (Jakobsson et al., 2003). Asimismo, varios de los ligandos detectados por esta metodología han sido propuestos como ligandos de EgFABP1 en estudios previos de unión in vitro (Alvite et al., 2001).

\subsubsection{Análisis de la interacción con ligandos por proteólisis parcial de EgFABP1}

Con la finalidad de analizar la interacción de EgFABP1 con ácidos grasos desde otro punto de vista, se realizaron experimentos de proteólisis parcial de la proteína en su forma apo- y complejada con diferentes ligandos. Esta técnica brinda información en relación a cambios conformacionales producidos en proteínas ya que permite detectar regiones con alta flexibilidad, sitios más o menos expuestos a las proteasas, y cómo éstos se alteran al interactuar la proteína con un ligando (Arighi et al., 2003; Fontana et al., 2004; Hubbard, 1998).

Para llevar a cabo este análisis, se incubó la proteína EgFABP1 recombinante, en su forma libre de ligandos (apo) o unida a diferentes ácidos grasos, con la enzima proteolítica ArgC (también llamada Clostripaína), que es capaz de hidrolizar enlaces peptídicos en los que esté involucrado el grupo carboxilo de residuos de Arginina. Las digestiones se llevaron a cabo a diferentes tiempos, y los productos resultantes se separaron por SDS-PAGE en geles de tricina (Para más detalles, ver ítem 2.2.2 de la sección Materiales y Métodos).

Tal como se observa en la Figura R-15, la unión de ligandos a EgFABP1 le brinda a la proteína una cierta "protección" frente al ataque proteolítico por ArgC. En el panel A de la Figura $R-15$ se puede observar claramente que al incubar a EgFABP1 en su forma apo con ArgC durante 5 minutos se obtienen numerosos, y diversos, fragmentos proteolíticos; mientras que la EgFABP1 complejada con diversos ácidos grasos sufre una proteólisis mucho menor, siendo mayoritaria la banda correspondiente a la proteína entera. Asimismo, es posible notar que el complejo EgFABP1-ácido oleico genera un patrón de digestión ligeramente diferente a los demás (al menos en cuanto a la proporción relativa de los fragmentos generados). En el panel $B$, por su parte, se observa que EgFABP1 en su forma apo, es digerida casi por completo luego de 16 horas de incubación con la endoproteasa ArgC. Por otro lado, las muestras de EgFABP1 en presencia de ligandos mostraron una resistencia importante a la degradación, manteniendo una buena proporción de proteína sin digerir aún luego de 16 horas de incubación con la proteasa. La digestión de EgFABP1 unida a ácido oleico muestra la presencia de fragmentos diferentes a los presentes en los demás complejos proteína-ligando.

Esto puede ser interpretado de diferentes maneras: por un lado, se puede pensar que la unión de ácido oleico a EgFABP1 induciría cambios conformacionales sobre la proteína que generarían una mayor exposición de los sitios blancos de la acción de la proteasa (residuos de arginina en el caso de $\mathrm{ArgC}$ ) y por ende, se cortaría un mayor número de enlaces que en los otros casos. Otra posible interpretación radica en el hecho de que EgFABP1 podría adoptar 
una estructura menos rígida en presencia de ácido oleico, comparada a sus formas unidas a otros ácidos grasos, haciendo que determinadas regiones posean mayor movilidad y por lo tanto, puedan ser atacadas por la proteasa.

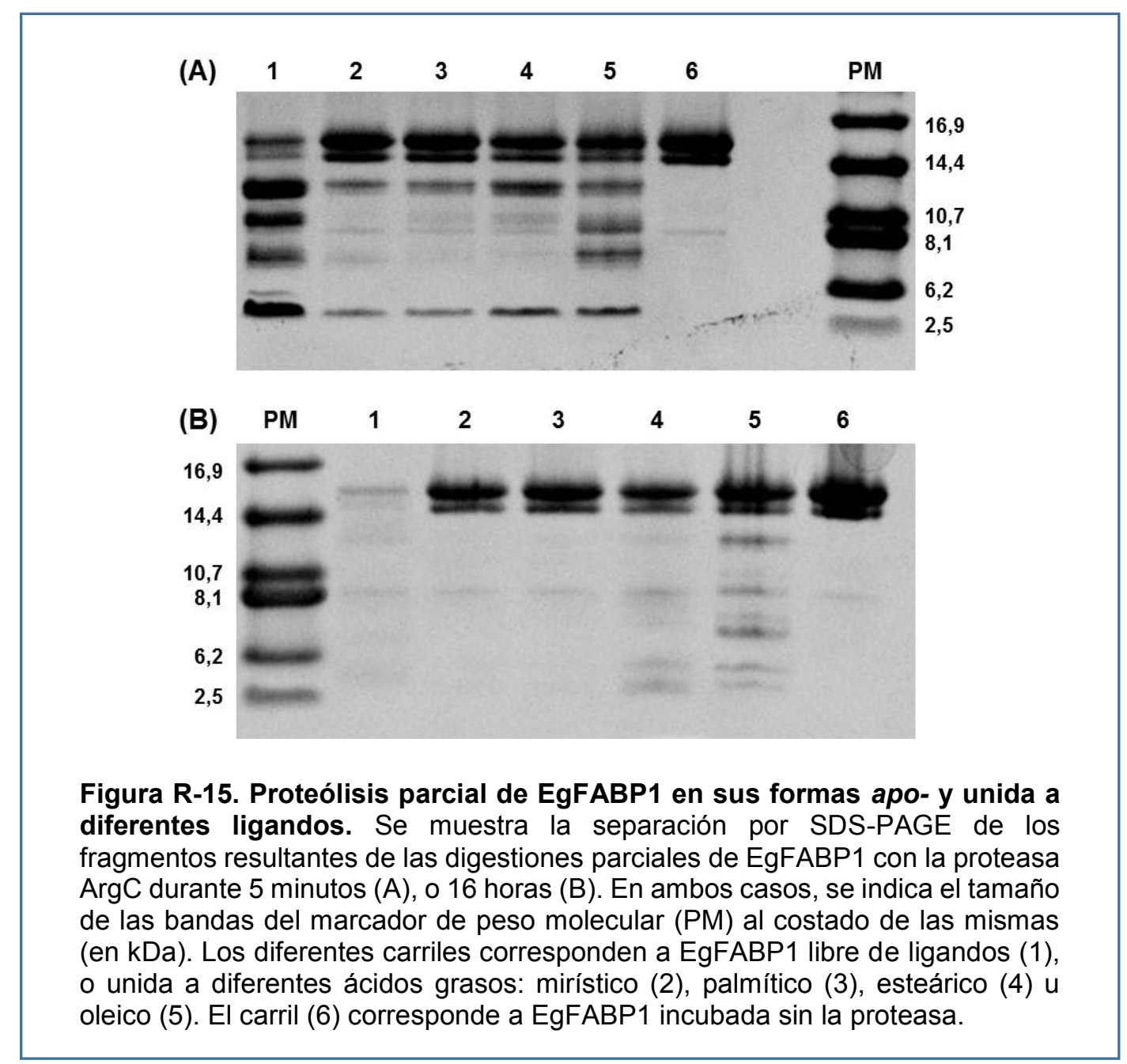

De un modo o de otro, resulta claro que la unión de diferentes ligandos es capaz de inducir cambios en la proteína que son dependientes del compuesto unido a la misma. Esto podría tener implicancias funcionales, tal como se ha descripto para otros miembros de la familia de las FABPs (Armstrong et al., 2014; Gillilan et al., 2007; Storch \& McDermott, 2009), aunque se requerirían mayores investigaciones para poder concluir algo al respecto.

\subsubsection{Análisis por dicroísmo circular de la interacción de EgFABP1 con ácidos grasos}

Tal como se mencionó en el ítem 3.1.3 de la sección Resultados, el dicroísmo circular es una técnica que permite analizar tanto la estructura secundaria como terciaria de las proteínas. Por este motivo, se la utilizó para evaluar si, efectivamente, era posible detectar cambios 
conformacionales en EgFABP1 cuando la misma se encuentra unida a diferentes ligandos. Para ello, se incubó EgFABP1 con ácido palmítico u oleico, y se midieron los espectros tanto en el UV lejano como en el UV cercano para ambas formas de holo-EgFABP1, así como para apo-EgFABP1 (Ver detalles en el ítem 2.2.3 de la sección Materiales y Métodos).
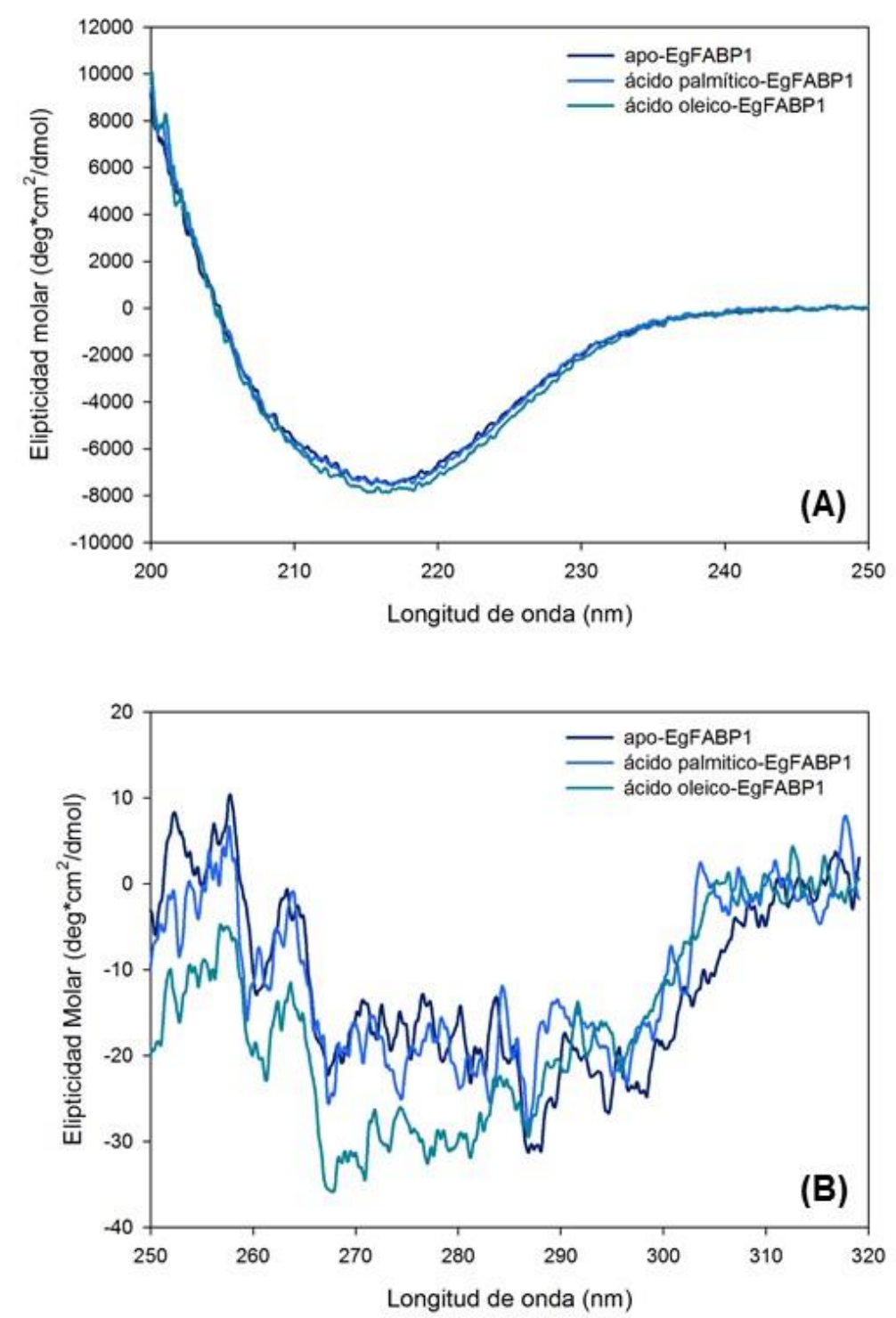

Figura R-16. Espectros de dicroísmo circular de EgFABP1 en sus formas apo- $y$ unida a diferentes ligandos. En el panel $A$ se muestran los espectros en el UV lejano de apo-EgFABP1 y de EgFABP1 unida a ácido palmítico o ácido oleico. El panel B muestra los espectros respectivos en el UV cercano.

En la Figura $R-16$ se puede observar que los espectros en el UV lejano correspondientes a EgFABP1 en su forma apo o unida a ácidos grasos no presenta diferencias. Esto puede ser interpretado como un indicio de que la unión de ligandos no genera una alteración apreciable a nivel de la estructura secundaria global de la proteína. Por su parte, en la región del UV 
cercano, sí se observan diferencias en el espectro de EgFABP1, en especial en el caso de la proteína unida a ácido oleico.

Esto indicaría que la unión con ácidos grasos altera de algún modo el entorno de los aminoácidos aromáticos de la proteína, ya sea por cercanía con el ligando, o por cambios conformacionales inducidos sobre la estructura terciaria de EgFABP1.

\subsubsection{Análisis de la interacción de EgFABP1 con análogos fluorescentes de ácidos grasos}

Una alternativa adicional al estudio de la interacción de EgFABP1 con ligandos se llevó a cabo empleando derivados fluorescentes de ácidos grasos. Para ello, se emplearon antroiloxiderivados de ácidos grasos, los cuales han sido muy utilizados para analizar las características de los sitios de unión de proteínas como las FABPs, debido a que sus propiedades espectrales son muy sensibles al entorno. Normalmente, estos compuestos tienen una intensidad de fluorescencia muy baja cuando se encuentran libres, en solución acuosa, y la misma aumenta notablemente cuando se une a una FABP (Storch et al., 1989). Por otra parte, como estos ligandos son también empleados para caracterizar las propiedades de transferencia de ácidos grasos desde proteínas a membranas fosfolipídicas, la determinación de la constante de disociación proteína-ligando, es un dato necesario para establecer las condiciones del experimento de transferencia, como se discutirá más adelante. Los antroiloxi-ácidos grasos utilizados fueron 16AP y 12AS, análogos de los ácidos palmítico y esteárico.

Tal como se puede ver en la Figura $R$-17, la unión de 12AS a EgFABP1 estuvo acompañada de un marcado aumento de la fluorescencia, acompañado de un corrimiento hacia el azul. Un desplazamiento del máximo de emisión a longitudes de onda más cortas (corrimiento al azul) indica que el fluoróforo se situa en un ambiente apolar, como puede ser, en este caso, el sitio de unión de EgFABP1.

En el caso de 16AP (Figura R-18), se observó una llamativa caída de la fluorescencia que, sin embargo, estuvo acompañada de un corrimiento hacia el azul, lo que sugiere que el ligando se estaría uniendo al bolsillo hidrofóbico de EgFABP1, pero que a su vez podría estar sufriendo algún tipo de supresión de la fluorescencia (o quenching) por parte de algún residuo

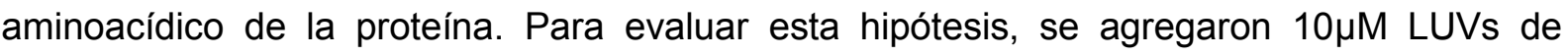
fosfatidilcolina a la cubeta donde se había llevado a cabo la titulación y se observó un marcado aumento de la fluorescencia. Esto indicó que la supresión de la fluorescencia del 16AP podía revertirse al pasar la sonda desde el sitio de unión de la proteína al ambiente hidrofóbico de las membranas fosfolípidicas de las LUVs. En ambos casos, 12AS y 16AP, las curvas 
obtenidas de la titulación de los ligandos con EgFABP1 alcanzaron la saturación, de acuerdo con modelos de unión proteína-ligando con estequiometría 1:1 (Ver ecuación del ajuste en la
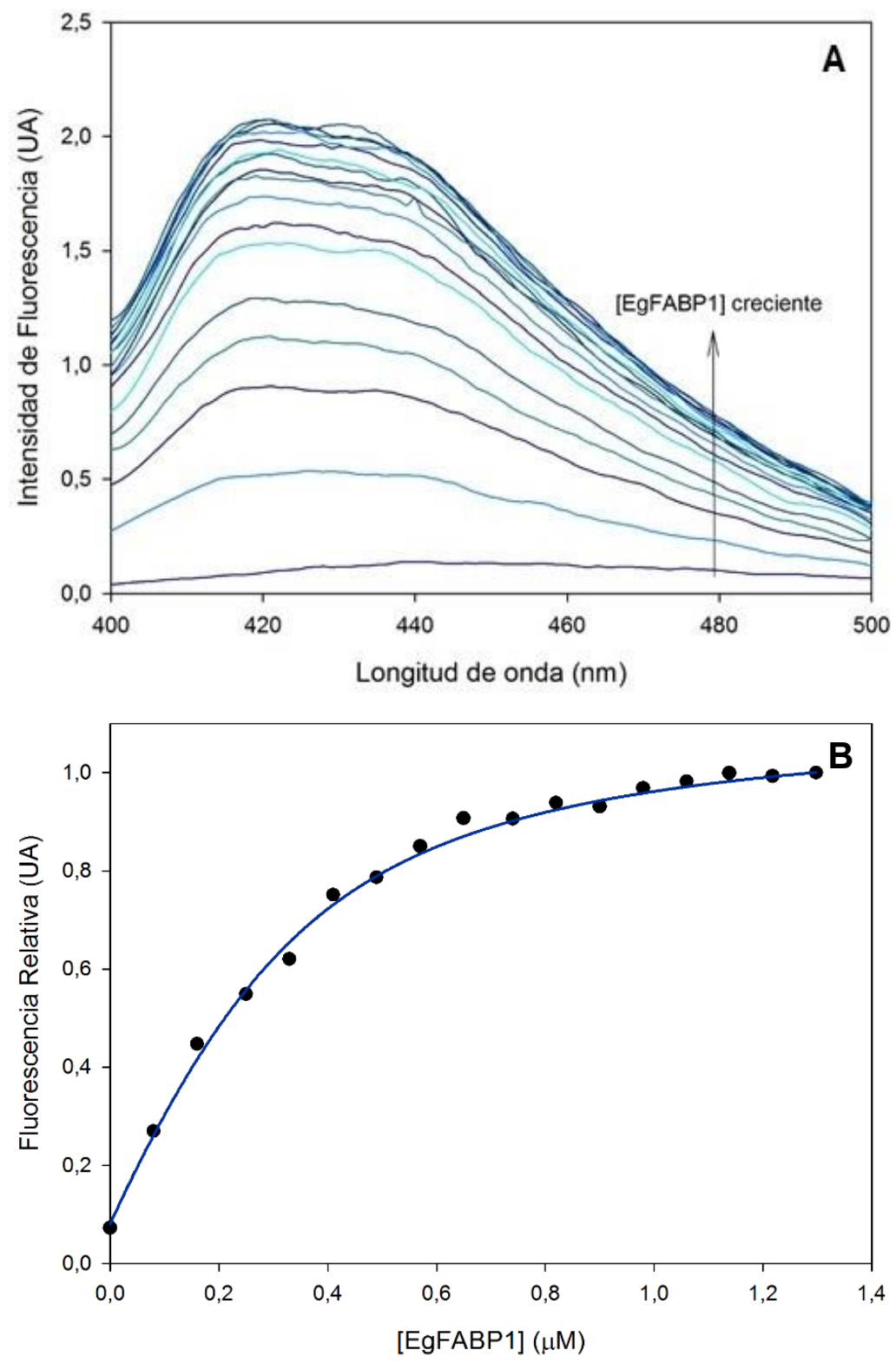

Figura R-17. Titulación fluorimétrica de 12AS con EgFABP1. En el panel (A) se muestran los espectros de emisión de 12AS unido a EgFABP1. Se registró la emisión de fluorescencia entre 400 y $500 \mathrm{~nm}$ resultante de excitar al fluoróforo con luz de longitud de onda de $383 \mathrm{~nm}$. El panel (B) muestra la isoterma de titulación obtenida al registrar los aumentos relativos de fluorescencia a $440 \mathrm{~nm}$. La curva mostrada en azul representa la curva teórica de formación del complejo proteínaligando. Los datos se corresponden con un modelo de un único sitio de unión por monómero de proteína. (Se muestra un experimento representativo de un total de cuatro)

sección Materiales y métodos, ítem 2.2.4). La $K_{D}$ obtenida para el $12 A S$ fue de $0,12 \pm 0,02 \mu \mathrm{M}$, y para el 16AP, 0,013 $\pm 0,006 \mu \mathrm{M}$. Estos valores son del orden de los valores de $K_{D}$ determinados para otras FABPs y otros antroiloxi-derivados de ácidos grasos. Por ejemplo, 
se han reportado $\mathrm{K}_{\mathrm{D}}$ de 0,2 y 0,6 $\mu \mathrm{M}$ para la unión de 12AO (ácido 12-(9-antroiloxi)-oleico) a L-FABP e I-FABP de rata, respectivamente (Hsu \& Storch, 1996) y de $0,11 \mu \mathrm{M}$ para la unión de 2AP (ácido 2-(9-antroiloxi)-palmítico) a Sj-FABPc, una FABP de Schistosoma japonicum (McDermott et al., 2002).
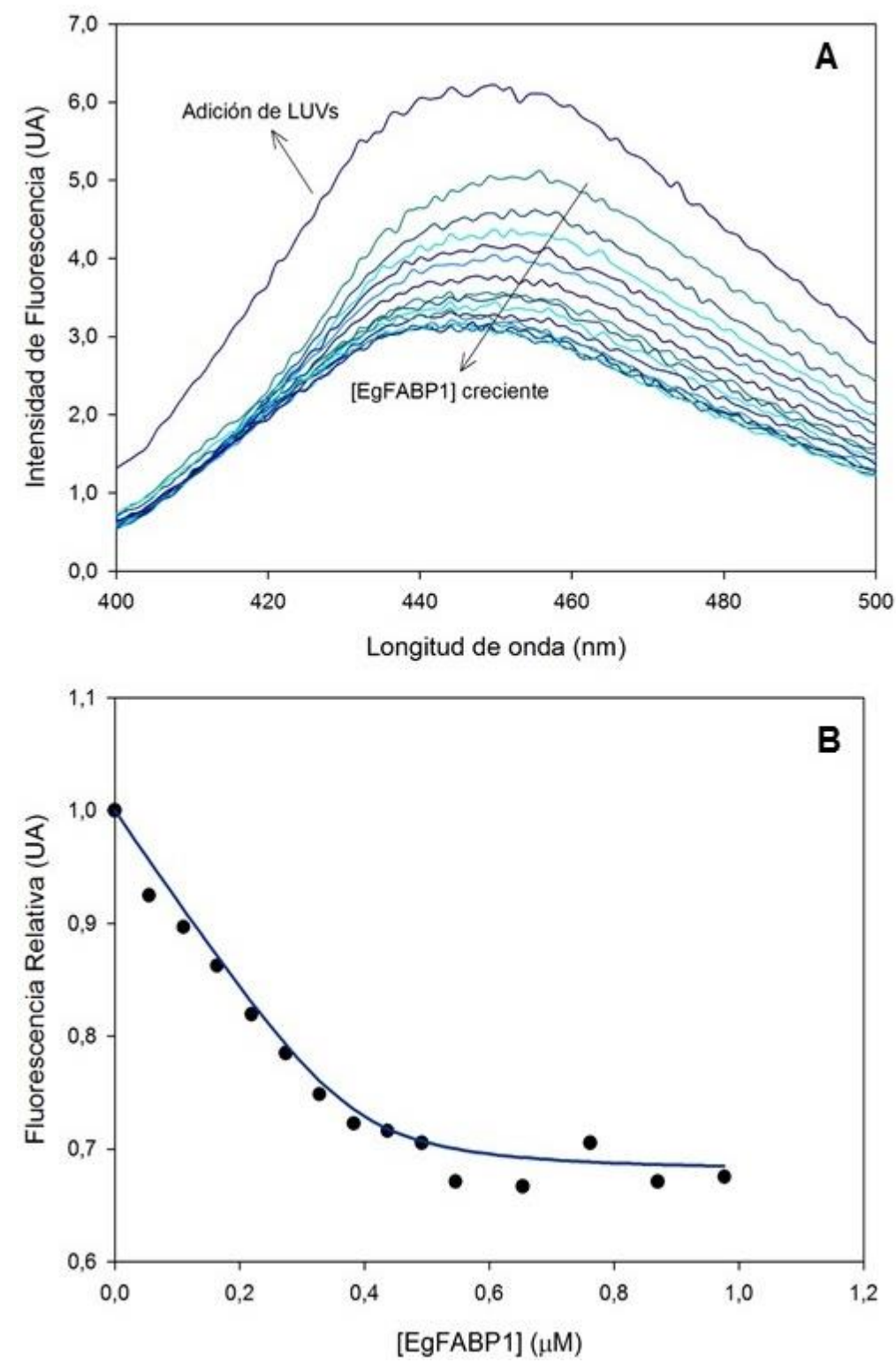

Figura R-18. Titulación fluorimétrica de 16AP con EgFABP1. En el panel (A) se muestran los espectros de emisión de 16AP unido a EgFABP1. Se registró la emisión de fluorescencia entre 400 y $500 \mathrm{~nm}$ resultante de excitar al fluoróforo con luz de longitud de onda de 383nm. Se muestra también la recuperación de la

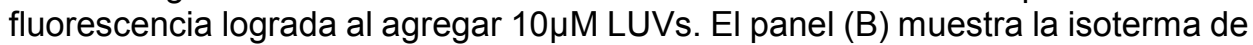
titulación obtenida al registrar los cambios relativos de fluorescencia a $440 \mathrm{~nm}$. La curva mostrada en azul representa la curva teórica de formación del complejo proteína-ligando. Los datos se corresponden con un modelo de un único sitio de unión por monómero de proteína. (Se muestra un experimento representativo de un total de tres) 
A pesar de que EgFABP1 presentó una mayor afinidad por el 16AP, para los estudios de transferencia de ligandos a vesículas fosfolipídicas artificiales se seleccionó el 12AS, ya que sus características de emisión de fluorescencia al unirse a EgFABP1 resultaron ser más similares a lo observado en estudios previos de transferencia de ligandos entre FABPs y vesículas (De Gerónimo et al., 2010; Falomir-Lockhart et al., 2006; Franchini et al., 2008).

\subsection{Análisis de la interacción de EgFABP1 con membranas}

\subsubsection{Determinación del coeficiente de partición $\left(K_{P}\right)$ de 12AS entre EgFABP1 y SUVs}

El coeficiente de partición da una medida de la distribución relativa de un ligando (el ácido graso) entre dos fases (proteína y membrana fosfolipídica). Esta medida sirve, además, para ajustar las condiciones de los experimentos de transferencia de ligandos, ya que para ellos es necesario asegurar una transferencia unidireccional del ligando desde la proteína a las membranas.

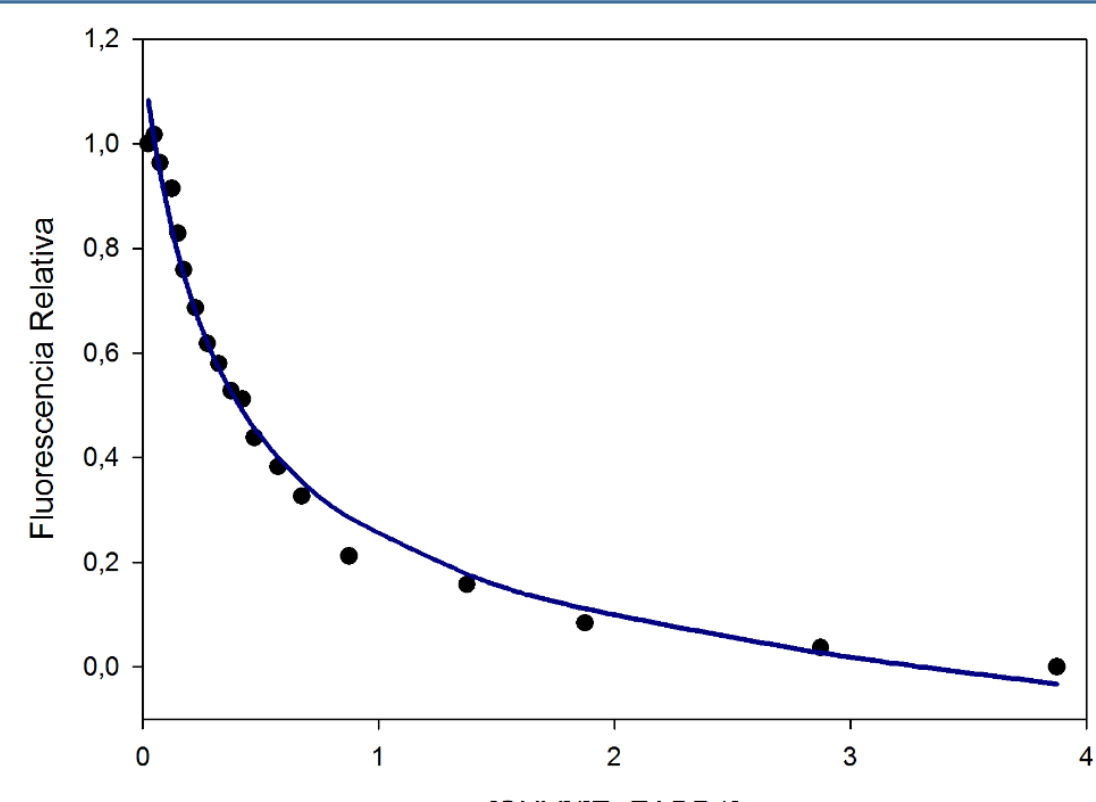

[SUV]/[EgFABP1]

Figura R-19. Titulación del complejo EgFABP1-12AS con SUVs de EPC/NBD-PC. Los valores de $K_{P}$ se obtuvieron registrando la emisión de fluorescencia del 12AS a 440nm luego de agregados sucesivos de SUVs conteniendo el quencher NBD. Los puntos representan los valores de fluorescencia relativa obtenidos experimentalmente, mientras que la línea azul muestra el ajuste obtenido aplicando la ecuación descripta en el ítem 2.3.2 de la sección Materiales y Métodos. Se muestran los datos de un experimento representativo de dos realizados. 
Para determinar el valor de $\mathrm{K}_{\mathrm{P}}$ se realizaron titulaciones del complejo EgFABP1-12AS con SUVs de EPC/NBD-PC (Ver Figura R-19). Como resultado, se obtuvo un valor de $K_{P}=0,48 \pm$ 0,23 ; lo que indica una leve preferencia del ligando $12 \mathrm{AS}$ por las vesículas fosfolipídicas.

\subsubsection{Transferencia de análogos fluorescentes de ácidos grasos desde EgFABP1 hacia vesículas unilamelares pequeñas.}

Uno de los enfoques mediante los cuales se exploró la capacidad de EgFABP1 de interactuar con membranas consistió en determinar el mecanismo de transferencia de ácidos grasos fluorescentes hacia membranas fosfolipídicas artificiales. Como se mencionó anteriormente, estos ensayos han permitido clasificar a las FABPs en dos grupos, de acuerdo al mecanismo empleado para transferir ácidos grasos. Por un lado se encuentran las FABPs de tipo "colisional", en las que la transferencia del ligando a las membranas implica una interacción directa proteína-membrana, siendo dicha interacción el paso limitante de la velocidad. El otro grupo lo constituyen las FABPs de tipo "difusional", en las que la transferencia de ligandos a membranas es independiente del contacto proteína-membrana, y el paso limitante de la velocidad de transferencia está dado por la disociación del complejo proteína-ligando (Hsu \& Storch, 1996; Schroeder et al., 1998; Storch \& Córsico, 2008; Storch $\&$ McDermott, 2009). Se ha sugerido que las FABPs cuyo mecanismo de transferencia de ligandos es de tipo difusional constituirían un reservorio citosólico de ácidos grasos (u otros ligandos), o bien podrían estar involucradas en el transporte de ligandos a otras proteínas; mientras que las que poseen un mecanismo colisional podrían estar implicadas en interacciones con dominios lipídicos o proteicos de membrana (Storch \& Córsico, 2008). Cabe destacar que varios de los motivos estructurales propuestos como responsables de determinar el mecanismo por el cual las FABPs transfieren sus ligandos a vesículas artificiales han sido también propuestos como motivos determinantes de algunas de las funciones atribuidas a estas proteínas (Storch \& McDermott, 2009).

Como se mencionó en el ítem 2.3.3 de la sección Materiales y métodos, estos experimentos consisten en el monitoreo de la fluorescencia de un análogo de ácido graso en función del tiempo cuando se mezclan (empleando un dispositivo de mezclado rápido) un complejo de EgFABP1 y ligando fluorescente con vesículas fosfolipídicas artificiales conteniendo un supresor (o quencher) de la fluorescencia de dicho ligando. Realizando dichas medidas para diferentes concentraciones o composiciones de las vesículas es posible determinar el mecanismo de transferencia de ligandos de la proteína.

La Figura R-20 muestra que cuando una cantidad fija del complejo EgFABP1-12AS se mezcla con concentraciones crecientes de SUVs zwitteriónicas, la velocidad de transferencia del ligando fluorescente aumenta proporcionalmente yendo desde 0,04 $\pm 0,01 \mathrm{seg}^{-1} \mathrm{hasta}^{0,12}$ 
$\pm 0,03 \mathrm{seg}^{-1}$. Este resultado da indicios de que el mecanismo responsable de la transferencia de ligandos desde EgFABP1 a vesículas fosfolipídicas sería un mecanismo dependiente de la colisión entre la proteína y la membrana, ya que la velocidad de transferencia del ligando aumenta proporcionalmente con el aumento de la concentración de vesículas aceptoras, lo que se corresponde con un mecanismo de tipo colisional.

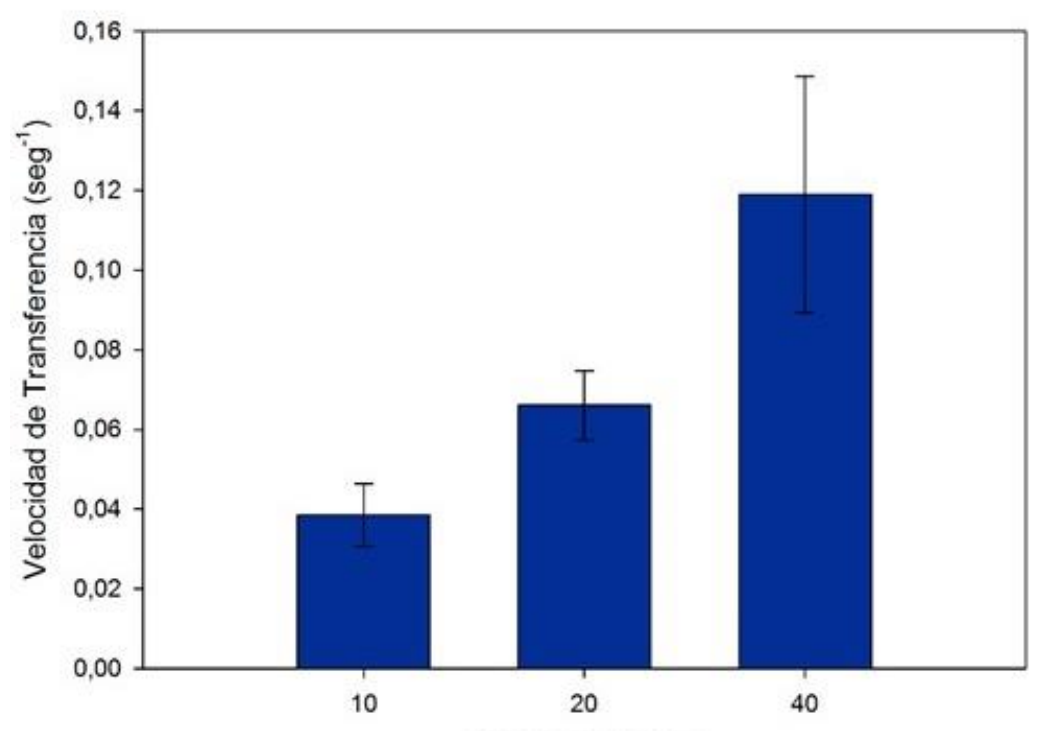

[SUV]/[EgFABP1]

Figura R-20. Efecto de la concentración de vesículas aceptoras sobre la velocidad de transferencia de 12AS desde EgFABP1 a SUVs de EPC/NBDPC. Los experimentos de transferencia se realizaron empleando relaciones vesículas/proteína ([SUV]/[EgFABP1]) de 10, 20 y 40. Se muestran los resultados promedio de cuatro experimentos \pm la desviación estándar (SD)

Por otro lado, si se tratara, efectivamente, de un mecanismo de transferencia dependiente de la interacción proteína-membrana, un cambio en la composición de las vesículas fosfolipídicas debería modificar la velocidad de transferencia del ligando fluorescente. Si fuera, en cambio, un mecanismo de tipo difusional, la velocidad de transferencia no debería verse modificada por un cambio en la composición de las membranas fosfolipídicas, ya que el paso limitante de la velocidad (la disociación del complejo proteína/ligando) es un evento temporal y espacialmente independiente del contacto con la membrana. Para evaluar el efecto de la composición de las SUVs sobre la velocidad de transferencia del 12AS desde EgFABP1 a las vesículas fosfolipídicas, se realizó un ensayo similar al anterior, pero empleando vesículas fosfolipídicas con carga neta diferente. Se utilizaron vesículas zwitteriónicas de EPC, vesículas con $25 \%$ de PS, que contiene una carga neta negativa por molécula, y vesículas con $25 \%$ de $\mathrm{CL}$, que posee dos cargas netas negativas por molécula (Ver detalles en los ítems 2.3. 1 y 2.3.3 de la sección Materiales y métodos). La Figura R-21 muestra los resultados de 
dichos experimentos. Tal como se puede apreciar en dicha figura, el aumento de carga neta negativa sobre la superficie de las SUVs provocó un aumento notable de la velocidad de transferencia del ácido graso hacia las mismas, lo cual es acorde a lo observado para otras FABPs con mecanismo colisional de transferencia de ligandos (Córsico et al., 2005, 1998; Falomir-Lockhart et al., 2006; Franchini et al., 2008; McDermott et al., 2002).

Se probó también el efecto del aumento de concentración de vesículas cargadas sobre la velocidad de transferencia de ligando de EgFABP1 y, tal como se puede observar en la Figura $R$-22, la misma aumentó de manera proporcional al aumento de la concentración de SUVs, independientemente de si las mismas contenían PS (una carga neta negativa por molécula) o CL (dos cargas netas negativas por molécula) en su composición.

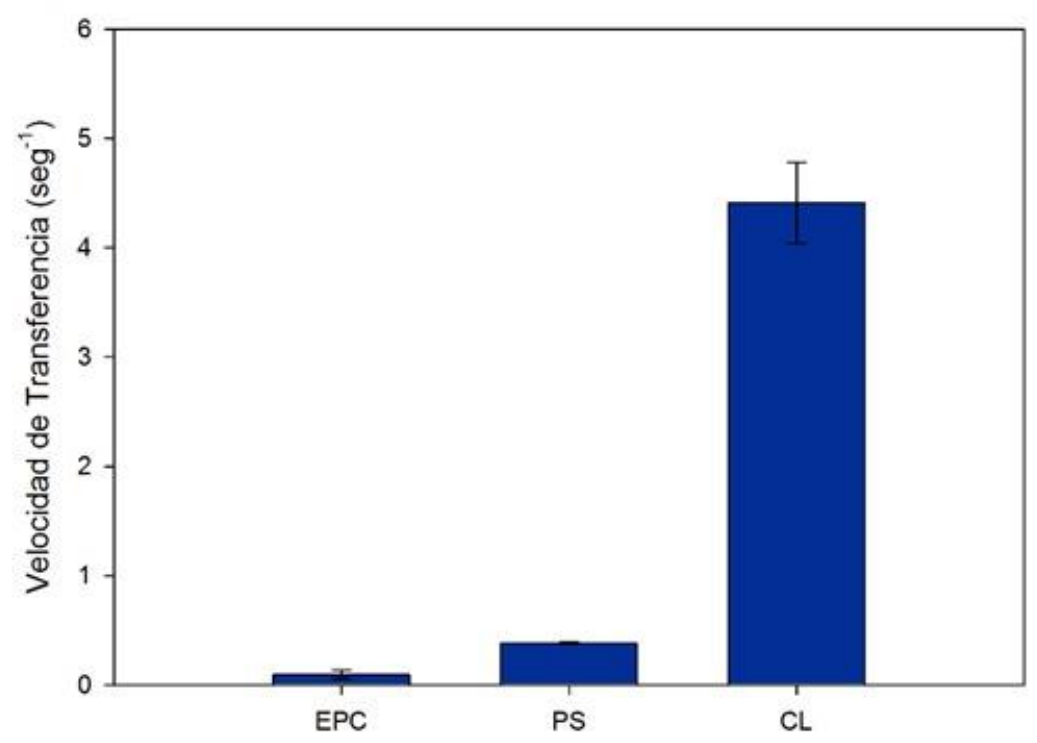

Figura R-21. Efecto de la carga superficial de las vesículas aceptoras sobre la velocidad de transferencia de 12AS desde EgFABP1 a SUVs. Los experimentos de transferencia se realizaron empleando relaciones vesículas/proteína ([SUV]/[EgFABP1]) de 20. Se emplearon vesículas de EPC (zwitteriónicas), EPC conteniendo $25 \%$ PS (una carga neta negativa por molécula) y EPC conteniendo $25 \% \mathrm{CL}$ (dos cargas netas negativas por molécula). Se muestran los promedios de dos experimentos \pm SD.

Finalmente, se evaluó también el efecto de la fuerza iónica del buffer sobre la velocidad de transferencia de ligandos desde EgFABP1 hacia SUVs. Para el caso de vesículas zwitteriónicas, se observó un marcado aumento de la velocidad de transferencia hacia las mismas al aumentar la fuerza iónica del buffer (Figura $R-23$, panel $A$ ) mientras que para las vesículas cargadas negativamente (Figura $R-23$, panel $B$ ) se observó una drástica caída en la velocidad de transferencia al aumentar la fuerza iónica de la fase acuosa. El apantallamiento de cargas provocado por una alta concentración salina podría explicar la caída en la velocidad de transferencia de 12AS hacia vesículas cargadas negativamente. 
Evidentemente, las interacciones electrostáticas entre EgFABP1 y las SUVs son de gran relevancia, ya que la velocidad de transferencia de 12AS hacia SUVs cargadas muestra una dependencia importante con las cargas de las vesículas y del medio circundante. Por otro
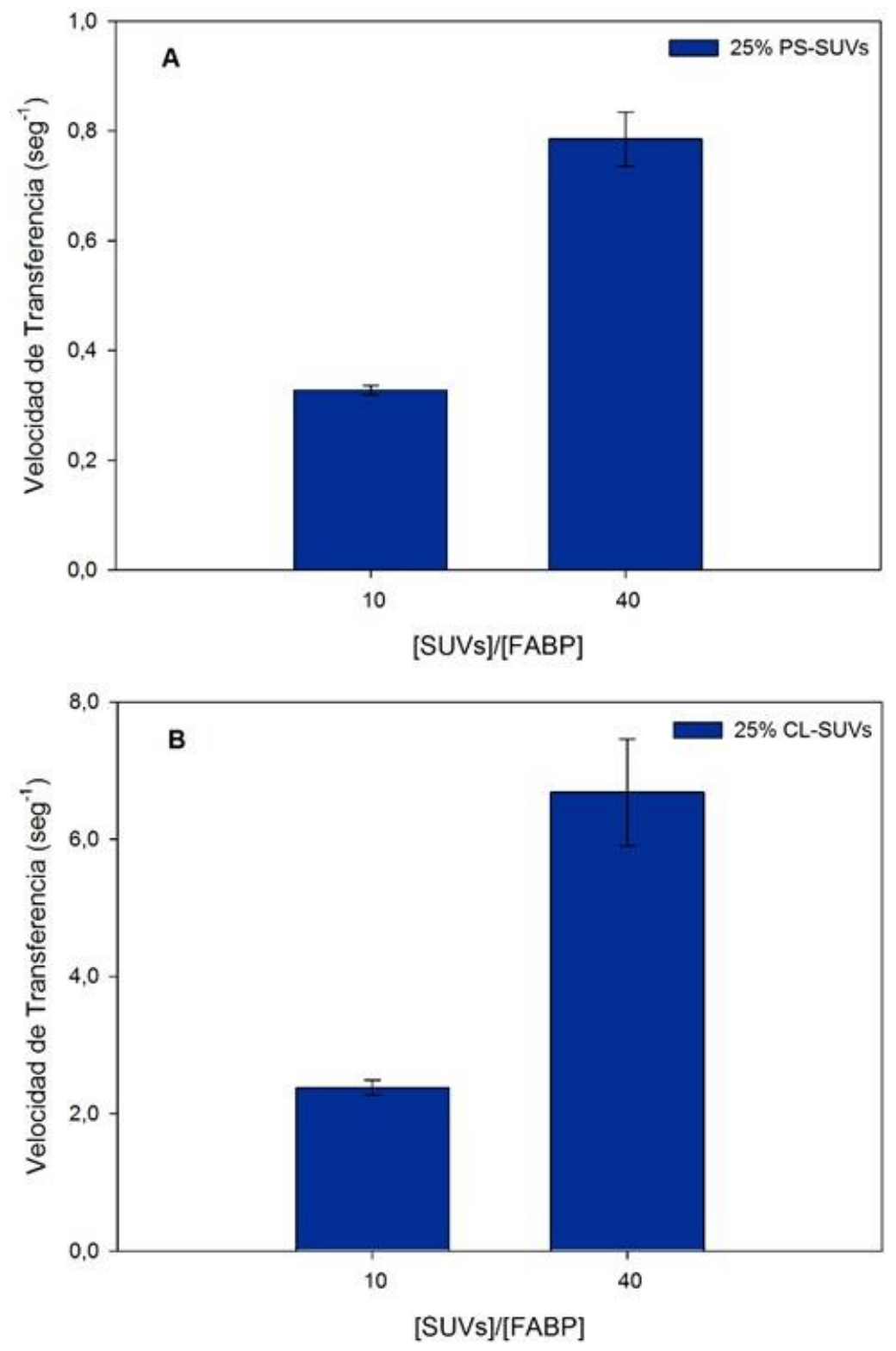

Figura R-22. Efecto de la concentración de vesículas aceptoras sobre la velocidad de transferencia de 12AS desde EgFABP1 a SUVs con carga neta negativa. Los experimentos de transferencia se realizaron empleando relaciones vesículas/proteína ([SUV]/[EgFABP1]) de 10 y 40. Las vesículas de EPC/NBDPC utilizadas contenían $25 \%$ PS (A) o $25 \%$ CL (B) en su composición. Se muestran los promedios de dos experimentos \pm SD.

lado, las interacciones hidrofóbicas serían favorecidas por el aumento de la concentración salina, lo cual se evidencia en el aumento de la velocidad de transferencia de ligandos hacia vesículas zwitteriónicas en función de la fuerza iónica del buffer. El aumento de las 
interacciones hidrofóbicas estaría compensando de este modo la caída de las interacciones electrostáticas provocadas por el apantallamiento de cargas.

Los resultados obtenidos permiten incluir a EgFABP1 en el grupo de las FABPs "colisionales", al cual pertenecen también, entre otras, SjFABPc de S. japonicum, y A-FABP, $\mathrm{H}-\mathrm{FABP}$ e I-FABP de mamíferos. De este modo, se podría especular que EgFABP1 sería del tipo de FABPs encargadas de direccionar ligandos hacia diferentes organelas o vías metabólicas dentro de la célula (McDermott et al., 2002).
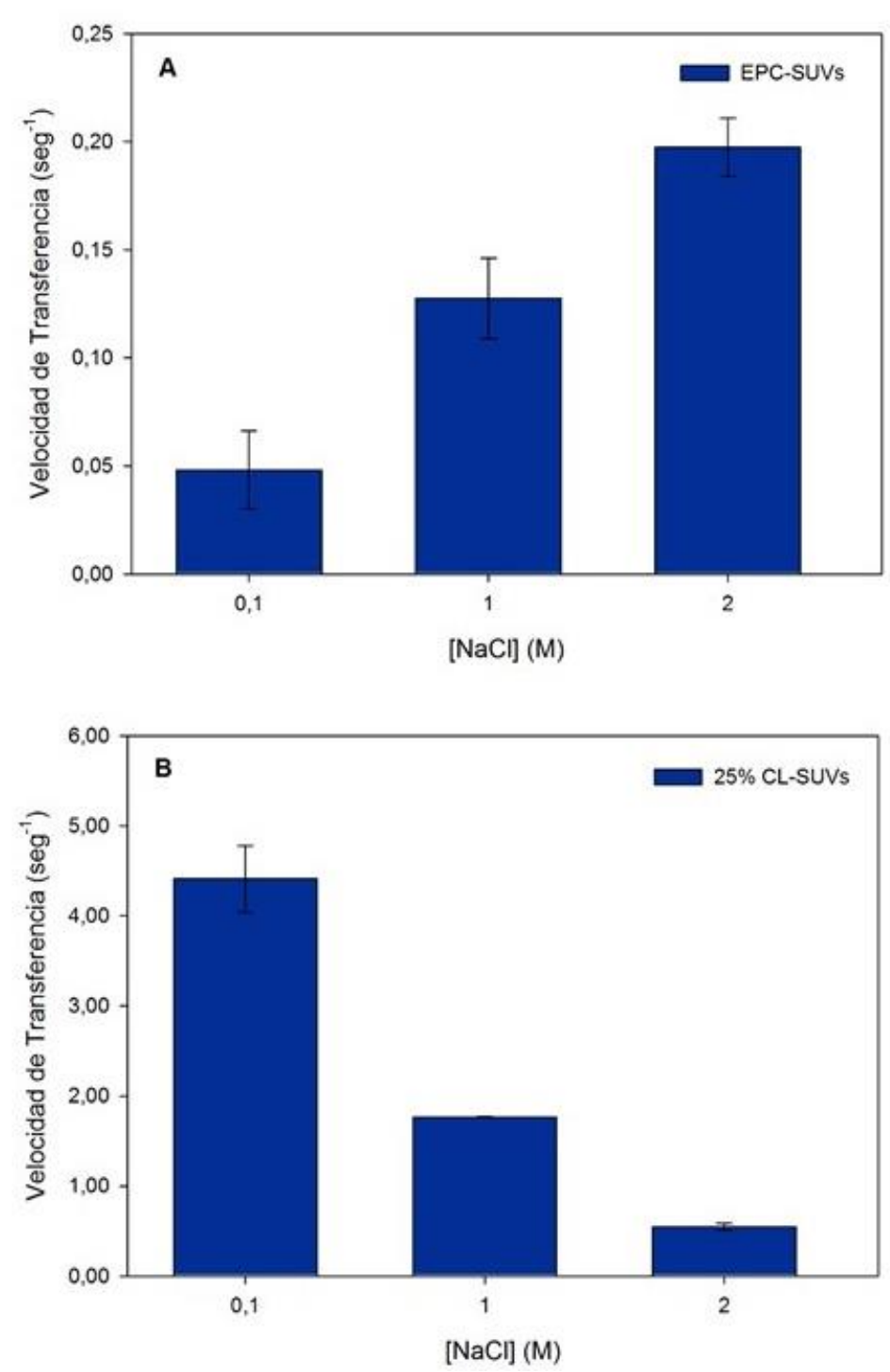

Figura R-23. Efecto de la fuerza iónica del buffer sobre la velocidad de transferencia de 12AS desde EgFABP1 a SUVs con carga neta negativa. Los experimentos de transferencia se realizaron empleando relaciones vesículas/proteína, [SUV]/[EgFABP1], de 20 y concentraciones crecientes de $\mathrm{NaCl}$ en el buffer. Se muestran los promedios de cuatro experimentos \pm SD (salvo la determinación a $2 \mathrm{M} \mathrm{NaCl}$ que corresponde a 2 experimentos diferentes). 
Los experimentos de transferencia de ligandos fluorescentes desde EgFABP1 hacia vesículas fosfolipídicas fueron llevados a cabo en colaboración con la Dra. Gabriela Alvite, con quien comparto la autoría del artículo "Direct Interaction between EgFABP1, a Fatty Acid Binding Protein from Echinococcus granulosus, and Phospholipid Membranes" (Pórfido et al., 2012), y en cuyo trabajo de tesis doctoral también se han presentado estos resultados.

\subsubsection{Determinación de la unión de EgFABP1 a SUVs por competencia con Citocromo c}

Con el objetivo de profundizar el estudio sobre la interacción de EgFABP1 con membranas fosfolipídicas se realizó un estudio de competencia por la unión a vesículas con cardiolipina entre CitC y EgFABP1 (Ver ítem 2.3.4 de la sección Materiales y métodos). Este experimento se basa en la interacción del CitC con membranas acídicas conteniendo CL en su composición. Si las membranas contienen además un fluoróforo adecuado, como el grupo dansilo del DPE, cuya fluorescencia pueda ser suprimida por interacción con el grupo hemo del CitC, la interacción del CitC con dichas vesículas puede ser monitoreada por medidas de fluorescencia (Mustonen et al., 1987). Si se adiciona EgFABP1 a las SUVs conteniendo DPE y $\mathrm{CL}$ antes del agregado de CitC, es de esperar que la fluorescencia aumente respecto al mismo ensayo sin EgFABP1, si es que esta última interactúa con las membranas. En otras palabras, si EgFABP1 interactúa con las SUVs, previene la interacción de ellas con el CitC y, por lo tanto, evita la supresión de la fluorescencia del DPE.

La Figura R-24 muestra que EgFABP1 es capaz de prevenir la interacción del CitC con SUVs aniónicas (con CL). Esta capacidad, sin embargo, resultó estadísticamente significativa sólo para el mayor agregado de EgFABP1 ensayado. Esto podría deberse a que la interacción de EgFABP1 con las membranas podría ser muy débil, o de una duración temporal demasiado corta, como para poder notar un cambio mayor a menores concentraciones. Asimismo, podría ser posible que la interacción de EgFABP1 con membranas se viera favorecida en su forma holo, unida a ligandos, más que en su forma libre de ácidos grasos. Sin embargo, por las características de este ensayo, esa no sería una variable factible de ser evaluada, ya que tan pronto como la proteína cargada con ligando se ponga en contacto con SUVs, la misma liberaría el ácido graso para pasar a su forma apo (tal como se observó en los experimentos de transferencia de ácidos grasos). Para la realización de estos ensayos se contó con la colaboración de la Dra. Valeria Silva (INIBIOLP, UNLP-CONICET). 


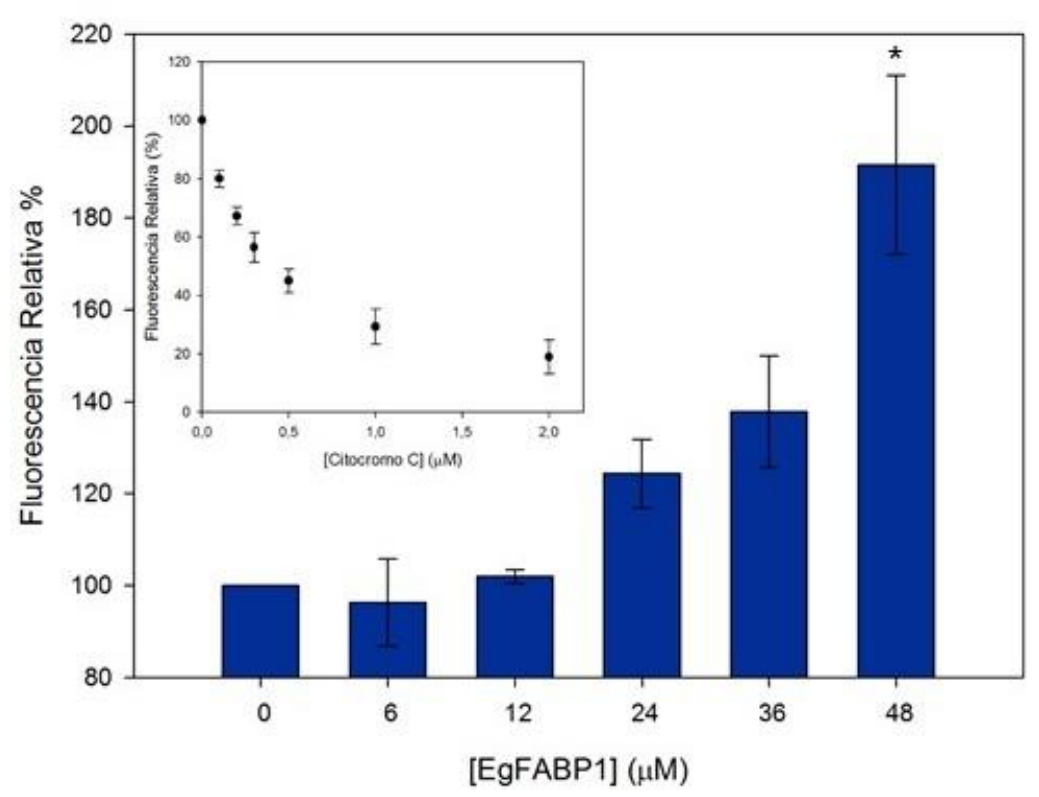

Figura R-24. Inhibición de la unión de CitC a vesículas fosfolipídicas aniónicas. En el gráfico inserto en la figura se puede observar como la adición de cantidades crecientes de CitC a SUVs conteniendo DPE produce una caída en la fluorescencia de este último. Por otro lado, se puede observar que la adición de EgFABP1 previa al agregado de CitC a las SUVs previene la supresión de la fluorescencia del DPE provocada por la interacción con el grupo hemo del CitC. Se muestran los promedios \pm SD de dos experimentos. El asterisco $\left(^{*}\right)$ indica diferencias significativas $(P<0,05)$ respecto al experimento sin agregado de EgFABP1.

\subsection{Identificación y análisis de FABPs de E. multilocularis}

Como se comentó en secciones anteriores, el trabajo con E. multilocularis presentado en esta tesis se llevó a cabo en el laboratorio del Dr. Klaus Brehm, en el Instituto de Higiene y Microbiología de la Universidad de Wurzburgo (Alemania). Cabe destacar que el laboratorio del Dr. Brehm ha sido uno de los pioneros en el desarrollo del cultivo de células primarias de E. multilocularis (Brehm \& Spiliotis, 2008; Spiliotis \& Brehm, 2009; Spiliotis et al., 2010, 2004) y en la aplicación de técnicas de silenciamiento génico en dichos cultivos (Spiliotis et al., 2010). El modelo de cultivo desarrollado en su laboratorio ha demostrado ser muy útil para el estudio de diversos aspectos de la biología molecular de E. multilocularis (Hemer et al., 2014; Koziol et al., 2014, 2013) y ha sido propuesto como un buen modelo para el estudio de $E$. granulosus. Asimismo, el Dr. Brehm y su grupo han participado en el proyecto de secuenciado de los genomas de estos cestodos, recientemente publicados (Tsai et al., 2013). La disponibilidad del sistema de cultivo de células primarias de E. multilocularis, así como el avanzado estado del borrador de su genoma en el transcurso de esta tesis, nos llevó a 
proponer la identificación de los genes ortólogos a egfabp1 y egfabp2 en dicho organismo, y el empleo de siRNAs para intentar silenciar su expresión.

Para ello, primeramente se realizó una búsqueda de los genes de las FABPs en el genoma de E. multilocularis, realizando un alineamiento con las secuencias codificantes de egfabp1 y egfabp2 (Ver códigos de acceso para NCBI en el ítem 2.4.1 de la sección Materiales y Métodos), empleando la herramienta BLASTN del programa informático BioEdit. La gran similitud de secuencia entre los genes ortólogos de ambos organismos permitió encontrar las secuencias de ambas FABPs con gran facilidad. Con la finalidad de respaldar la información obtenida a partir del genoma, estas secuencias (denominadas emfabp1 y emfabp2 por analogía a las FABPs ya descriptas en $E$. granulosus) fueron contrastadas también con datos transcriptómicos disponibles en el laboratorio del Dr. Brehm.

Una vez determinadas las secuencias codificantes para EmFABP1 y EmFABP2 (Ver ítem 3.4.2) se procedió a realizar el diseño de los siRNAs que se utilizarían para intentar silenciar la expresión de estas proteínas. Se diseñaron dos siRNAs, uno dirigido contra emfabp1 y otro contra emfabp2, de tal manera que cada uno fuera específico para uno de los transcriptos (Ver Apéndice 7.1.2). Estos siRNAs, así como un siRNA control contra gfp, utilizado previamente por Mizukami et al. (2010) y Spiliotis et al. (2010), fueron empleados en ensayos de silenciamiento de EmFABP1 y EmFABP2, como se comentará en el siguiente ítem.

Luego de esta primera búsqueda, se realizaron búsquedas más exhaustivas en el genoma de E. multilocularis, contando para ello con la asistencia del Dr. Ferenc Kiss (Universidad de Wurzburgo, Alemania). Para ello, se utilizaron herramientas tales como TBLASTN, BLASTX, traducciones in silico y BLASTP. Se analizaron también bases de datos transcriptómicas de E. multilocularis y otros cestodos (como Taenia solium) y bases de datos de proteínas obtenidas por predicciones in silico. De esta manera, se obtuvieron tres secuencias adicionales que potencialmente codificarían para FABPs (Ver ítem 3.4.2). Las mismas fueron denominadas emfabp3, emfabp4 y emfabp5. Los números utilizados sólo designan el orden cronológico en el que fueron identificadas las secuencias. A partir de dichas secuencias, se diseñaron primers específicos (Ver Apéndice 7.1.1) que se utilizaron para analizar los niveles de transcripción de dichos genes en los experimentos de silenciamiento contra EmFABP1 y EmFABP2, de manera de evaluar la posible compensación por otras FABPs en las células tratadas. Cabe aclarar que para el caso de emfabp3, al momento de llevar a cabo los experimentos de silenciamiento no se contaba con información certera de su extremo 3', por lo que en dichos experimentos no se la tuvo en cuenta. Asimismo, los primers diseñados para estas FABPs también fueron empleados para el clonado de sus secuencias codificantes, como se describirá más adelante. En este caso, luego del surgimiento de versiones más curadas del genoma de E. multilocularis, fue posible diseñar primers para emfabp3. Es importante destacar que las secuencias predichas de emfabp1 a 4 actualmente se encuentran 
anotadas en el genoma de E. multilocularis disponible en el sitio web GeneDB, perteneciente al Wellcome Trust Sanger Institute (http://www.genedb.org/), no así emfabp5, cuya existencia sería propuesta por primera vez (según nuestro conocimiento) en la presente tesis.

\subsubsection{Ensayos de silenciamiento en células de E. multilocularis}

Para los ensayos de silenciamiento, se obtuvieron las células primarias de E. multilocularis a partir de metacestodos obtenidos in vitro, siguiendo el procedimiento descripto en el ítem 2.4.3 de la sección Materiales y métodos. Una vez aisladas las células y montados los cultivos axénicos, se procedió al tratamiento con siRNAs por electroporación. Tal como se mencionó, se emplearon siRNAs dirigidos contra EmFABP1 ( $\alpha-F A B P 1), E m F A B P 2$ ( $\alpha-F A B P 2)$ y un siRNA control contra GFP ( $\alpha$-GFP). Se incluyeron además controles sin electroporar y electroporados sin siRNA (mock). Las células electroporadas se sembraron en placas de cultivo de 96 pocillos, utilizándose 8 pocillos por cada tratamiento. Los cultivos fueron observados al microscopio diariamente, y se les cambió el medio cada dos días. Las muestras para la extracción de proteínas y ARN se tomaron a los 7 y 12 días luego de la electroporación, siguiendo el esquema publicado por Spiliotis et al. (2010). En la Figura R-25 se muestran imágenes representativas de cultivos correspondientes a distintos tratamiento a los 12 días post-electroporación. Las fotografías son previas a la cosecha de las células para la extracción de ARN y proteínas. Como se puede observar en la imagen, no se aprecian diferencias visibles en los diversos cultivos lo cual puede indicar que no hubo silenciamiento, o bien que el mismo no genera ningún fenotipo apreciable a simple vista. Las observaciones a tiempos menores mostraron resultados similares.

Con la finalidad de determinar si era posible detectar algún grado de silenciamiento a nivel proteico o de ARN mensajero (mRNA), se hicieron extracciones tanto de proteínas como de mRNA a partir de las células tratadas con siRNAs (Ver ítems 2.4 .4 y 2.4 .5 de la sección Materiales y Métodos), y se analizaron mediante Western Blot y RT-PCR semicuantitativa, respectivamente.

En la Figura R-26 se muestra un ejemplo de los Western Blots obtenidos. Tal como se observa en dicha figura, los niveles de FABP resultaron muy variables. Inclusive se observaron variaciones en los niveles de Elp, la proteína utilizada para normalizar los niveles de expresión de FABP. Dada la brevedad de la estadía en el laboratorio del Dr. Brehm, no pudieron ensayarse otras proteínas constitutivas como normalizadoras más adecuadas que Elp. En la Figura $R-27$ se muestra un gráfico con la cuantificación de la expresión relativa de FABPs respecto a Elp, de acuerdo a lo determinado por densitometría a partir de los Western Blots. Como se puede observar, la cuantificación no brindó resultados repetitivos entre los 
duplicados de cada condición, impidiendo sacar conclusiones certeras respecto al silenciamiento de las FABPs en células de E. multilocularis.
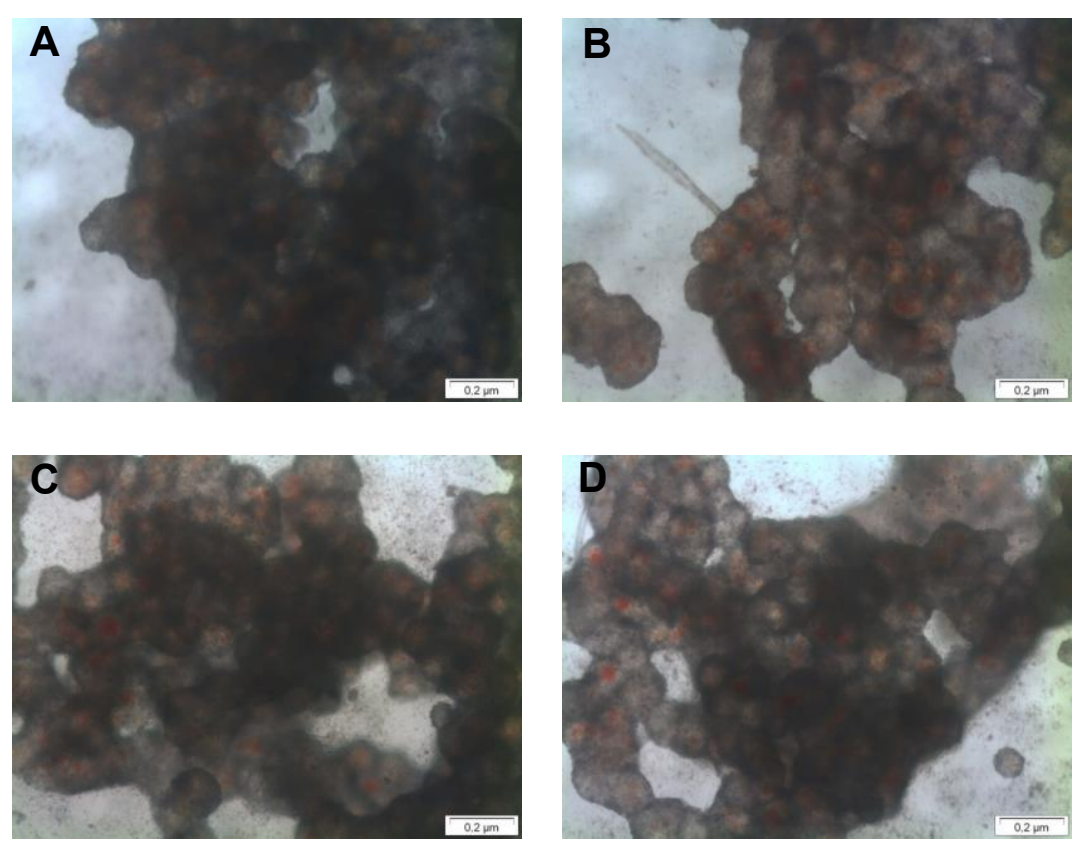

Figura R-25. Agregados de células primarias de E. multilocularis luego de 12 días en cultivo. El panel (A) corresponde a células sometidas a electroporación en ausencia de siRNAs; el (B) muestra células tratadas con siRNA $\alpha-G F P$; el (C) corresponde al tratamiento con siRNA $\alpha$-FABP1; y el (D), al $\alpha-F A B P 2$. Se muestran imágenes representativas de lo observado luego de 12 días de cultivo.

Las muestras de mRNA obtenidas se analizaron también por RT-PCR con la finalidad de detectar variaciones, si las hubiera, a nivel transcripcional. Para ello, se realizó la síntesis de cDNA, el cual luego fue utilizado como molde para las reacciones de PCR correspondientes. Las PCR se realizaron empleando diluciones seriadas 1/10 del ADN molde, y se utilizó un número de ciclos de amplificación tal que no se alcanzara la saturación (Ver ítem 2.4.5.5 de la sección Materiales y Métodos). Los resultados sugirieron que no se obtuvo un silenciamiento apreciable de EmFABP1 o EmFABP2, y que tampoco hubo compensación de las mismas por aumento de la expresión de las otras dos FABPs analizadas, ya que no hubo expresión detectable de EmFABP4 o EmFABP5 en ninguna de las condiciones ensayadas.

En la Figura R-28 se muestra, a modo de ejemplo, la comparación de las RT-PCR de las células electroporadas en ausencia de siRNAs (mock) con aquellas electroporadas con siRNA a-FABP1. Resultados similares se obtuvieron para los otros tratamientos. 
El experimento de silenciamiento se repitió empleando células extraídas a partir de metacestodos provenientes del aislamiento JAVA, y se incluyó un tratamiento con ambos siRNAs ( $\alpha-F A B P 1$ y a-FABP2). Los resultados, no obstante, fueron similares a los ya descriptos.

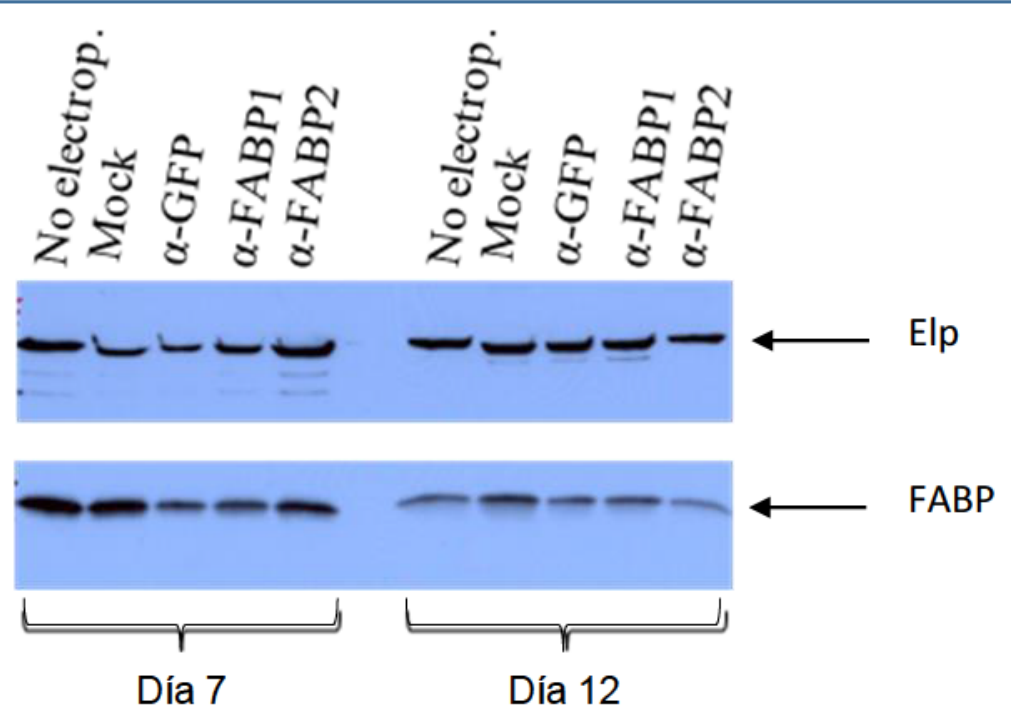

Figura R-26. Western Blots contra Elp y FABPs en células de $E$. multilocularis tratadas con siRNAs. En la figura se muestran, a modo de ejemplo, los resultados de uno de los Western Blots realizados con la finalidad de analizar los niveles de expresión de las FABPs luego de los tratamientos de las células primarias de $E$. multilocularis con diferentes siRNAs. Se muestran los resultados de los días 7 y 12 post-electroporación.

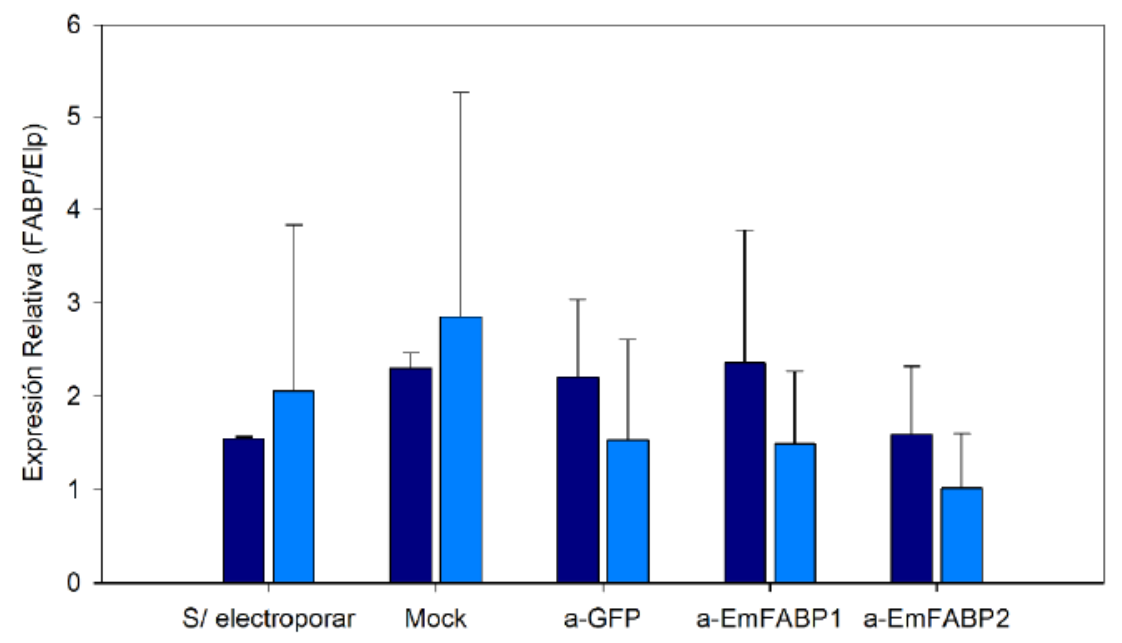

Figura R-27. Niveles de expresión relativa de FABPs en células de $E$. multilocularis tratadas con siRNAs. En la figura se muestra, la cuantificación realizada, a partir de los Western Blots, de la expresión relativa de las FABPs con respecto a la proteína Elp. Las barras azules muestran los resultados a los 7 días post-electroporación y las celestes corresponden a los 12 días postelectroporación. Los datos se obtuvieron por duplicado. 

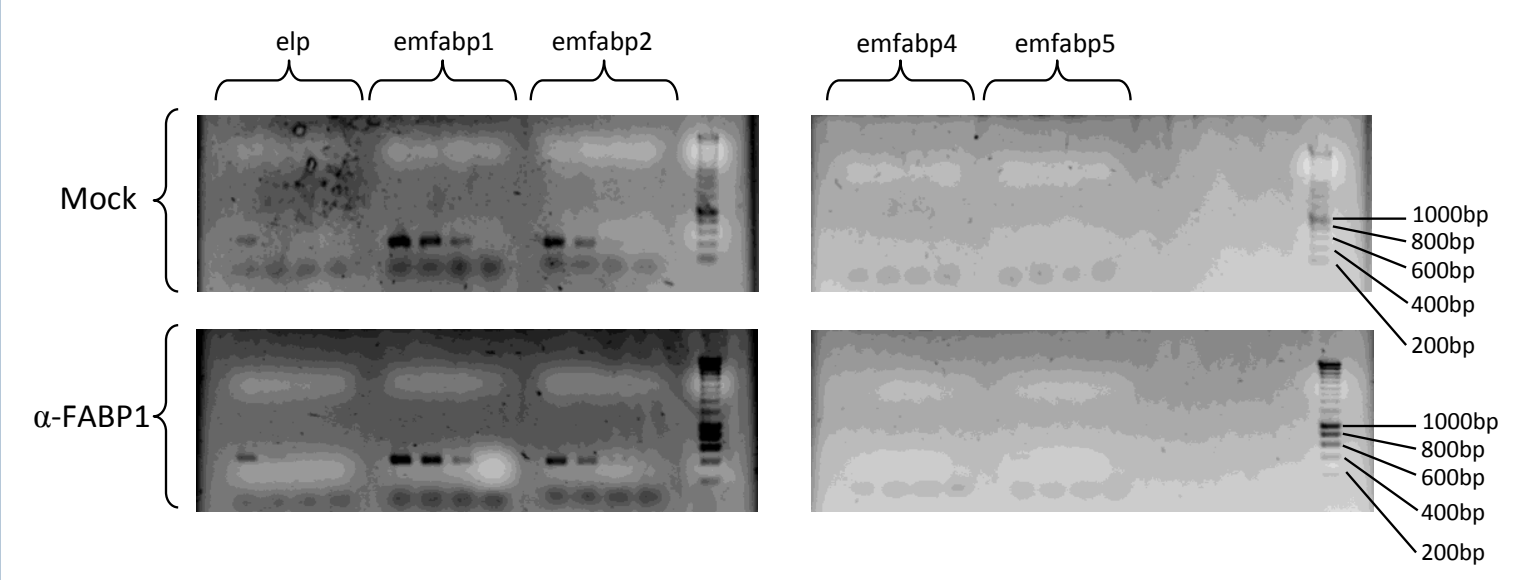

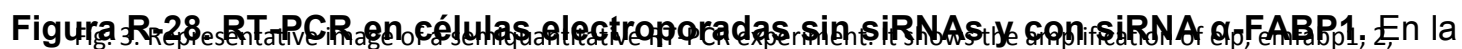

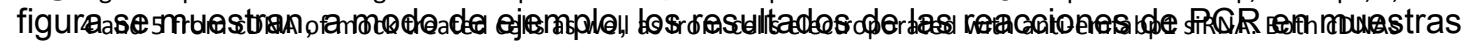

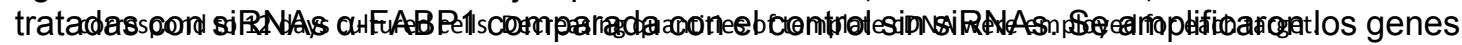
elp (normalizador), emfabp1, emfabp2, emfabp4 y emfabp5. A la derecha se indican los pesos moloculares correspondientes a las bandas del marcador do peso molocular. Las diferentes calles del gel (dentro de cada conjunto de PCRs realizadas) incluyen cantidades decrecientes de ADN molde: dilución 1/10, dilución 1/100, dilución 1/1000 y la última calle es un control sin ADN molde.

Los motivos por los cuales no se pudo lograr (o detectar) el silenciamiento de las FABPs de E. multilocularis son múltiples y muy variados. Por un lado, es posible que los tiempos posttratamiento a los cuáles se analizaron las muestras no fueran los adecuados para evaluar el silenciamiento de las FABPs. También es posible que la electroporación no haya sido suficientemente eficiente como para que los siRNAs ingresen a todas las células. Si ese fuera el caso, es posible que cualquier efecto que los mismos hubieran tenido sobre la expresión de las FABPs haya pasado desapercibido en un número de células "no tratadas" mucho mayor. Por otra parte, es posible que el gen elp no fuera el más adecuado para normalizar la expresión de las FABPs, en cuyo caso deberían analizarse otros posibles genes constitutivos para tomar como referencia. Recientemente, se ha sugerido un grupo de genes de $E$. granulosus s.s. y E. ortleppi que podrían ser usados como normalizadores en futuros experimentos (Espínola et al., 2014), aunque habría que probar que sean adecuados también para normalizar la expresión de genes de E. multilocularis. Finalmente, cabe destacar que las FABPs, en particular EmFABP1, es uno de los genes más expresados en E. multilocularis (Tsai et al., 2013), lo cual bien podría constituir una complicación adicional al intentar silenciar post-transcripcionalmente a dichos genes. 


\subsubsection{Clonado y caracterización de las FABPs de E. multilocularis}

\subsubsection{Clonado de las secuencias codificantes de las diferentes EmFABPs}

Tal como se comentó anteriormente, como consecuencia de las búsquedas bioinformáticas en el genoma de E. multilocularis, se encontraron cinco secuencias que codificarían para FABPs, entre ellas, los dos genes ortólogos a las FABPs ya descriptas en E. granulosus, EgFABP1 y EgFABP2. En la Tabla $R$-2, se muestra un resumen de algunas características importantes de las secuencias correspondientes a las FABPs predichas.

\begin{tabular}{|c|c|c|c|c|c|}
\hline Nombre & Nombre Sistemático GeneDB & Longitud $\mathrm{Gen}(\mathrm{pb})^{(\mathrm{a})}$ & Longitud $\operatorname{CDS}(\mathrm{pb})$ & Exones & Longitud Proteina (aa) \\
\hline EmFABP1 & EmuJ_000550000/EmuJ_002165500 (b) & 482 & 402 & 2 & 133 \\
\hline EmFABP2 & EmuJ_000549800 & 482 & 402 & 2 & 133 \\
\hline EmFABP3 & EmuJ_000551000 & 4878 & 435 & 2 & 144 \\
\hline EmFABP4 & EmuJ_000417200 & 3148 & 531 & 2 & 176 \\
\hline EmFABP5 & - & 1127 & 402 & 3 & 133 \\
\hline
\end{tabular}

Tabla R-2. Datos de las secuencias predichas para FABPs en E. multilocularis. La tabla muestra algunas características de las secuencias predichas, relevantes para las tareas de clonado de las mismas. Los nombres sistemáticos corresponden al genoma disponible en http://www.genedb.org/ (Wellcome Trust Sanger Institute).

(a) Cabe aclarar que no es estrictamente el gen completo lo que se considera en este caso, sino las secuencias genómicas comprendidas entre el codón de inicio y el codón de terminación de la transcripción de las proteínas predichas, lo cual incluye tanto la CDS como secuencias correspondientes a intrones.

(b) En el genoma de E. multilocularis aparecen dos secuencias iguales, correspondientes a EmFABP1. Se discutirá sobre este punto en secciones posteriores.

Con la finalidad de validar las observaciones realizadas a partir de los estudios bioinformáticos, se decidió clonar las CDS de dichos genes a partir de mRNA obtenido de células primarias de E. multilocularis obtenidas en el laboratorio del Dr. Brehm.

Para ello, parte de las células obtenidas para el segundo ensayo de silenciamiento (del aislamiento JAVA) se cultivaron durante dos días en condiciones axénicas, sin ningún tratamiento adicional, para luego extraer el mRNA y sintetizar cDNA (Ver ítem 2.4.5.4 de la sección Materiales y Métodos). Posteriormente, se realizaron reacciones de PCR utilizando dicho cDNA como molde y empleando el protocolo descripto en el ítem 2.4.6.1 de la sección Materiales y Métodos. Se realizó un protocolo de A-tailing, se ligaron los fragmentos de ADN al vector comercial $p G E M-T$ Easy, y se transformaron bacterias de la cepa E. coli $X L-1$ Blue. 
Los plásmidos recombinantes se rastrearon por screening blanco/azul. Se seleccionaron dos colonias blancas (con inserto) de cada una de las placas que contenían bacterias transformadas con ligaciones de $p G E M-T$ con emfabp1-4. Se realizaron cultivos de dichas colonias, se extrajeron los plásmidos y se digirieron con la enzima EcoRl, que corta a ambos lados del sitio múltiple de clonado del vector. Seguidamente, se realizó una electroforesis en gel de agarosa 1,2\% para visualizar los patrones de digestión. Como se puede observar en la Figura $R-29$, los tamaños aproximados de los insertos liberados en las distintas muestras se corresponden con lo esperado de acuerdo a las predicciones (402pb para emfabp1 y emfabp2, $435 \mathrm{pb}$ para emfabp3 y $531 \mathrm{pb}$ para emfabp4). Los clones de emfabp5 no se chequearon por digestión con enzimas de restricción, si no que directamente se mandaron a secuenciar junto con los otros. Se secuenciaron dos clones de emfabp3, emfabp4 y emfabp5, y un clon de

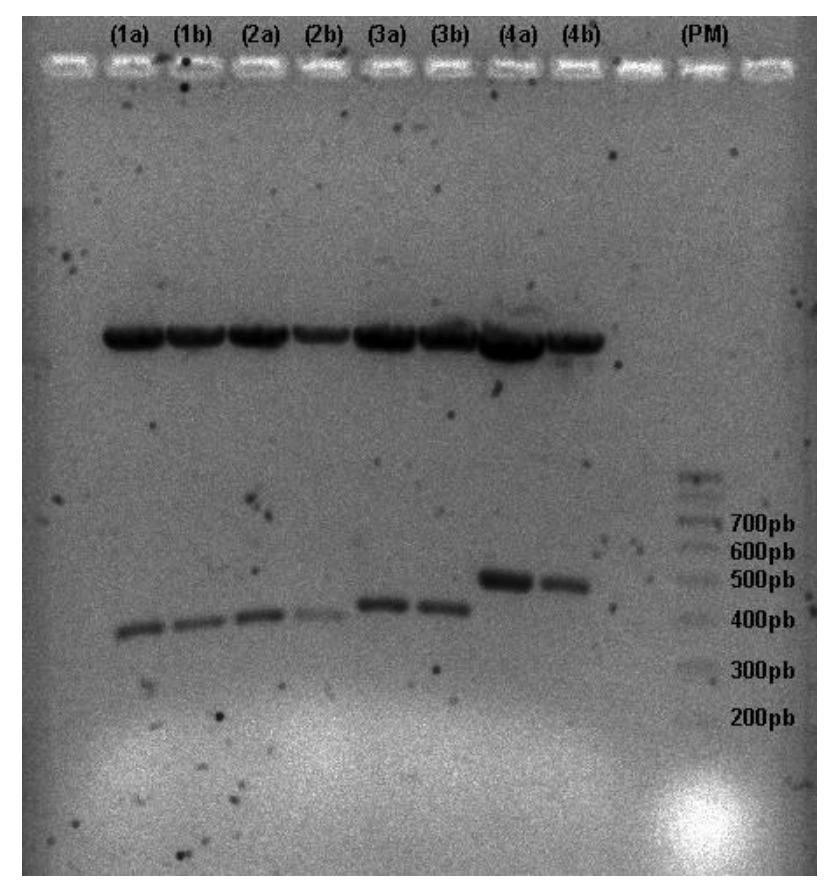

Figura R-29. Digestiones con EcoRI de los plásmidos pGEM-T recombinantes. La figura muestra una electroforesis en gel de agarosa donde se observan los insertos liberados al digerir los diferentes plásmidos con la enzima EcoRI. Las calles $1 \mathrm{a}$ y $1 \mathrm{~b}$ muestran las digestiones correspondientes a plásmidos conteniendo el inserto de EmFABP1 aislados de dos colonias diferentes. Por analogía, los indicados como 2a y 2b, 3a y $3 b$, $4 a$ y $4 b$, corresponden a EmFABP2, EmFABP3 y EmFABP4 respectivamente. A la derecha se indica el peso molecular de las bandas del marcador de peso molecular.

emfabp1 y emfabp2. Los secuenciados se realizaron utilizando un primer universal que se aparea con el promotor SP6 presente en el vector pGEM-T Easy (Ver Apéndice 7.2). Los alineamientos de las secuencias predichas con las obtenidas experimentalmente a partir de los plásmidos recombinantes se muestra en el Apéndice 7.3.2. Debido a que fue secuenciada una única hebra de ADN de cada uno de los clones, existen algunas bases no determinadas. 
No obstante, fuera de esos nucleótidos no determinados, lo secuenciado coincide con lo predicho. Para el caso de emfabp5, al haber quedado los insertos en direcciones opuestas en cada clon, se cuenta con el secuenciado de dos hebras diferentes. Para los análisis posteriores se emplearon las secuencias predichas.

\subsubsection{Caracterización bioinformática de las secuencias proteicas de las FABPs de E. multilocularis}

Como un primer paso para la caracterización de las secuencias de las posibles FABPs, se procedió a analizar las secuencias proteicas predichas en busca de dominios característicos que permitieran asignarlas a la familia de las FABPs. Para ello, se empleó la herramienta bioinformática InterPro, que permite contrastar la secuencia en estudio con diversas bases de datos de dominios proteicos. Las cinco secuencias fueron asignadas a la familia de las FABPs a través de distintos patrones presentes en su estructura primaria (Ver Figura R-30).

Por otra parte, se realizaron predicciones de estructura secundaria de las cinco secuencias, empleando la herramienta PSIPRED. En todos los casos, se predijeron estructuras con 10 hebras $\beta$ y dos $\alpha$-hélices entre las dos primeras hebras $\beta$, coincidiendo con la estructura típica de las FABPs (Ver figuras $R-31$ a $R$-35).

Si bien en la predicción para EmFABP1 aparecen 9 hebras $\beta$, se podría esperar que dicha proteína tenga el plegamiento típico de una FABP, ya que es la que más se parece a EgFABP1 (Ver más adelante), para la cual está resuelta la estructura cristalográfica (Jakobsson et al., 2003). Más aún, en la región entre las hebras $\beta C$ y $\beta D$, que es donde estaría faltando un giro en la predicción, ambas proteínas son idénticas.

En el caso de EmFABP4, cuya secuencia primaria es notablemente más larga que la de las demás FABPs, no se asigna una estructura determinada a su extremo carboxilo terminal, excepto por una corta hebra $\beta$. De demostrarse, en estudios posteriores, que EmFABP4 se traduce, se pliega en una estructura de FABP, y conserva todos los aminoácidos predichos, podría tratarse de una variante diferente de FABP, no descripta hasta el momento; en cuyo caso habría que ver qué plegamiento adopta la región carboxilo terminal y qué rol cumple en la función de dicha proteína. 


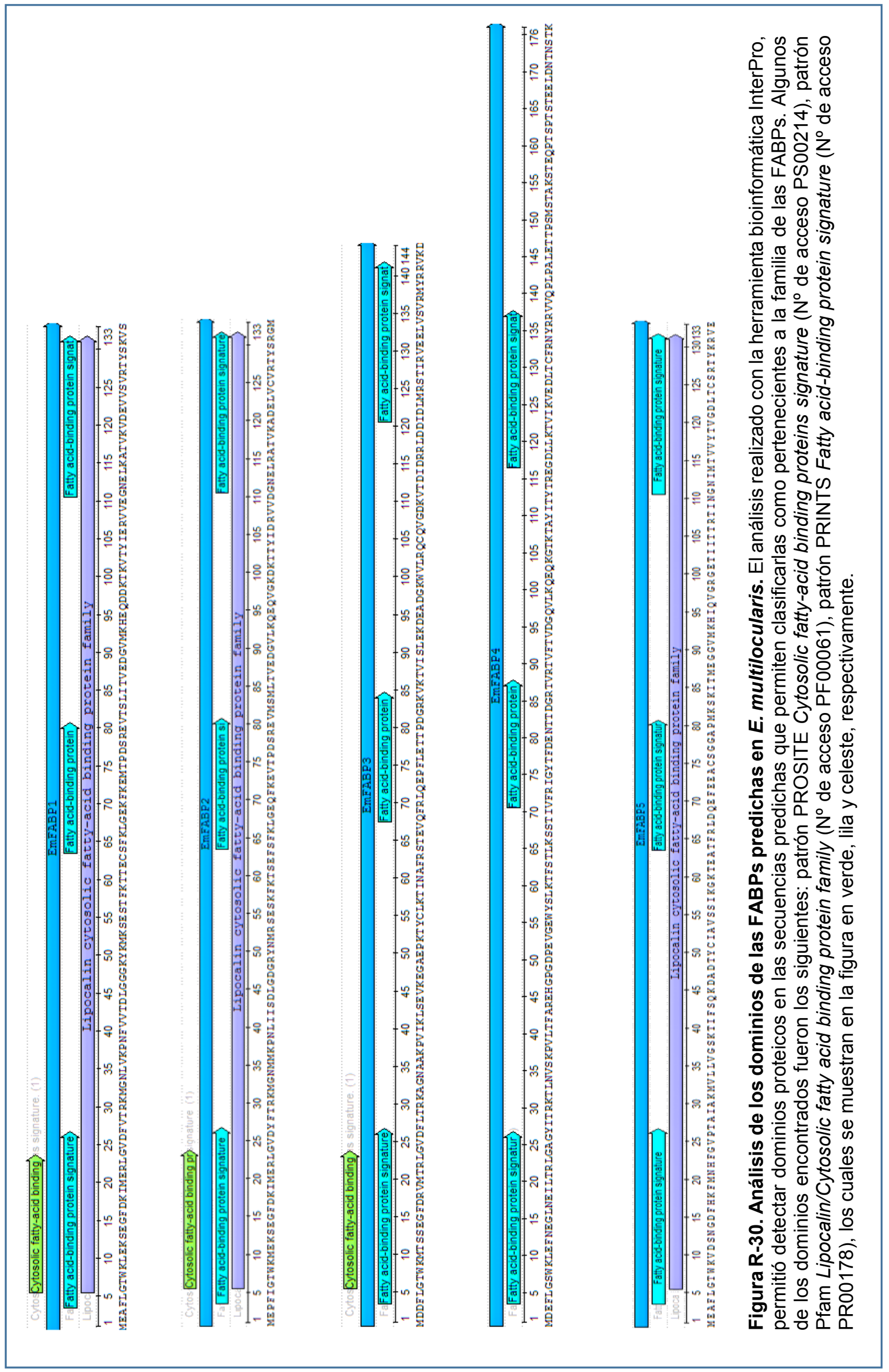



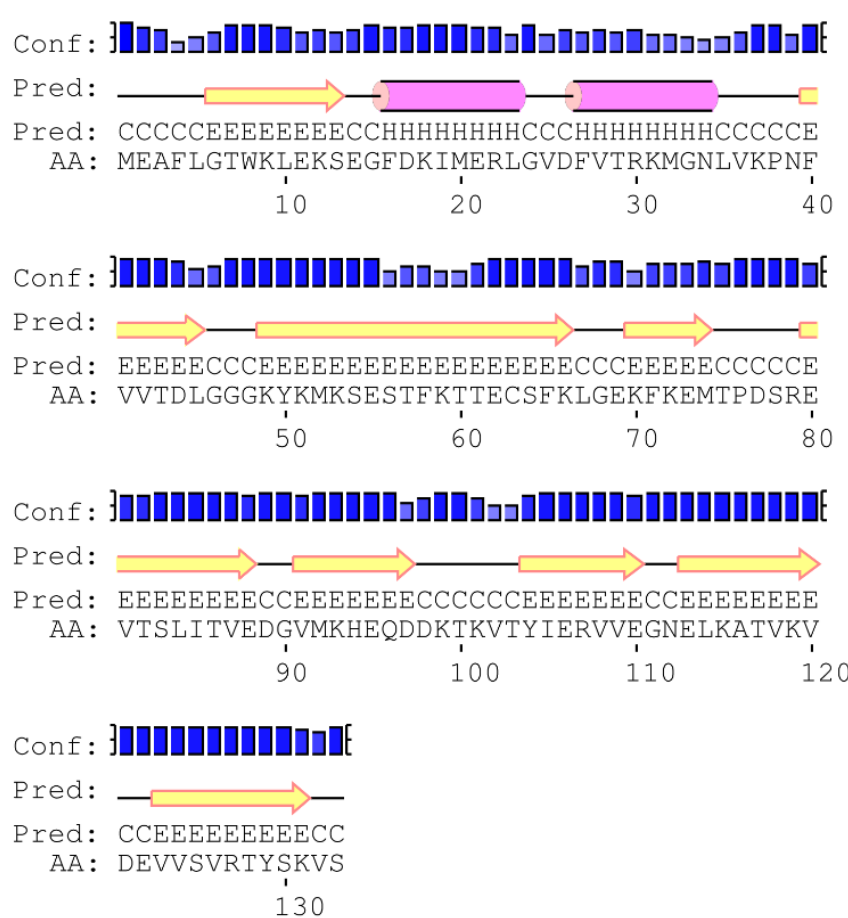

Figura R-31. Predicción de la estructura secundaria de EmFABP1. En la figura se muestra el resultado obtenido al analizar la secuencia de EmFABP1 con la herramienta PSIPRED de predicción de estructuras secundarias. La línea "Conf" corresponde al nivel de confianza de la predicción. Las líneas "Pred" muestran la estructura predicha para la secuencia: las flechas amarillas (oE) indican hebras $\beta$, los cilindros rosados $(\mathrm{oH})$ denotan hélices $\alpha$, y las líneas negras (o $C$ ) representan giros.
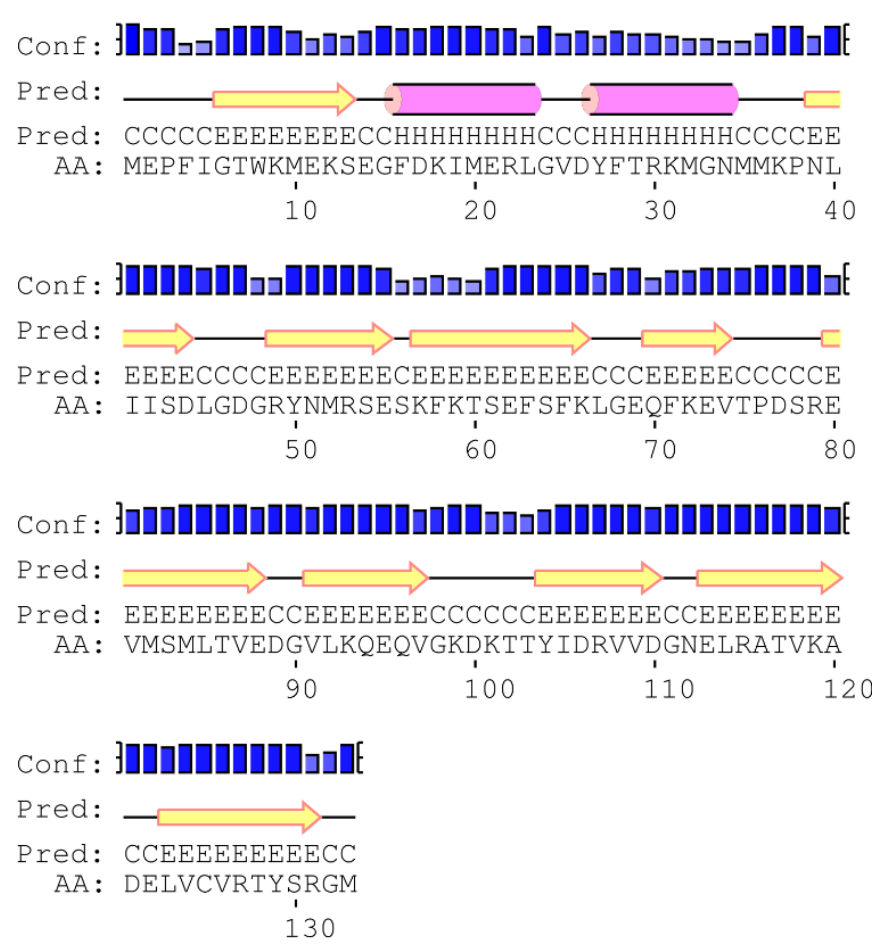

Figura R-32. Predicción de la estructura secundaria de EmFABP2. En la figura se muestra el resultado obtenido al analizar la secuencia de EmFABP2 con la herramienta PSIPRED de predicción de estructuras secundarias. Para las referencias, ver Figura $R-31$. 

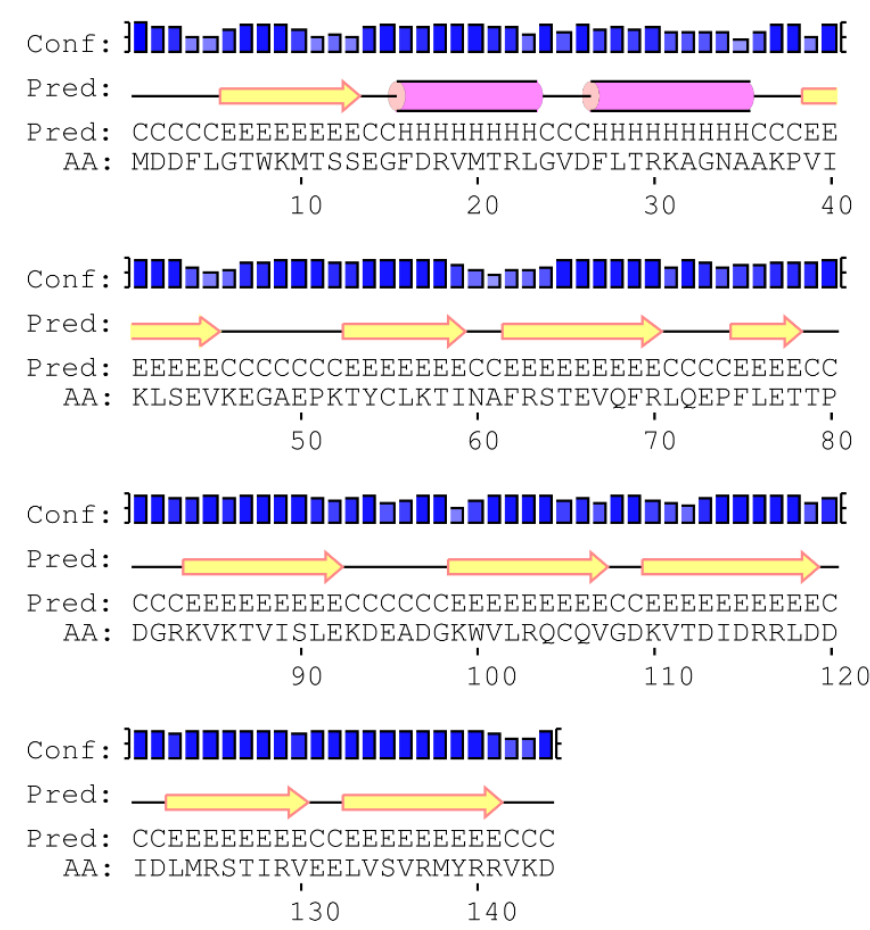

Figura R-33. Predicción de la estructura secundaria de EmFABP3. En la figura se muestra el resultado obtenido al analizar la secuencia de EmFABP3 con la herramienta PSIPRED de predicción de estructuras secundarias. Para las referencias, ver Figura $R-31$.
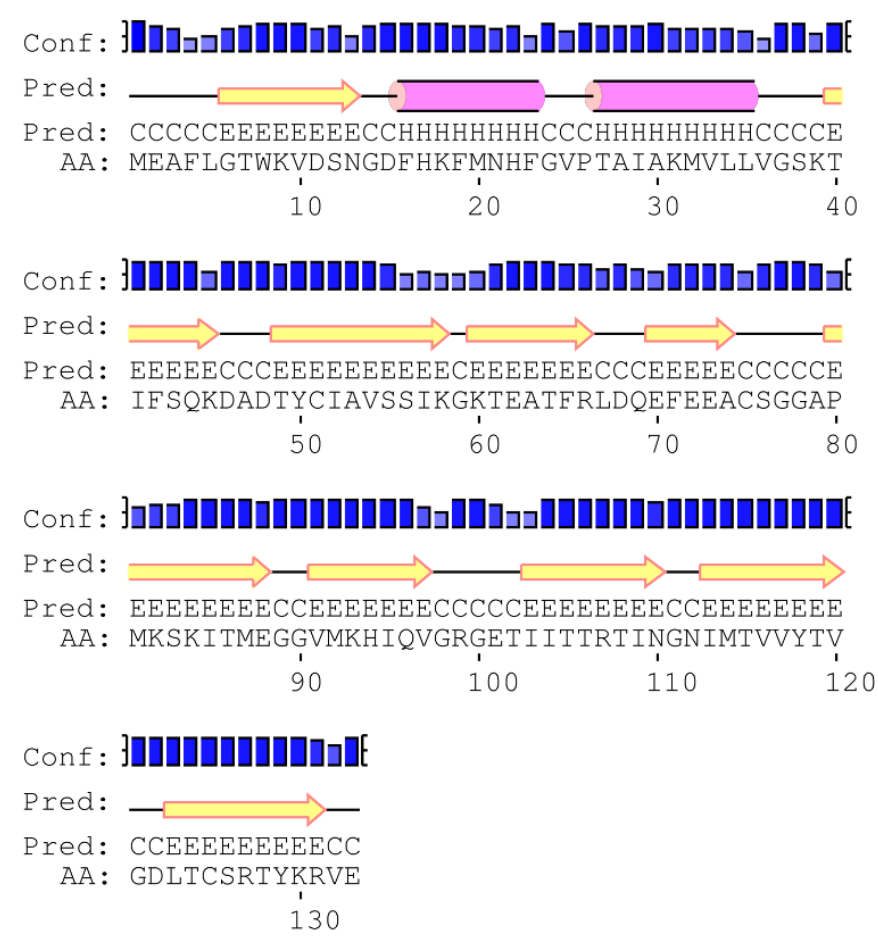

Figura R-34. Predicción de la estructura secundaria de EmFABP5. En la figura se muestra el resultado obtenido al analizar la secuencia de EmFABP5 con la herramienta PSIPRED de predicción de estructuras secundarias. Para las referencias, ver Figura $R-31$. 


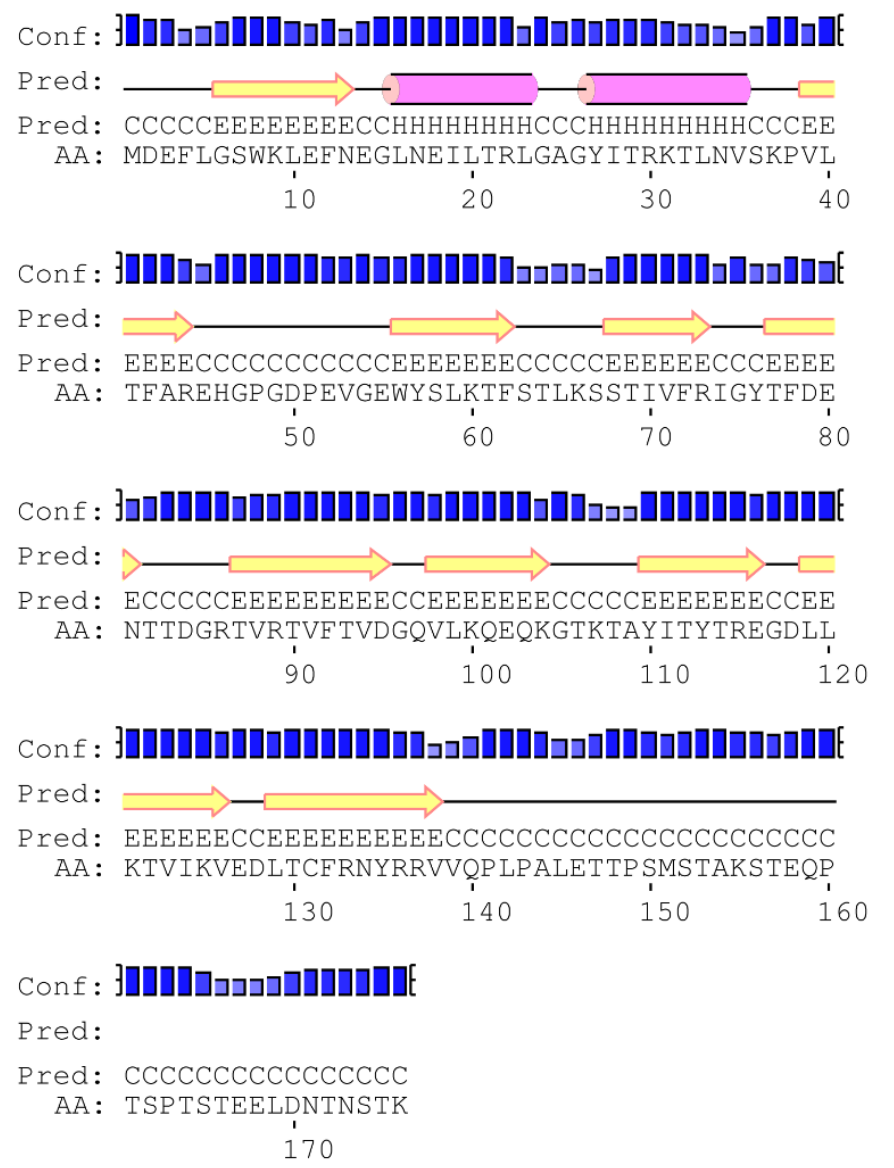

Figura R-35. Predicción de la estructura secundaria de EmFABP4. En la figura se muestra el resultado obtenido al analizar la secuencia de EmFABP4 con la herramienta PSIPRED de predicción de estructuras secundarias. Para las referencias, ver Figura $R-31$.

Con el objetivo de evaluar la similitud entre las secuencias de las proteínas predichas, se compararon de a pares las secuencias, tanto a nivel proteico como a nivel de las secuencias nucleotídicas correspondientes a las CDS (Ver Tabla R-3) empleando el programa informático BioEdit. Asimismo, con la finalidad de visualizar mejor la similitud de las secuencias, se realizaron alineamientos entre las cinco EmFABPs (Ver Figura R-36). Por otra parte, se alinearon también EmFABP1 y EmFABP2 (las cuales, como se discutirá más adelante, son muy semejantes a las ya descriptas y más estudiadas EgFABP1 y EgFABP2 de E. granulosus) con EmFABP3, EmFABP4 o EmFABP5, que son las que se diferencian más de las anteriores.

Como se puede observar en la Tabla $R-3$, tanto a nivel proteico como nucleotídico, EmFABP1 y EmFABP2 se asemejan mucho entre sí. EmFABP5, por su parte, a pesar de poseer una estructura génica diferente a las demás (Ver más adelante) es la que más se parece a EmFABP1 y EmFABP2; mientras que EmFABP4 pareciera ser la que más se aleja de las demás FABPs. Cabe recordar que EmFABP4 es también la que posee una secuencia más larga, de 176 aminoácidos, lo cual no es común para las FABPs. No obstante eso, cabe destacar que, aun teniendo en cuenta los porcentajes de similitud más bajos (cercanos al $20 \%$ 
entre EmFABP4 y EmFABP5), los mismos se encuentran dentro de los rangos de similitud de secuencias observados normalmente entre diversas FABPs (Storch \& Córsico, 2008).

\begin{tabular}{|c|c|c|c|c|c|c|}
\hline & EmFABP1 & EmFABP $1^{(b)}$ & EmFABP2 & EmFABP3 & EmFABP4 & EmFABP5 \\
\hline EmFABP1 & & $100,0 \%$ & $83,6 \%$ & $37,9 \%$ & $28,4 \%$ & $50,2 \%$ \\
\hline EmFABP $1^{(b)}$ & $100 \%$ & & $83,6 \%$ & $37,9 \%$ & $28,4 \%$ & $50,2 \%$ \\
\hline EmFABP2 & $71,6 \% / 87,3 \%$ & $71,6 \% / 87,3 \%$ & & $38,8 \%$ & $27,7 \%$ & $50,2 \%$ \\
\hline EmFABP3 & $22,9 \% / 41,7 \%$ & $22,9 \% / 41,7 \%$ & $24,3 \% / 41,6 \%$ & & $29,9 \%$ & $34,7 \%$ \\
\hline EmFABP4 & $16,4 \% / 27,7 \%$ & $16,4 \% / 27,7 \%$ & $14,7 \% / 26,5 \%$ & $14,7 \% / 33,9 \%$ & & $26,0 \%$ \\
\hline EmFABP5 & $32,8 \% / 48,5 \%$ & $32,8 \% / 48,5 \%$ & $31,3 \% / 49,2 \%$ & $15,3 \% / 23,6 \%$ & $\mathbf{9} \% / 20,3 \%$ & \\
\hline
\end{tabular}

Tabla R-3. Análisis de identidad de secuencias entre las diversas FABPs de E. multilocularis. En la tabla se muestran los porcentajes de identidad de secuencia para las diversas FABPs. En la parte inferior de la diagonal (en negrita) se muestran los valores de similitud de secuencia a nivel proteico, siendo los valores en color negro los correspondientes a identidad de secuencia y los que están en azul, los de similitud. Por encima de la diagonal se encuentran los porcentajes de identidad de secuencia a nivel nucleotídico de las CDS correspondientes.

(b) Tal como se mencionó previamente (y se discutirá más adelante) en el genoma de $E$. multilocularis se encontraron dos secuencias que serían copias exactas una de la otra y codificarían para EmFABP1.

A partir del alineamiento de secuencias, se puede observar una conservación notable de los aminoácidos a lo largo de la estructura primaria de las diversas proteínas. Hay ciertas posiciones en las que la conservación es total, entre las cuales se destacan dos de las tres posiciones involucradas en el motivo P2 de unión a ligando. Los análisis de la estructura cristalográfica de EgFABP1 revelaron que dicha proteína se unía a su ligando a través de dicho motivo, al igual que A-FABP y H-FABP, entre otras proteínas de la familia. Los residuos que forman el motivo P2 son, según la numeración para EgFABP1: $\operatorname{Arg}^{107}, \operatorname{Arg}^{127}$ y $\operatorname{Tyr}^{129}$ (Jakobsson et al., 2003). Como se puede ver en la Figura R-36, todas las FABPs predichas, salvo EmFABP4, conservan esa tríada de aminoácidos. En EmFABP4, el aminoácido que correspondería a la $\operatorname{Arg}^{107}$ es una Tyr. En otras muchas regiones de las proteínas existen aminoácidos que, aun no siendo idénticos, son semejantes en cuanto a polaridad, tamaño u otras características (destacados con fondo azul en la Figura R-36).

Al observar los alineamientos de EmFABP1 y EmFABP2 únicamente (Figura R-37) se observa la altísima conservación de los aminoácidos entre estas dos proteínas. Por otra parte, en los alineamientos de EmFABP1 y EmFABP2 con cada una de las otras tres FABPs por separado (Figura R-38), se observa también la conservación en diversas regiones de las proteínas. 


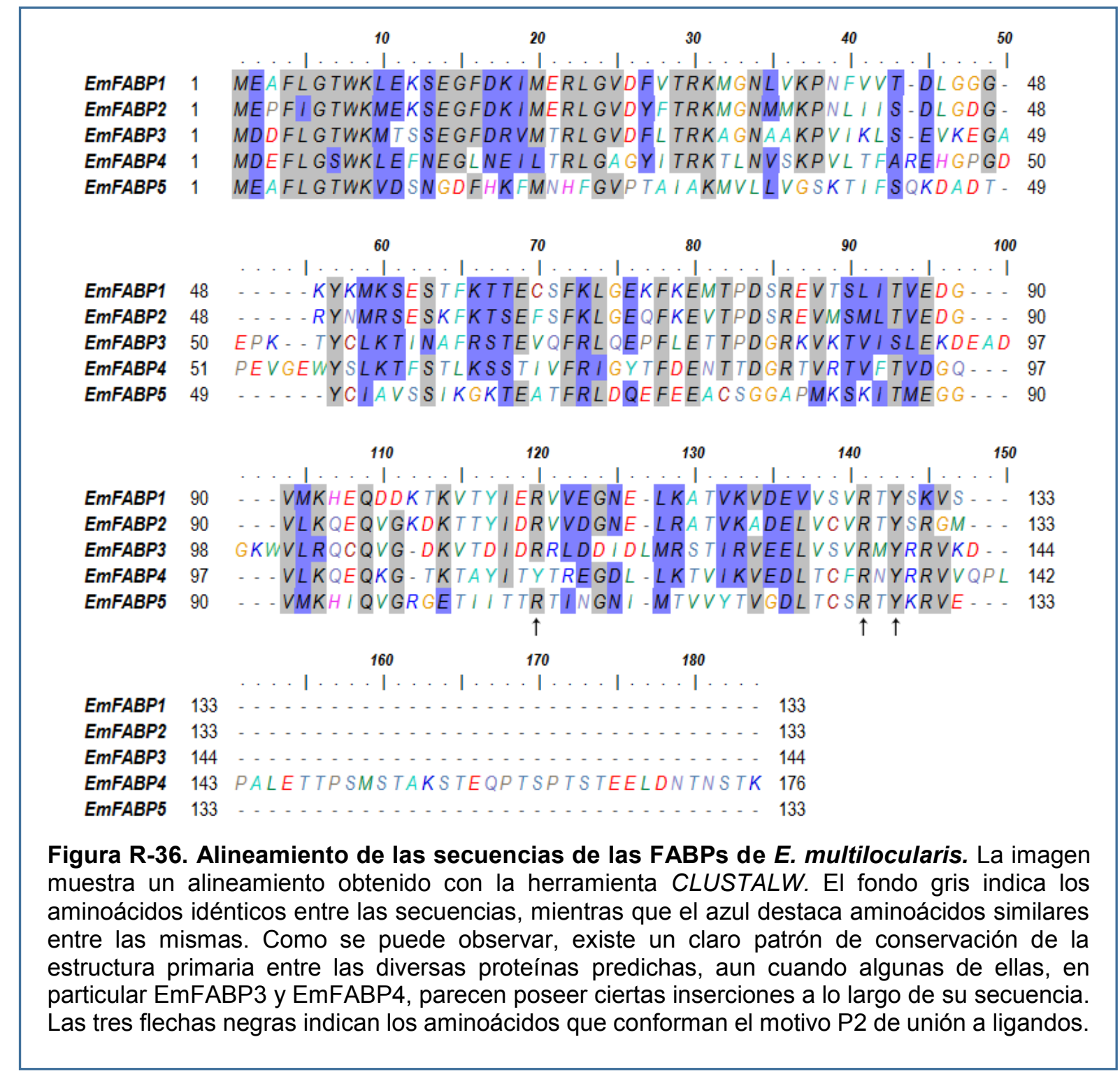

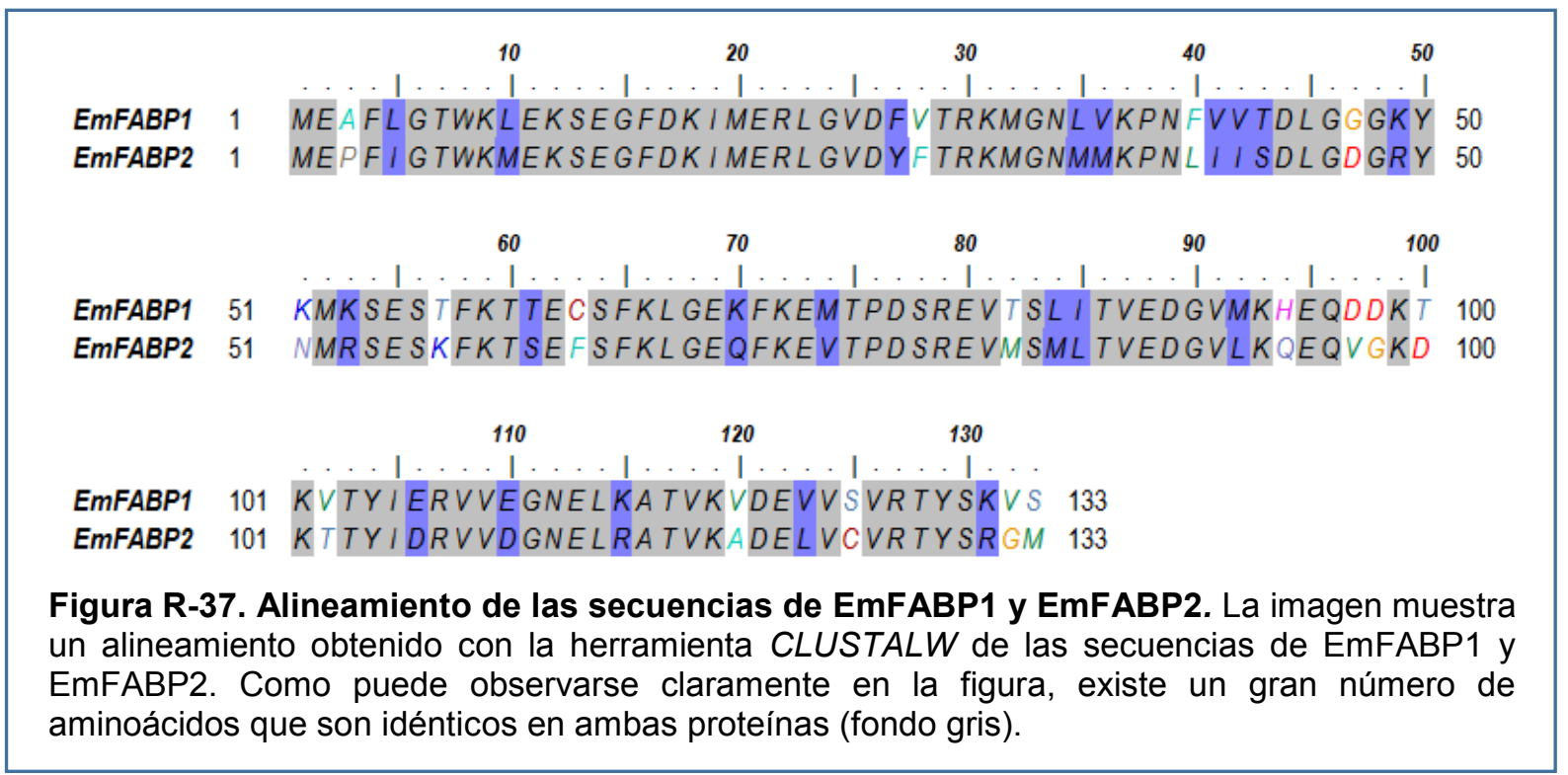




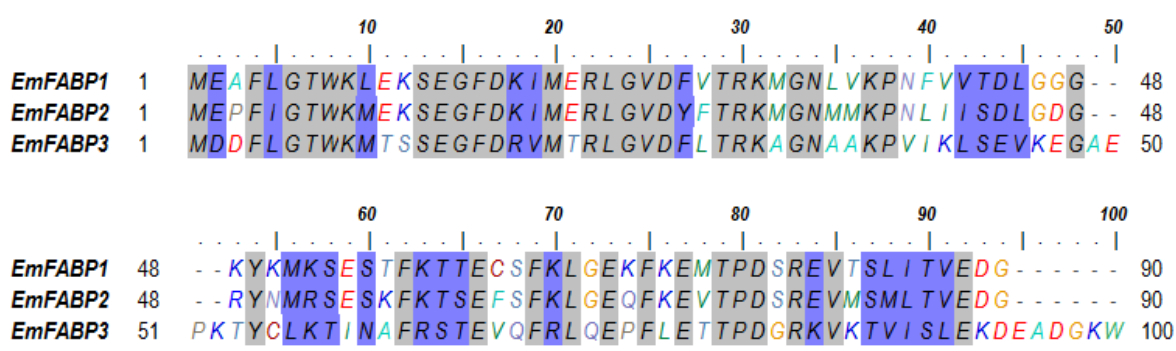

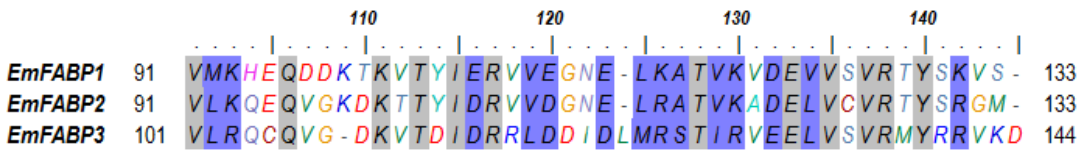

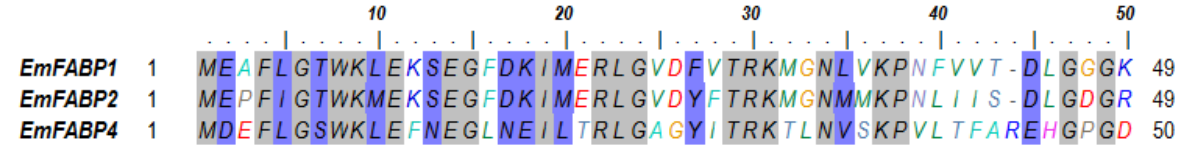

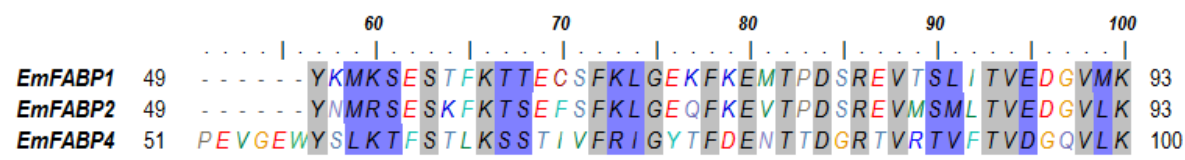

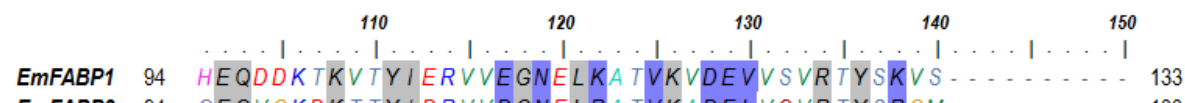
EmFABP2 $94 \quad$ QEQVGKDKTTYIDRVVDGNELRATVKADELVCVRTYSRGM . . . . . . . . 133 EmFABP4 101 QEQKG-TKTAYITYTREGDLLKTVIKVEDLTCFRNYRRVVQPLPALETTP 149

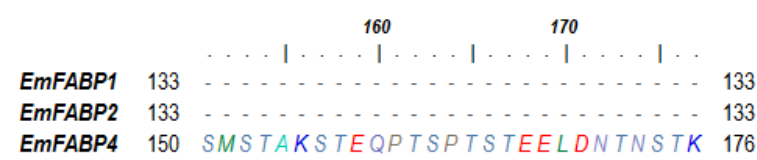

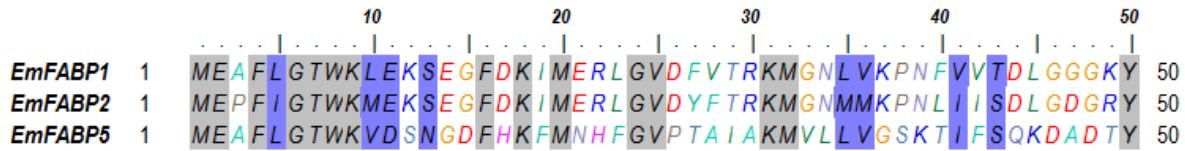

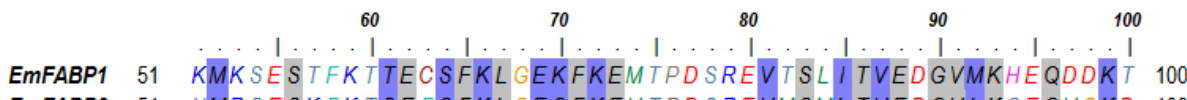
EmFABP2 51 NMRSESKFKTSEFSFKL GEQFKEVTPDSREVMSMLTVEDGVLKQEQVGKD 100 EmFABP5 51 CIIAVSSIKGKTEATFRLDQEFEEACSGGAPMKSKITMEGGVMKHIQVGRG 100

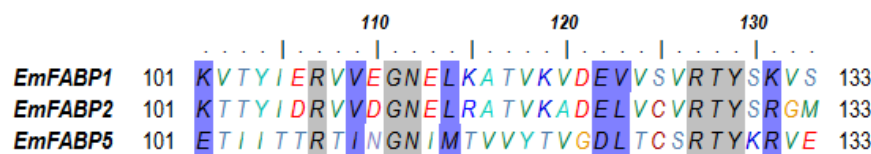

Figura R-38. Alineamiento de las secuencias de EmFABP1 y EmFABP2 con cada una de las demás FABPs. La imagen muestra un alineamiento obtenido con la herramienta CLUSTALW de las secuencias de EmFABP1 y EmFABP2 comparadas con EmFABP3, EmFABP4 y EmFABP5 por separado. Se puede observar que, aun cuando EmFABP3 y EmFABP4 poseen ciertas inserciones en la secuencia, poseen muchos aminoácidos en común con EmFABP1 y EmFABP2 (ya sea idénticos o similares). EmFABP5, por su parte, mantiene varios de los aminoácidos importantes sin variaciones, como podrían ser los involucrados en el motivo P2, aunque varía algo más en otras regiones. 
Con la finalidad de comparar las secuencias de las EmFABPs con las de proteínas de otras especies se realizaron análisis por BLASTP con las bases de datos del NCBI. Por un lado, se compararon las secuencias con la base de datos de proteínas, excluyendo las que fueran del género Echinococcus (Ver Tabla R-4). Por otra parte, se compararon con proteínas de mamíferos, para analizar a cuál de los subgrupos de FABPs se podrían asignar las de $E$. multilocularis (Ver Tabla R-5). En ambos casos, se tuvieron en cuenta sólo las entradas que correspondían a proteínas cuya existencia ha sido confirmada al menos a nivel de estructura primaria. Se descartaron las coincidencias con proteínas predichas y con construcciones artificiales.

\begin{tabular}{|c|c|c|c|c|c|}
\hline FABP E. multilocularis & FABP más semejante & Especie & Cobertura & Identidad & Código de acceso \\
\hline EmFABP1 & TpFABP & Taenia pisiformis & $100 \%$ & $80 \%$ & $\mathrm{gb}|A D Q 55925.1|$ \\
\hline EmFABP2 & fatty acid binding protein 2 & Taenia solium & $100 \%$ & $96 \%$ & $\mathrm{gb}|\mathrm{AFS} 64570.1|$ \\
\hline EmFABP3 & fatty acids and retinol binding protein isoform 2 & Taenia solium & $93 \%$ & $87 \%$ & $\mathrm{gb}|A D Z 72849.1|$ \\
\hline EmFABP4 & FABPa & Mesocestoides vogae & $78 \%$ & $41 \%$ & $\mathrm{gb}|\mathrm{ABO} 03626.3|$ \\
\hline EmFABP5 & TpFABP & Taenia pisiformis & $99 \%$ & $39 \%$ & gb|ADQ55925.1| \\
\hline
\end{tabular}

Tabla R-4. Comparación de secuencias de las FABPs de E. multilocularis con la base de datos de proteínas del NCBI. Se muestran las entradas que mostraron mayor semejanza en los alineamientos. No se tuvieron en cuenta las proteínas del género Echinococcus ni las que fueran predichas o construcciones artificiales.

\begin{tabular}{|c|c|c|c|c|c|}
\hline FABP E. multilocularis & FABP más semejante en mamiferos & Especie & Cobertura & Identidad & Código de acceso \\
\hline EmFABP1 & A-FABP & Rattus norvegicus (Rata) & $97 \%$ & $45 \%$ & NP_445817.1 \\
\hline EmFABP2 & $\mathrm{mP2}$ & Oryctolagus cuniculus (Conejo) & $96 \%$ & $47 \%$ & NP_001075699.1 \\
\hline EmFABP3 & $\mathrm{mP2}$ & Homo sapiens (Humano) & $97 \%$ & $38 \%$ & PDB: 3NR3_A \\
\hline EmFABP4 & A-FABP & Rattus norvegicus (Rata) & $77 \%$ & $34 \%$ & AAH84721.1 \\
\hline EmFABP5 & $\mathrm{mP2}$ & Bos taurus (Vaca) & $96 \%$ & $35 \%$ & 1 PMP_A \\
\hline
\end{tabular}

Tabla R-5. Comparación de secuencias de las FABPs de E. multilocularis con la base de datos de proteínas de mamíferos del NCBI. Se muestran las entradas que mostraron mayor semejanza en los alineamientos. No se tuvieron en cuenta las proteínas predichas.

Como se puede ver a partir de las tablas, las mayores coincidencias se dan con FABPs de cestodos y en particular, de cestodos tenioides, a excepción de EmFABP4. Cabe destacar que los genomas de dichos organismos son muy recientes (y en algunos, ni siquiera están disponibles) por lo que tal vez en el corto plazo puedan surgir nuevas variantes de FABPs. Es más, dada la relación filogenética tan cercana entre los géneros Echinococcus y Taenia, es probable que cada FABP de un organismo de un género posea su ortólogo correspondiente en el otro. El hecho de que EmFABP3 se asemeje a una proteína de $T$. solium que se ha reportado que es capaz de unir retinol (Kim et al., 2012), lleva a pensar que la existencia de numerosas FABPs en cestodos tal vez implique que cada una de ellas posee un espectro de 
ligandos más acotados, y funciones propias y específicas; al contrario de lo que previamente se pensaba (Esteves \& Ehrlich, 2006).

Al comparar las FABPs de E. multilocularis con las FABPs de mamíferos, se puede notar que todas ellas se asemejan a FABPs del subgrupo IV (Smathers \& Petersen, 2011), que incluye, entre otras, a H-FABP, A-FABP y $\mathrm{mP} 2$, lo cual coincide con lo previamente observado (Esteves \& Ehrlich, 2006).

\subsubsection{Caracterización bioinformática de los genes de las FABPs de $E$. multilocularis}

Como parte de los análisis de las secuencias predichas y clonadas de las diferentes FABPs de E. multilocularis se procedió a analizar la estructura génica de dichas secuencias. Tal como se mencionó previamente, las secuencias analizadas no son estrictamente los genes completos de las FABPs propuestas, ya que no se posee información sobre los extremos 5' ni 3' UTR (del inglés untranslated region, es decir, región no traducida) ni sobre regiones regulatorias como pueden ser las secuencias promotoras; sino que corresponden a las regiones genómicas comprendidas entre el codón de iniciación y el codón de finalización de la traducción, determinados a partir de las predicciones y del clonado de las CDS.

Mediante la herramienta bioinformática Splign se alinearon las CDS y las secuencias genómicas respectivas para cada una de las FABPs. De esa manera, se localizaron correctamente los sitios de splicing de cada uno de los genes, así como las bases en los extremos 5' y 3' de los intrones (Ver Tabla R-6). A excepción del intrón I de emfabp5, todos los otros intrones poseen las típicas secuencias GT en el extremo 5' y AG en el 3'. El intrón I de emfabp5 posee en el extremo 5' la secuencia GC, que si bien es menos común que la secuencia GT, se sabe que se presenta en algunos intrones de varias especies diferentes,

\begin{tabular}{|c|c|c|c|}
\cline { 2 - 4 } \multicolumn{1}{c|}{} & Posición Intrón/es (aa) & Tamaño Intrón/es $(\mathrm{pb})$ & Estructura Génica \\
\hline EmFABP1 & 116 & 80 & $<$ <xón>GT...AG<Exón> \\
\hline EmFABP2 & 116 & 80 & $<$ <xón>GT...AG<Exón> \\
\hline EmFABP3 & 126 & 4443 & $<$ <xón>GT...AG<Exón> \\
\hline EmFABP4 & 122 & 2617 & <Exón>GT...AG<Exón> \\
\hline EmFABP5 & $82 / 116$ & $434 / 291$ & <Exón>GC...AG<Exón>GT...AG<Exón> \\
\hline
\end{tabular}

Tabla R-6. Posición y tamaño de los intrones en las diferentes EmFABPs. En la tabla se resume la posición de los intrones (en relación a la secuencia de aminoácidos de las proteínas codificadas), el tamaño de los intrones (en pares de bases) y la estructura de los genes de las diferentes FABPs, destacándose las bases de los extremos de los intrones. 
entre las cuales se hallan los humanos, C. elegans y Arabidopsis thaliana (Parada et al., 2014; Sheth et al., 2006). Por otra parte, la distribución de los intrones (Ver Figura R-39) coincide con lo observado previamente en FABPs de invertebrados, en el sentido de que, si bien el número y el tamaño de los intrones son variables, la posición de los mismos se conserva incluso en relación a las posiciones altamente conservadas de los intrones en las FABPs de vertebrados (Bernlohr et al., 1997; Esteves \& Ehrlich, 2006; Smathers \& Petersen, 2011; Zimmerman \& Veerkamp, 2002). Es llamativo que sólo emfabp5 posea dos intrones, aunque se ha visto, por ejemplo en $C$. elegans, que genes de diferentes FABPs poseen un número diferente de intrones (Esteves \& Ehrlich, 2006).

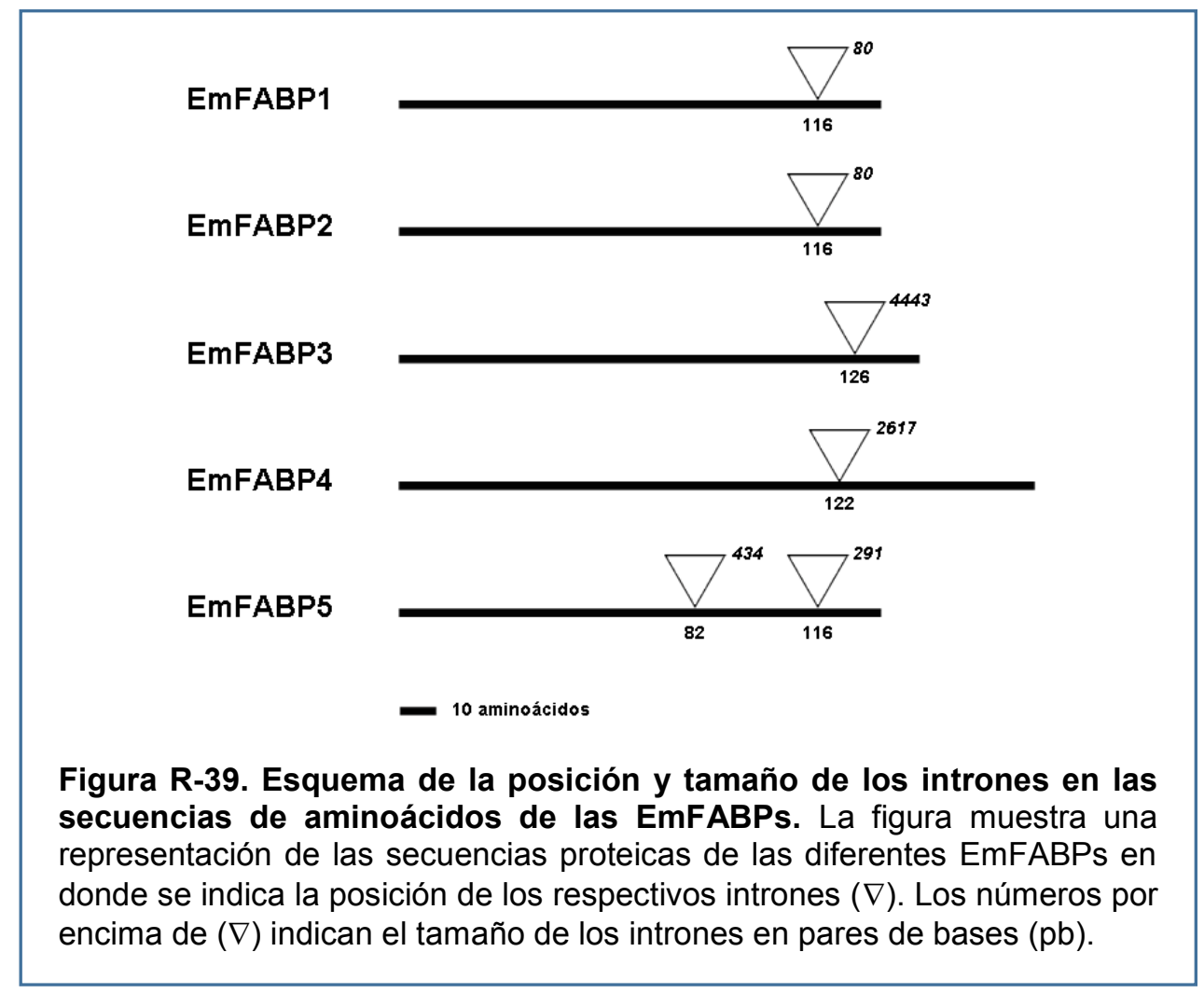

Posteriormente, se analizó también la ubicación de los genes de las diferentes EmFABPs en el genoma de E. multilocularis. Dicho análisis ubicó a los genes para EmFABP1, EmFABP2, EmFABP3 y EmFABP4 en el cromosoma 7 de E. multilocularis, mientras que el gen de EmFABP5 se localiza en el cromosoma 4. Todas las proteínas del cromosoma 7 se encuentran codificadas en una misma hebra, salvo EmFABP3 que está codificada sobre la complementaria (Ver Figuras R-40 y R-41). 

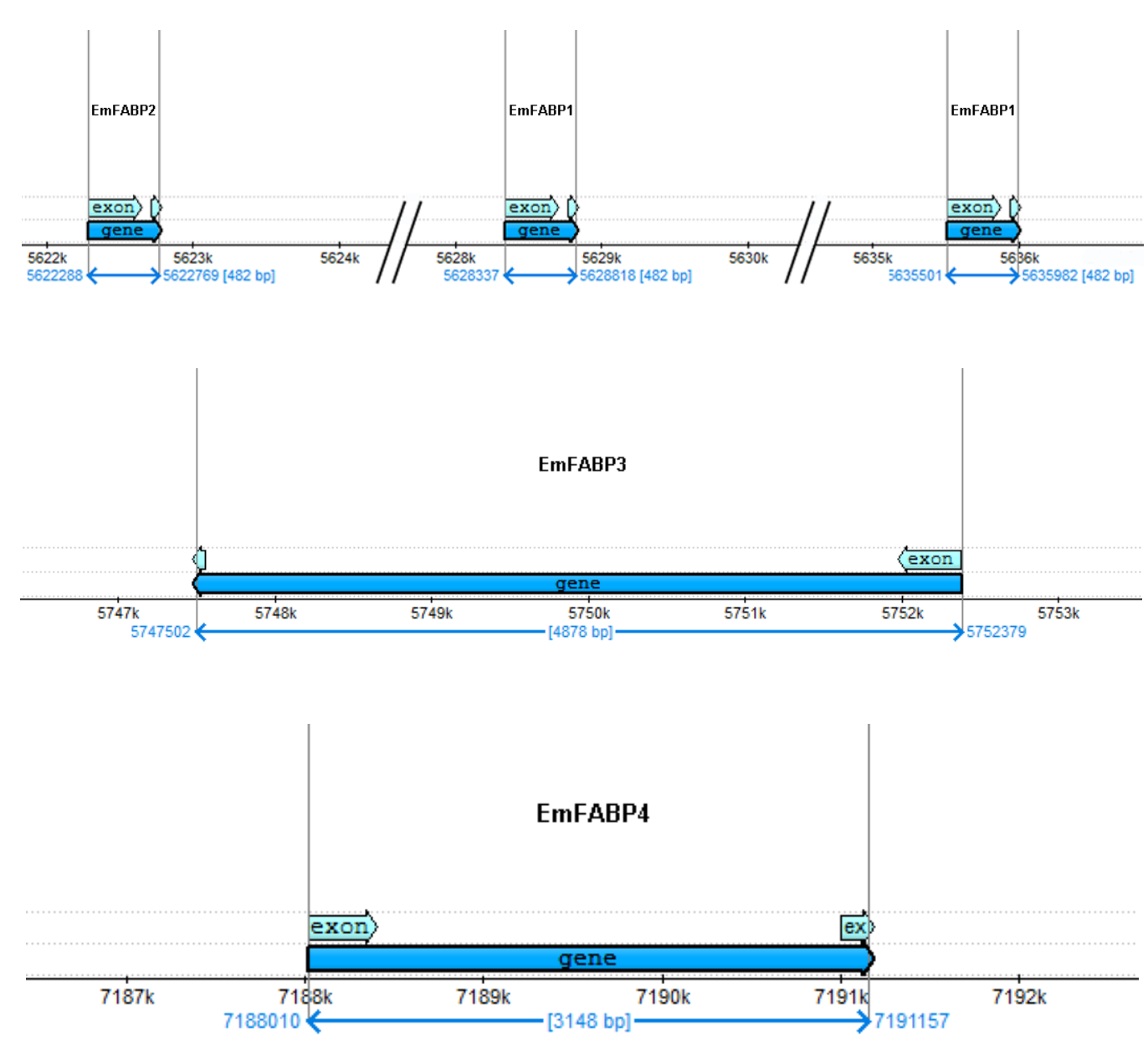

Figura R-40. Esquema de la posición de los genes emfabp1-4 en el cromosoma 7 de $E$. multilocularis. La figura muestra la ubicación relativa de los diferentes genes a lo largo del cromosoma 7 de E. multilocularis. Como se puede observar, tanto EmFABP2, EmFABP4 como ambas copias de EmFABP1 se encuentran codificadas en una misma hebra, mientras que EmFABP3 está codificada en la otra. Las dos copias de EmFABP1 corresponden, de izquierda a derecha, a las entradas EmuJ_002165500 y EmuJ_000550000 del GeneDB.

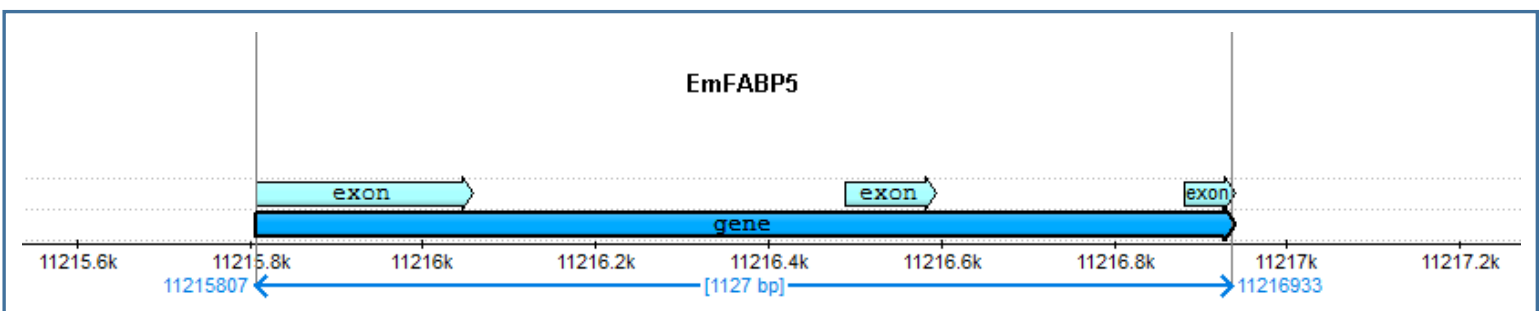

Figura R-41. Esquema de la posición del gen emfabp5 en el cromosoma 4 de $E$. multilocularis. La figura muestra la ubicación del gen emfabp5 con sus respectivos exones, localizado en la hebra directa del cromosoma 4 de E. multilocularis.

Cabe destacar que a continuación del gen emfabp2 se encuentran dos copias del gen emfabp1. Esto había sido observado al analizar versiones previas del genoma de $E$. multilocularis, pero se había atribuido a un error de ensamblaje del mismo. No obstante, dicha distribución se conserva en las versiones actuales, más curadas, del genoma; y al analizar las 
secuencias flanqueantes de ambos genes se observa que las mismas son diferentes. Río arriba del codón de inicio, ambas secuencias comparte unas 600 bases idénticas, pero luego varían ampliamente. En cuanto a las secuencias río abajo, conservan algunas regiones similares, pero se diferencian bastante una de la otra (Ver Figuras $R-42 A$ y $R-42 B$ ). Si bien se requieren otros estudios para analizar si ambas secuencias se transcriben, el hecho de que las secuencias flanqueantes sean diferentes podría tener algún tipo de implicancia en la regulación post-transcripcional de dichos genes, ya que es en esas secuencias ( 3 ' UTR en particular) en donde se unen moléculas de ARN regulatorias, como los microRNAs (o miRNAs). Estas moléculas de ARN de 22 nucleótidos regulan la expresión génica induciendo la destrucción de los mRNA, modificando su estabilidad o regulando la traducción de los mismos. En Echinococcus spp. se ha descripto la existencia de miRNAs y sus vías de procesamiento (Bai et al., 2014; Cucher et al., 2015, 2011; Fromm et al., 2013; Jin et al., 2013; Zheng, 2013).

El hecho de que tres genes para FABPs se encuentren formando un cluster en el genoma de E. multilocularis, no es tan sorprendente si se tiene en cuenta que situaciones similares se han reportado ya en varios organismos. En el caso de humanos, por ejemplo, se ha observado que A-FABP, E-FABP, mP2, T-FABP y la recientemente reportada FABP12, se encuentran codificadas no sólo en un mismo cromosoma sino dentro de una región de unos 300000 pares de bases (Smathers \& Petersen, 2011). 


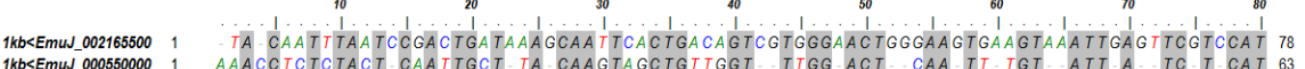

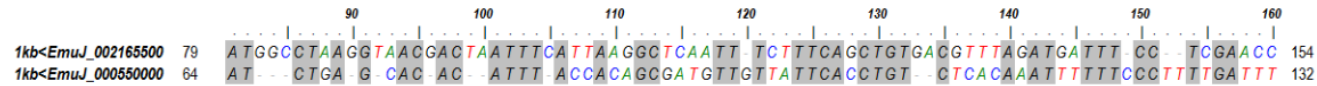
$\begin{array}{rlllllll}170 & 180 & 190 & 200 & 210 & 220 & 230 & 240\end{array}$ 1 1kb EmuJ 002165500 155 GA CGCCCAGAC I A AGTGCGACACTGGCAGTACCAA AACGA CTC GCTCACCACTG CAAGGTCTCAG 218 $1 \mathrm{~kb}<$ EmuJ_000550000 133 AATCTCTCAGTCGTTTTATTTIGATAAAATTTGTTIATTAATTTGGACCCTCATGAGCAGTATTGATATGAAG CTGAT 211

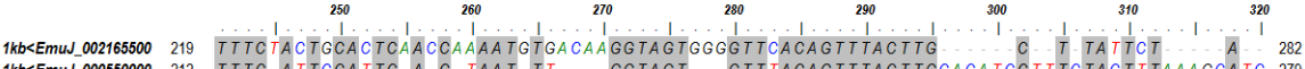

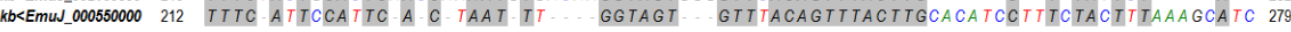

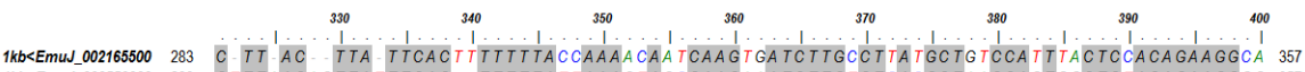

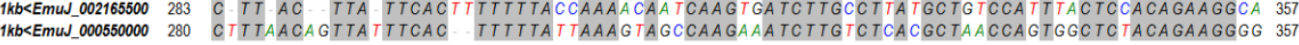

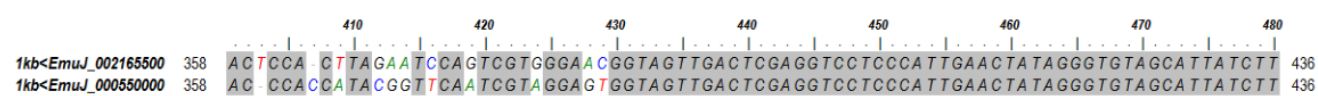

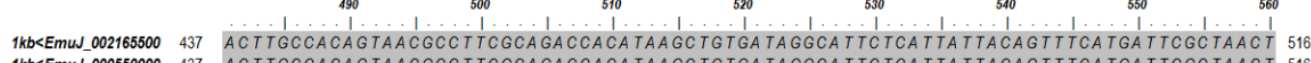
1 1kb<Emu__000550000 437 ACTTGCCACAGTAACGCCTTCGCAGACCACATAAGCTGTGATAGGCATTCTCATTATTACAGTTTCATGATTCGCTAACT 516

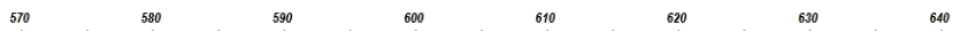

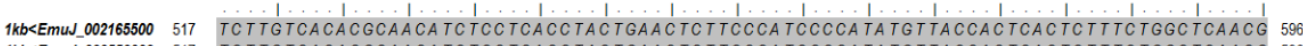
1kb<EmuJ_000550000 517 TCT TGTCACACGCAACA TCTCCTCACCTACTGAACTCT TCCCATCCCCATATGT TACCACTCACTCTTTCTGGCTCAACG 590

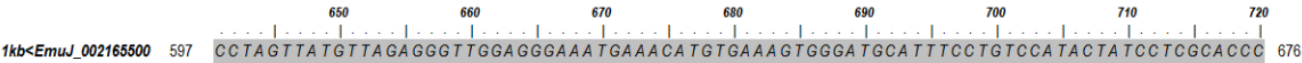
1kb<EmuJ 000550000597 CCTAGTTATGTTAGAGGGTTGGAGGGAAATGAAACATGTGAAAGTGGGATGCATTTCCTGTCCATACTATCCTCGCACCC 676

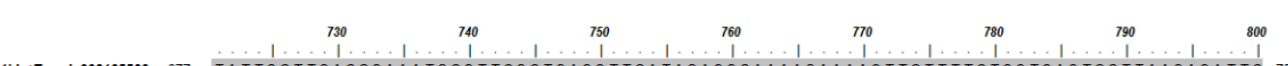

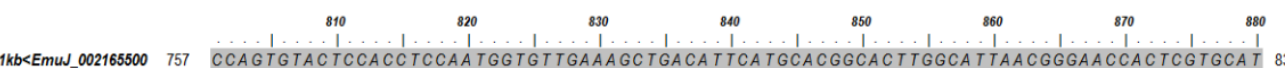
$1 \mathrm{~kb}<$ EmuJ_000550000 757 CCAGTGTACTCCACCTCCAATGGTGTTGAAAGCTGACATTCATGCACGGCACTTGGCATTAACGGGAACCACTCGTGCAT 836

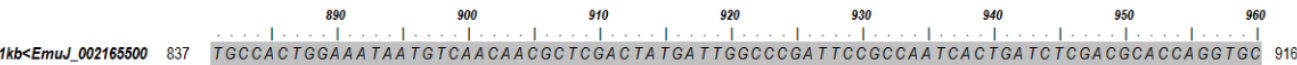
1kb<EmuJ_000550000 837 TGCCACTGGAATAATGTCAACAACGCTCGACTATGATTGGCCCGATTCCGCCAATCACTGATCTCGACGCACCAGGTGC 916

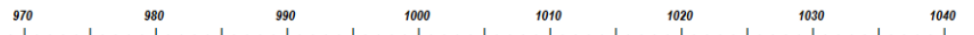
1kb<EmuJ_002165500 917 ACGCGTCCGTAGTTGATATATGGTGGGATGGATGTGGCAAAAGTCAGAGCCTCAGCCACACGTAGGATCGGGTAGTTGTC 996 1kb<EmuJ_000550000 917 ACGCGTCCGTAGTTGATATATGGTGGGATGGATGTGGCAAAAGTCAGAGCCTCAGCCACACGTAGGATCGGGTAGTTGTC 996

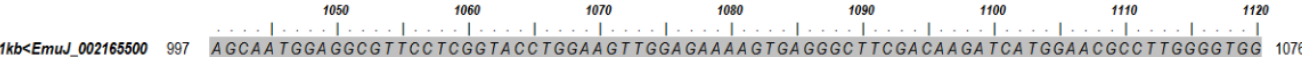

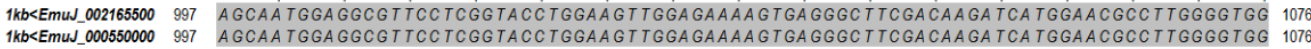
\begin{tabular}{llllllll}
\hline 1130 & 1140 & 1150 & 1160 & 1170 & 1180 & 1190 & 1200
\end{tabular}

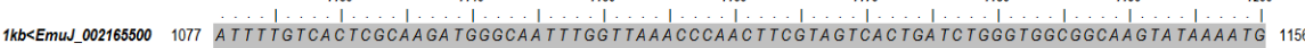
1kb<EmuJ_000550000 1077 ATTTTGTCACTCGCAAGATGGGCAATTTGGTTAAACCCAACTTCGTAGTCACTGATCTGGGTGGCGGCAAGTATAAAATG 1156

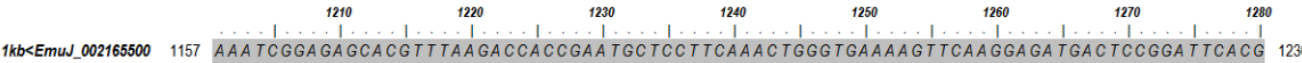
1kb<EmuJ_000550000 1157 AAATCGGAGAGCACGTTTAAGACCACCGAATGCTCCTTCAAACTGGGTGAAAAGTTCAAGGAGATGACTCCGGATTCACG 123

$1290 \quad 1300 \quad 1310 \quad 1320 \quad 1330 \quad 1340 \quad 1350 \quad 1360$

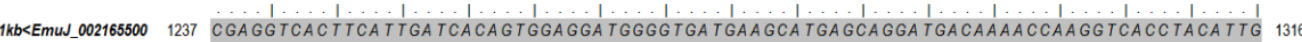

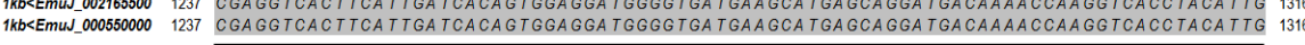

$1370 \quad 1380 \quad 1390 \quad 1400 \quad 1410 \quad 1420 \quad 1430 \quad 1440$

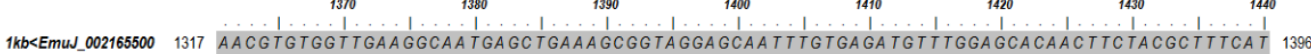

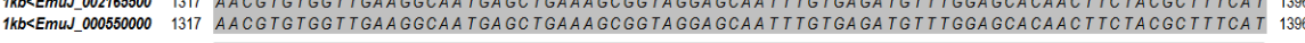

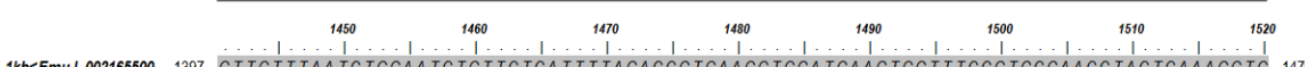

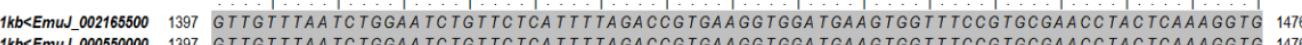
1477 TCGTAA 1402 1kb<emuJ_002165500 1477 TCGTAA 14

Figura R-42A. Alineamiento de las dos copias de EmFABP1 en el genoma de $E$. multilocularis. En la figura se muestran las secuencias de las dos copias de EmFABP1 incluyendo los 1000 pares previos al codón de inicio. Se marca con una línea negra la región entre el ATG y el codón de terminación. 


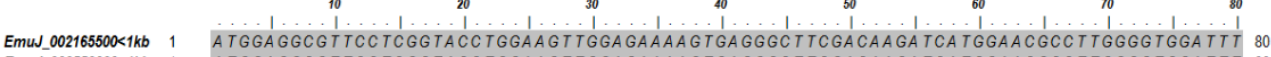
EmuJ_000550000<1kb 1 ATGGAGGCGTTCCTCGGTACCTGGAAGTTGGAGAAAAGTGAGGGCTTCGACAAGATCATGGAACGCCTTGGGGTGGATTT 80

$\begin{array}{ccccccccc} & 90 & 100 & 110 & 120 & 130 & 140 & 150 & 160 \\ \text { EmuJ_002165500<1kb } & 81 & \text { TGTCACTCGCAAGATGGGCAATTTGGTTAAACCCAACTTCGTAGTCACTGATCTGGGTGGCGGCAAGTATAAAATGAAAT } & 160\end{array}$

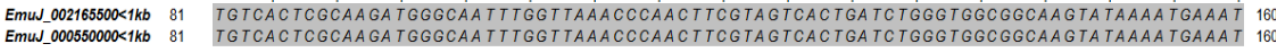
\begin{tabular}{rlllllll}
\hline 170 & 180 & 190 & 200 & 210 & 220 & 230 & 240
\end{tabular} EmuJ_002165500<1kb 161 CGGAGAGCACGTTTAAGACCACCGAATGCTCCTTCAAACTGGGTGAAAGTICAAGGAGATGACTCCGGATTCACGCGAG 240

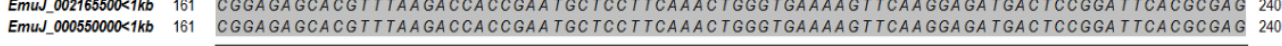

$$
250 \quad 260 \quad 270 \quad 280 \quad 290 \quad 300 \quad 310 \quad 320
$$

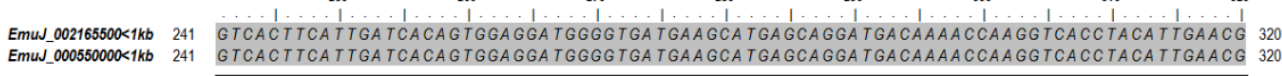

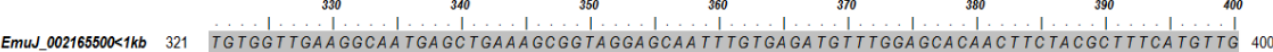

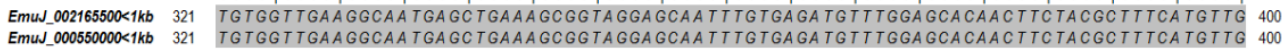

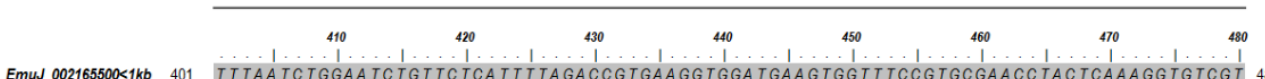

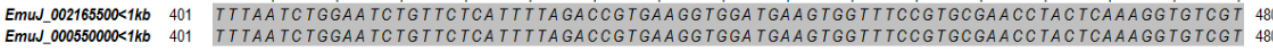
$\begin{array}{ccccccccc} & 490 & 500 & 510 & 520 & 530 & 540 & 550 & 560 \\ \text { EmuJ_002165500<1kb } & 481 & \text { AAGAGAGGGTCTCATTTTCTCAG TACTTTCCTCCTCTACTTIATCACTCCCACGCCTTTCTCTTCCTTTCCAG CATGCT } & 155\end{array}$

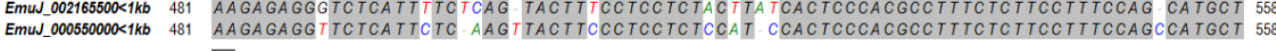

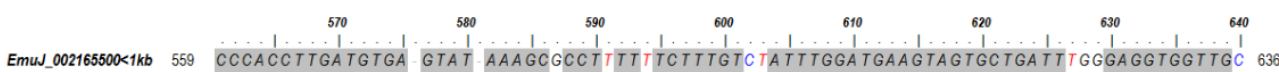

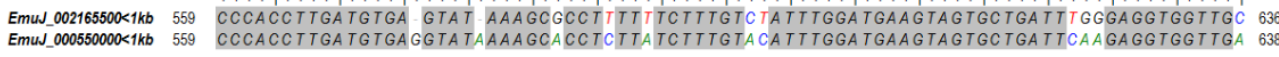

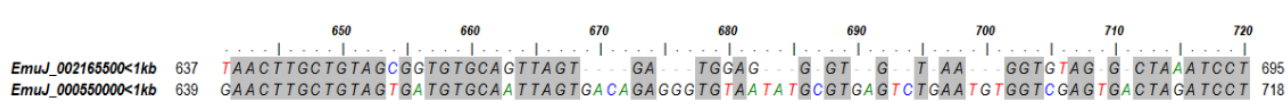

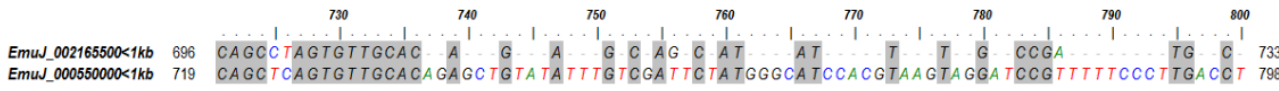

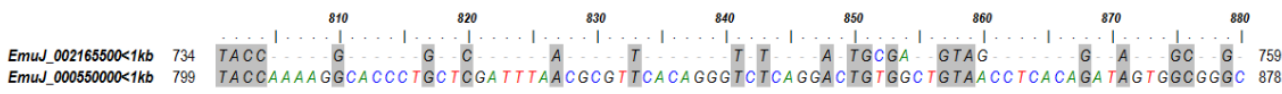

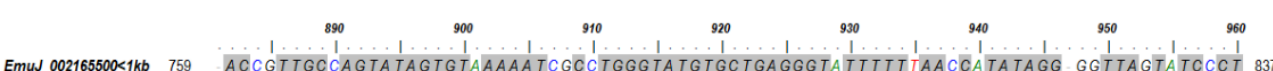

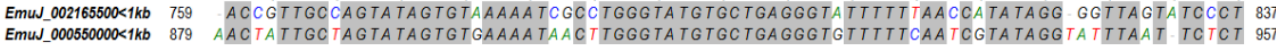

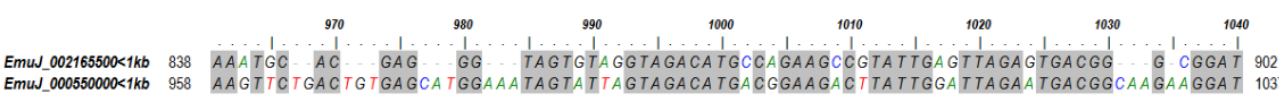

$$
1050 \quad 1060 \quad 1070 \quad 1080 \quad 1090 \quad 1100 \quad 1110 \quad 1120
$$

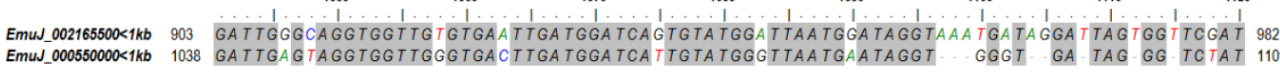

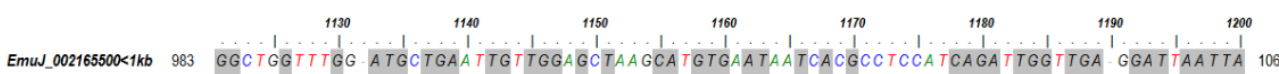

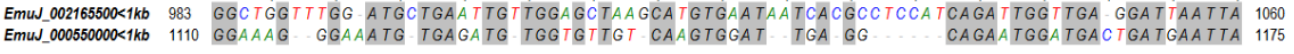

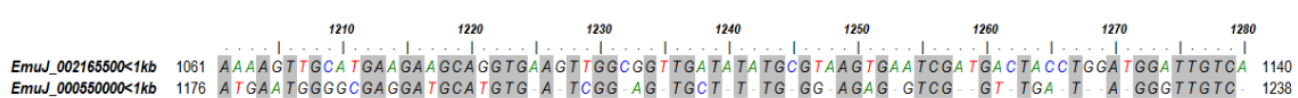

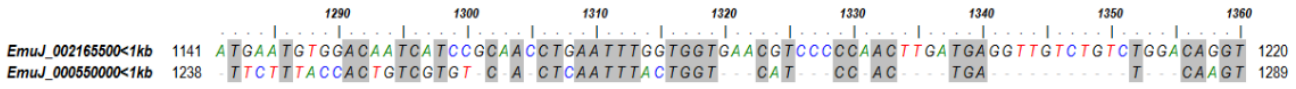

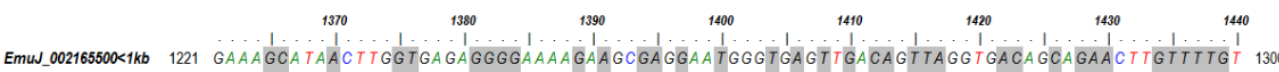

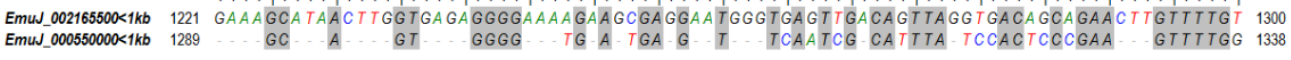

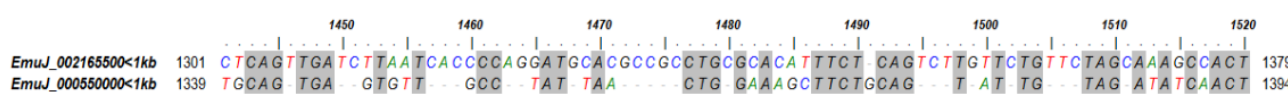

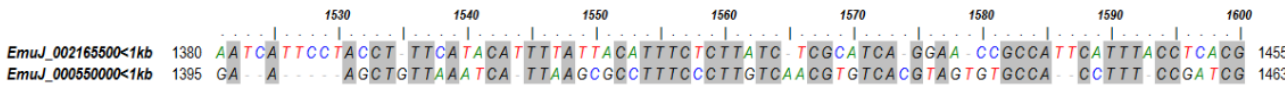

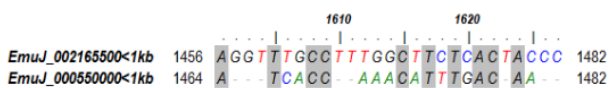

Figura R-42B. Alineamiento de las dos copias de EmFABP1 en el genoma de $E$. multilocularis. En la figura se muestran las secuencias de las dos copias de EmFABP1 incluyendo los 1000 pares de bases posteriores al codón de terminación. Se marca con una línea negra la región entre el ATG y el codón de terminación. 


\subsubsection{Predicción de FABPs en E. granulosus y comparación con las FABPs de E. multilocularis}

Con el objetivo de analizar si en E. granulosus era posible encontrar los genes ortólogos a los de las FABPs de E. multilocularis, se realizaron búsquedas en la base de datos GeneDB, del Wellcome Trust Sanger Institute y se analizaron las secuencias genómicas de la versión “Egranulosus_genome_v3". En la Tabla $R$-7 se puede observar un resumen de lo encontrado en el genoma de E. granulosus.

\begin{tabular}{|c|c|c|c|c|c|}
\hline Nombre & Nombre Sistemático GeneDB & Longitud Gen $(\mathrm{pb})^{(\mathrm{a})}$ & Longitud CDS (pb) & Exones & Longitud Proteina (aa) \\
\hline EgFABP1 & EgrG_000549850 (b) & 482 & 402 & 2 & 133 \\
\hline EgFABP1.2 & EgrG_000550000 & 482 & 402 & 2 & 133 \\
\hline EgFABP2 & EgrG_000549800 & 482 & 402 & 2 & 133 \\
\hline EgFABP3 & EgrG_000551000 & 4897 & 435 & 2 & 144 \\
\hline EgFABP4 & EgrG_000417200 & 3185 & 531 & 2 & 176 \\
\hline EgFABP5 & - & 1126 & 402 & 3 & 133 \\
\hline
\end{tabular}

Tabla R-7. Datos de las secuencias predichas para FABPs en E. granulosus. La tabla muestra algunas características de las secuencias predichas. Los nombres sistemáticos corresponden al genoma disponible en http://www.genedb.org/ (Wellcome Trust Sanger Institute).

(a) Se consideran las secuencias genómicas comprendidas entre el codón de inicio y el codón de terminación de la transcripción de las proteínas predichas.

(b) En GeneDB se encuentra mal anotado el gen de EgFABP1 bajo el código de acceso presentado en la tabla.

Como se puede observar en la Tabla R-7, las secuencias encontradas en E. granulosus se asemejan en varios aspectos a las predichas en $E$. multilocularis, aunque difieren en otros. Quizás lo más llamativo es el hecho de que en el caso de E. granulosus, el cluster de tres genes contiguos de FABPs no posee dos copias exactamente iguales de egfabp1, sino que una pareciera ser una variante diferente (Ver Figura $R-43$ ). Dada la ubicación relativa de dicho gen, comparable a una de las copias de emfabp1 (Ver más adelante), se lo denominó egfabp1.2.

El hecho de que EgFABP1.2 no conserve dos de los tres aminoácidos que forman parte del motivo P2 de unión a ligandos hace pensar que dicha proteína, en caso de expresarse, podría unir los ligandos de otra manera, o bien unir otro tipo de ligandos diferentes a los que une EgFABP1.

Se analizó también la similitud de secuencias dentro de la familia de las FABPs de $E$. granulosus, tal como se realizó para las FABPs de E. multilocularis. Como se puede observar en la Tabla $R-8$, las similitudes entre las diferentes FABPs se asemeja a lo observado con los genes ortólogos, de E. multilocularis. Asimismo, cabe destacar que la CDS de egfabp1.2 se 
asemeja casi tanto a la de egfabp1 como egfabp2, mientras que a nivel proteico EgFABP2 se parece más que EgFABP1.2 a EgFABP1.

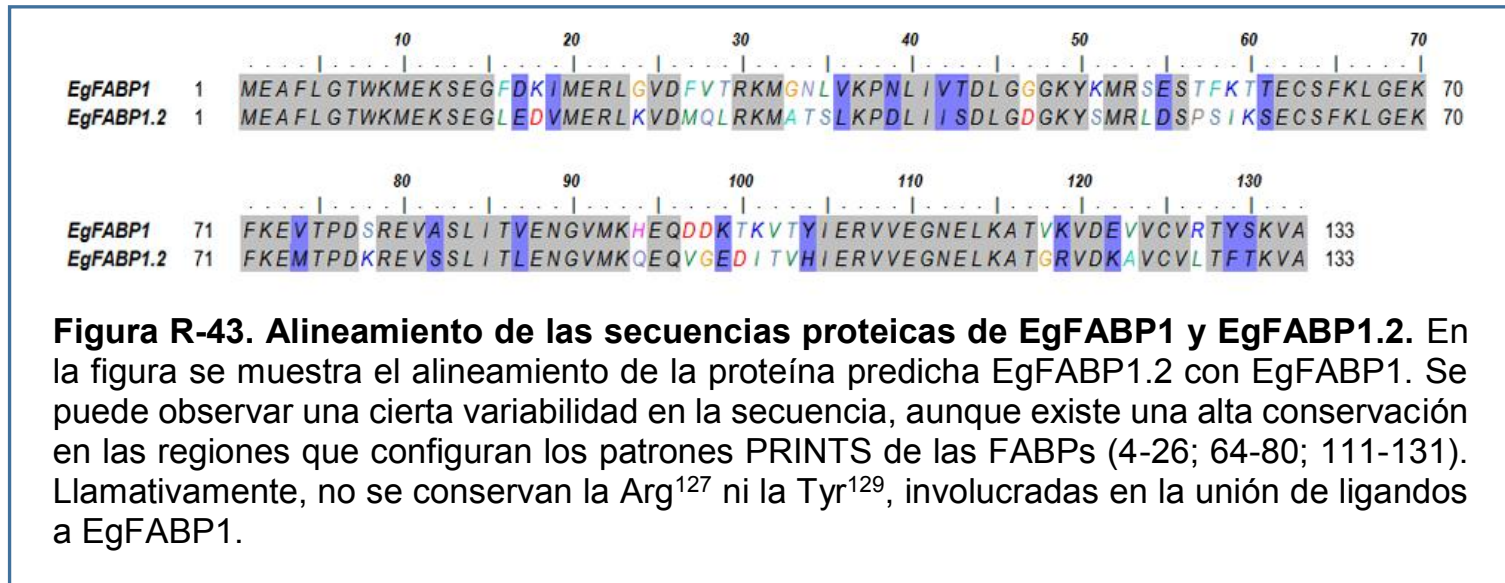

Por otra parte, con la finalidad de comparar las secuencias de las FABPs de ambos cestodos, se realizaron alineamientos de las secuencias proteicas predichas para cada una de las FABPs y comparaciones del grado de similitud de las mismas. Como se puede observar en la Figura $R-44$ y en la Tabla $R-9$, el grado de conservación es notable, y muestra la estrecha relación filogenética entre E. multilocularis y E. granulosus. Asimismo, refleja lo observado previamente en otros organismos, en donde se asemejan más las FABPs de un mismo órgano o tejido de distintos organismos, que las diferentes FABPs de distintos tejidos de un mismo organismo (Zimmerman \& Veerkamp, 2002). La excepción parece ser EgFABP1.2, que no tendría un equivalente directo en E. multilocularis. Como se mencionó anteriormente, y se mostrará a continuación, la posición equivalente a la de egfabp1.2, en el genoma de $E$. multilocularis, es ocupada por una copia exacta de emfabp1.

\begin{tabular}{|c|c|c|c|c|c|c|}
\cline { 2 - 7 } \multicolumn{1}{c|}{} & EgFABP1 & EgFABP1.2 & EgFABP2 & EgFABP3 & EgFABP4 & EgFABP5 \\
\hline EgFABP1 & & $81,3 \%$ & $83,6 \%$ & $40,0 \%$ & $28,8 \%$ & $51,2 \%$ \\
\hline EgFABP1.2 & $\mathbf{6 6 , 4} \% / 79,8 \%$ & & $74,6 \%$ & $37,9 \%$ & $27,9 \%$ & $48,0 \%$ \\
\hline EgFABP2 & $\mathbf{7 4 , 6} \% / 88,8 \%$ & $\mathbf{6 1 , 7} \% / 80,4 \%$ & & $39,1 \%$ & $27,7 \%$ & $49,3 \%$ \\
\hline EgFABP3 & $\mathbf{2 3 , 6 \% / 4 2 , 4 \%}$ & $\mathbf{2 0 , 1} \% / 37,5 \%$ & $\mathbf{2 4 , 3} \% / 41,7 \%$ & & $29,6 \%$ & $34,0 \%$ \\
\hline EgFABP4 & $\mathbf{1 5 , 9} \% / 27,3 \%$ & $\mathbf{1 3 , 5} \% / 25,0 \%$ & $\mathbf{1 4 , 8} \% / 26,1 \%$ & $\mathbf{1 4 , 8} \% / 32,9 \%$ & & $25,6 \%$ \\
\hline EgFABP5 & $\mathbf{3 5 , 1} \% / 48,5 \%$ & $\mathbf{3 1 , 3} \% / 47,0 \%$ & $\mathbf{3 1 , 3} \% / 48,5 \%$ & $\mathbf{1 4 , 6} \% / 22,2 \%$ & $\mathbf{8 , 5} \% / 19,9 \%$ & \\
\hline
\end{tabular}

Tabla R-8. Análisis de identidad de secuencias entre las diversas FABPs de $E$. granulosus. En la tabla se muestran los porcentajes de identidad de secuencia para las diversas FABPs. En la parte inferior de la diagonal (en negrita) se muestran los valores de similitud de secuencia a nivel proteico, siendo los valores en color negro los correspondientes a identidad de secuencia y los que están en azul, los de similitud. Por encima de la diagonal se encuentran los porcentajes de identidad de secuencia a nivel nucleotídico de las CDS correspondientes. 
Al analizar las posiciones de los genes en el genoma de $E$. granulosus, se encontró que los genes de EgFABP2, EgFABP1 y EgFABP1.2 se encontraban formando un cluster, y ocupando posiciones relativas similares a los de EmFABP2 y ambas copias de EmFABP1 (Ver Figura R-45). Por otra parte, el gen de EgFABP3 se encontró en el mismo scaffold (fragmento de cromosoma aún no ensamblado) codificado en la otra hebra, al igual que EmFABP3. La distancia entre el inicio de EgFABP2 y el de EgFABP3 (recordar que está sobre la hebra complementaria) es de $135088 \mathrm{pb}$, mientras que en E. multilocularis la distancia equivalente es de 130092pb. Estas cuatro FABPs se encontraron en el scaffold_007, EgFABP4 en el scaffold_019 y EgFABP5 en el scaffold_009.

\begin{tabular}{|c|c|c|c|c|c|c|}
\hline & EmFABP1 & $\operatorname{EmFABP}^{(\mathrm{b})}$ & EmFABP2 & EmFABP3 & EmFABP4 & EmFABP5 \\
\hline EgFABP1 & $92,5 \% / 97,8 \%$ & $92,5 \% / 97,8 \%$ & $74,6 \% / 88,8 \%$ & $23,6 \% / 42,4 \%$ & $15,9 \% / 27,3 \%$ & $34,3 \% / 49,3 \%$ \\
\hline EgFABP1.2 & $62,4 \% / 78,2 \%$ & $62,4 \% / 78,2 \%$ & $61,7 \% / 80,4 \%$ & $20,1 \% / 37,5 \%$ & $13,6 \% / 25,0 \%$ & $31,6 \% / 46,7 \%$ \\
\hline EgFABP2 & $71,4 \% / 87,2 \%$ & $71,4 \% / 87,2 \%$ & $100 \%$ & $24,3 \% / 41,7 \%$ & $14,8 \% / 26,1 \%$ & $31,6 \% / 48,9 \%$ \\
\hline EgFABP3 & $22,9 \% / 41,7 \%$ & $22,9 \% / 41,7 \%$ & $24,3 \% / 41,7 \%$ & $100 \%$ & $14,8 \% / 33,5 \%$ & $15,3 \% / 23,6 \%$ \\
\hline EgFABP4 & $16,5 \% / 27,3 \%$ & $16,5 \% / 27,3 \%$ & $14,8 \% / 26,1 \%$ & $14,8 \% / 33,0 \%$ & $96,6 \% / 97,7 \%$ & $9,1 \% / 19,9 \%$ \\
\hline EgFABP5 & $32,8 \% / 47,8 \%$ & $32,8 \% / 47,8 \%$ & $31,3 \% / 48,5 \%$ & $14,6 \% / 22,2 \%$ & $8,5 \% / 19,9 \%$ & $95,5 \% / 97,8 \%$ \\
\hline
\end{tabular}

Tabla R-9. Análisis de identidad de secuencias entre las FABPs de E. granulosus y E. multilocularis. En la tabla se muestran los porcentajes de identidad de secuencia para las diversas FABPs. Los valores en color negro corresponden al porcentaje de identidad de secuencia y los que están en azul, a los porcentajes de similitud. En la diagonal se encuentra la comparación entre ortólogos de E. granulosus y E. multilocularis.

(b) Corresponde a una de las copias de EmFABP1, que estaría codificada por el gen ortólogo al de EgFABP1.2

Durante el transcurso del presente trabajo de tesis fue publicado un trabajo en el que se realizó un análisis filogenético de diversas FABPs predichas a partir de datos genómicos de diferentes especies (Y. Zheng et al., 2013). En dicho trabajo, se propone la existencia de cinco loci correspondientes a genes de FABPs tanto en $E$. granulosus como en E. multilocularis. Se destaca que en $E$. multilocularis existen dos loci que codifican para una misma FABP, lo que coincide con lo observado y presentado en esta tesis. No obstante, en dicho trabajo se afirma que dos de los genes, en ambas especies, carecen de intrones. El análisis de las secuencias proteicas propuestas en dicho trabajo, y disponibles como material suplementario del mismo, mostró que dichas secuencias equivaldrían a las que hemos nombrado EgFABP3 y EgFABP4 (de E. granulosus), y EmFABP3 y EmFABP4 (de E. multilocularis). Los cinco loci por ellos propuestos serían los correspondientes a las FABPs 1, 2, 3 y 4 de cada cestodo, a lo que se suma una copia de EmFABP1 en el caso de E. multilocularis y lo que hemos denominado EgFABP1.2, en el caso de E. granulosus. El hecho de que se sostenga en dicho trabajo que las secuencias que codifican para las FABPs 3 y 4 carecen de intrones se debe a que no se 
tuvo en cuenta el sitio de splicing, y se consideraron codones que, en realidad, forman parte del intrón (Ver Figura R-46). Por otra parte, al evaluar las secuencias propuestas con la herramienta InterPro, se observa que aparecen sólo las dos primeras fingerprints

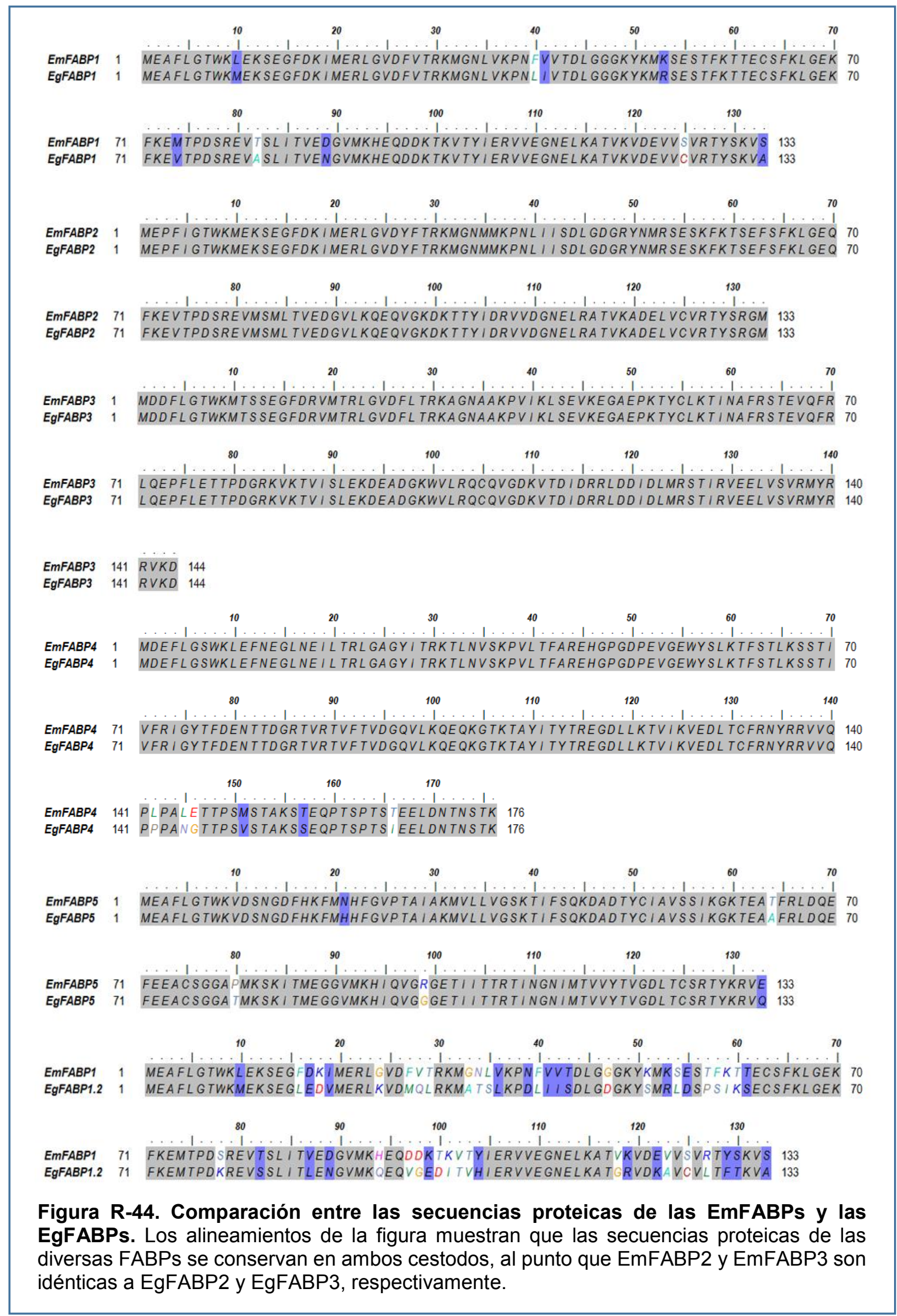


correspondientes a la familia de las FABPs, faltando la tercera, que abarca la región entre los aminoácidos 111 y 131 (Ver Figura R-47).

El haber podido clonar las CDS de los genes correspondientes a EmFABP3 y EmFABP4, y que la comparación de dichas CDS con el ADN genómico permita detectar la presencia, en ambos casos, de un intrón que las interrumpe, nos lleva a pensar que las FABPs carentes de intrones predichas por Y. Zheng et al. (2013) serían un artefacto. Cabe destacar también que las secuencias que hemos predicho para EgFABP5 y EmFABP5 (esta última incluso clonada) no han sido reportadas en dicho estudio.

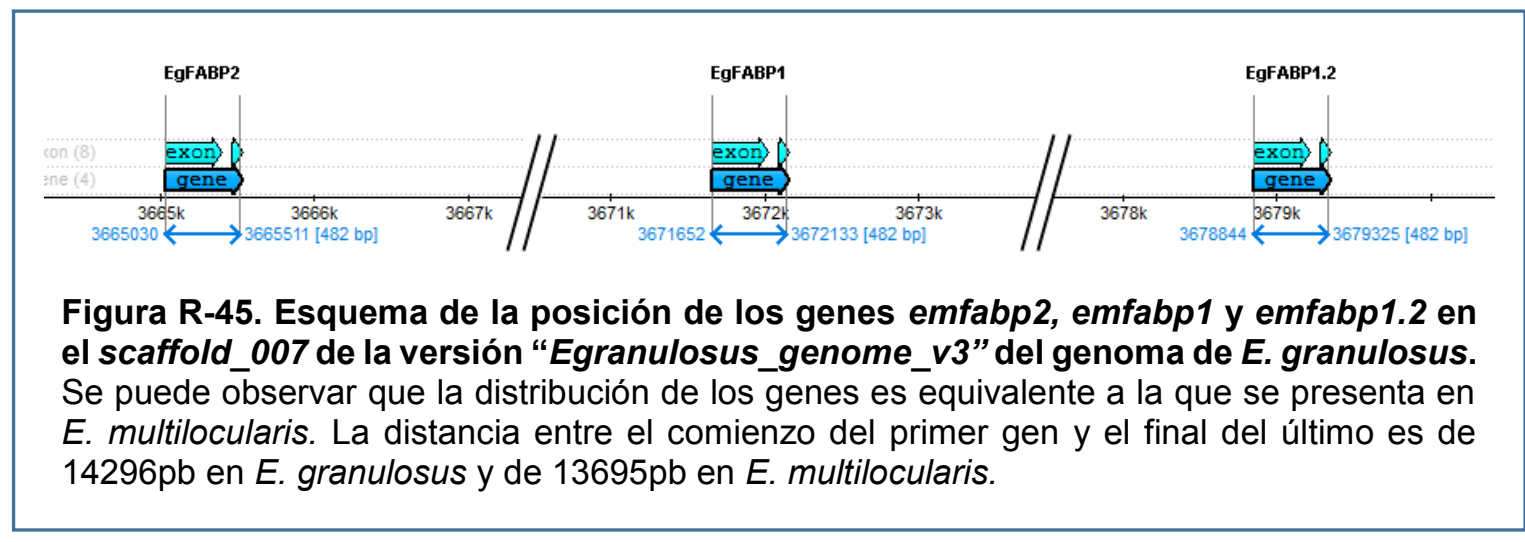

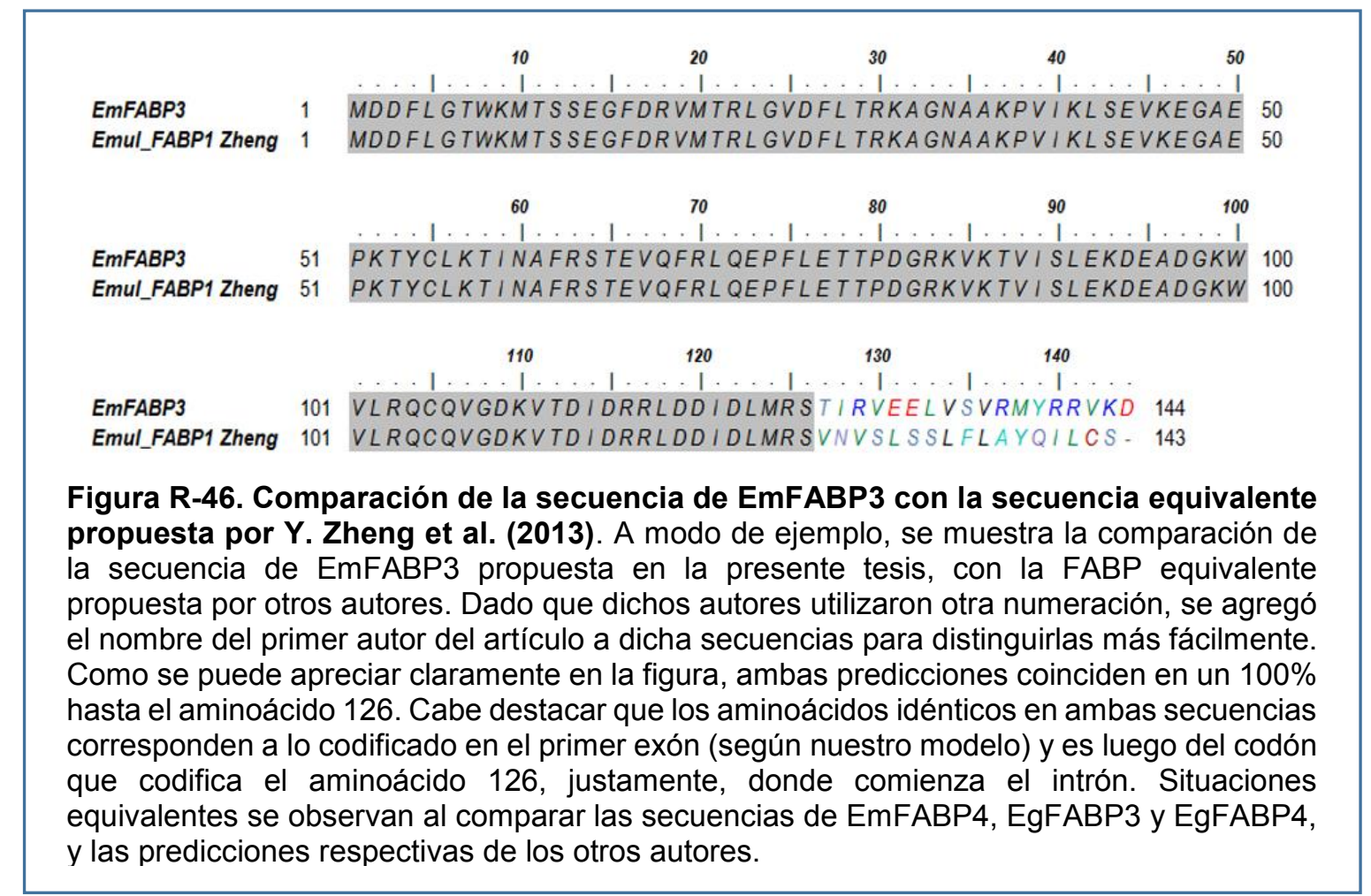


Figura R-47. Análisis de los dominios de la proteína Emul_FABP1 predicha por Y. Zheng et al. (2013). Como se mencionó en la Figura R-46, la nomenclatura utilizada por los autores de dicho trabajo es diferente a la utilizada en la presente tesis, pero la proteína en cuestión equivaldría a nuestra EmFABP3. El análisis de los dominios realizado con la herramienta InterPro muestra la ausencia de la última fingerprint correspondiente al patrón PRINTS FATTYACIDBP (PR00178). Dicho motivo sí se encuentra en la secuencia propuesta para nuestra EmFABP3.

\subsubsection{Análisis de la expresión a nivel transcripcional de FABPs en $E$. multilocularis}

Con la intención de obtener algún tipo de información sobre los patrones de expresión de las FABPs de E. multilocularis se realizó un ensayo preliminar mediante RT-PCR semicuantitativa. Para ello, se utilizó cDNA de capa germinativa, protoescólices y protoescólices activados por tratamiento con ácido y pepsina (todos pertenecientes al aislamiento GH09) gentilmente cedidos por el Dr. Uriel Koziol (Universidad de Wurzburgo, Alemania). Cabe recordar que al momento de realizar estos experimentos, no se contaba con los primers para la CDS de EmFABP3, por lo que no fue tenido en cuenta en el mismo.

Como se puede observar en la Figura R-48, EmFABP1 y EmFABP5 parecen expresarse tanto en la capa germinativa como en protoescólices de $E$. mutilocularis, ya sea que éstos estén activados o no. EmFABP2, por su parte, pareciera expresarse mayormente en la capa germinativa de dicho cestodo, mientras que EmFABP4 pareciera ser exclusiva de los protoescólices. Cabe destacar que la expresión que aquí se analiza es en términos de transcripción de los genes correspondientes, lo cual no asegura que las proteínas respectivas sean traducidas. Por otra parte, como se discutió en la Introducción de este trabajo, tanto la capa germinativa como los protoescólices contienen una gran diversidad de tipos celulares, por lo que las diferentes EmFABPs podrían estar expresándose en distintos tejidos o tipos celulares de $E$. multilocularis, de modo análogo a lo que ocurre en otros organismos.

No obstante lo comentado, claramente queda mucho trabajo por hacer en lo referido al análisis de la expresión de las diferentes FABPs en ambos cestodos, en diferentes estadios y tejidos de los mismos. Un análisis de ese tipo podría ayudar a comprender mejor las posibles funciones de estas proteínas, del mismo modo que ha ocurrido en otros organismos. 

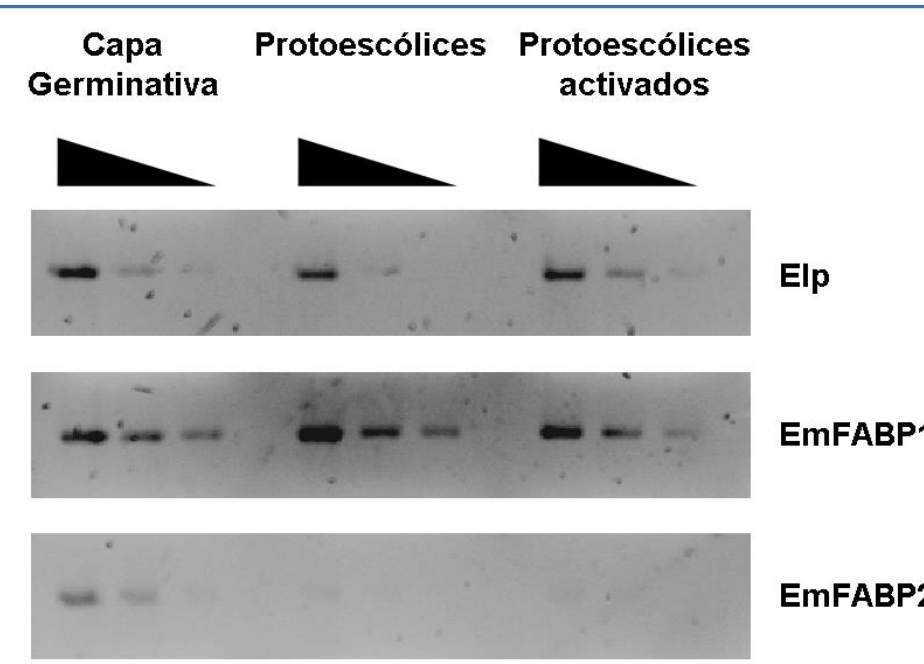

EmFABP2

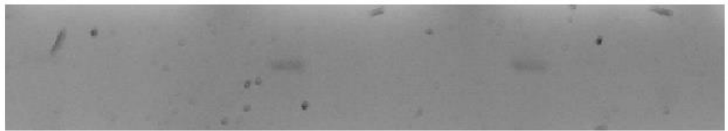

\section{EmFABP4}

\section{EmFABP5}

Figura R-48. Análisis de la expresión relativa de diferentes EmFABPs en diferentes tejidos de E. multilocularis. La figura muestra los resultados de RT-PCR semicuantitativas realizadas sobre cDNA de capa germinativa, protoescólices y protoescólices activados de $E$. multilocularis. La activación de los protoescólices con pepsina y ácido simula la entrada del cestodo al intestino de su hospedador definitivo, en donde se desarrolla hacia el estadio adulto. Los triángulos negros simbolizan las diluciones seriadas del cDNA molde utilizado. EI gen que codifica para la proteína Elp se utilizó también en este caso para comparar con los de las FABPs. 


\section{DISCUSIÓN GENERAL}




\section{DISCUSIÓN GENERAL}

Al introducir el presente trabajo de tesis se planteó como hipótesis general que las FABPs de Echinococcus spp. podrían intervenir en el direccionamiento de ácidos grasos hacia las vías de síntesis de fosfolípidos de membrana, necesarios para sostener el crecimiento continuo del metacestodo en los hospedadores intermediarios, así como también de moléculas de señalización que permitan evadir la respuesta inmune de los hospedadores. Asimismo, las FABPs podrían intervenir en la regulación de la plasticidad fenotípica que caracteriza a estos cestodos, por ejemplo, transportando ligandos al núcleo para interactuar con factores de transcripción.

Dentro de esta hipótesis compleja, particularmente nos planteamos analizar la interacción de EgFABP1 con ligandos y membranas fosfolipídicas artificiales, así como ampliar nuestro conocimiento en relación a otras FABPs del género Echinococcus, más recientemente descriptas.

El análisis de la interacción de EgFABP1 con ligandos fue abordado desde distintos puntos de vista, empleando distintas aproximaciones experimentales. Por un lado, se analizaron los ligandos hidrofóbicos que co-purifican unidos a EgFABP1 cuando la proteína es expresada de manera recombinante en células de $E$. coli. Si bien, como se comentó anteriormente, $E$. coli no es el ambiente natural en el que EgFABP1 se encuentra, nos propusimos analizar qué tipos de ligandos se unían a ella en un entorno complejo, como un citoplasma celular. Es importante remarcar que, aun cuando el contenido del citoplasma de una bacteria pueda diferir del de una célula eucariota como la de Echinococcus spp., el mismo es un sistema claramente más complejo que una mezcla generada in vitro como puede ser el caso de un ensayo de titulación. A través de dicho ensayo, pudimos observar que EgFABP1 sería capaz de unir únicamente ácidos grasos, al menos dentro del espectro de ligandos disponibles en $E$. coli. Asimismo, dentro de los ácidos grasos unidos a EgFABP1, se pudieron detectar varios ácidos grasos diferentes, tanto saturados como insaturados, coincidiendo en gran medida con lo observado previamente en ensayos de competición in vitro (Alvite et al., 2001). Por otra parte, también se realizaron ensayos con el fin de evaluar la posibilidad de que la unión de ligandos indujera cambios conformacionales en EgFABP1. Para ello, se realizaron ensayos de digestión parcial de EgFABP1 en su forma apo o unida a diferentes ácidos grasos, y se analizaron los espectros de dicroísmo circular de la proteína en presencia o ausencia de ligandos. Tal como se discutió previamente, si bien a partir de estos experimentos no es posible concluir qué cambios conformacionales sufre EgFABP1 al unirse a los diversos ligandos ensayados, sí fue posible determinar que los efectos producidos por el ácido oleico fueron diferentes a los causados por los otros ácidos grasos. En este sentido, sería interesante analizar la capacidad de EgFABP1 de "activarse" diferencialmente por unión a ciertos 
ligandos, efecto que se ha observado para otras proteínas de la familia de las FABPs, como A-FABP, E-FABP y la proteína relacionada, CRABP-II (Armstrong et al., 2014; Gillilan et al., 2007; Sessler \& Noy, 2005). Dicha activación se basa en que, estabilizadas por diferentes ligandos, estas proteínas adoptan conformaciones tridimensionales en las que se expone una señal de localización nuclear que permite su translocación al núcleo. Cabe destacar que algunos ligandos que favorecen dicha translocación, activan también a ciertos receptores nucleares de la familia de los PPAR que interactúan específicamente con cada FABP, modulando de este modo la transcripción de genes relacionados, entre otros aspectos, con el metabolismo lipídico, la homeostasis energética y la diferenciación celular (Tan et al., 2002). Estos resultados sugieren que no sería la capacidad de una determinada FABP de unir un ligando lo que determinaría su función, sino el efecto que dicho ligando tenga sobre la proteína. Cabe destacar que estudios in silico llevados a cabo por la Dra. Esteves y colaboradores, han señalado al ácido oleico como uno de los ligandos que induciría mayores cambios en la conformación de EgFABP1, comparado con la proteína en su forma apoEgFABP1 (Esteves \& Paulino, 2013). Asimismo, en dicho estudio se destaca que el ácido oleico, pero no el ácido palmítico, sería capaz de modificar la posición de la $\mathrm{Phe}^{58}$, la cual podría intervenir en la exposición de la señal de localización nuclear, que en EgFABP1 estaría compuesta por $\mathrm{Arg}^{22}, \mathrm{Arg}^{30}$ y $\mathrm{Lys}^{31}$, de modo análogo a lo que ocurre con A-FABP (Gillilan et al., 2007). Por otra parte, el análisis de las mismas interacciones en un modelo de EgFABP2 no parecen brindar evidencia de tal modificación, al menos con los ligandos ensayados (Esteves \& Paulino, 2013). Estas observaciones abren un nuevo panorama, sumamente interesante, en el estudio de las FABPs de Echinococcus spp., así como también en el estudio de los posibles roles regulatorios que podrían tener diferentes ligandos hidrofóbicos, mediados por la acción de las FABPs, en el desarrollo y diferenciación de las células de estos cestodos.

Por otra parte, a partir de los ensayos de transferencia de ligandos fluorescentes a membranas fosfolipídicas, se pudo establecer que EgFABP1 transfiere los ácidos grasos a través de un mecanismo de tipo colisional. Como se discutió al presentar dichos resultados, el mecanismo de transferencia de tipo colisional es un modelo que plantea que la FABP debe tener contacto directo con la membrana fosfolipídica para ceder el ligando que transporta. Si bien se trata de un modelo sumamente simplificado, ya que las membranas biológicas son mucho más complejas que una bicapa fosfolipídica de composición uniforme, estos experimentos han sido muy utilizados en la caracterización de las FABPs y proteínas relacionadas. De hecho, ha sido en gran parte gracias a estos experimentos que se pudo establecer la importancia de la región portal de las FABPs, siendo ésta la zona que determina en gran medida las características funcionales de cada una de las diferentes proteínas de la familia. Estudios posteriores han determinado que, efectivamente, es en dicha región donde se encuentran sitios de interacción con otras proteínas, donde se producen cambios 
conformacionales importantes para la funcionalidad de las FABPs, etc. (Storch \& Córsico, 2008; Storch \& McDermott, 2009; Storch \& Thumser, 2010). Asimismo, la capacidad de EgFABP1 de interactuar con membranas deja abierta la posibilidad de que a través de dicha interacción pueda retirar ácidos grasos de ciertas membranas (o subdominios de membrana) celulares para dirigirlos hacia otras localizaciones o vías metabólicas. Debe remarcarse, no obstante, que dicha interacción podría no darse directamente entre EgFABP1 y los fosfolípidos de las membranas, sino que podría estar mediada por la interacción con alguna otra proteína, sobre todo si se tienen en cuenta los modelos más actuales de las membranas celulares que proponen que las mismas poseen una estructura altamente poblada de proteínas que interactúan con determinados dominios lipídicos, con proteínas del citoesqueleto y/o componentes de la matriz extracelular (Nicolson, 2014).

Otro aspecto que fue abordado en el estudio de las FABPs de Echinococcus spp. en el presente trabajo, radicó en la búsqueda de los genes ortólogos a egfabp1 y egfabp2 de $E$. granulosus en el genoma de E. multilocularis, así como en la identificación de nuevos genes de la familia en ambos cestodos. Estos análisis fueron posibles gracias a la reciente publicación de los genomas de E. granulosus y E. multilocularis (Tsai et al., 2013; H. Zheng et al., 2013). Los resultados obtenidos han arrojado datos muy interesantes en lo que respecta a la familia de las FABPs del género Echinococcus. Por un lado, se encontró que $E$. multilocularis no sólo posee genes ortólogos a los que codifican para las proteínas EgFABP1 y EgFABP2 de E. granulosus, sino que ambos cestodos poseen varios genes más pertenecientes a esta familia de proteínas. La alta similitud entre ortólogos de ambas especies y la conservación de la ubicación relativa de los genes en los genomas de ambos cestodos conduce a pensar que la familia de FABPs del género Echinococcus se habría generado antes de la especiación de E. granulosus y E. multilocularis. Una observación muy llamativa derivada de los análisis de los datos genómicos es el hecho de que en E. multilocularis existan dos copias iguales de un mismo gen (emfabp1), mientras que en E. granulosus una de dichas copias se haya diferenciado de la otra (egfabp1 y egfabp1.2). Existen diferentes modelos que intentan explicar cómo surgen nuevos genes con nuevas funciones a lo largo de la evolución (Conant \& Wolfe, 2008). Gran parte de ellos toman como base para la aparición de nuevos genes la duplicación de genes preexistentes. De ese modo, una vez presentes dos copias del gen en cuestión, las mismas pueden sufrir mutaciones que permitan el surgimiento de nuevas funciones (neofuncionalización), o que favorezcan ciertas funciones, preexistentes en el gen original, en cada una de las copias (subfuncionalización) dando como resultado dos genes, cada uno con una función optimizada del gen original. Por otro lado, pueden también conservarse ambas copias, de modo de aumentar el dosaje del gen en cuestión, si es que ello brinda alguna ventaja adaptativa (Conant \& Wolfe, 2008). Teniendo esto en cuenta, y si efectivamente las FABPs del género Echinococcus estuvieran involucradas en el 
direccionamiento de ácidos grasos a vías de síntesis de fosfolípidos y otros compuestos para sostener el crecimiento continuo del metacestodo, se podría especular que el aumento en el dosaje de EmFABP1 en E. multilocularis podría estar relacionado con el crecimiento mucho más rápido del metacestodo de dicho parásito, comparado con el de E. granulosus. Por otra parte, las variaciones observadas en una de las copias del gen ortólogo a emfabp1 en $E$. granulosus, podría significar la adquisición de nuevas funciones por parte de dicho gen. Existe también la posibilidad de que el gen que hemos denominado egfabp1.2 pudiera ser un pseudogen, aunque hay alguna evidencia obtenida de datos transcriptómicos que indicarían que dicho gen se transcribe en protoescólices de E. granulosus (Tsai et al., 2013; H. Zheng et al., 2013).

Por otra parte, como se indicó en la Tabla $R-4$, al comparar la secuencia de EmFABP3 con las bases de datos de proteínas del NCBI mediante BLASTP se encontró que la secuencia a la que más se asemeja (excluyendo las del género Echinococcus) es la de una proteína que une ácidos grasos y retinol de $T$. solium. Si bien se ha determinado experimentalmente que dicha proteína de $T$. solium es capaz de unir retinol (Kim et al., 2012), la denominación de la misma como fatty acid and retinol binding protein puede conducir a confusiones, ya que dicha denominación se ha asignado a una familia de proteínas exclusivas de nematodos, ricas en a-hélices y no relacionadas con las FABPs (Garofalo et al., 2002; Prior et al., 2001). Por otra parte, se cree que la subfamilia de las CRBPs/CRABPs ha surgido en la evolución luego de la separación entre vertebrados e invertebrados, por lo que tampoco corresponderían, a priori, a dicho grupo (Esteves \& Ehrlich, 2006; Folli et al., 2005; Schaap et al., 2002). Asimismo, se ha reportado que FABPs tales como A-FABP, mP2 y E-FABP, a las cuales se asemejan principalmente las FABPs de Echinococcus spp. aquí descriptas, son capaces de unir retinoides (Schaap et al., 2002). De acuerdo a lo expuesto, sería recomendable seguir considerando a EmFABP3 y EgFABP3 como miembros de la familia de las FABPs; salvo que futuras caracterizaciones sugieran que pertenecen a otra familia (o subfamilia) de proteínas de unión a lípidos.

La evidencia recolectada, que indica la existencia de varios miembros de la familia de las FABPs en Echinococcus spp., pone de relieve la importancia que estas proteínas podrían tener en estos cestodos y modifica parcialmente la visión que se tenía acerca de estas proteínas en invertebrados. El hecho de que gran parte de las FABPs descubiertas en invertebrados se asemejaran mayormente a las FABPs de vertebrados de un mismo grupo (el que incluye a H-FABP, A-FABP, mP2, etc.) y que existiera sólo una o dos proteínas de la familia por especie, habían sugerido que tal vez una única $F A B P$, menos específica en su unión a ligandos y más promiscua en cuanto a las interacciones con otras proteínas, podría ser capaz de llevar a cabo todas las funciones que en vertebrados se han asignado a las diferentes FABPs (Esteves \& Ehrlich, 2006). El panorama actual, que indicaría que habría al 
menos cinco FABPs diferentes en E. multilocularis y seis en $E$. granulosus, hace pensar que cada una de ellas tendría diferentes roles y/o se podría expresar en diferentes tipos celulares o estadios de estos organismos. Asimismo, como se ha mencionado previamente, algunas de ellas poseen ciertas variaciones en algunos de los aminoácidos que constituyen el motivo P2 de unión a ligandos, lo que indicaría que las mismas podrían ser capaces de unir otro tipo de compuestos hidrofóbicos y no necesariamente (o únicamente) ácidos grasos; o bien, que unirían a sus ligandos de otra manera. Los datos de RNA-seq obtenidos por Tsai et al. (2013) indican que todas las FABPs aquí descriptas, a excepción de EmFABP5 y EgFABP5 que no fueron anotadas en dicho genoma, se expresarían (en menor o mayor medida) en metacestodos y adultos de E. multilocularis y en protoescólices de E. granulosus.

Por otra parte, los datos transcriptómicos de E. granulosus publicados junto al genoma de dicho organismo por $\mathrm{H}$. Zheng et al. (2013) brindan mayor información en relación a la expresión de las FABPs de E. granulosus en distintos estadios. En ese caso, se han predicho las seis variantes de FABPs presentadas en este trabajo, aunque la proteína homóloga a EgFABP1 se presenta truncada (a pesar de haber sido la primera en ser descubierta y la mejor caracterizada) y la correspondiente a la EgFABP5 presenta una variación, aparentemente debida a la predicción diferente del sitio de splicing. Si bien EgFABP5 aún debe ser clonada, es muy posible que sus sitios de splicing se correspondan a los determinados a partir del clonado de la CDS para EmFABP5, dada la alta similitud que presentan estas secuencias entre E. granulosus y E. multilocularis. Sin embargo, no obstante las diferencias planteadas, se puede observar a partir de los datos transcriptómicos que todas las EgFABPs se expresan en al menos un estadio de E. granulosus. En particular, EgFABP5 se expresaría solo en adultos y oncosfera, mientras que EgFABP2 y EgFABP4 se expresarían en todos los estadios salvo en la oncosfera. Por otra parte, se observa que en adulto aumentaría significativamente la expresión de EgFABP1.2, EgFABP2 y EgFABP4 con respecto a los otros estadios, mientras que EgFABP1 disminuiría su expresión en la oncosfera con respecto a los demás estadios. Dichas diferencias de expresión, no obstante, se analizaron a nivel de mRNA, por lo que se debe tener en cuenta que a nivel proteico podría haber variaciones, si es que hubiera mecanismos post-transcripcionales de regulación de la expresión. A nivel proteico, existe evidencia obtenida a partir de análisis proteómicos de que EgFABP3, aparte de EgFABP1, se expresaría en protoescólices de E. granulosus (Lic. Maite Folle, UdelaR, Montevideo; comunicación personal). 
Cabe destacar que un análisis más profundo de la expresión de las FABPs podría determinar a qué se debe el aumento de la expresión de alguna de ellas en determinados estadios. Este aumento podría deberse a una inducción de la transcripción en células o tejidos preexistentes y/o a la diferenciación celular hacia nuevos tejidos. Asimismo, dicha información podría contribuir a la comprensión de las funciones de estas proteínas. 


\section{CONCLUSIONES}




\section{CONCLUSIONES}

A continuación se resumen los datos obtenidos a partir del presente trabajo:

- Se subclonó la secuencia codificante de la proteína EgFABP1 a un plásmido con un mayor control de la expresión

- Se mejoró el protocolo de deslipidización de EgFABP1

- Se confirmó que EgFABP1 es capaz de unir ácidos grasos de diversa longitud de cadena y grado de insaturación

- Se observó que la unión de ligandos induce diferentes cambios conformacionales en EgFABP1 dependiendo del ácido graso unido

- Se caracterizó el mecanismo de transferencia de análogos de ácidos grasos hacia membranas fosfolipídicas artificiales, determinándose un mecanismo de tipo colisional

- Se analizó la presencia de varios genes de la familia de las FABPs tanto en E. granulosus como en E. multilocularis

- Se clonaron las secuencias codificantes de las cinco FABPs encontradas en E. multilocularis

- Se intentó silenciar la expresión de EmFABP1 y EmFABP2 en cultivos de células primarias de E. multilocularis empleando la tecnología de interferencia de ARN por siRNAs

- Se realizaron estudios preliminares de expresión a nivel transcripcional de las FABPs de E. multilocularis en distintos estadios parasitarios

En conjunto, los resultados aquí presentados amplían el conocimiento en relación no sólo a las características funcionales de EgFABP1 sino al panorama actual en relación a la familia de las FABPs en organismos invertebrados, y en particular, en cestodos del género Echinococcus, habiéndose encontrado interesantes diferencias entre las dos principales especies de dicho género. 


\section{PERSPECTIVAS FUTURAS}




\section{PERSPECTIVAS FUTURAS}

Como se desprende de lo presentado en esta tesis, la investigación en el campo de las FABPs es un área en la que resta mucho por descubrir. Más aún cuando se trata de organismos tales como Echinococcus spp. cuyo metabolismo se conoce tan poco, y cuyo impacto en la salud pública y la ganadería son tan importantes. A continuación se plantean algunos aspectos que sería interesante abarcar en futuras investigaciones tendientes a ampliar el conocimiento del rol de las FABPs en la biología y metabolismo de Echinococcus spp.:

- Subclonar y expresar las FABPs recombinantes de E. multilocularis y E. granulosus

- Caracterizar sus propiedades de interacción con ligandos y membranas, con la finalidad de poder clasificarlas en subgrupos de modo análogo a lo realizado para las FABPs de mamíferos

- Generar herramientas tales como anticuerpos y sondas específicas para cada proteína o mRNA de forma de poder profundizar en el conocimiento de los patrones de expresión de las diferentes FABPs tanto en diferentes estadios como tipos celulares, en E. granulosus y E. multilocularis

- Evaluar el comportamiento de las distintas FABPs en respuesta a diferentes ligandos, ya sea desde el punto de vista conformacional, como de localización intracelular

- Evaluar la capacidad de unión a inhibidores de FABPs por parte de estas proteínas y determinar el efecto que ello pudiera tener en la sobrevida y desarrollo de los parásitos; basándose en datos previos obtenidos para otras FABPs de estructura similar, como AFABP (Cai et al., 2015; Chen et al., 2014; Hertzel et al., 2009; Wang et al., 2015, 2014)

- Profundizar en los ensayos de silenciamiento de las FABPs como una estrategia adicional para esclarecer el rol que cumplen estas proteínas en Echinococcus spp. 


\section{APÉNDICES}




\section{APÉNDICES}

\subsection{Listado de primers y siRNAs}

\subsubsection{Primers}

Los parámetros tabulados ( $\mathrm{N}$, número de bases; \%GC; y $\mathrm{T}_{\mathrm{M}}$, temperatura de melting, o fusión) fueron calculados empleando la herramienta OligoCalc, disponible en http://www.basic.northwestern.edu/biotools/oligocalc.html.

\begin{tabular}{|c|c|c|c|c|}
\hline Nombre & Secuencia $\left(5^{\prime} \rightarrow 3^{\prime}\right)$ & $\mathbf{N}$ & $\%$ GC & $\begin{array}{l}\mathrm{T}_{\mathrm{M}} \\
\left({ }^{\circ} \mathrm{C}\right)\end{array}$ \\
\hline EgFABP1-Fw ${ }^{(a)}$ & GAGCATATGGAGGCATTCCTTGGTACCT & 28 & 50 & 61,4 \\
\hline EgFABP1-Rv ${ }^{(b)}$ & GTTGGATCCGAATTCTTACGCCACCTTTG & 29 & 48 & 61,5 \\
\hline EmFABP1-CDS-Fw & ATGGAGGCGTTCCTCGGTA & 19 & 58 & 53,2 \\
\hline EmFABP1-CDS-Rv & TTACGACACCTTTGAGTAGGTTC & 23 & 43 & 53,5 \\
\hline EmFABP2-CDS-Fw & ATGGAGCCATTCATCGGTA & 19 & 47 & 48,9 \\
\hline EmFABP2-CDS-Rv & TTACATCCCTCTTGAGTAGGTTCG & 24 & 46 & 55,7 \\
\hline EmFABP3-CDS-Fw & ATGGATGACTTTCTGGGCACCT & 22 & 50 & 54,8 \\
\hline EmFABP3-CDS-Rv & TCAGTCCTTTACTCGACGATACA & 23 & 43 & 53,5 \\
\hline EmFABP4-CDS-Fw & ATGGATGAATTTCTGGGATCCTG & 23 & 43 & 53,5 \\
\hline EmFABP4-CDS-Rv & TTATTTTGTCGAATTAGTATTATCCAA & 27 & 22 & 49,1 \\
\hline EmFABP5-CDS-Fw & ATGGAGGCATTCCTAGGCAC & 20 & 55 & 53,8 \\
\hline EmFABP5-CDS-Rv & СTACTCCACTCGTTTGTAAGTT & 22 & 41 & 51,1 \\
\hline Elp-Fw & AATAAGGTCAGGGTGACTAC & 20 & 45 & 49,7 \\
\hline Elp-Rv & TTGCTGGTAATCAGTCGATC & 20 & 45 & 49,7 \\
\hline
\end{tabular}

(a) La secuencia resaltada en el primer EgFABP1-Fw corresponde al sitio de corte de la enzima Ndel.

(b) El sitio resaltado en el primer EgFABP1-Rv es el de BamHI, y el subrayado, el de EcoRI. 


\subsubsection{SiRNAs}

Los parámetros tabulados ( $\mathrm{N}, \% \mathrm{GC}$ y $\mathrm{T}_{\mathrm{M}}$ ) corresponden a los datos provistos por el fabricante de los siRNAs (Sigma Aldrich).

\begin{tabular}{|c|c|c|c|c|}
\hline Nombre & Secuencia (a) & N & \%GC & Tм \\
\hline siRNA-gfp & 5'-ACAUGAAGCAGCACGACUUCUUC-3' & 23 & 47,8 & 62,3 \\
\hline siRNA-emfabp1 & 5'-AUUUGGUUAAACCCAACUUCGUA-3' & 23 & 34,7 & 57,1 \\
\hline siRNA-emfabp2 & 5'-CGAUCUGGGUGAUGGCAGGUAUA-3' & 23 & 52,1 & 65,6 \\
\hline
\end{tabular}

(a) Sólo se transcribe la secuencia de la hebra correspondiente a la hebra codificante de cada gen. 


\subsection{Plásmidos empleados}

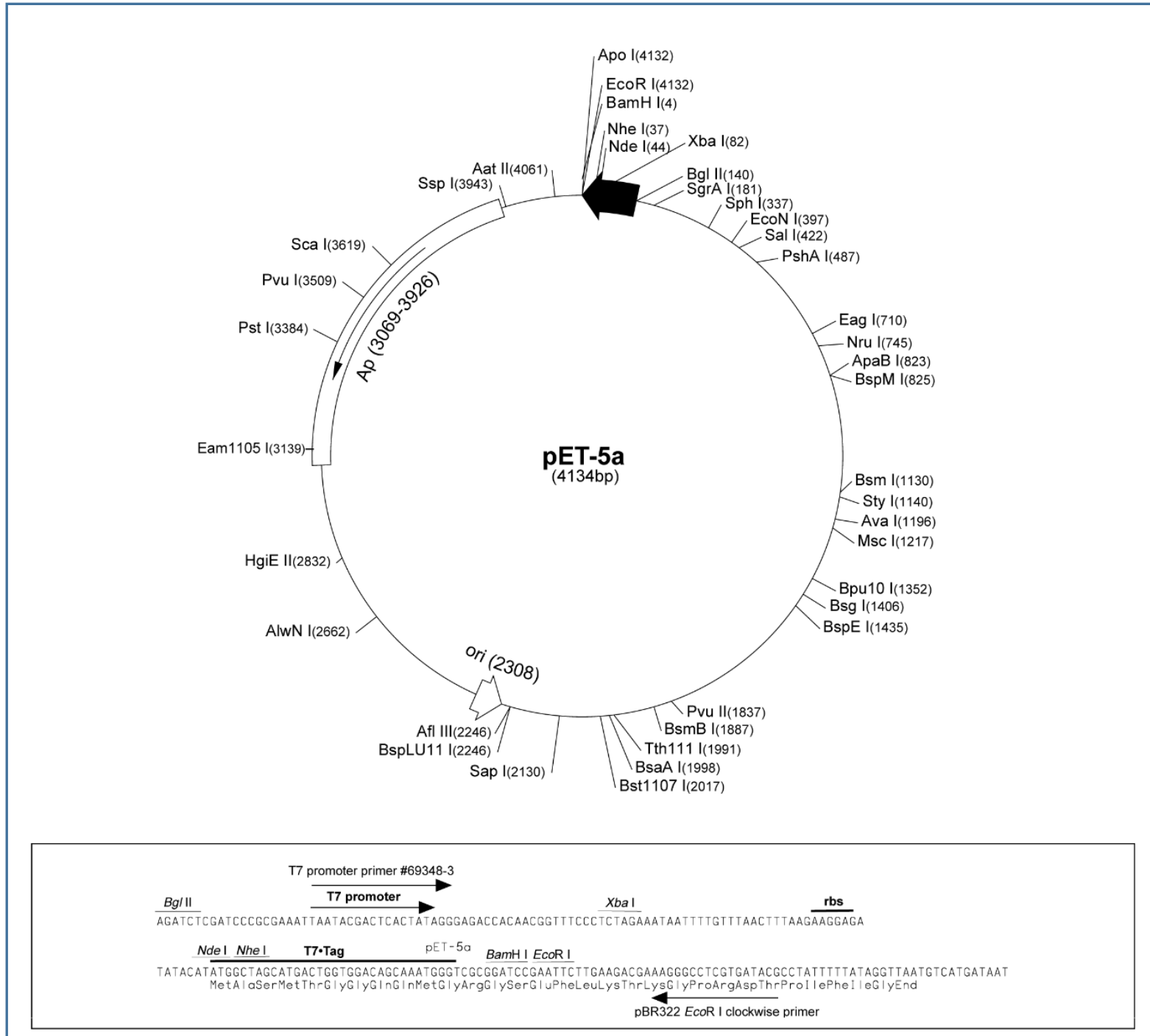

Figura A-1. Mapa del vector $\mathrm{pET}-5 a$. En la figura se muestra el mapa del vector $p E T-5 a$, en el que se hallaba clonada la CDS para la proteína EgFABP1. Dicha CDS había sido clonada con las enzimas de restricción Ndel y EcoRl. Como se puede ver en la figura, este plásmido carece de terminador de la transcripción, por lo que el gen de resistencia aumenta su transcripción también al inducirse la expresión del inserto clonado. 

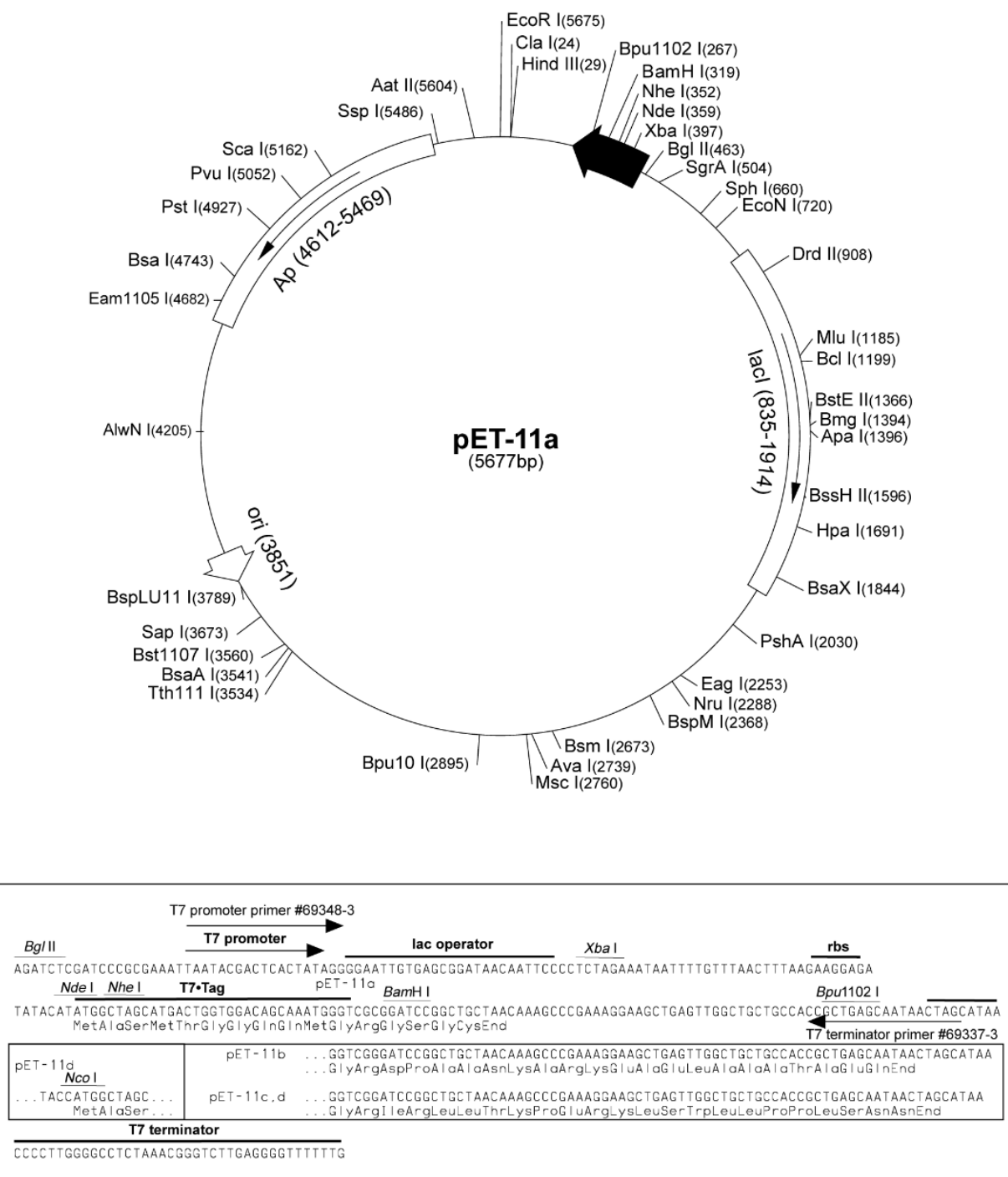

Figura A-2. Mapa del vector pET-11a. En la figura se muestra el mapa del vector $p E T-11 a$. La CDS para la proteína EgFABP1 se subclonó en el plásmido $p E T-11 b$ que sólo difiere del $p E T$ 11a por la eliminación de una base previa al sitio $B a m H I$, lo cual genera un cambio en el marco de lectura de lo que se halle clonado allí. No obstante, a los fines del subclonado realizado en la presente tesis, ambos plásmidos son equivalentes, ya que se clonó entre los sitios $\mathrm{Ndel}$ y $\mathrm{BamHI}$. Como se puede ver en la figura, este plásmido posee terminador de la transcripción, por lo que la expresión del gen de resistencia está más regulada y no se induce junto la expresión de la proteína de interés. Asimismo, este plásmido posee el operador lac, que permite también mantener reprimida la expresión de la proteína recombinante hasta que se induzca la misma con IPTG. 

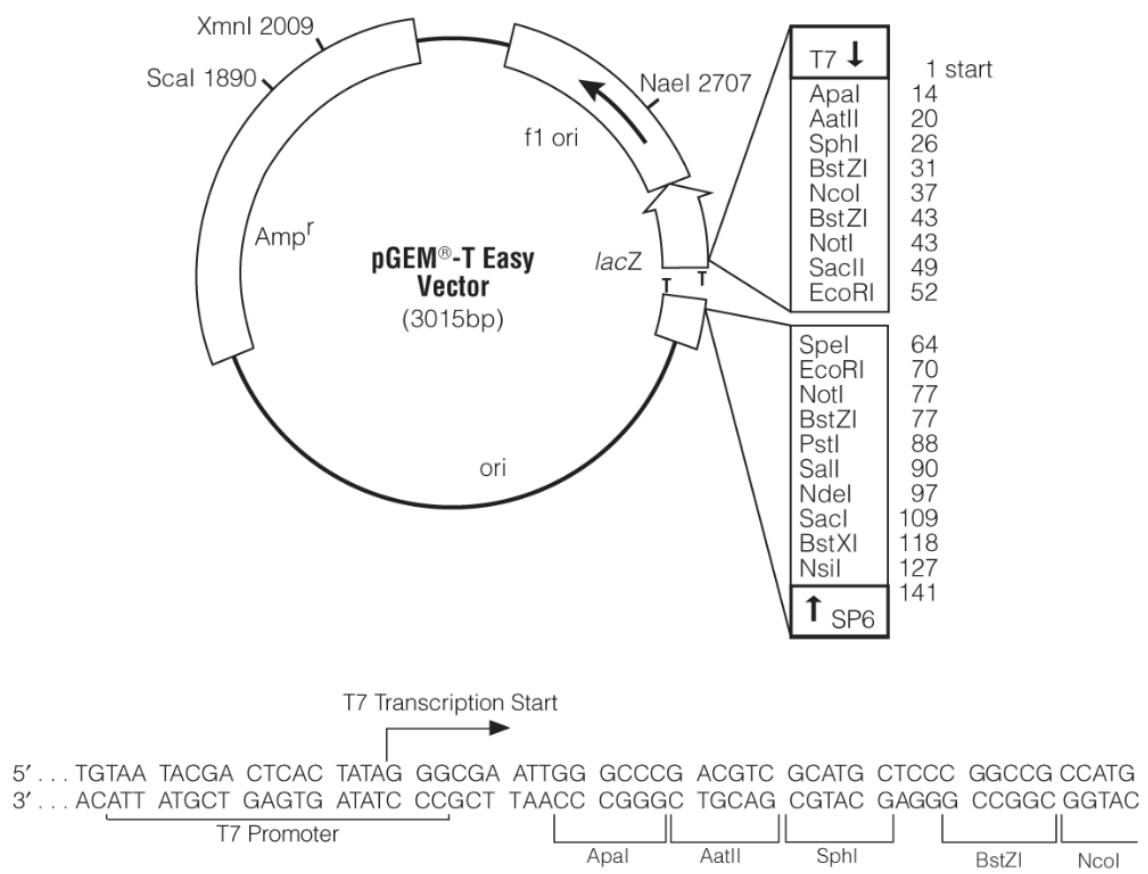

GCGGC CGCGG GAATT CGATT3'( ${ }^{\prime}$ ATCAC TAGTG AATTC GCGGC CGCCT GCAGG TCGAC

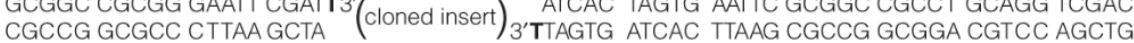

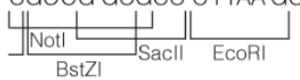

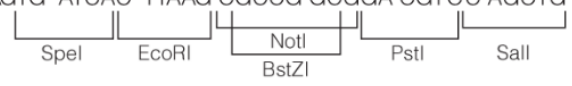

SP6 Transcription Start

CATAT GGGA GAGCT CCCAA CGCGT TGGAT GCATA GCTTG AGTAT TCTAT AGTGT CACCT AAAT . . .

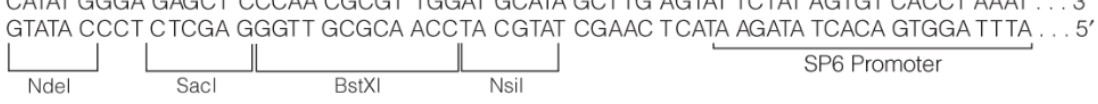

Figura A-3. Mapa del vector pGEM-T Easy. En la figura se muestra el mapa del vector pGEM-T Easy utilizado para el clonado de las CDS de las FABPs predichas en $E$. multilocularis. Se pueden observar los nucleótidos de timina desapareados que sirven para aparearse con las adeninas protruyentes de los insertos y así facilitar el proceso de ligación. En la región indicada como SP6 promoter se aparea el primer universal empleado para la secuenciación de los plásmidos recombinantes obtenidos luego del clonado de las CDS de las distintas EmFABPs. 


\subsection{Verificación de secuencias clonadas}

\subsubsection{Inserto de EgFABP1 subclonado en pET-11b}

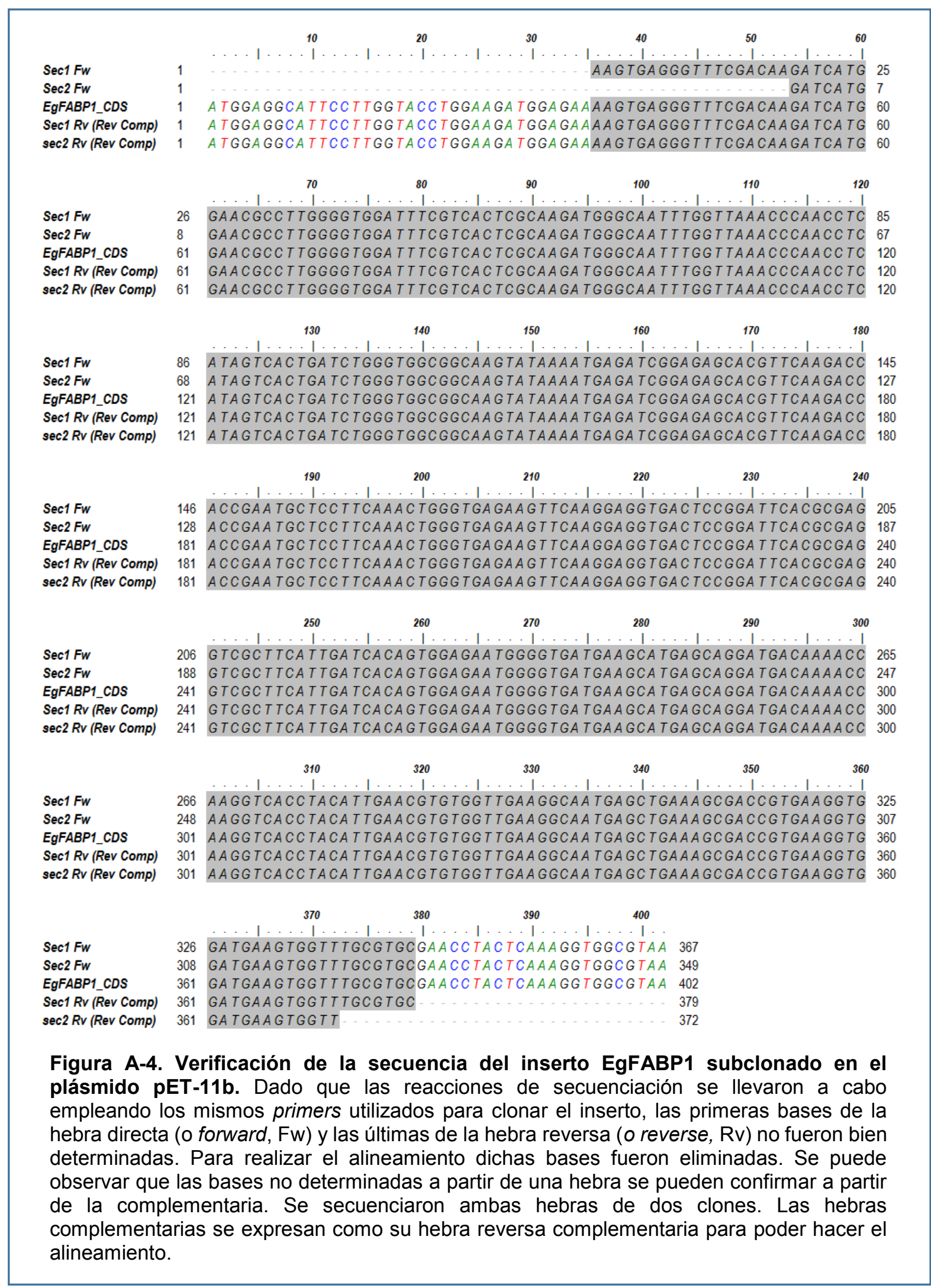




\subsubsection{EmFABPs clonadas en PGEM-T}
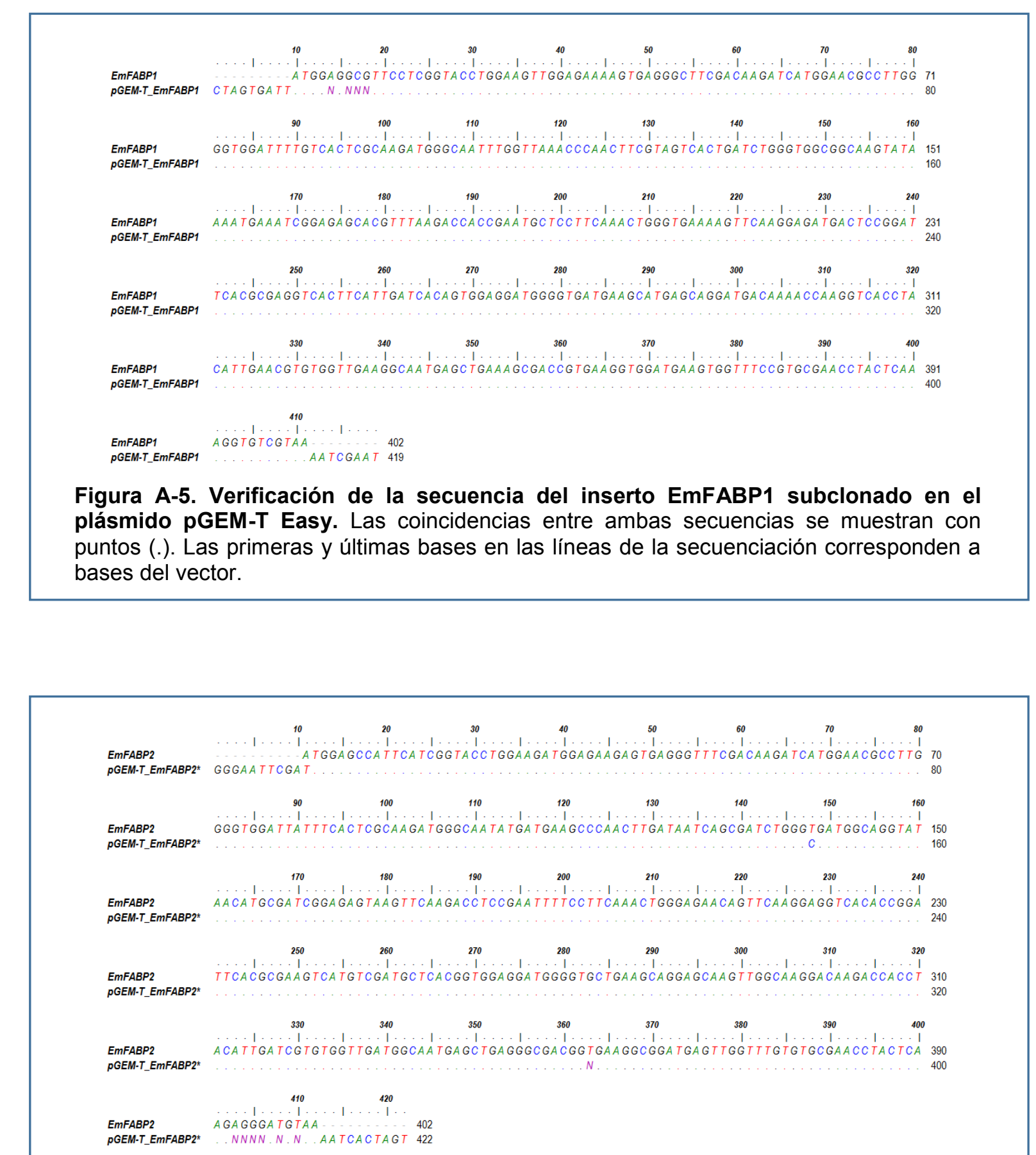

Figura A-6. Verificación de la secuencia del inserto EmFABP2 subclonado en el plásmido pGEM-T Easy. Las coincidencias entre ambas secuencias se muestran con puntos (.). Las primeras y últimas bases en las líneas de la secuenciación corresponden a bases del vector. El error en la primera base del inserto podría deberse a un artefacto de clonado. Deben secuenciarse otros clones para confirmarlo. 


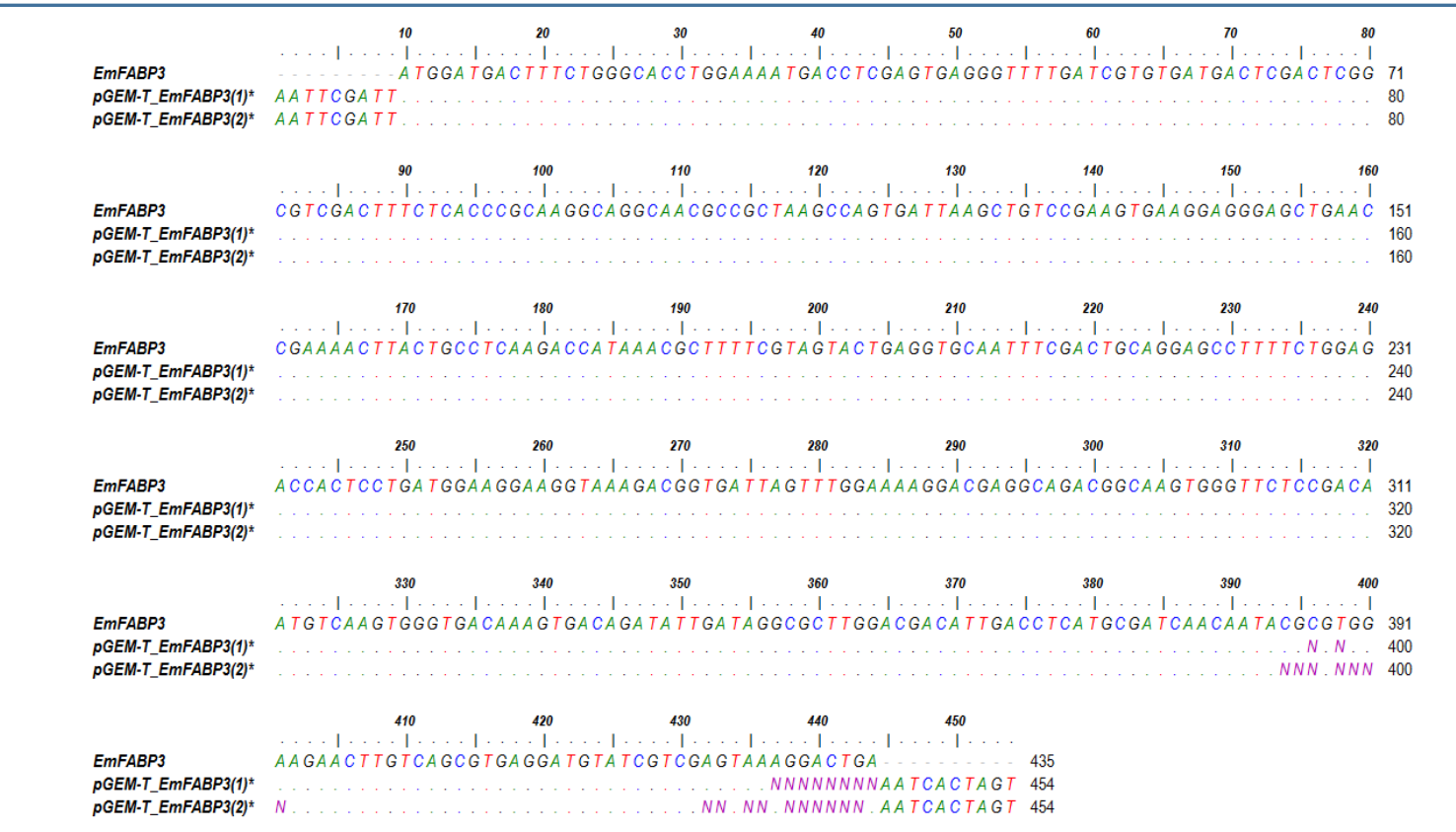

Figura A-7. Verificación de la secuencia del inserto EmFABP3 subclonado en el plásmido pGEM-T Easy. Las coincidencias entre ambas secuencias se muestran con puntos (.). Las primeras y últimas bases en las líneas de la secuenciación corresponden a bases del vector. Se secuenciaron dos clones.

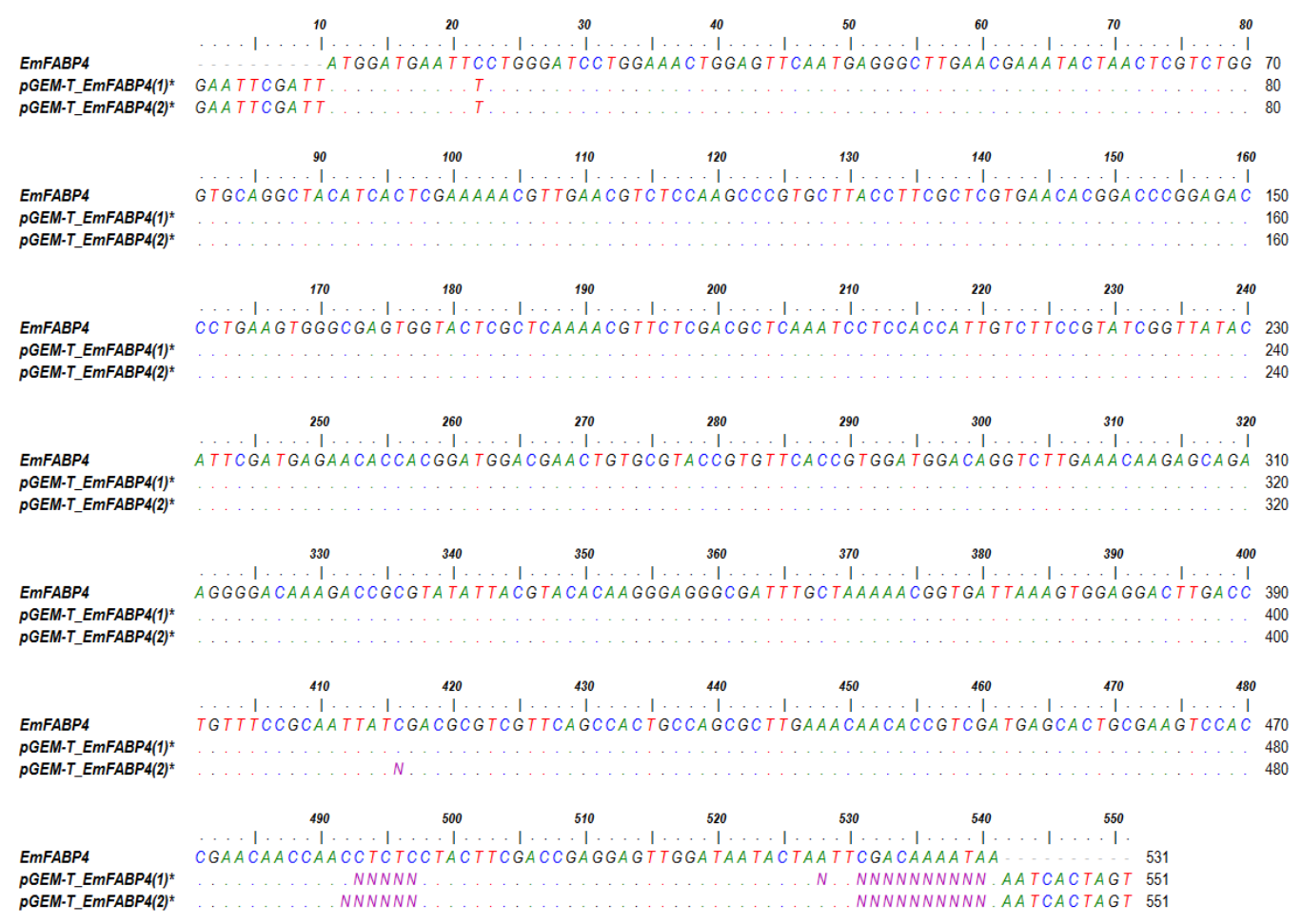

Figura A-8. Verificación de la secuencia del inserto EmFABP4 subclonado en el plásmido pGEM-T Easy. Las coincidencias entre ambas secuencias se muestran con puntos (.). Las primeras y últimas bases en las líneas de la secuenciación corresponden a bases del vector. Se secuenciaron dos clones. 


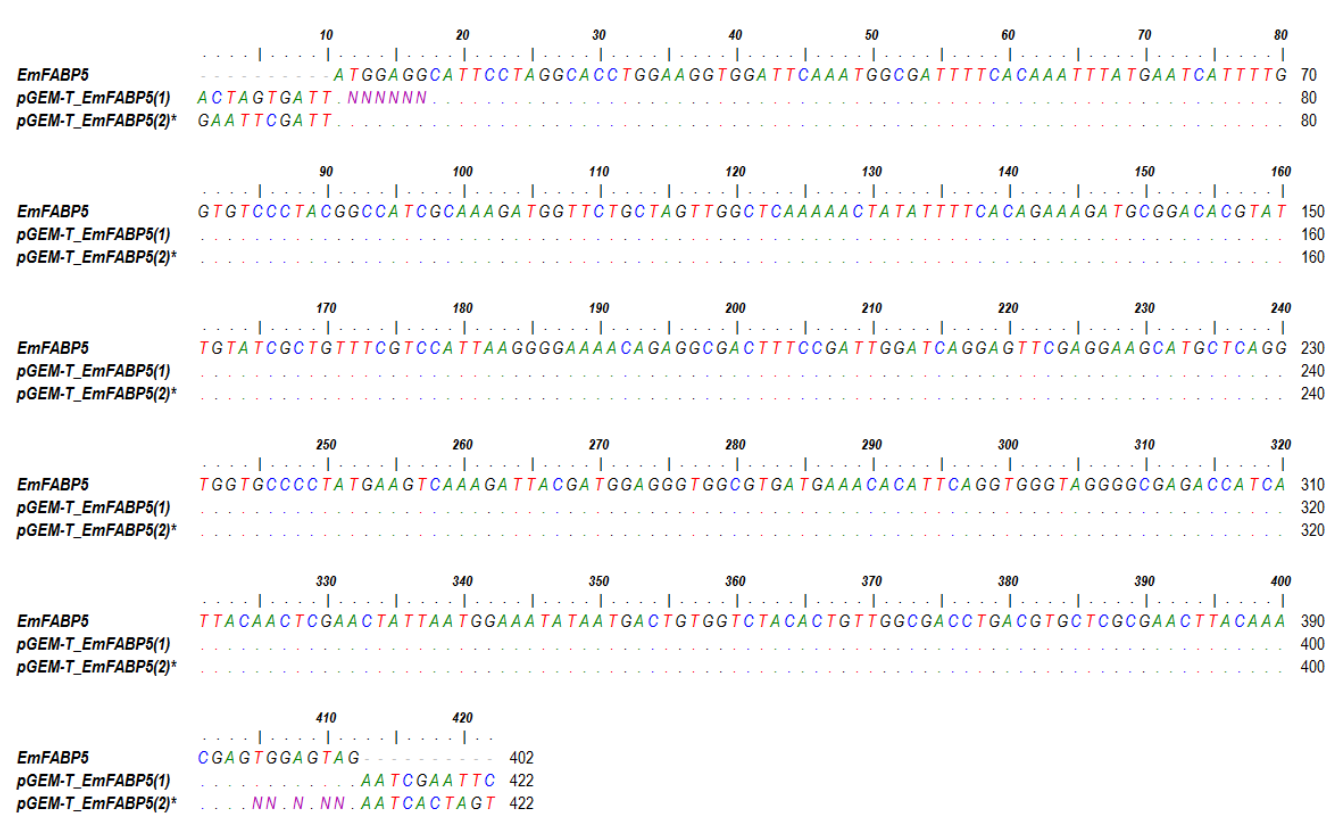

Figura A-9. Verificación de la secuencia del inserto EmFABP5 subclonado en el plásmido pGEM-T Easy. Las coincidencias entre ambas secuencias se muestran con puntos (.). Las primeras y últimas bases en las líneas de la secuenciación corresponden a bases del vector. Se secuenciaron dos clones, en cada uno de los cuales el inserto quedo clonado en sentido inverso, por lo que se tienen secuenciadas las dos hebras. Esto permite confirmar la secuencia predicha. 


\subsection{Obtención y caracterización de anticuerpos policlonales $\alpha$-EgFABP1}

\subsubsection{Materiales y métodos empleados}

\subsubsection{Inmunización y obtención de los sueros}

Para la generación de los anticuerpos a-EgFABP1 se contó con la colaboración del personal de la Cátedra de Producción Animal de la Facultad de Ciencias Agrarias y Forestales de la Universidad Nacional de La Plata. Brevemente, el protocolo consistió en inocular tres conejos de aproximadamente $1,9 \mathrm{~kg}$ de peso con 500 $\mathrm{\mu g}$ de EgFABP1 recombinante en Adyuvante Completo de Freund (Sigma Aldrich). Para la preparación de la mezcla a inocular se colocó el Adyuvante Completo de Freund en un tubo y luego se le agregó un volumen de la solución de EgFABP1 agitando exhaustivamente en vortex, de modo de generar una emulsión. Con la finalidad de evaluar la respuesta inmune de los conejos contra la proteína inoculada se extrajeron muestras de sangre aproximadamente un mes y medio después de la inoculación, y luego se realizaron varias extracciones por un plazo de cuatro meses. También se colectaron muestras de un conejo control, no inmunizado. El título de anticuerpos $\alpha-$ EgFABP1 en suero se determinó por ELISA (Ver ítem siguiente). Pasados los cuatro meses post-inoculación, los conejos fueron sangrados "a blanco". Para la obtención de los sueros a partir de las muestras de sangre, se incubo a esta última durante una hora a $37^{\circ} \mathrm{C}$ en tubos de centrífuga tipo Falcon, seguido de una incubación $\mathrm{ON}$ a $4^{\circ} \mathrm{C}$. Posteriormente, se centrifugaron las muestras a $3000 \mathrm{rpm}$ durante $5 \mathrm{~min}$ a $4^{\circ} \mathrm{C}$ empleando una centrífuga refrigerada Avanti JE. Se separaron los sueros, se alicuotaron, y se conservaron a $-20^{\circ} \mathrm{C}$ hasta su posterior uso.

\subsubsection{Determinación del título del antisuero por ELISA}

La determinación del título de anticuerpos de los sueros se determinó empleando un enzimoinmunoensayo, o ELISA (del inglés de Enzyme-Linked ImmunoSorbent Assay). Para los ELISAs se emplearon placas MaxiSorp ${ }^{\circledR}$ de 96 pocillos, de fondo plano (Nunc). La

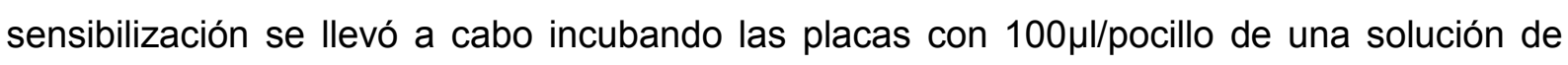
EgFABP1 $\left(5 \mu \mathrm{g} / \mathrm{ml}\right.$ en buffer PBS) a $4^{\circ} \mathrm{C}$, ON. Seguidamente, se bloquearon las placas agregándoles $200 \mu \mathrm{l} /$ pocillo de PBS-Leche (buffer PBS $+2 \%$ leche en polvo descremada) e incubándolas 1 hora a $37^{\circ} \mathrm{C}$. Luego, se lavaron exhaustivamente con PBS-Tween (buffer PBS $+0,05 \%$ Tween 20). Posteriormente, se sembraron 100 $\mu$ l/pocillo de diluciones seriadas del suero en PBS-Leche, y se incubó durante 2 horas a $37^{\circ} \mathrm{C}$. Luego de varios lavados (al menos 
cinco) con PBS-Tween, se agregaron $100 \mu \mathrm{l} /$ pocillo de un anticuerpo de cabra $\alpha$-lgG de conejo, conjugado a peroxidasa (Sigma Aldrich), diluído en PBS-Leche. Dicha mezcla se incubó durante 1 hora a $37^{\circ} \mathrm{C}$, y luego se lavó nuevamente con PBS-Tween. Para el revelado, se

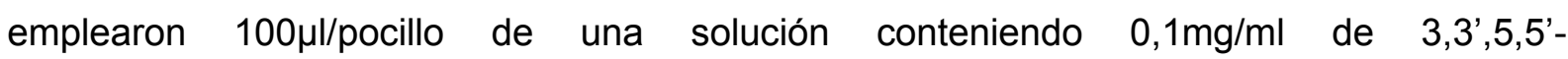
tetrametilbenzidina, o TMB (Sigma Aldrich); y 0,03\% $\mathrm{H}_{2} \mathrm{O}_{2}$ en buffer fosfato/citrato (pH 5). El TMB se incorporó a partir de un stock fresco de $10 \mathrm{mg} / \mathrm{ml}$ TMB en ácido acético al $50 \%$. La placa, conteniendo el sustrato, se incubo durante $30 \mathrm{~min}$ a temperatura ambiente, y protegida de la luz. La reacción se detuvo agregando $50 \mu \mathrm{l} /$ pocillo de $1 \mathrm{M} \mathrm{H}_{2} \mathrm{SO}_{4}$. Finalmente, se registró la absorbancia a 450nm empleando un lector de placas DTX 880 (Beckman Coulter). Dicha absorbancia se corrigió con la absorbancia a 595nm.

\subsubsection{Caracterización del antisuero por Western-Blot}

La caracterización de los anticuerpos policlonales obtenidos según se describió en el ítem 7.4.1 se llevó a cabo por Western-Blot. Para ello, se utilizaron muestras de EgFABP1 recombinante purificada, protoescólices de E. granulosus, y screenings de expresión de EgFABP1 y EgFABP2 recombinantes. Para los Western-Blots se realizaron, previamente, SDS-PAGE conteniendo diferentes muestras: varias concentraciones de EgFABP1 recombinante; $5 \mu$ l de una suspensión de protoescólices de $E$. granulosus hervidos en el buffer de siembra descripto en el ítem 2.1.2.2; o las proteínas provenientes de screenings de expresión realizados en $E$. coli BL21(DE3) conteniendo los plásmidos $p E T-11 b$-egfabp1 o $p E T$-5a-egfabp2, tal como se describió en el ítem 2.1.2.1. Como marcador de peso molecular para la electroforesis, y como control de la transferencia, se empleó el marcador coloreado Full-Range Rainbow Molecular Weight Marker (GE Healthcare Life Sciences). Una vez llevada a cabo la electroforesis de las muestras, se realizó la transferencia de las mismas a membranas de fluoruro de polivinilideno (Pierce), o PVDF por sus siglas en inglés, empleando un equipo de transferencia húmeda Mini Trans-Blot (BioRad). El buffer de transferencia utilizado fue $25 \mathrm{mM}$ Tris- $\mathrm{HCl}, 192 \mathrm{mM}$ Glicina, 20\% Metanol, pH 8,3. La transferencia se realizó a 100V durante una hora. Seguidamente, se bloquearon las membranas incubándolas ON a $4^{\circ} \mathrm{C}$ con solución de bloqueo 5\%: $5 \mathrm{~g}$ de BSA (Sigma Aldrich) en buffer PBS-Tween. Al día siguiente, se incubaron las membranas durante una hora a temperatura ambiente con una dilución 1:25000 del suero a-EgFABP1 (preparada en solución de BSA al 1\% preparada en buffer PBS-Tween). Posteriormente se realizaron 5 lavados de 5 minutos cada uno con buffer PBS-Tween, y luego se realizó una incubación de una hora con una dilución 1:5000 (preparada de igual modo que la del anticuerpo primario) de anticuerpos de cabra, $\alpha$-conejo, conjugados a peroxidasa (Sigma Aldrich). Seguidamente, se repitieron los lavados con buffer PBS-Tween. Para el revelado se empleó el reactivo SuperSignal West Pico Chemiluminescent 
Substrate (Pierce) según las indicaciones del fabricante. El registro de los resultados se llevó a cabo empleando un equipo de digitalización de imágenes ImageQuant 350 (GE Healthcare Life Sciences). Durante mi estadía en el laboratorio del Dr. Brehm se evaluó también la respuesta de los anticuerpos policlonales $\alpha$-EgFABP1 frente a muestras de $E$. multilocularis. Para ello, se separaron por SDS-PAGE 2,5 $\mathrm{g}$ de proteínas de un extracto de células en cultivo de E. multilocularis y se sometieron a Western Blot, revelando con los anticuerpos a-EgFABP1 (el procedimiento se detalla en el ítem 2.4.5.2, aunque no difiere demasiado de lo antes descripto).

\subsubsection{Resultados obtenidos}

\subsubsection{Caracterización de anticuerpos policlonales $\alpha$-EgFABP1}

Como se mencionó previamente, una vez extraída la sangre de los conejos y separados los sueros, se realizó un pool de todos los sueros y se les determinó el título mediante ELISA. El valor obtenido para el título fue de $1,2 \times 10^{7}$, expresado como el inverso de la última dilución que produjo un valor de DO mayor al del blanco.

Posteriormente, se realizaron diversos Western Blots para caracterizar la especificidad de los anticuerpos. Tal como se puede apreciar en la Figura A-10, los anticuerpos policlonales obtenidos son capaces de reconocer a EgFABP1 recombinante purificada y, lo que es más importante, es capaz de detectar una banda única de proteína de tamaño adecuado en un extracto de protoescólices de E. granulosus.

Por otro lado, cuando se realizó un Western Blot contra extractos de proteínas de E. coli BL21 (DE3) transformadas con plásmidos para la expresión de EgFABP1 (pET11b-egfabp1) - EgFABP2 (pET5a-egfabp2), e inducidas con IPTG, se observó que los anticuerpos policlonales $\alpha$-EgFABP1 son capaces de detectar también a EgFABP2. Asimismo, el suero reconoció múltiples bandas de proteínas propias de la bacteria. Es posible que dichas proteínas hayan sido contaminantes minoritarios en la preparación de EgFABP1 purificada con la que se inmunizaron los conejos, por lo que puede haber en el suero anticuerpos que las reconozcan. Cabe destacar también que la cantidad de proteínas en el extracto de $E$. coli ha sido seguramente muy alto, puesto que la banda correspondiente a EgFABP1 también es muy intensa.

Por su parte, tal como se mencionó anteriormente, durante mi estadía en el laboratorio del Dr. Brehm se evaluó también la capacidad de los anticuerpos a-EgFABP1 de reconocer a las FABPs de E. multilocularis. En la Figura A-11, puede verse que en los extractos de proteínas de células de E. multilocularis los anticuerpos a-EgFABP1 detectaron una única banda de proteínas, con un peso molecular acorde a lo esperado. 

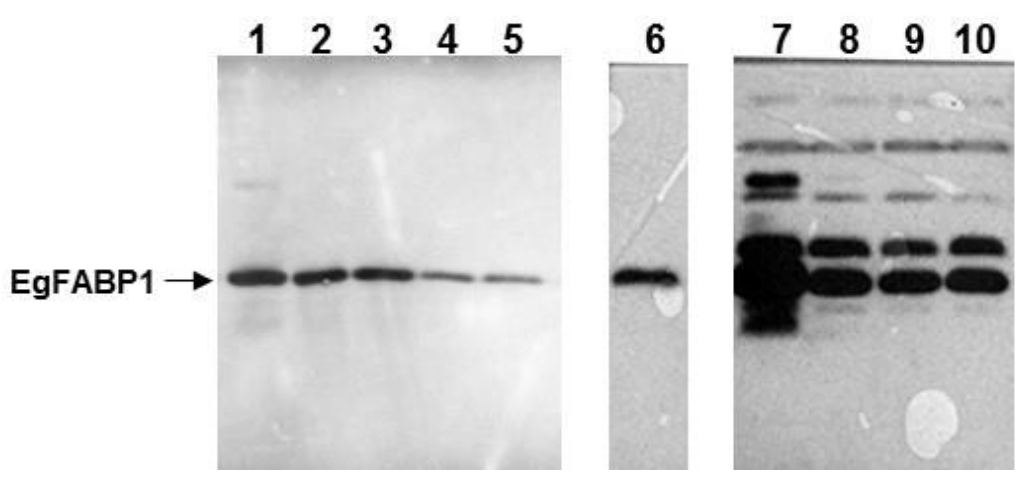

Figura A-10. Caracterización de los anticuerpos policlonales antiEgFABP1 por Western Blot. Las figuras muestran Western Blots realizados contra diferentes muestras, utilizando una dilución del suero

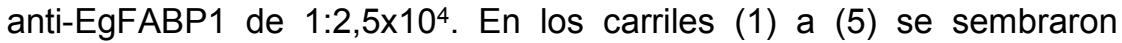
distintas cantidades de EgFABP1 recombinante purificada: $5 \mu \mathrm{g} ; 1 \mu \mathrm{g}$; $0,5 \mu \mathrm{g} ; 0,1 \mu \mathrm{g}$ y $0,05 \mu \mathrm{g}$. El carril (6) corresponde a un Western Blot realizado contra un extracto de proteínas de protoescólices de $E$. granulosus. En los carriles (7) a (10) se sembraron extractos de proteínas de E. coli inducidas para la producción de EgFABP1 recombinante (carril 7) o EgFABP2 recombinante (carriles 8 a 10).

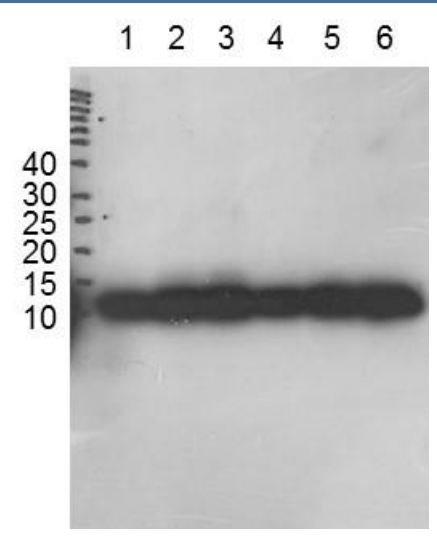

Figura A-11. Western Blot de muestras de proteínas de $E$. multilocularis. Para el Western Blot mostrado en la figura se utilizó una dilución del suero $\alpha$-EgFABP1 de 1:10000. En los carriles 1-3 y 4-6 se sembraron cantidades crecientes de dos muestras de proteínas totales de células en cultivo de E. multilocularis. Las células habían sido cultivadas por dos semanas. La cantidad total de proteínas sembradas en cada carril fue de aproximadamente $2,5 \mu \mathrm{g}(1$ y 4$) ; 5 \mu \mathrm{g}(2$ y 5 ) y $7,5 \mu \mathrm{g}$ (3 y 6). A la izquierda se indican los pesos moleculares (en $\mathrm{kDa}$ ) de las bandas correspondientes al marcador de peso molecular. 


\subsection{Inmunolocalización de FABPs en Echinococcus spp.}

A continuación se presentan ensayos preliminares de inmunolocalización de FABPs en muestras de E. granulosus y E. multilocularis.

\subsubsection{Materiales y métodos empleados}

\subsubsection{Inmunofluorescencia en protoescólices in toto de E. granulosus}

Para la detección de las FABPs de E. granulosus por inmunofluorescencia, se emplearon protoescólices provenientes de quistes bovinos que se mantuvieron durante dos meses en cultivo en medio DMEM con gentamicina en el laboratorio de la Dra. Rosenzvit (IMPAM, UBACONICET). La semana anterior a la fijación se incorporó al medio de cultivo $10 \%$ de suero fetal bovino. El protocolo de inmunolocalización se inició con el lavado de los protoescólices con PBS, seguido de lavados con el buffer de permeabilización (Buffer PBS con el agregado de 0,35\% Tritón X-100; 0,50\% dimetilsulfóxido (DMSO); 0,10\% $\mathrm{NaN}_{3} ; 0,10 \% \mathrm{BSA} ; 6,25 \times 10^{-3}$ \% Digitonina) (Camicia et al., 2013). Luego de los lavados, los protoescólices se fijaron incubándolos durante 4 horas a temperatura ambiente en una solución de paraformaldehído (PAF) al 4\%. Seguidamente, los protoescólices fijados se lavaron con Etanol $70 \%$ y se almacenaron en Etanol $100 \%$ a $4^{\circ} \mathrm{C}$ hasta su posterior uso. Los protoescólices se rehidrataron, y se lavaron con el buffer de permeabilización. Posteriormente, se incubaron los protoescólices durante 96 horas con la dilución de anticuerpos que correspondiera, preparada en el buffer de permeabilización. Las diluciones ensayadas fueron 1/100, 1/500, 1/1000 y 1/5000. Se emplearon $30 \mu l$ de la suspensión de protoescólices por tratamiento. Luego de un lavado de 24 horas con el buffer de permeabilización, se incubaron las muestras durante 24 horas con una dilución 1/500 de anticuerpos $\alpha$-lgG de conejo conjugados a isotiocianato de fluoresceína (FITC; Invitrogen), preparada en buffer de permeabilización. Seguidamente, se realizaron tres lavados sucesivos con PBS, y se realizó el montaje de las muestras. Para ello, se colocaron $20 \mu \mathrm{l}$ de glicerol $80 \%$ sobre un portaobjetos, seguido de $20 \mu \mathrm{l}$ de la muestra correspondiente. Se mezcló bien la muestra de protoescólices con el glicerol, se colocó un cubreobjetos, y se sellaron los bordes con esmalte. Como control, se incluyeron muestras tratadas con anticuerpos a-serotonina (dilución 1/1000, como control positivo), muestras tratadas con anticuerpos $\alpha-E g F A B P 1$, sin anticuerpo secundario (y viceversa); y muestras tratadas con suero de conejo no inmunizado, como control negativo. El ensayo fue realizado con la asistencia del Dr. Federico Camicia (IMPAM, UBA-CONICET). Las imágenes de 
microscopía confocal se obtuvieron en el servicio de microscopía de la Facultad de Ciencias Veterinarias de la UNLP.

\subsubsection{Inmunohistoquímica en cortes de vesículas de E. multilocularis obtenidas in vitro}

Para la detección por inmunohistoquímica de FABPs en el metacestodo de $E$. multilocularis, se utilizaron cortes en parafina de vesículas de E. multilocularis obtenidas in vitro (según Brehm \& Spiliotis, 2008; Spiliotis \& Brehm, 2009), gentilmente cedidas por el Dr. Uriel Koziol. Para ello, los cortes se desparafinaron mediante dos inmersiones sucesivas (de 5 minutos cada una) de los mismos en xilol. Seguidamente, los cortes se rehidrataron mediante inmersiones secuenciales, de dos minutos cada una, en etanol $100 \%$, etanol $75 \%$ PBS, etanol 50\%-PBS y etanol 25\%-PBS. Luego, se realizaron dos lavados (de 5 minutos cada uno) en buffer PBS. Con la finalidad de eliminar la actividad peroxidasa intrínseca a la muestra, se incubaron las mismas durante 10 minutos en una solución de $\mathrm{H}_{2} \mathrm{O}_{2}$ al $3 \%$ en PBS. Pasado dicho tiempo, se lavaron las muestras con PBS durante 5 minutos, y se permeabilizaron mediante dos incubaciones consecutivas en una solución $0,1 \%$ Triton $X-100$ en PBS ( 5 minutos cada una). Posteriormente, se llevó a cabo un procedimiento de bloqueo incubando las muestras durante una hora en una solución compuesta por PBS conteniendo $1 \%$ BSA, $5 \%$ de suero de oveja (Sigma Aldrich) y 0,05\% Tween-20. La incubación con el anticuerpo primario se realizó $\mathrm{ON}$ a $4^{\circ} \mathrm{C}$, cubriendo el portaobjetos con Parafilm ${ }^{\circledR}$, de modo de generar una cámara húmeda. La dilución de anticuerpo empleada fue de 1/2000 y se realizó en PBS conteniendo 1\% BSA. Se realizó un control en paralelo, incubando una muestra con $\mathrm{PBS} / 1 \% \mathrm{BSA}$. Al día siguiente, se hicieron 4 lavados de 15 minutos cada uno en PBS. Luego, se incubaron las muestras durante 2 horas con el anticuerpo secundario $\alpha$-conejo conjugado a peroxidasa (diluído $1 / 500$ en $\mathrm{PBS} / 1 \%$ BSA) a temperatura ambiente, cubriendo los portaobjetos con Parafilm ${ }^{\circledR}$. Una vez cumplido el tiempo de incubación, se realizaron 4 lavados de 15 minutos cada uno en PBS. A continuación, se realizó una incubación de 2 minutos en una solución $50 \mathrm{mM}$ de Acetato de Sodio ( $\mathrm{pH}$ 5). Finalmente, se reveló empleando el reactivo 3-amino-9-etilcarbazol (AEC, Sigma Aldrich). Se empleó $1 \mathrm{ml}$ de solución de AEC (preparada según indicaciones del fabricante) por cada portaobjetos. Las muestras se tiñeron también con una solución $1 \mu \mathrm{g} / \mathrm{ml}$ de 4',6-diamidino-2-fenilindol (DAPI) preparada en PBS, incubándolas durante 10 minutos protegidas de la luz. Posteriormente, se realizaron dos lavados de 10 minutos cada uno en PBS. Finalmente, para el montaje de los preparados se utilizó Fluoprep (Biomerieux), se dejó secar los preparados durante 15 minutos, y se conservaron a $4^{\circ} \mathrm{C}$ protegidos de la luz. 


\subsubsection{Resultados obtenidos}

\subsubsection{Inmunofluorescencia en protoescólices in toto de E. granulosus}

Debido a la escasa información disponible en relación a la localización de las FABPs en protoescólices de E. granulosus (Esteves et al., 1993), se buscó realizar inmunofluorescencias en protoescólices enteros (in toto) para complementar lo ya descripto. En la Figura A-12 se muestran imágenes de los resultados. Dado que la morfología de los protoescólices se hallaba alterada, no se pudieron establecer conclusiones certeras acerca de la localización de EgFABP1. La incubación de los protoescólices con suero de conejo no inmunizado mostró solo algo de tinción inespecífica en los ganchos del rostelo, mientras que el control positivo con anticuerpos $\alpha$-serotonina permitió detectar los ganglios, aunque su morfología se hallaba también alterada (Camicia et al., 2013). La tinción con anticuerpos a-EgFABP1 por su parte, aunque no haya permitido obtener demasiadas conclusiones respecto a su localización, presentó una señal distribuida en gran parte del protoescólex.

A

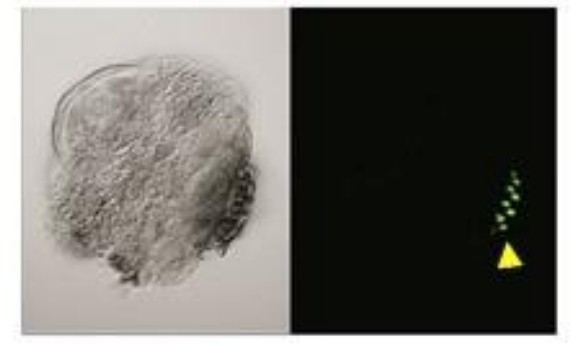

B

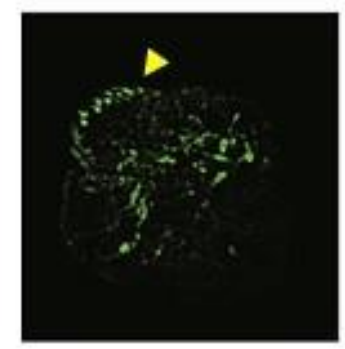

C

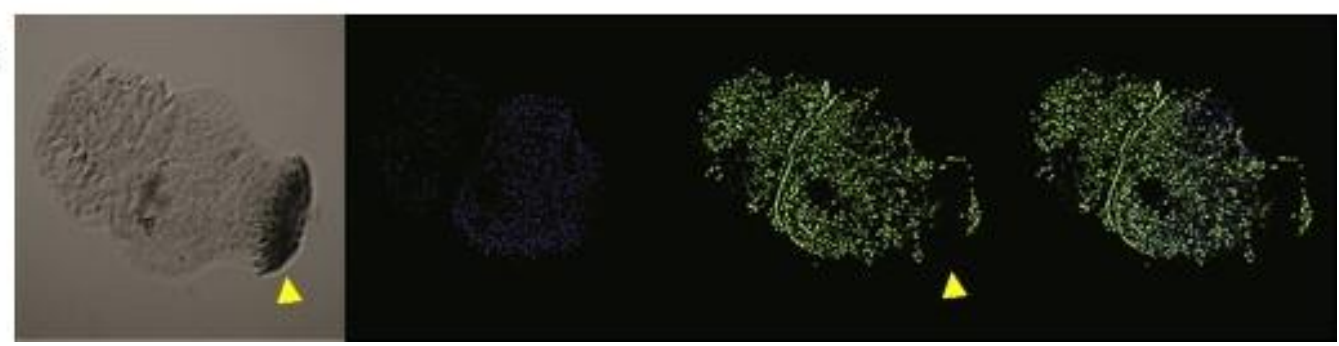

Figura A-12. Inmunofluorescencias in toto en protoescólices de $E$. granulosus. En el panel A se muestra la imagen de un protoescólex observado con luz visible (izquierda) y la tinción, inespecífica, obtenida al tratar dicho espécimen con suero de un conejo no inmunizado (dilución 1/50). La fluorescencia corresponde al FITC conjugado al anticuerpo secundario anticonejo. En el panel B se observa un protoescólex tratado con anticuerpo anti-serotonina (dilución 1/1000). En el panel $C$ se pueden ver diferentes imágenes correspondientes a un protoescólex tratado con anticuerpos anti-EgFABP1 (dilución 1/1000). De izquierda a derecha se muestra el protoescólex observado con luz visible, los núcleos teñidos con DAPI (azul), la señal correspondiente al anticuerpo secundario conjugado a FITC (verde), y la superposición de las señales de DAPI + FITC. Las puntas de flecha (en amarillo) señalan el rostelo de los protoescólices como referencia espacial. 
Cabe destacar que, tal como se observó al caracterizar el suero $\alpha$-EgFABP1, el mismo es capaz de reconocer tanto a EgFABP1 como a EgFABP2, pero no se tiene información acerca de la capacidad del anticuerpo de detectar a alguna de las otras FABPs de E. granulosus. Como se mencionó previamente, existe evidencia de que EgFABP3, aparte de EgFABP1, se expresa a nivel proteico en dicho estadio del parásito (Lic. Maite Folle, UdelaR, comunicación personal). Los datos transcriptómicos, por otra parte, indican transcripción de varios de los genes de las FABPs en protoescólices, aunque las proteínas podrían no estar traducidas. Por lo tanto, con los datos disponibles en la actualidad es difícil discernir si la señal obtenida corresponde sólo a EgFABP1, a alguna de las otras EgFABPs, o a varias. La relativa escasez de material parasitario dificultó la continuidad de estos ensayos, aunque los mismos deberían ser continuados, de ser posible con anticuerpos que diferencien las distintas FABPs. De este modo podría obtenerse información que permita aproximarse mejor a las posibles funciones de estas proteínas en la biología del parásito.

\subsubsection{Inmunohistoquímica en cortes de vesículas de $E$. multilocularis obtenidas in vitro}

Dado que no existía ninguna evidencia reportada sobre la presencia de FABPs en $E$. multilocularis, se realizó un ensayo de inmunohistoquímica en cortes de vesículas de $E$. multilocularis obtenidas en cultivo. Tal como se mencionó previamente, dichos preparados fueron gentilmente cedidos por el Dr. Uriel Koziol (Universidad de Wurzburgo, Alemania).

Tal como se puede observar en la Figura $A-13$, las FABPs estarían localizadas principalmente en la región de la capa germinativa en contacto con el líquido hidático, lo cual lleva a pensar que las mismas podrían estar involucradas en el intercambio de ácidos grasos entre el interior de las células y el líquido hidático. Sin embargo, dado que, por analogía con lo que ocurre en E. granulosus, el anticuerpo podría reconocer más de una FABP, se necesitarían estudios más detallados para profundizar en la localización diferencial de cada una de las FABPs. Asimismo, dado que la capa germinativa es una estructura muy compleja, sería deseable poder determinar en qué tipo celular en particular se expresan las diferentes FABPs. 
A
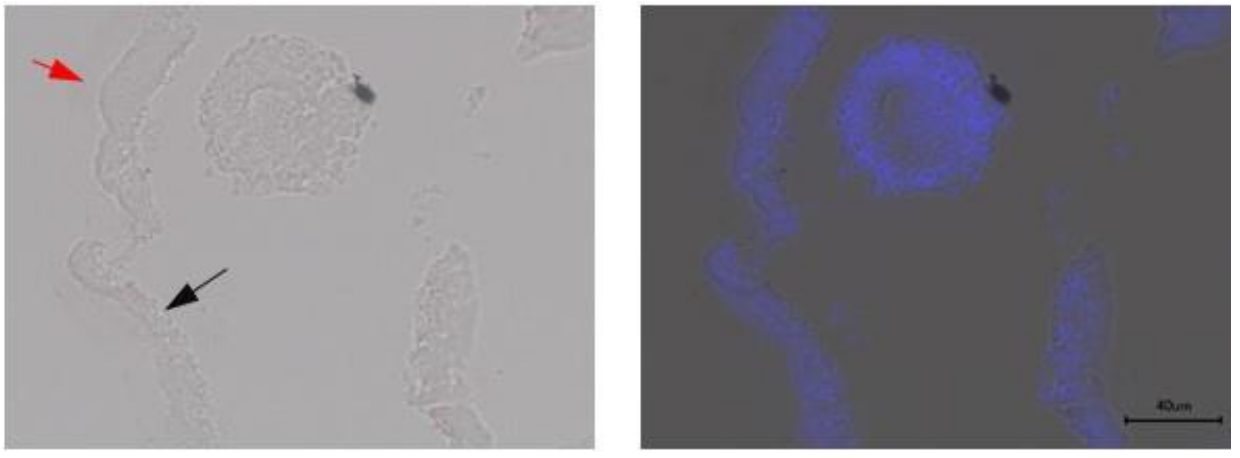

B
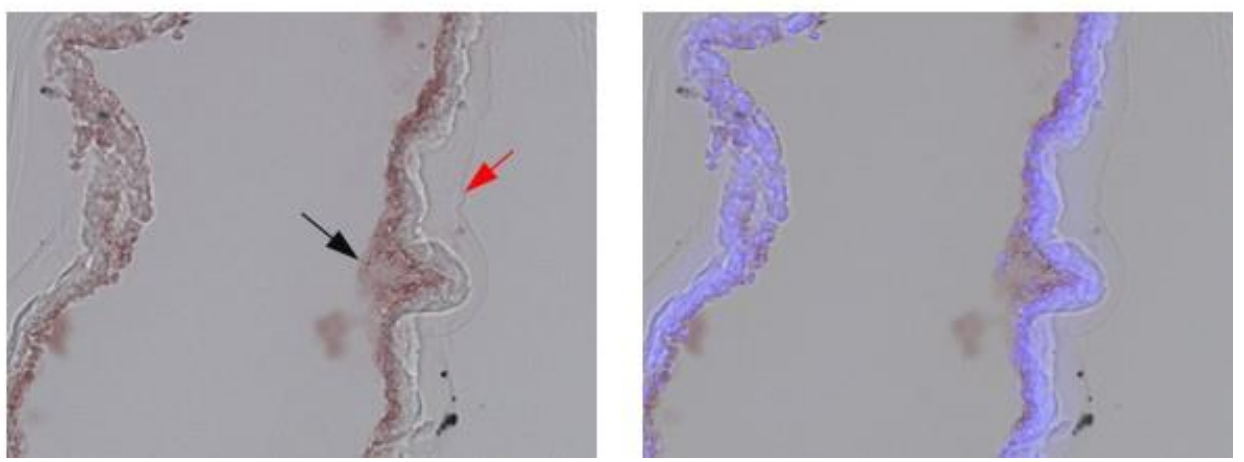

Figura A-13. Imnunohistoquímica en cortes de vesículas de $E$. multilocularis obtenidas in vitro. En el panel A se observa el control sin anticuerpo primario y en el $\mathrm{B}$, la localización de las FABPs (marrón) en el corte de vesícula de E. multilocularis. A la izquierda se muestra la imagen obtenida con luz visible, y a la derecha la superposición de dicha imagen con la fluorescencia azul correspondiente a los núcleos teñidos con DAPI. Las flechas negras señalan la capa germinativa de E. multilocularis, mientras que las flechas rojas indican la zona correspondiente a la capa laminar (acelular). Las imágenes fueron obtenidas utilizando un objetivo de 20x. 


\section{BIBLIOGRAFÍA}

Alvarez Rojas, C.A., Romig, T., Lightowlers, M.W., 2014. Echinococcus granulosus sensu lato genotypes infecting humans - review of current knowledge. Int. J. Parasitol. 44, 918.

Alvite, G., Di Pietro, S.M., Santomé, J.A., Ehrlich, R., Esteves, A., 2001. Binding properties of Echinococcus granulosus fatty acid binding protein. Biochim. Biophys. Acta 1533, 293302.

Alvite, G., Esteves, A., 2012. Lipid binding proteins from parasitic platyhelminthes. Front. Physiol. 3.

Arighi, C.N., Rossi, J.P.F.C., Delfino, J.M., 2003. Temperature-induced conformational switch in intestinal fatty acid binding protein (IFABP) revealing an alternative mode for ligand binding. Biochemistry 42, 7539-7551.

Armstrong, E.H., Goswami, D., Griffin, P.R., Noy, N., Ortlund, E. a, 2014. Structural basis for ligand regulation of the Fatty Acid Binding Protein 5, Peroxisome Proliferator Activated Receptor $\beta / \delta$ (FABP5-PPAR $\beta / \delta$ ) signaling pathway. J. Biol. Chem.

Bai, Y., Zhang, Z., Jin, L., Kang, H., Zhu, Y., Zhang, L., Li, X., Ma, F., Zhao, L., Shi, B., Li, J., McManus, D.P., Zhang, W., Wang, S., 2014. Genome-wide sequencing of small RNAs reveals a tissue-specific loss of conserved microRNA families in Echinococcus granulosus. BMC Genomics 15, 736.

Becker, M.M., Kalinna, B.H., Waine, G.J., McManus, D.P., 1994. Gene cloning, overproduction and purification of a functionally active cytoplasmic fatty acid-binding protein (Sj-FABPC) from the human blood fluke Schistosoma japonicum. Gene 148, $321-325$.

Bernlohr, D.A., Simpson, M.A., Vogel Hertzel, A., Banaszak, L.J., 1997. Intracellular lipidbinding proteins and their genes. Annu. Rev. Nutr. 17, 277-303.

Brehm, K., Spiliotis, M., 2008. Recent advances in the in vitro cultivation and genetic manipulation of Echinococcus multilocularis metacestodes and germinal cells. Exp. Parasitol. 119, 506-515.

Brehm, K., Wolf, M., Beland, H., Kroner, A., Frosch, M., 2003. Analysis of differential gene expression in Echinococcus multilocularis larval stages by means of spliced leader differential display, in: International Journal for Parasitology. pp. 1145-1159.

Brownlee, D.J., Fairweather, I., Johnston, C.F., Rogan, M.T., 1994. Immunocytochemical localization of serotonin (5-HT) in the nervous system of the hydatid organism, Echinococcus granulosus (Cestoda, Cyclophyllidea). Parasitology 109, 233-241.

Brusca, R.C., Brusca, G.J., 2003. Invertebrates. Sinauer Associates.

Cai, H., Liu, Q., Gao, D., Wang, T., Chen, T., Yan, G., Chen, K., Xu, Y., Wang, H., Li, Y., Zhu, W., 2015. Novel fatty acid binding protein 4 (FABP4) inhibitors: virtual screening, synthesis and crystal structure determination. Eur. J. Med. Chem. 90, 241-250. 
Camicia, F., Herz, M., Prada, L.C., Kamenetzky, L., Simonetta, S.H., Cucher, M., Bianchi, J.I., Fernandez, C., Brehm, K., Rosenzvit, M.C., 2013. The nervous and prenervous roles of serotonin in Echinococcus spp. Int. J. Parasitol. 43, 647-659.

Chen, J., Wang, J., Zhu, W., 2014. Binding modes of three inhibitors 8CA, F8A and I4A to AFABP studied based on molecular dynamics simulation. PLoS One 9, e99862.

Conant, G.C., Wolfe, K.H., 2008. Turning a hobby into a job: how duplicated genes find new functions. Nat. Rev. Genet. 9, 938-950.

Córsico, B., Cistola, D.P., Frieden, C., Storch, J., 1998. The helical domain of intestinal fatty acid binding protein is critical for collisional transfer of fatty acids to phospholipid membranes. Proc. Natl. Acad. Sci. U. S. A. 95, 12174-12178.

Córsico, B., Falomir-Lockhart, L.J., Franchini, G.R., Scaglia, N. (Eds.), 2013. Análisis estructural y funcional de Macromoléculas, $1^{\circ}$ Edición. ed. EDULP - Universidad Nacional de La Plata, La Plata.

Córsico, B., Franchini, G.R., Hsu, K., Storch, J., 2005. Fatty acid transfer from intestinal fatty acid binding protein to membranes: electrostatic and hydrophobic interactions. J. Lipid Res. 46, 1765-1772.

Córsico, B., Liou, H.L., Storch, J., 2004. The a-Helical Domain of Liver Fatty Acid Binding Protein Is Responsible for the Diffusion-Mediated Transfer of Fatty Acids to Phospholipid Membranes. Biochemistry 43, 3600-3607.

Crompton, D.W.T. (Ed.), 2013. Sustaining the drive to overcome the global impact of neglected tropical diseases. Second WHO report on neglected tropical diseases. World Health Organization, Geneva.

Cronan, J.E., Rock, C.O., 1994. The presence of linoleic acid in Escherichia coli cannot be confirmed. J. Bacteriol. 176, 3069-3071.

Cucher, M., Macchiaroli, N., Kamenetzky, L., Maldonado, L., Brehm, K., Rosenzvit, M., 2015. High-throughput characterization of Echinococcus spp. metacestode miRNomes. Int. J. Parasitol. 45, 253-267.

Cucher, M., Prada, L., Mourglia-Ettlin, G., Dematteis, S., Camicia, F., Asurmendi, S., Rosenzvit, M., 2011. Identification of Echinococcus granulosus microRNAs and their expression in different life cycle stages and parasite genotypes. Int. J. Parasitol. 41, 439-448.

D'Alessandro, A., Rausch, R.L., 2008. New aspects of neotropical polycystic (Echinococcus vogeli) and unicystic (Echinococcus oligarthrus) echinococcosis. Clin. Microbiol. Rev. $21,380-401$.

De Gerónimo, E., Hagan, R.M., Wilton, D.C., Córsico, B., 2010. Natural ligand binding and transfer from liver fatty acid binding protein (LFABP) to membranes. Biochim. Biophys. Acta 1801, 1082-1089.

Díaz, A., Casaravilla, C., Irigoín, F., Lin, G., Previato, J.O., Ferreira, F., 2011. Understanding the laminated layer of larval Echinococcus I: structure. Trends Parasitol. 27, 204-213. 
Digenis, G.A., Thorson, R.E., Konyalian, A., 1970. Cholesterol biosynthesis and lipid biochemistry in the scolex of Echinococcus granulosus. J. Pharm. Sci. 59, 676-679.

Eckert, J., Gemmel, M., Meslin, F., Pawlowski, Z. (Eds.), 2001. WHO/OIE Manual on Echinococcosis in Humans and Animals: a Public Health Problem of Global Concern, 1 st ed. World Organisation for Animal Health, Paris, France.

Espínola, S.M., Ferreira, H.B., Zaha, A., 2014. Validation of suitable reference genes for expression normalization in Echinococcus spp. larval stages. PLoS One 9, e102228.

Esteves, A., Dallagiovanna, B., Ehrlich, R., 1993. A developmentally regulated gene of Echinococcus granulosus codes for a 15.5-kilodalton polypeptide related to fatty acid binding proteins. Mol. Biochem. Parasitol. 58, 215-222.

Esteves, A., Ehrlich, R., 2006. Invertebrate intracellular fatty acid binding proteins. Comp. Biochem. Physiol. Part C 142, 262-274.

Esteves, A., Paulino, M., 2013. In silico studies of Echinococcus granulosus FABPs. J. Biomol. Struct. Dyn. 31, 224-239.

Esteves, A., Portillo, V., Ehrlich, R., 2003. Genomic structure and expression of a gene coding for a new fatty acid binding protein from Echinococcus granulosus. Biochim. Biophys. Acta - Mol. Cell Biol. Lipids 1631, 26-34.

Estuningsih, S.E., Smooker, P.M., Wiedosari, E., Widjajanti, S., Vaiano, S., Partoutomo, S., Spithill, T.W., 1997. Evaluation of antigens of Fasciola gigantica as vaccines against tropical fasciolosis in cattle. Int. J. Parasitol. 27, 1419-28.

Falomir-Lockhart, L.J., Laborde, L., Kahn, P.C., Storch, J., Córsico, B., 2006. ProteinMembrane Interaction and Fatty Acid Transfer from Intestinal Fatty Acid-binding Protein to Membranes. Support for a multistep process. J. Biol. Chem. 281, 13979-13989.

Flower, D.R., 1996. The lipocalin protein family: structure and function. Biochem. J. 318, 114.

Folch, J., Lees, M., Sloane Stanley, G., 1957. A simple method for the isolation and purification of total lipides from animal tissues. J. Biol. Chem. 226, 497-509.

Folli, C., Ramazzina, I., Percudani, R., Berni, R., 2005. Ligand-binding specificity of an invertebrate (Manduca sexta) putative cellular retinoic acid binding protein. Biochim. Biophys. Acta 1747, 229-37.

Fontana, A., Polverino de Laureto, P., Spolaore, B., Frare, E., Picotti, P., Zambonin, M., 2004. Probing protein structure by limited proteolysis. Acta Biochim. Pol. 51, 299-321.

Franchini, G.R., Pórfido, J.L., Ibáñez Shimabukuro, M., Rey Burusco, M.F., Bélgamo, J. a., Smith, B.O., Kennedy, M.W., Córsico, B., 2015. The unusual lipid binding proteins of parasitic helminths and their potential roles in parasitism and as therapeutic targets. Prostaglandins, Leukot. Essent. Fat. Acids 93, 31-36.

Franchini, G.R., Storch, J., Córsico, B., 2008. The integrity of the a-helical domain of intestinal fatty acid binding protein is essential for the collision-mediated transfer of fatty 
acids to phospholipid membranes. Biochim. Biophys. Acta (BBA)-Molecular Cell Biol. Lipids 1781, 192-9.

Frayha, G.J., 1968. A study on the synthesis and absorption of cholesterol in hydatid cysts (Echinococcus granulosus). Comp. Biochem. Physiol. 27, 875-878.

Frayha, G.J., 1974. Synthesis of certain cholesterol precursors by hydatid protoscoleces of Echinococcus granulosus and cysticerci of Taenia hydatigena. Comp. Biochem. Physiol. B 49, 93-98.

Frayha, G.J., Bahr, G.M., Haddad, R., 1980. The Lipids and Phospholipids of Hydatid Protoscolices of Echinococcus granulosus (Cestoda). Int. J. Parasitol. 10, 213-216.

Fromm, B., Worren, M.M., Hahn, C., Hovig, E., Bachmann, L., 2013. Substantial loss of conserved and gain of novel MicroRNA families in flatworms. Mol. Biol. Evol. 30, 26192628.

Furuhashi, M., Hotamisligil, G.S., 2008. Fatty acid-binding proteins: role in metabolic diseases and potential as drug targets. Nat. Rev. Drug Discov. 7, 489-503.

Garofalo, A., Kläger, S.L., Rowlinson, M.C., Nirmalan, N., Klion, A., Allen, J.E., Kennedy, M.W., Bradley, J.E., 2002. The FAR proteins of filarial nematodes: secretion, glycosylation and lipid binding characteristics. Mol. Biochem. Parasitol. 122, 161-170.

Gelmedin, V., Zavala-Góngora, R., Fernandez, C., Brehm, K., 2005. Echinococcus multilocularis: Cloning and characterization of a member of the SNW/SKIP family of transcriptional coregulators. Exp. Parasitol. 111, 115-120.

Gillilan, R., Ayers, S., Noy, N., 2007. Structural basis for activation of fatty acid-binding protein 4. J. Mol. Biol. 372, 1246-1260.

Gomori, G., 1942. A modification of the colorimetric phosphorus determination for use with the photo-electric colorimeter. J. Lab. Clin. Med. 27, 955.

Guarnera, E.A., 2009. Hidatidosis en Argentina: carga de enfermedad, 1st ed. Buenos Aires.

Haunerland, N.H., Chisholm, J.M., 1990. Fatty acid binding protein in flight muscle of the locust, Schistocerca gregaria. Biochim. Biophys. Acta 1047, 233-238.

Hemer, S., Konrad, C., Spiliotis, M., Koziol, U., Schaack, D., Förster, S., Gelmedin, V., Stadelmann, B., Dandekar, T., Hemphill, A., Brehm, K., 2014. Host insulin stimulates Echinococcus multilocularis insulin signalling pathways and larval development. BMC Biol. 12, 1-22.

Hertzel, A. V, Hellberg, K., Reynolds, J.M., Kruse, A.C., Juhlmann, B.E., Smith, A.J., Sanders, M.A., Ohlendorf, D.H., Suttles, J., Bernlohr, D.A., 2009. Identification and characterization of a small molecule inhibitor of Fatty Acid binding proteins. J. Med. Chem. 52, 6024-6031.

Hodsdon, M.E., Cistola, D.P., 1997. Ligand binding alters the backbone mobility of intestinal fatty acid-binding protein as monitored by $15 \mathrm{~N}$ NMR relaxation and $1 \mathrm{H}$ exchange. Biochemistry 36, 2278-2290. 
Holcman, B., Heath, D.D., 1997. The early stages of Echinococcus granulosus development. Acta Trop. 64, 5-17.

Hsu, K., Storch, J., 1996. Fatty Acid Transfer from Liver and Intestinal Fatty Acid-binding Proteins to Membranes Occurs by Different Mechanisms. J. Biol. Chem. 271, 1331713323.

Hubbard, S.J., 1998. The structural aspects of limited proteolysis of native proteins. Biochim. Biophys. Acta 1382, 191-206.

Irabedra, P., Roig, C., 2007. Estimación del impacto económico de la equinococosis quística en el Cono Sur (Argentina, Brasil, Chile y Uruguay). Organización de las Naciones Unidas para la Alimentacion y la Agricultura, Oficina Regional para America Latina y el Caribe.

Jabbar, A., Jenkins, D.J., Crawford, S., Walduck, A.K., Gauci, C.G., Lightowlers, M.W., 2011. Oncospheral penetration glands are the source of the EG95 vaccine antigen against cystic hydatid disease. Parasitology 138, 89-99.

Jakobsson, E., Alvite, G., Bergfors, T., Esteves, A., Kleywegt, G.J., 2003. The crystal structure of Echinococcus granulosus fatty-acid-binding protein 1. Biochim. Biophys. Acta $1649,40-50$.

Jin, X., Lu, L., Su, H., Lou, Z., Wang, F., Zheng, Y., Xu, G.-T., 2013. Comparative analysis of known miRNAs across platyhelminths. FEBS J. 280, 3944-3951.

Kim, S.H., Bae, Y.A., Yang, H.J., Shin, J.H., Diaz-Camacho, S.P., Nawa, Y., Kang, I., Kong, Y., 2012. Structural and Binding Properties of Two Paralogous Fatty Acid Binding Proteins of Taenia solium Metacestode. PLoS Negl. Trop. Dis. 6, e1868.

Kleinfeld, A., Storch, J., 1993. Transfer of long-chain fluorescent fatty acids between small and large unilamellar vesicles. Biochemistry 32, 2053-2061.

Koziol, U., Krohne, G., Brehm, K., 2013. Anatomy and development of the larval nervous system in Echinococcus multilocularis. Front. Zool. 10, 1-17.

Koziol, U., Rauschendorfer, T., Zanon Rodríguez, L., Krohne, G., Brehm, K., 2014. The unique stem cell system of the immortal larva of the human parasite Echinococcus multilocularis. Evodevo 5, 1-23.

Kralisch, S., Ebert, T., Lossner, U., Jessnitzer, B., Stumvoll, M., Fasshauer, M., 2014. Adipocyte fatty acid-binding protein is released from adipocytes by a non-conventional mechanism. Int. J. Obes. 38, 1251-1254.

Kralisch, S., Fasshauer, M., 2012. Adipocyte fatty acid binding protein: a novel adipokine involved in the pathogenesis of metabolic and vascular disease? Diabetologia 56, 10 21.

Laemmli, U.K., 1970. Cleavage of structural proteins during the assembly of the head of bacteriophage T4. Nature 227, 680-685.

Larrieu, E., Herrero, E., Mujica, G., Labanchi, J.L., Araya, D., Grizmado, C., Calabro, A., Talmon, G., Ruesta, G., Perez, A., Gatti, A., Santillán, G., Cabrera, M., Arezzo, M., 
Seleiman, M., Cavagión, L., Cachau, M.G., Alvarez Rojas, C. a., Gino, L., Gauci, C.G., Heath, D.D., Lamberti, R., Lightowlers, M.W., 2013. Pilot field trial of the EG95 vaccine against ovine cystic echinococcosis in Rio Negro, Argentina: Early impact and preliminary data. Acta Trop. 127, 143-151.

Larrieu, E., Zanini, F., 2012. Critical analysis of cystic echinococcosis control programs and praziquantel use in South America, 1974-2010. Rev. Panam. Salud Pública 31, 81-87.

Lee, E.-G., Kim, S.-H., Bae, Y.-A., Chung, J.-Y., Suh, M., Na, B.-K., Kim, T.-S., Kang, I., Ma, L., Kong, Y., 2007. A hydrophobic ligand-binding protein of the Taenia solium metacestode mediates uptake of the host lipid: implication for the maintenance of parasitic cellular homeostasis. Proteomics 7, 4016-4030.

Lowe, J.B., Sacchettini, J.C., Laposata, M., McQuillan, J.J., Gordon, J.I., 1987. Expression of Rat Intestinal Fatty Acid-binding Protein in Escherichia coli. J. Biol. Chem. 262, 59315937.

Lymbery, A.J., Jenkins, E.J., Schurer, J.M., Thompson, R.C.A., 2015. Echinococcus canadensis, E. borealis, and E. intermedius. What's in a name? Trends Parasitol. 31, 23-29.

Martínez, C., Paredes, R., Stock, R.P., Saralegui, A., Andreu, M., Cabezón, C., Ehrlich, R., Galanti, N., 2005. Cellular organization and appearance of differentiated structures in developing stages of the parasitic platyhelminth Echinococcus granulosus. J. Cell. Biochem. 94, 327-335.

Massey, J.B., Bick, D.H., Pownall, H.J., 1997. Spontaneous transfer of monoacyl amphiphiles between lipid and protein surfaces. Biophys. J. 72, 1732-1743.

Maté, S.M., Brenner, R.R., Ves-Losada, a., 2004. Phosphatidyl choline fatty acid remodeling in the hepatic cell nuclei. Prostaglandins, Leukot. Essent. Fat. Acids 70, 49-57.

Maule, A.G., Marks, N.J. (Eds.), 2006. Parasitic Flatworms: Molecular Biology, Biochemistry, Immunology and Physiology. CABI.

McDermott, L., Kennedy, M.W., McManus, D.P., Bradley, J.E., Cooper, A., Storch, J., 2002. How helminth lipid-binding proteins offload their ligands to membranes: differential mechanisms of fatty acid transfer by the ABA-1 polyprotein allergen and Ov-FAR-1 proteins of nematodes and Sj-FABPc of schistosomes. Biochemistry 41, 6706-6713.

McDermott, L., Moore, J., Brass, A., Price, N.C., Kelly, S.M., Cooper, A., Kennedy, M.W., 2001. Mutagenic and chemical modification of the ABA-1 allergen of the nematode Ascaris: consequences for structure and lipid binding properties. Biochemistry 40 , 9918-9926.

McManus, D.P., 2013. Current status of the genetics and molecular taxonomy of Echinococcus species. Parasitology 140, 1617-1623.

McManus, D.P., Gray, D.J., Zhang, W., Yang, Y., 2012. Diagnosis, treatment, and management of echinococcosis. BMJ 344, e3866. 
Mizukami, C., Spiliotis, M., Gottstein, B., Yagi, K., Katakura, K., Oku, Y., 2010. Gene silencing in Echinococcus multilocularis protoscoleces using RNA interference. Parasitol. Int. 59, 647-652.

Mohammadzadeh, T., Sadjjadi, S.M., Rahimi, H., 2014. Still and Moving Image Evidences for Mating of Echinococcus granulosus Reared in Culture Media. Iran. J. Parasitol. 9, 129133.

Moral, M. (Ed.), 2012. Enfermedades infecciosas. Hidatidosis. Guía para el Equipo de Salud Nro 11. Ministerio de Salud de la Nación- República Argentina.

Moro, P., Schantz, P.M., 2009. Echinococcosis: a review. Int. J. Infect. Dis. 13, 125-133.

Morrison, W., Smith, L., 1964. Preparation of fatty acid methyl esters and dimethylacetals from lipids with boron fluoride-methanol. J. Lipid Res. 5, 600-608.

Moser, D., Tendler, M., Griffiths, G., Klinkert, M.Q., 1991. A 14-kDa Schistosoma mansoni polypeptide is homologous to a gene family of fatty acid binding proteins. J. Biol. Chem. 266, 8447-8454.

Mustonen, P., Virtanen, J.A., Somerharju, P.J., Kinnunen, P.K., 1987. Binding of cytochrome $\mathrm{C}$ to liposomes as revealed by the quenching of fluorescence from pyrene-labeled phospholipids. Biochemistry 26, 2991-2997.

Nakao, M., Lavikainen, A., Yanagida, T., Ito, A., 2013. Phylogenetic systematics of the genus Echinococcus (Cestoda: Taeniidae). Int. J. Parasitol. 43, 1017-1029.

Nicolson, G.L., 2014. The Fluid-Mosaic Model of Membrane Structure: still relevant to understanding the structure, function and dynamics of biological membranes after more than 40 years. Biochim. Biophys. Acta 1838, 1451-1466.

Obal, G., Ramos, A., Silva, V., Lima, A., Batthyany, C., Bessio, M., Ferreira, F., Salinas, G., Ferreira, A.M., 2012. Characterisation of the native lipid moiety of Echinococcus granulosus antigen B. PLoS Negl. Trop. Dis. 6, e1642.

Olsen, O.W., 1977a. Parasitología animal: El parasitismo y los protozoos, Volumen 1. Aedos.

Olsen, O.W., 1977b. Parasitología animal: Platelmintos, acantocéfalos y nematelmintos, Volumen 2. Aedos.

Parada, G.E., Munita, R., Cerda, C. a, Gysling, K., 2014. A comprehensive survey of noncanonical splice sites in the human transcriptome. Nucleic Acids Res. 42, 1-15.

Paulino, M., Esteves, A., Vega, M., Tabares, G., Ehrlich, R., Tapia, O., 1998. Modelling a 3D structure for EgDf1 from Echinococcus granulosus: putative epitopes, phosphorylation motifs and ligand. J. Comput. Aided. Mol. Des. 12, 351-360.

Plenefisch, J., Xiao, H., Mei, B., Geng, J., Komuniecki, P.R., Komuniecki, R., 2000. Secretion of a novel class of iFABPs in nematodes: Coordinate use of the Ascaris/Caenorhabditis model systems. Mol. Biochem. Parasitol. 105, 223-236. 
Pórfido, J.L., Alvite, G., Silva, V., Kennedy, M.W., Esteves, A., Córsico, B., 2012. Direct Interaction between EgFABP1, a Fatty Acid Binding Protein from Echinococcus granulosus, and Phospholipid Membranes. PLoS Negl. Trop. Dis. 6, e1893.

Prior, A., Jones, J.T., Blok, V.C., Beauchamp, J., McDermott, L., Cooper, A., Kennedy, M.W., 2001. A surface-associated retinol- and fatty acid-binding protein (Gp-FAR-1) from the potato cyst nematode Globodera pallida: lipid binding activities, structural analysis and expression pattern. Biochem. J. 356, 387-394.

Rigano, R., Buttari, B., Profumo, E., Ortona, E., Delunardo, F., Margutti, P., Mattei, V., Teggi, A., Sorice, M., Siracusano, A., 2007. Echinococcus granulosus Antigen B Impairs Human Dendritic Cell Differentiation and Polarizes Immature Dendritic Cell Maturation towards a Th2 Cell Response. Infect. Immun. 75, 1667-1678.

Rodríguez-Pérez, J., Rodríguez-Medina, J.R., García-Blanco, M.A., Hillyer, G. V, 1992. Fasciola hepatica: molecular cloning, nucleotide sequence, and expression of a gene encoding a polypeptide homologous to a Schistosoma mansoni fatty acid-binding protein. Exp. Parasitol. 74, 400-407.

Sambrook, J., Russell, D., 2001. Molecular Cloning: A Laboratory Manual, Third Edition. Cold Spring Harbor Laboratory Press.

Schaap, F.G., van der Vusse, G.J., Glatz, J.F.C., 2002. Evolution of the family of intracellular lipid binding proteins in vertebrates. Mol. Cell. Biochem. 239, 69-77.

Schmid, F., 1997. Optical spectroscopy to characterize protein conformation and conformational change: 4. Circular dichroism, in: Creighton (Ed.), Protein Structure: A Practical Approach. Oxford University Press, New York, pp. 261-297.

Schroeder, F., Jolly, C., Cho, T., Frolov, A., 1998. Fatty acid binding protein isoforms: structure and function. Chem. Phys. Lipids 92, 1-25.

Sessler, R.J., Noy, N., 2005. A ligand-activated nuclear localization signal in cellular retinoic acid binding protein-II. Mol. Cell 18, 343-353.

Sheth, N., Roca, X., Hastings, M.L., Roeder, T., Krainer, A.R., Sachidanandam, R., 2006. Comprehensive splice-site analysis using comparative genomics. Nucleic Acids Res. 34, 3955-3967.

Silva-Álvarez, V., Folle, A.M., Ramos, A.L., Zamarreño, F., Costabel, M.D., García-Zepeda, E., Salinas, G., Córsico, B., Ferreira, A.M., 2015a. Echinococcus granulosus antigen B: A Hydrophobic Ligand Binding Protein at the host - parasite interface. Prostaglandins Leukot. Essent. Fat. Acids 93, 17-23.

Silva-Álvarez, V., Franchini, G.R., Pórfido, J.L., Kennedy, M.W., Ferreira, A.M., Córsico, B., 2015b. Lipid-Free Antigen B Subunits from Echinococcus granulosus: Oligomerization, Ligand Binding, and Membrane Interaction Properties. PLoS Negl. Trop. Dis. 9, e0003552.

Smathers, R.L., Petersen, D.R., 2011. The human fatty acid-binding protein family: evolutionary divergences and functions. Hum. Genomics 5, 170-191. 
Smyth, J.D., McManus, D.P. (Eds.), 2007. The Physiology and Biochemistry of Cestodes. Cambridge University Press.

Spiliotis, M., Brehm, K., 2009. Axenic in vitro cultivation of Echinococcus multilocularis metacestode vesicles and the generation of primary cell cultures. Methods Mol. Biol. 470, 245-62.

Spiliotis, M., Mizukami, C., Oku, Y., Kiss, F., Brehm, K., Gottstein, B., 2010. Echinococcus multilocularis primary cells: Improved isolation, small-scale cultivation and RNA interference. Mol. Biochem. Parasitol. 174, 83-87.

Spiliotis, M., Tappe, D., Sesterhenn, L., Brehm, K., 2004. Long-term in vitro cultivation of Echinococcus multilocularis metacestodes under axenic conditions. Parasitol. Res. 92, 430-432.

Storch, J., Bass, N.M., 1990. Transfer of fluorescent fatty acids from liver and heart fatty acid-binding proteins to model membranes. J. Biol. Chem. 265, 7827-7831.

Storch, J., Bass, N.M., Kleinfeld, A.M., 1989. Studies of the fatty acid-binding site of rat liver fatty acid-binding protein using fluorescent fatty acids. J. Biol. Chem. 264, 8708-8713.

Storch, J., Córsico, B., 2008. The emerging functions and mechanisms of mammalian fatty acid-binding proteins. Annu. Rev. Nutr. 28, 73-95.

Storch, J., McDermott, L., 2009. Structural and functional analysis of fatty acid-binding proteins. J. Lipid Res. 50, S126-S131.

Storch, J., Thumser, A., 2010. Tissue-specific functions in the fatty acid-binding protein family. J. Biol. Chem. 285, 32679-32683.

Tan, N., Shaw, N., Vinckenbosch, N., 2002. Selective cooperation between fatty acid binding proteins and peroxisome proliferator-activated receptors in regulating transcription. Mol. Cell. Biol. 22, 5114-5127.

Thompson, R.C.A., Jenkins, D.J., 2014. Echinococcus as a model system : biology and epidemiology. Int. J. Parasitol. 44, 865-877.

Thompson, R.C.A., Lymbery, A.J., 1988. The nature, extent and significance of variation within the genus Echinococcus. Adv. Parasitol. 27, 209-258.

Thompson, R.C.A., McManus, D.P., 2002. Towards a taxonomic revision of the genus Echinococcus. Trends Parasitol. 18, 452-457.

Torgerson, P.R., Keller, K., Magnotta, M., Ragland, N., 2010. The global burden of alveolar echinococcosis. PLoS Negl. Trop. Dis. 4, e722.

Tsai, I.J., Zarowiecki, M., Holroyd, N., Garciarrubio, A., Sanchez-Flores, A., Brooks, K.L., Tracey, A., Bobes, R.J., Fragoso, G., Sciutto, E., Aslett, M., Beasley, H., Bennett, H.M., Cai, J., Camicia, F., Clark, R., Cucher, M., De Silva, N., Day, T.A., Deplazes, P., Estrada, K., Fernandez, C., Holland, P.W.H., Hou, J., Hu, S., Huckvale, T., Hung, S.S., Kamenetzky, L., Keane, J.A., Kiss, F., Koziol, U., Lambert, O., Liu, K., Luo, X., Luo, Y., Macchiaroli, N., Nichol, S., Paps, J., Parkinson, J., Pouchkina-Stantcheva, N., Riddiford, N., Rosenzvit, M., Salinas, G., Wasmuth, J.D., Zamanian, M., Zheng, Y., Cai, X., 
Soberón, X., Olson, P.D., Laclette, J.P., Brehm, K., Berriman, M., 2013. The genomes of four tapeworm species reveal adaptations to parasitism. Nature 496, 57-63.

Uversky, V., 1993. Use of fast protein size-exclusion liquid chromatography to study the unfolding of proteins which denature through the molten globule. Biochemistry 32 , 13288-13298.

Velkov, T., Lim, M., Capuano, B., Prankerd, R., 2008. A protocol for the combined subfractionation and delipidation of lipid binding proteins using hydrophobic interaction chromatography. J. Chromatogr. B 867, 238-246.

Wang, Y., Law, W.-K., Hu, J.-S., Lin, H.-Q., Ip, T.-M., Wan, D.C.-C., 2014. Discovery of FDAapproved drugs as inhibitors of fatty acid binding protein 4 using molecular docking screening. J. Chem. Inf. Model. 54, 3046-3050.

Wang, Y., Lin, H.-Q., Law, W.-K., Liang, W.-C., Zhang, J.-F., Hu, J.-S., Ip, T.-M., Waye, M.M.-Y., Wan, D.C.-C., 2015. Pimozide, a Novel Fatty Acid Binding Protein 4 Inhibitor, Promotes Adipogenesis of 3T3-L1 Cells by Activating PPARY. ACS Chem. Neurosci. 6, 211-218.

WHO, 2015. WHO | World Health Organization [WWW Document]. URL http://www.who.int/neglected_diseases/diseases/en/

Zheng, H., Zhang, W., Zhang, L., Zhang, Z., Li, J., Lu, G., Zhu, Y., Wang, Y., Huang, Y., Liu, J., Kang, H., Chen, J., Wang, L., Chen, A., Yu, S., Gao, Z., Jin, L., Gu, W., Wang, Z., Zhao, L., Shi, B., Wen, H., Lin, R., Jones, M.K., Brejova, B., Vinar, T., Zhao, G., McManus, D.P., Chen, Z., Zhou, Y., Wang, S., 2013. The genome of the hydatid tapeworm Echinococcus granulosus. Nat. Genet. 45, 1168-1177.

Zheng, Y., 2013. Phylogenetic analysis of the Argonaute protein family in platyhelminths. Mol. Phylogenet. Evol. 66, 1050-1054.

Zheng, Y., Blair, D., Bradley, J.E., 2013. Phyletic distribution of fatty acid-binding protein genes. PLoS One 8, e77636.

Zimmerman, A.W., Veerkamp, J.H., 2002. New insights into the structure and function of fatty acid-binding proteins. Cell. Mol. Life Sci. 59, 1096-1116. 